UNIVERSIDADE DE SÃO PAULO $\square$

FACULDADE DE FILOSOFIA, LETRAS E CIÊNCIAS HUMANAS DEPARTAMENTO DE ANTROPOLOGIA $\square$

PROGRAMA DE PÓS-GRADUAÇÃO EM ANTROPOLOGIA SOCIAL

MILENA MATEUZI CARMO

MARGEM ADENTRO:

políticas sociais, sujeitos e resistências na zona sul de São

Paulo

VERSÃO CORRIGIDA

v.1

São Paulo

2017 


\author{
UNIVERSIDADE DE SÃO PAULO \\ FACULDADE DE FILOSOFIA, LETRAS E CIÊNCIAS HUMANAS \\ DEPARTAMENTO DE ANTROPOLOGIA \\ PROGRAMA DE PÓS-GRADUAÇÃO EM ANTROPOLOGIA SOCIAL
}

\title{
MARGEM ADENTRO: \\ políticas sociais, sujeitos e resistências na zona sul de São
}

Paulo

\author{
Milena Mateuzi Carmo
}

Dissertação apresentada ao Programa de Pós Graduação em Antropologia Social do Departamento de Antropologia da Faculdade de Filosofia, Letras e Ciências Humanas da Universidade de São Paulo para obtenção do título de Mestre em Antropologia, sob a orientação da Prof.a Dr.a Laura Moutinho.

De acordo:

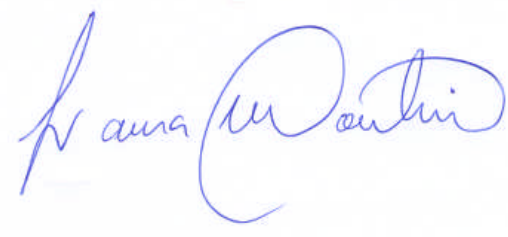

VERSÃO CORRIGIDA

v.1

São Paulo

2017 
Autorizo a reprodução e divulgação total ou parcial deste trabalho, por qualquer meio convencional ou eletrônico, para fins de estudo e pesquisa, desde que citada a fonte.

Catalogação na Publicação

Serviço de Biblioteca e Documentação

Faculdade de Filosofia, Letras e Ciências Humanas da Universidade de São Paulo

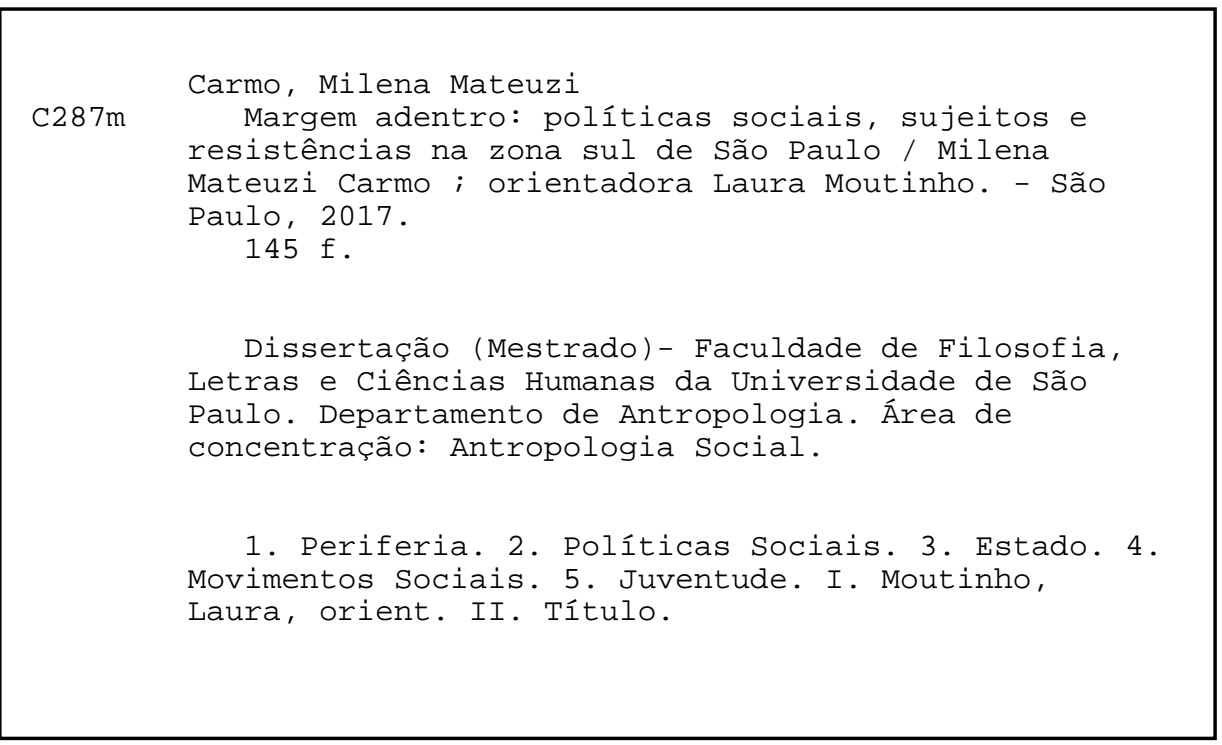


Para Célia Mateuzi Carmo e Ubirajara de Souza Carmo 


\section{Agradecimentos}

Momentos de agradecer são sempre bonitos e difíceis. Bonitos porque olhamos para dentro e achamos coisas que pensávamos que eram nossas, mas que na verdade foram deixadas por pessoas que passaram por nossa vida. E difícil, porque, muitas vezes, as palavras não são suficientes para expressar a beleza dessas coisas e dos encontros que as trouxeram.

Como este trabalho não trata apenas de pesquisar um "tema" relevante para mim, mas sim de trajetórias e percursos dos quais também faço parte, as pessoas que agradeço aqui vem de longe, vem do profundo do que penso, faço e sou hoje.

Primeiro gostaria de agradecer ao povo da zona sul. Chão de "terra fértil", como diz a talentosa escritora Jenyffer Nascimento, onde brota vida por todo canto. Lugar onde fiz minha morada e onde encontrei sentido para minha luta.

Começo com as pessoas com quem vive no CDHEP, Centro de Direitos Humanos e Educação Popular. Certamente as linhas que seguem são resultado do barro que amaçamos juntos! Alessandra, agradeço por trazer seus ventos de liberdade e criação, por ter me apresentado toda efervescência do feminismo periférico da zona sul; Andrea, com quem não canso de me surpreender com tamanha empatia e simplicidade, agradeço por ter me mostrado todos os caminhos sinuosos das políticas sociais com suas violências e resistências; Fernanda Laender, por ter me ensinado a escutar e olhar para além do que é fácil de ver no outro; Mariana Brito agradeço pela delicadeza e partilha; Dennys Knowles, pela disponibilidade e alegria; Marcio Bhering, pelas discussões tão produtivas e pelo samba; Carolina Diniz, pela serenidade e companheirismo; José Cícero pela caminhada de tanto tempo; e Rodolfo Valente, pela crítica e aprendizado.

Ao povo do Comitê Juventude e Resistência pelo entusiasmo, esperança e persistência, principalmente a Vitor Silva, Maria Edjane Alves e Fernando Ferrari que partilharam suas histórias e refletiram junto comigo sobre este trabalho.

Agradeço imensamente às pessoas do MSE Capão II: Sulamita Assunção e Elaine Lima, Maurício Alves, Antonia Sivanilda e Luís Fernando Silva pela confiança, partilha e por estarmos juntos na luta.

Agradeço também às amigas e amigos que encontrei neste meu retorno à universidade. Sobretudo à Thais Tiriba, Tulio Bucchioni e Janaina Gomes, pela imediata afinidade pessoal, intelectual e política. Vocês foram fundamentais para que este retorno fosse mais doce.

Agradeço também a cada pessoa do grupo de orientandas e orientandos, incluindo os "agregados", da Profa. Laura Moutinho, por estarmos juntos tratando de questões tão 
complexas com profundidade e, ao mesmo tempo, com leveza: Valéria Alves, Pedro Lopes, Marcio Zamboni, Rafael Noleto, Luiza Ferreira Lima, Waldor Botero, Maria Isabel Zanzotti, Gleicy Mailly Silva, Denise Pimenta e Gabriela Araujo.

Agradeço também aos mestrandos que em 2014 iniciaram comigo esta jornada pelo sentimento de cumplicidade, principalmente para Izabela Nalio Ramos e Fernanda Kalyanne Martins. E aos pesquisadores com quem cursei a disciplina Antropologia da Guerra, oferecida também pela professora Laura Moutinho, pela possibilidade de participar de um processo de profunda reflexão acadêmica, engajamento e entrega pessoal.

Sou imensamente grata aos professores que participaram de minha banca de qualificação, Gabriel de Santis Feltran e Ana Lúcia Pastore Schritzmeyer, pelas orientações valiosas que reordenaram o curso deste trabalho. À Ana Lúcia agradeço ainda pela enorme aprendizado não apenas como aluna da disciplina Antropologia do Direito, mas sobretudo como monitora de sua disciplina na graduação.

Agradeço também aos professores do PPGAS, sobretudo Ana Claudia Duarte Rocha Marques e Fernanda Arêas Peixoto, cujas disciplinas foram fundamentais para meu processo como aprendiz de antropóloga. Sou grata também pelo apoio e atenção dedicados pelas funcionárias e funcionários do programa, sobretudo à Soraya Gebara.

Tenho que agradecer também aos meus antigos e eternos amigos junto aos quais passei as dores e delícias da graduação. Foi ao lado dessas pessoas que pude assentar as bases não só da construção de meu conhecimento, mas também de minha visão de mundo. Pessoas estas que até hoje fazem parte da minha vida no trabalho e na luta: Uvanderson Vitor da Silva, Márcio Macedo, Flávio Francisco e Muryatan Barbosa. Foi na sala 111 (nossa piada interna) e a partir do programa Dez vezes Dez, coordenado pelo Prof. Antônio Sérgio Alfredo Guimarães, que comecei a me aprofundar na discussão racial alicerçando as bases para o compromisso de uma vida.

E não poderia deixar de agradecer ao LISA (Laboratório de Imagem e Som em Antropologia), sobretudo à Profa. Sylvia Cauby Novaes, minha orientadora na iniciação científica, e à querida Mariana Vanzolini, por todo apoio e amizade. Agradeço também à Miriam Lifchitz Moreira Leite (in memoriam) por ter me dado a possibilidade de navegar por seus materiais sobre os viajantes do século XIX.

Também gostaria de agradecer ao Prof. Charles Klein, Portland State University, pela oportunidade única de participar da pesquisa Entendendo a Mobilidade e a Precariedade: Modos de Vida Emergentes e Subjetividades Políticas entre a Nova Classe Média do Brasil. 
Agradeço ainda ao apoio fundamental da CAPES, sem o qual este trabalho não seria realizado.

Gostaria também de agradecer à tantas mulheres maravilhosas, ainda não mencionadas aqui, que me ensinam sobre empoderamento, liberdade e sororidade: Maria Lúcia da Silva, Jussara Dias, Carmen Faustino, Daniela Braga, Fabiana Ivo, Dandara Gomes, Cristiane Oliveira, Taisa Souza, Eliane Weinfurter, Cristiane Uchoa, Luana Oliveira e Karina Poli.

Sou imensamente grata à Léa Tosold, um destes encontros lindos da vida, pela leitura cuidadosa e generosa de meu trabalho, além da imensa contribuição em cada sugestão. Espero que este seja a primeira de muitas partilhas!

Palavras me faltam para agradecer à Laura Moutinho pelo acolhimento, compreensão e apoio, mesmo antes de meu ingresso no mestrado, até o último dia deste processo.

E por fim, ao meu amado companheiro, Edson Luis da Silva, que esteve comigo durante toda esta jornada, dando-me apoio e dividindo comigo a intensa carga emocional envolvida no decurso deste trabalho. 


\title{
RESUMO
}

Esta pesquisa tem por objetivo observar a execução das políticas sociais no cotidiano da periferia da zona sul da cidade de São Paulo a partir de práticas e discursos protagonizados pelos sujeitos nelas envolvidos: profissionais, "usuários" e ativistas. Entendo Estado como uma forma de organização de poder que se impõe hierarquicamente e se reproduz cotidianamente nas "margens": esquadrinhando e controlando territórios, categorizando e segmentando a população, normatizando e burocratizando relações e sujeitos. Busco, a partir da observação do trânsito de sujeitos, discursos e práticas entre serviços públicos e articulações locais, apresentar como estes podem tanto reafirmar a forma de poder estatal, quanto resistir a ela. Tal resistência é alimentada por discursos que se constroem localmente a partir da mobilização de identidades que articulam marcadores sociais da diferença sobretudo raça, classe e gênero - e a ideia de sofrimento gerada pela reprodução de violências institucionais ligadas a estes marcadores

\section{PALAVRAS-CHAVE}

Periferia; Políticas Sociais; Estado; Movimentos Sociais; Juventude

\begin{abstract}
The objective of this study is to analyze the implementation of social policies in everyday life in the Zona Sul of São Paulo through considering the conflicting practices and discourses of those involved in their execution - professionals, service recipients, and activists. I conceive the State as a form of the organization of power that imposes and reproduces its hierarchies in the "margins" by delineating and controlling space, categorizing and ordering the population, and normalizing and bureaucratizing social relations and subjects. I seek, through observing the movement of people, discourses and practices within public services and their local articulation, to demonstrate how they both reaffirm and resist state power. This resistance is supported through locally constructed discourses that mobilize identities articulated around social markers of difference - above all, race, class and gender - and the idea of the suffering generated by the reproduction of institutional violence linked to these categories.
\end{abstract}

\section{KEYWORDS}

Outskirts; Social Politics; State; Social Movements; Youth 


\section{Sumário}

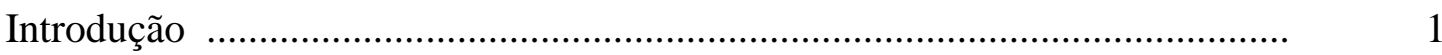

Capítulo 1 - A sul de perto ......................................................................... 12

Caminhos da sul ............................................................................. 12

Caminhos institucionais .................................................................. 17

Coletivos, sujeitos e resistências ........................................................ 31

Capítulo 2 - Vozes sobre a periferia .......................................................... 43

Zona sul, uma periferia de São Paulo .................................................. 44

Zona sul, dados e taxas ................................................................. $\quad 57$

Capítulo 3 - Estado, violência e resistência ................................................... 61

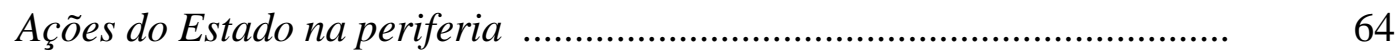

As políticas sociais e a assistência social ............................................. 73

Capítulo 4 - Os serviços de medida socioeducativa em meio aberto $\quad$.............. $\quad 83$

A política …................................................................................... 83

O MSE Capão II ...................................................................... 89

O PIA, plano de atendimento individual .............................................. 93

Sujeitos perigosos, serviços perigosos ……......................................... $\quad 98$

Tensões, resistências e horizontalidade .................................................. 103

Capítulo 5 - O Plano Juventude Viva e ativismo na zona sul ....................... 108

Juventude, uma categoria …........................................................ 111

A política de juventude ........................................................................ 117

O Plano Juventude Viva na zona sul ................................................. 120

O Comitê Juventude e Resistência e a luta contra o "genocídio de jovens negros e pobres da periferia ".............................................................. 129

Considerações finais ............................................................................. 137

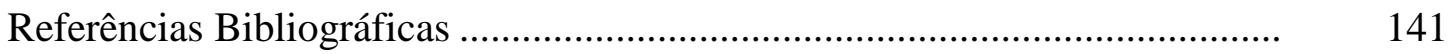


Afirmar que uma vida pode ser lesada, por exemplo, ou que pode ser perdida, destruída ou sistematicamente negligenciada até a morte é sublinhar não somente a finitude de uma vida (o fato de que a morte é certa), mas também sua precariedade (porque a vida requer que várias condições sociais e econômicas sejam mantidas para ser mantida como uma vida). A precariedade implica viver socialmente, isto é, o fato de que a vida de alguém está sempre, de alguma forma, nas mãos do outro. Isso implica estarmos expostos não somente àqueles que conhecemos, mas também àqueles que não conhecemos, isto é, dependemos das pessoas que conhecemos, das que conhecemos superficialmente e das que desconhecemos totalmente. Reciprocamente, isso significa que nos são impingidas a exposição e a dependência dos outros, que, em sua maioria, permanecem anônimos. Essas não são necessariamente relações de amor ou sequer de cuidado, mas constituem obrigações para com os outros, cuja maioria não conhecemos nem sabemos que nome tem e que podem ou não ter traços de familiaridade com um sentido estabelecido de quem somos "nós".

- Judith Butler em Quadros de guerra 


\section{Introdução}

Em outras palavras, tirar a vida, o imperativo da morte, só é admissível, no sistema de biopoder, se tende não à vitória sobre os adversários políticos, mas à eliminação do perigo biológico e ao fortalecimento, diretamente ligado a essa eliminação, da própria espécie ou da raça. A raça, o racismo, é a condição de aceitabilidade de tirar a vida numa sociedade de normalização. Quando vocês tem uma sociedade de normalização, quando vocês tem um poder que é, ao menos em toda a superfície e em primeira instância, em primeira linha, um biopoder, pois bem, o racismo é indispensável como condição para poder tirar a vida de alguém, para poder tirar a vida dos outros. A função assassina do Estado só pode ser assegurada, desde que o Estado funcione no modo do biopoder, pelo racismo.

Michael Foucault, Em defesa da sociedade

Quando comecei a escrever as primeiras linhas deste trabalho, fui tomada por uma inquietação: para quem escreveria? Produziria um estudo estritamente acadêmico, voltado para os antropólogos que refletem sobre periferia, Estado, violência e outros temas aqui relacionados ou me preocuparia com meu ativismo e com os sujeitos que não são apenas interlocutores do meu campo, mas, acima de tudo, pessoas com quem atuo lado a lado? Essas perguntas surgiram como se fosse possível escolher um desses caminhos de escrita em detrimento do outro. Conforme produzia, fui percebendo que ocorria exatamente o contrário. Em vez de fragmentação, notava que ia elaborando e integrando as minhas experiências acadêmica, profissional e de luta: no texto, em mim e no meu próprio ativismo.

Atuo no campo das políticas sociais para adolescentes e jovens há cerca de treze anos. Ao longo desse tempo, passei por lugares bem diferentes, assumindo também posições distintas: ONGs, movimentos sociais, governo municipal, programas federais e coletivos autônomos ora me reconhecendo como gestora de políticas sociais ou profissional de ONG, ora me identificando como ativista. Além disso, sempre estive em interface com a academia, não só por minha formação em ciências sociais, mas, sobretudo, porque a produção acadêmica me dava acesso a um tipo de conhecimento e a uma forma de olhar a prática que permitia problematizar constantemente tais lugares, ações e discursos. Esse trânsito me proporcionou a 
construção de uma visão específica desse campo.

Assim, as páginas que seguem trazem fragmentos do que eu poderia chamar de uma "autoetnografia", ou, utilizando os termos de Marilyn Strathern, de uma "autoantropologia" (Strathern, 2014), uma vez que também sou um desses sujeitos do meu trabalho de campo. Mas esta "autoetnografia", longe de ser uma narrativa individual, é uma visão ou uma interpretação de percursos e reflexões feitas coletivamente, junto com sujeitos que estão tanto no ativismo, quanto na acadêmica. Mesmo porque esses mundos sempre estiveram, ainda que com tensões, em relação. Desse modo, mais especificamente, objetivo nesta dissertação, por intermédio da mobilização de recursos diversos, realizar uma etnografia das "margens" do Estado, percorrendo suas bordas por meio do contato com pessoas com quem convivi, explorando minhas memórias, lendo e inquirindo instituições, políticas sociais, ativistas, profissionais etc.

Portanto, trago neste trabalho encontros, reflexões e percursos que vivi na zona sul da cidade, mais especificamente nos distritos Capão Redondo, Jardim Ângela, Jardim São Luís e Campo Limpo: experiência adquirida a partir da circulação por um amplo e heterogêneo campo composto por instituições públicas e privadas que, aqui, estou chamando de "margens" do Estado (Das; Poole, 2004).

Busco problematizar a ideia de "ausência do Estado" nas periferias. Noção esta ainda muito recorrente quando se trata em descrever territórios periféricos, sobretudo no que se refere ao fornecimento estatal de adequadas e suficientes condições de infraestrutura urbana e acesso à direitos sociais básicos: saúde, educação, assistência social, etc. Muitos trabalhos que se debruçam sobre o tema, demonstraram que de uma total ausência de direitos, que caracterizou a ocupação destes territórios durante décadas, houve significativas melhorias no que se refere à infraestrutura urbana e políticas sociais, principalmente a partir da década de 1980. Melhorias estas conquistadas principalmente pela atuação de movimentos sociais nas periferias da cidade (Sarti, 1996; Feltran, 2008; Kowarik, 2009).

No entanto esta presença do Estado não tem como efeito apenas a ampliação da garantia de direitos, mas sim uma multiplicação de mecanismos de normatização, repressão e controle das populações destes territórios, em especial a partir da década de 1990 (Feltran, 2008).

Desse modo, a hipótese que procurei sustentar aqui é a de que o Estado, desde então, está muito presente na periferia: presença esta que está longe de significar a integral garantia dos direitos sociais. Meu argumento é o de que o Estado se afirma na periferia no sentido de reprimir, normatizar e controlar a vida da população concentrada em territórios segregados: seja por meio da ação violenta da polícia, seja por meio do cotidiano das políticas sociais. Em 
outras palavras, o Estado contribui ativamente para a produção da "periferia", inclusive por intermédio de políticas sociais.

Devo ressaltar também que, neste trabalho, periferia não é entendida de maneira uniforme e homogênea. Há quase três décadas, uma ampla produção acadêmica vem demonstrando a diversidade não apenas em termos econômicos e sociais dos territórios periféricos, mas também sua multiplicidade no que se refere a espaços de representações, práticas e interações sociais moldando formas de vida e experiências vividas. Como, já afirmava Eunice Durham: "periferia é fenômeno uniforme e diverso" (Durham, 1986).

E não se trata de ignorar os processos macroetruturais que produzem as periferias, mas sim ver de perto tal produção. "Em suma, na etnografia em favelas e periferias da cidade tem sido possível reconhecer impactos causados tanto pelas mudanças na institucionalidade política quanto no mercado de trabalho, na família, na religiosidade, no consumo e no projeto de mobilidade social. Em meio a essas transformações, entretanto, a desigualdade entre pobres e ricos atravessa as três últimas décadas intocada." (Feltran; 2010, p. 208) Por esta razão o termo periferia ainda faz sentido, mas talvez seja mais adequado falar em periferias, como muitos autores já apontam (Marques, 2010).

Assim como periferia não é vista como homogênia, o Estado não é entendido aqui como uma entidade ou um bloco monolítico, cujas fronteiras são impermeáveis e rigidamente delimitadas, mas sim como uma forma de organização do poder que se impõe hierarquicamente, visando categorizar, normatizar e controlar grupos, sujeitos e relações (Hoffman, 2011).

Neste trabalho, trato dos sujeitos, das instituições e dos movimentos sociais que atuam no interior ou em interface com as políticas sociais. Mais especificamente, analiso algumas políticas de assistência social, de crianças e adolescentes e juventude. Assim, dito de outro modo, minha hipótese é a de que essas políticas estão estreitamente imbricadas com o campo de "gestão social" na periferia, contribuindo, inclusive, para a sua constituição. Tal campo é composto por um grande número de instituições privadas, as Organizações "não Governamentais" (ONGs), que executam essas políticas. Concomitantemente, procuro também refletir sobre como muitas dessas instituições se constituíram a partir de movimentos sociais que, aos poucos, foram absorvendo uma lógica de funcionamento do Estado.

Percorrendo minha própria experiência nessas "margens", pretendo analisar como o Estado tende a se impor sob múltiplas formas. Uma imposição que, acredito, efetiva-se de 
forma autoritária e violenta. Nesse sentido, os efeitos dessa imposição também são múltiplos: não somente a opressão, o sofrimento social e a normatização do "público-alvo", mas também a promoção parcial de direitos entre moradores e a fragmentação dos movimentos sociais.

Contudo, tal processo não se realiza, é preciso destacar, sem resistência, bem como reprodução, dos sujeitos envolvidos nesse campo. Ao lado de ativistas, profissionais das políticas sociais e pessoas "atendidas" pelos serviços públicos, fui percebendo práticas e discursos diversos. Fui aprendendo a reconhecer, a partir das ações dos sujeitos, como essa imposição opera no cotidiano e, também, as formas de resistir à violência do Estado (Butler, 2015) são forjadas. Aqui, entendendo resistências como práticas e discursos que se propõem a desestabilizar a forma hierarquizada e normatizadora de organização do poder.

O campo de minha pesquisa é então composto por instituições, coletivos e sujeitos com os quais passei a me envolver desde 2011, ano em que fui para a zona sul trabalhar em uma ONG chamada CDHEP - Centro de Direitos Humanos e Educação Popular do Campo Limpo $^{1}$. A partir desse trabalho, fui conhecendo uma rede composta por atores diversos: instituições, muito diferentes entre si no que se refere a princípios políticos, que executam as políticas sociais; secretarias, coordenadorias, supervisões e serviços que compõem a estrutura do Estado; movimentos sociais e coletivos locais que estão constantemente se multiplicando e reinventando-se; ativistas normalmente ligados a instituições, movimentos e coletivos; e sujeitos "atendidos" pelas políticas sociais. Apresentarei tais atores ao longo do trabalho.

Passei a conviver com profissionais e gestores das políticas sociais, ativistas, sujeitos “atendidos" pelas políticas sociais, fazendo parte, junto com eles, de um campo dinâmico de produção de discursos, construção de trajetórias e de identidades e reprodução da violência. Foi a partir desse campo que construí minha pesquisa.

Sendo assim, não busco realizar uma etnografia de uma política ou instituição específica. Minha aposta metodológica foi a de seguir o movimento desses sujeitos, ou seja, um trânsito percorrido horizontalmente no que entendo que são as margens do Estado que, por sua vez, impõe-se verticalmente. Em outras palavras, meu foco não foi o de analisar o surgimento da política de juventude ou os conflitos políticos a partir dos quais se originou o Plano Juventude $\mathrm{Viva}^{2}$, mas sim entender como este aterrissa no território da zona sul e observar os conflitos que eclodem a partir de sua implementação. Tais conflitos falam sobre os efeitos, reproduções e resistências desta imposição, onde os sujeitos estão em permanente

\footnotetext{
${ }^{1}$ A ONG será apresentada em detalhes adiante.

${ }^{2}$ Plano criado pelo governo federal que tem por fim prevenir homicídios de jovens, negros, moradores da periferia. O plano será tratado no capítulo 4.
} 
movimento, sendo reproduzindo, seja reagindo a este poder.

Três lugares foram fundamentais para realização da pesquisa. O primeiro foi o próprio CDHEP, onde transitavam diversos representantes de instituições e das políticas sociais, ativistas e articulações locais da zona sul. Sujeitos, majoritariamente jovens moradores da região, que estão sempre em "ação" desenvolvendo. A partir do CDHEP tive então contato com os demais espaços: o Serviço de Medida Socioeducativa - MSE Capão II - e o Comitê Juventude e Resistência.

O MSE Capão II é um serviço de medida socioeducativa voltado para jovens em "conflito com a lei” que estão cumprindo liberdade assistida (LA) e prestação de serviços à comunidade (PSC). Medida socioeducativas são aplicadas a pessoas com menos de 18 anos que cometeram algum "ato infracional”, como apresentarei no capítulo três desta dissertação. Trata-se de uma política da assistência social, orientada pelas políticas de crianças e adolescentes e executada por instituições da sociedade civil. No caso do Capão II, pela Associação Jardim Comercial e Adjacências. Tal instituição foi criada a partir de um importante movimento social da região, cuja atuação se deu principalmente nas décadas de 1970 e 1980. Hoje tem, como atividade principal, a execução de diversos serviços de assistência social.

Fui me aproximando deste MSE mais especificamente devido à circulação dos "técnicos" desse serviço em outros espaços e atividades na região. Jovens psicólogos, educadores, assistentes sociais que estão em busca de articulações locais para fortalecer e ampliar "as possibilidades de atendimento" junto aos jovens em medida socioeducativa e suas famílias.

Já o Comitê Juventude e Resistência é um coletivo formado por ativistas locais, cuja origem deu-se a partir do comitê intersetorial (composto por representantes do governo e da sociedade civil) para a implementação do Plano Juventude Viva. Por divergências políticas, um grupo de ativistas se desvinculou do Juventude Viva e formou o Comitê Juventude e Resistência, que começou a desenvolver diversas ações na zona sul tendo em vista denunciar a violência do Estado, definida em termos de "racismo de Estado" (Foucault, 2002), contribuindo para fortalecer a "luta" contra o denominado "genocídio" ou "extermínio" da juventude ou população "negra, indígena e pobre". Essas categorias (ou formas de nomeação) ainda estão em disputa no campo, mas se referem às altas taxas de homicídio de jovens negros na região, apresentadas no capítulo dois.

Considerei importante trazer o Comitê Juventude e Resistência para esta análise, ao lado do MSE Capão II, porque o campo de atuação de ambos é justamente nas "margens" do Estado: tencionando e recriando discursos e práticas, tendo em vista "desnaturalizar a 
violência do Estado". Além disso, o Comitê se aproximou do MSE Capão II, desenvolvendo atividades conjuntas tanto com os profissionais, que estavam começando também a integrá-lo, quanto com familiares dos jovens em medidas socioeducativas, que estavam iniciando sua participação nas atividades "políticas" da região, para além do atendimento.

Assim, realizei uma etnografia das ações de certos sujeitos nesses dois lugares que, embora tenham naturezas diferentes, foram constituídos a partir do que estou chamando de "margens do Estado". O MSE Capão II está totalmente incorporado na estrutura burocrática que envolve assistência social e judiciário, sem poder "escapar" dessa condição. Já o Comitê Juventude e Resistência foi gerado a partir dos conflitos que surgiram na implementação de uma política de juventude e, embora dela tenha se desvinculado, sua interface com o Estado será contínua, justamente porque sua "luta" é contra a violência do Estado.

A aproximação desses dois lugares, a partir das relações e trajetórias dos sujeitos que neles atuam, foi fundamental para entender as possibilidades de construção, agências e resistências no cotidiano. Portanto, acompanho a trajetória e a circulação das pessoas que fazem esse campo se movimentar. São elas: Andrea Arruda, 45 anos, psicóloga, negra autodeclarada, professora universitária, moradora da região com mais de 20 anos de trabalho em serviços públicos e de ativismo, que hoje também faz parte do Comitê Juventude e Resistência; Márcio Bhering, 36 anos, pedagogo, negro autodeclarado, morador da região que já trabalhou em algumas ONGs com atuação local, inclusive no CDHEP, e que hoje integra também o Comitê Juventude e Resistência; Vitor Silva, 21 anos, negro autodeclarado, graduando em ciências sociais, morador do município vizinho, Embu das Artes, ativista local e integrante do Comitê Juventude e Resistência; Fernando Ferrari, 36 anos, branco autodeclarado, morador da região, ativista local com forte atuação no "movimento de cultura periférica" e integrante do Comitê Juventude e Resistência; Sulamita Assunção, 30 anos, negra autodeclarada, psicóloga, moradora da zona oeste, embora tenha nascido na região, "técnica" do MSE Capão II e uma das responsáveis, juntamente com Elaine, pela atuação "mais politizada" do serviço; Elaine Lima, 33 anos, negra autodeclarada, pedagoga, moradora da região, também "técnica" do MSE e ativista local; dentre outras pessoas que vão aparecendo ao longo do trabalho. Fui conhecendo-as ao longo dos anos, desde que entrei na zona sul. Relações de trabalho, ativismo e amizade que cada vez mais se misturam e aprofundam. Por isso sou também um sujeito de minha pesquisa.

Junto com essas pessoas, problematizamo-nos sobre práticas e discursos que eram naturalizados entre nós: perguntamo-nos sobre nossas trajetórias, sobre nosso ativismo e, continuamente, sobre o trabalho que realizávamos. Esse processo de reflexão no campo com 
vistas a uma atuação profissional e política é uma das bases desta pesquisa, além da observação de documentos normativos das políticas sociais, das estruturas governamentais para implementação das políticas sociais e da leitura da bibliografia sobre as questões pertinentes ao campo - periferia, Estado, políticas sociais. Em outras palavras, todo esse material (o humano e o materializado em papéis) pavimentou o campo de observação da dinâmica acerca da forma ou das várias formas pelas quais "o Estado" se impõe nas margens e de como os sujeitos se situam nelas, reforçando ou resistindo a essa forma de poder.

No primeiro capítulo deste trabalho, irei apresentar os percursos na zona sul, incluindo minha própria trajetória: instituições, sujeitos, os caminhos que fizeram parte dessa experiência na região e que alimentaram a construção de meu olhar sobre ela. A narrativa desses percursos expressa uma dinâmica cotidiana intensamente marcada pela ação dos sujeitos no sentido de construir discursos sobre a periferia (ao mesmo tempo que os confronta) e sobre si, seguindo um forte impulso para agir contra a desigualdade. Enfim, o objetivo foi mostrar minha entrada na região e como o campo da "gestão social" se organiza.

Já no segundo capítulo, percorro um conjunto de narrativas acadêmicas e locais sobre a zona sul. Tais narrativas contribuem para a construção e a disseminação de representações e discursos sobre a periferia: depoimentos e documentários sobre a região; bibliografia acadêmica sobre a periferia; matérias produzidas pela mídia (grande mídia e veículos alternativos) e, por fim, dados estatísticos. O interesse desse capítulo é notar como os discursos sobre a periferia, mais especificamente sobre a zona sul, tendem a ressaltar os efeitos da desigualdade, a pobreza e a violência, especialmente aqueles que são produzidos "fora" dela, contribuindo assim para a intensificação do estigma da periferia. Concomitantemente, vê-se um esforço de ativistas em construir um discurso sobre si que não deixa de revelar os efeitos da desigualdade, mas busca produzir uma narrativa positivada de se viver na periferia, que mobiliza "luta" e identidade, sobretudo, racial e "periférica".

No capítulo 3, irei expor e analisar o que a pesquisa realizada para esta dissertação e minha experiência no cenário da zona sul revelam com relação à presença do Estado. Como adiantei anteriormente, exploro neste capítulo a hipótese de que o Estado está presente na periferia como forma de organização de poder que se manifesta de várias maneiras, dentre elas as que partem das políticas sociais. Observando seus efeitos, concluo que a ampliação dessas políticas se constitui em um campo de ações que representa um avanço, embora precário e insuficiente, no que se refere ao acesso a direitos sociais. No entanto, pretendo ressaltar que tal acesso não deixa de ser uma tentativa de controle e normatização de seu "público-alvo", os sujeitos "potencialmente perigosos" e suas famílias. Além disso, a forma 
como essas políticas foram implementadas, isto é, sendo executadas por instituições da sociedade civil, provocou sua incorporação marginal dos atores políticos da periferia na política (Feltran, 2010), um enfraquecimento na capacidade de luta dos movimentos sociais,, bem como sua crescente burocratização, redefinindo as relações com a população em termos de "técnicos" das políticas sociais e "atendidos".

No capítulo 4, aproximo-me ainda um pouco mais da "ponta" de um serviço público. Trago para o texto o Serviço de Medida Socioeducativa Capão II e seus sujeitos. Recupero os documentos normativos e legais que sustentam essa política, bem como suas contradições. Assim, busquei observar no cotidiano como os "técnicos" vivem tais contradições lidando com a estrutura burocrática e tentando encontrar outros caminhos para o "atendimento" de jovens. No texto, procuro também apresentar a forma como vejo os discursos locais de identidade atravessando essa estrutura da política, desestabilizando as relações entre "técnicos e atendidos" previstas pela burocracia. A ideia de uma identidade partilhada de pertencimento local, racial e de gênero coloca em questão, segundo defendo, os distanciamentos hierarquizados estabelecidos pela política.

Por fim, no capítulo 5, convido o leitor a conhecer o Comitê Juventude e Resistência e a implementação do Plano Juventude Viva. Aqui, apresento uma reflexão feita junto com os sujeitos envolvidos sobre o processo de implementação dessa política. A fragilidade em relação ao objetivo que se propunha - que era a "prevenção" de homicídios de jovens negros e pobres -, bem como as ações que reforçavam uma "individualização" desse problema, recolocando mais uma vez, a responsabilidade, segundo minha hipótese, sobre os próprios jovens e suas famílias. Desse processo, surgem ativistas que fortalecem um discurso sobre "genocídio da população negra e pobre" e intensificam suas ações nas "margens" deste Estado. Apontando, assim, como demonstrou o trabalho etnográfico, para a emergência cada vez mais expressiva de um talvez "novo" ativismo, que se diferencia das lutas tradicionais por direitos e participação na esfera do Estado. Um Estado que passa a ser denunciado como o violador de direitos contra o qual é necessário se proteger: "Nós por nós!" é a expressão que representa tais movimentos.

Lembro-me de que, quando decidi retornar à universidade, depois de quase dez anos em que me dediquei exclusivamente ao trabalho e ao ativismo, uma das primeiras leituras que fiz foi a "Aula de 17 de Março de 1976" do livro Em Defesa da sociedade, de Michel Foucault, na disciplina Antropologia das Emoções, ministrada pela professora Laura Moutinho, na Universidade de São Paulo. Nesse texto, o autor propõe a discussão do biopoder, isto é, a forma de poder que emerge com o Estado contemporâneo que visa "fazer viver", ou seja, 
proteger a vida da espécie, da população, controlando-a e normatizando-a. No entanto, esse poder que protege a vida também "deixa morrer", e isso só é possível, afirma Foucault, a partir do racismo do Estado. Para ele:

(...) tirar a vida, o imperativo da morte, só é admissível, no sistema de biopoder, se tende não à vitória sobre os adversários políticos, mas à eliminação do perigo biológico e ao fortalecimento, diretamente ligado a essa eliminação, da própria espécie ou da raça. A raça, o racismo, é a condição de aceitabilidade de tirar a vida numa sociedade de normatização. (Foucault, 2002, p. 305-306)

A discussão realizada por Foucault foi muito importante para dar sentido ao que eu vivia no meu campo de atuação, pois oferecia uma forma de entender situações de violação de direitos, omissão e violência direta praticada pelo poder público cotidianamente na periferia: precarização de políticas sociais; descaso e humilhação da população em equipamentos públicos; violência policial etc. Além disso, oferecia uma interpretação sobre o Estado evidenciando a violência e o racismo que naquele momento nós, ativistas, ainda não dispúnhamos. Isto é, nos ofereceu a possibilidade de enquadrar a violência do Estado como racismo institucionalizado.

Por tal razão, essa foi uma das leituras fundamentais para o grupo de pessoas com quem atuava no CDHEP. Ela nos ofereceu uma interpretação alternativa de Estado que não a ideia deste como uma entidade promotora de direitos, mas sim como uma forma de organização de poder que controla, normatiza e extermina aqueles que oferecem risco à "população".

Essa leitura coletiva num campo de ativismo e trabalho reforça a potência da aproximação desses âmbitos de ativismo com o conhecimento acadêmico e com a universidade, sugerindo caminhos de fortalecimento mútuo.

Assim, volto à questão que abre esta introdução sobre os caminhos de escrita possíveis da presente dissertação. A ideia de que se tratavam de caminhos distintos, academia e ativismo, surge talvez pelo lugar que a universidade, sobretudo a pública, assume neste país: extremamente elitizada e praticamente inacessível para muitos dos sujeitos que estão comigo no ativismo. A questão aqui não seria a de incompatibilidade entre produção acadêmica e ativismo. O problema são as condições em que essas diferentes práticas, reflexões e produções de discursos se dão: em um contexto extremamente desigual, em que as pessoas que vivenciam as contradições e as delícias de se viver na periferia pouco acessam as universidades públicas. 
Espero que este trabalho importe não só para um campo de produção de conhecimento acadêmico sobre periferia, Estado e políticas sociais, mas que sirva como um elemento de reflexão e fortalecimento de nossa "luta" contra as desigualdades, violências e injustiças sociais. 


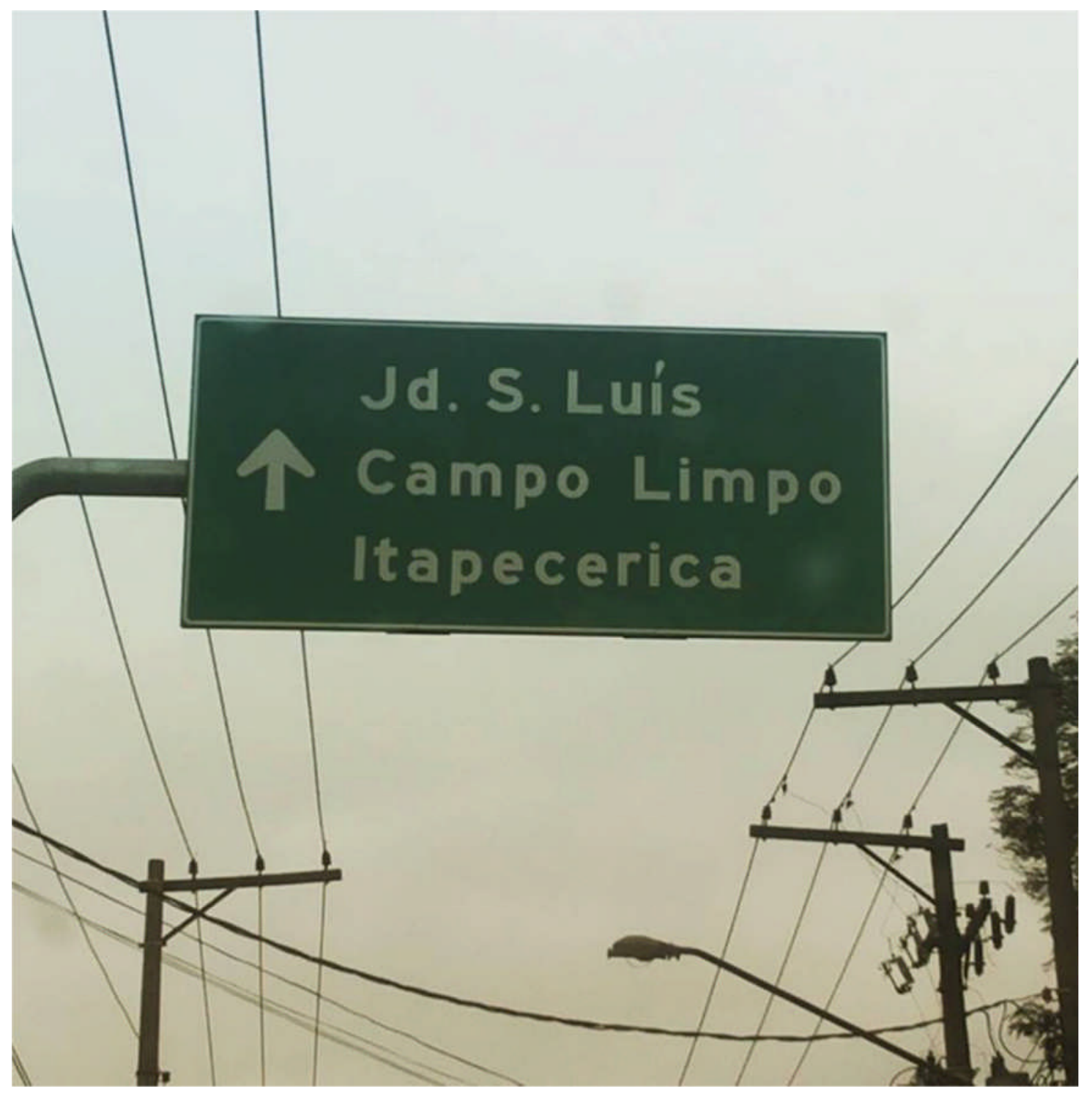




\section{Capítulo 1 - A sul de perto}

Da ponte pra cá, antes de tudo é uma escola Minha meta é dez, nove e meio nem rola

Meio ponto a ver, hum e morre um Meio certo não existe, truta, o ditado é comum Ser humano perfeito, não tem mesmo não

Procurada viva ou morta a perfeição

Errare humano est, grego ou troiano?

Latim, tanto faz pra mim: Fi"de baiano

Mas se tiver calor, quentão no verão

Cê quer dá um rolê no Capão daquele jeito

Mas perde a linha fácil, veste a carapuça Esquece estes defeitos no seu jaco de camurça

Jardim Rosana, Treze, Tremembé

Santa Tereza, Valo Velho e Dom José

Parque Chácara, Lídia, Vaz

Fundão, muita treta pra Vinícius de Morais

Não adianta querer, tem que ser, tem que pá

O mundo é diferente da ponte pra cá

- Da ponte pra cá, Racionais MC's

\section{Caminhos da Sul}

Você pode sair ou chegar à "sul" por diversos caminhos. Sul é como as pessoas que moram ou possuem alguma intimidade com a região dos distritos do Jardim Ângela, Jardim São Luís, Campo Limpo, Capão Redondo e Vila Andrade a chamam quando a referência é a cidade de São Paulo. Trata-se na verdade de um pedaço da zona sul do município. Um canto à sudoeste, circunscrito pelos municípios de Embu das Artes, Itapecerica da Serra e EmbuGuaçu, pela represa Guarapiranga, pela marginal Pinheiros e pelo distrito do Morumbi, já pertencente à zona oeste. É uma região que de fato está nas margens do que administrativamente se define como território da cidade. E percorrer essas "fronteiras" é ver, sentir e ouvir o que elas têm a nos dizer sobre as histórias desse lugar, suas contradições e heterogeneidade, opressão e agência, violências e resistências. 


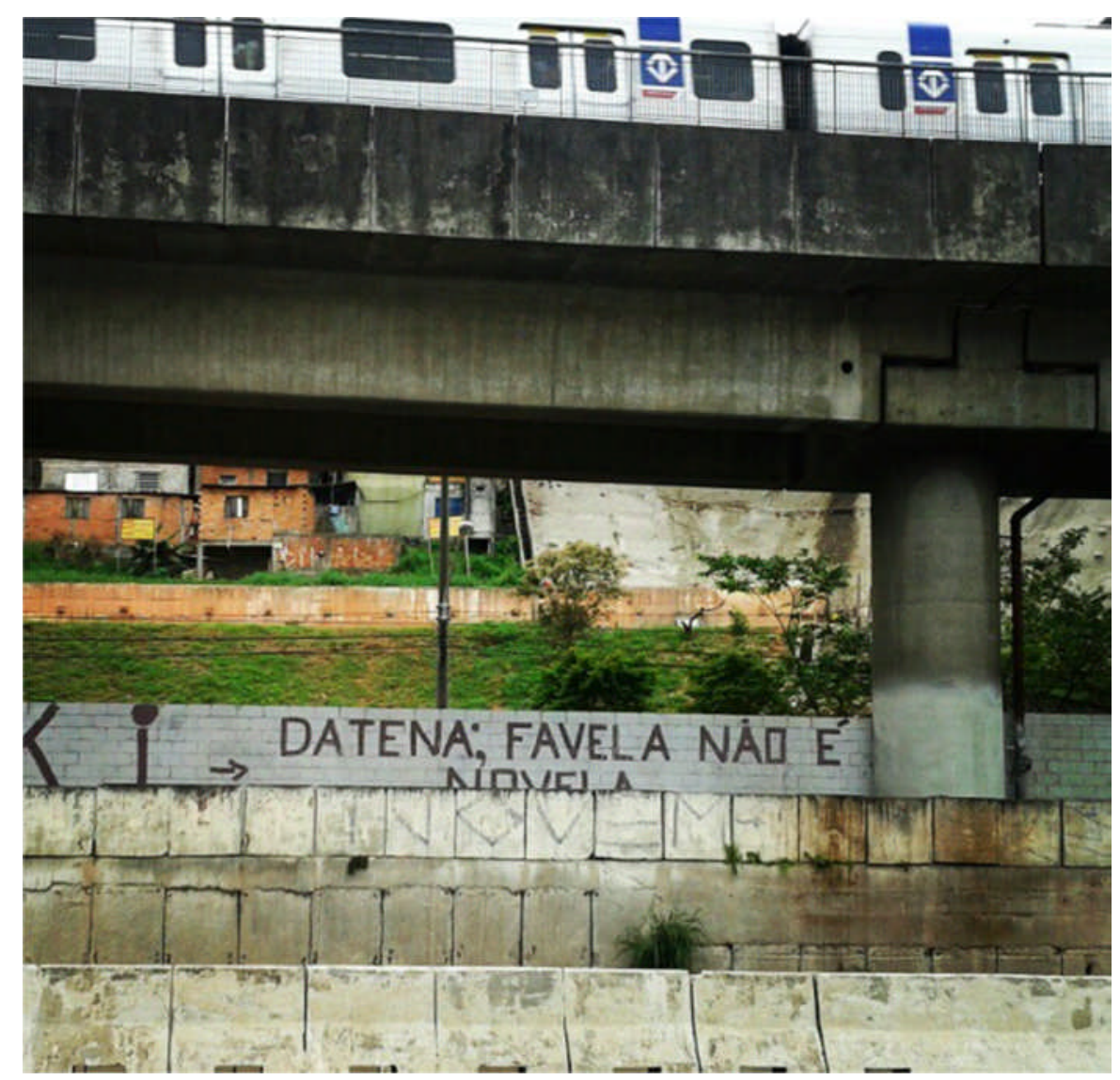

Linha Lilás do Metrô - Foto: José Cícero

Um dos trajetos possíveis é o metrô-trem. O metrô, linha Lilás, que vai do Capão Redondo para o Largo Treze, em Santo Amaro, e o trem que percorre a marginal do rio Pinheiros do Grajaú (distrito da zona sul mais à sudeste) ao município de Osasco. Esse é o caminho que a esmagadora maioria de trabalhadoras e trabalhadores da região utiliza para acessar as regiões mais centrais da cidade todos os dias. É também o mais rápido, se comparado ao ônibus e também ao carro, embora esteja longe de ser o mais confortável. Nos horários de pico, milhares de pessoas chegam à estação Capão Redondo espremidas nos ônibus superlotados vindos de bairros mais afastados, como Jardim Vera Cruz e Favela do Bananal, às margens da Guarapiranga, ou de bairros de Embu das Artes e de Itapecerica.

Essa parte da sul é uma das regiões mais populosas da cidade, sem contar a população dos outros municípios limítrofes que a utilizam como via de acesso ao centro diariamente. Todo esse povo se afunila nos corredores, nas plataformas e nos vagões ao som das palavras de ordem repetidas como mantras nas estações do metrô: "não corra nas escadas", "não corra nas plataformas", "não permaneça nas portas", "não fume" etc. Contudo, em meio à aparente ordem e disciplina, na ultrajante condição do transporte público por essas bandas sempre tem aqueles que a subvertem correndo, gritando, permanecendo nas portas ou brigando. 
A subversão ainda pode ser vista pela janela de quem viaja. O metrô parte e, logo de cara, quem está ao lado esquerdo do vagão verá um enorme grafite dos Racionais $\mathrm{MC}$ 's ${ }^{3}$ bem na entrada do Jardim Ipê, bairro pobre da região. A paisagem vai sendo preenchida por favelas, que ocupam pequenos morros e vales, intercaladas por condomínios fechados que vão ficando cada vez mais luxuosos conforme se aproxima a estação de metrô Giovanni Gronchi a medida que as favelas, curiosamente, ficam mais precárias. Mas, se ao longo deste trecho você viajar do lado direito do vagão, a paisagem será bem diferente: vai observar um bairro popular, formado por casas individuais de alvenaria bem-acabadas com garagens e até condomínios de classe média. Um shopping center, vários supermercados e, inclusive, um Sesc recém-inaugurado, o Campo Limpo. Do metrô, dá para ver a heterogeneidade da periferia.

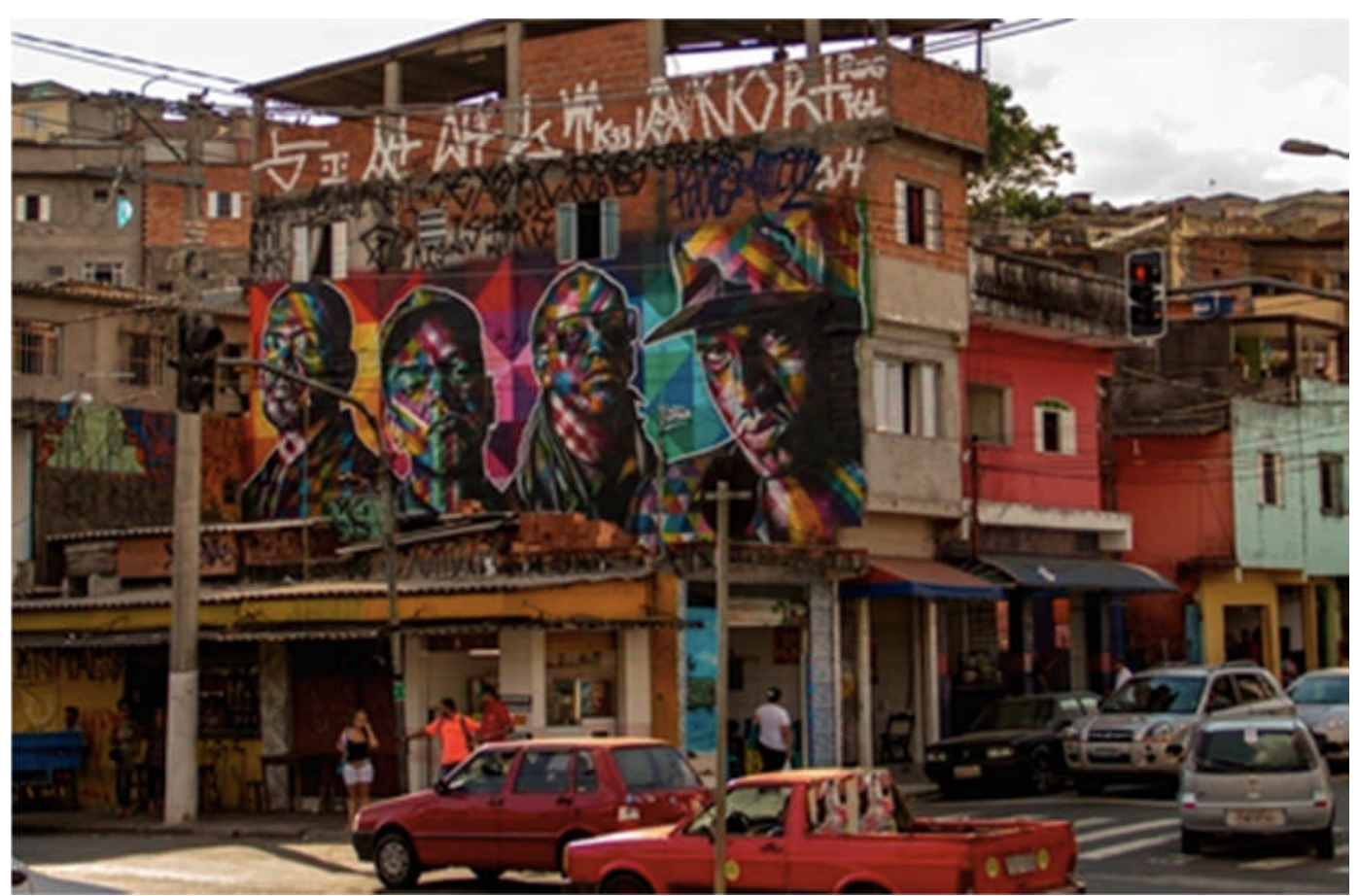

Grafite dos Racionais MC's feito pelo artista Eduardo Kobra na entrada do Jardim Ipê, próximo à estação de metrô do Capão Redondo

Ao chegar então à estação Giovanni Gronchi, a contradição fica evidentemente mais acentuada. Estamos no início da avenida Giovanni, próximos ao distrito Vila Andrade. Aqui, em vez da heterogeneidade da periferia, vê-se polarização. Prédios luxuosos se erguem ao lado de barracos de madeira. Faço esse caminho há mais de cinco anos e ainda me indigno.

\footnotetext{
${ }^{3}$ Fundado em 1988 na zona sul de São Paulo pelos MC's Mano Brown, Edi Rock, Ice Blue e DJ KL Jay, o grupo Racionais MC's é considerado o mais relevante e influente do país. Com acidez e teor político contundente, o grupo sempre tratou de temas como violência policial, preconceito racial, criminalidade e miséria, embora seja muito criticado por suas letras "machistas".
} 
Fico imaginando o que pensam e sentem as milhares de trabalhadoras e trabalhadores que passam por ali diariamente: indignação também? Raiva? Indiferença? Tristeza? Revolta?

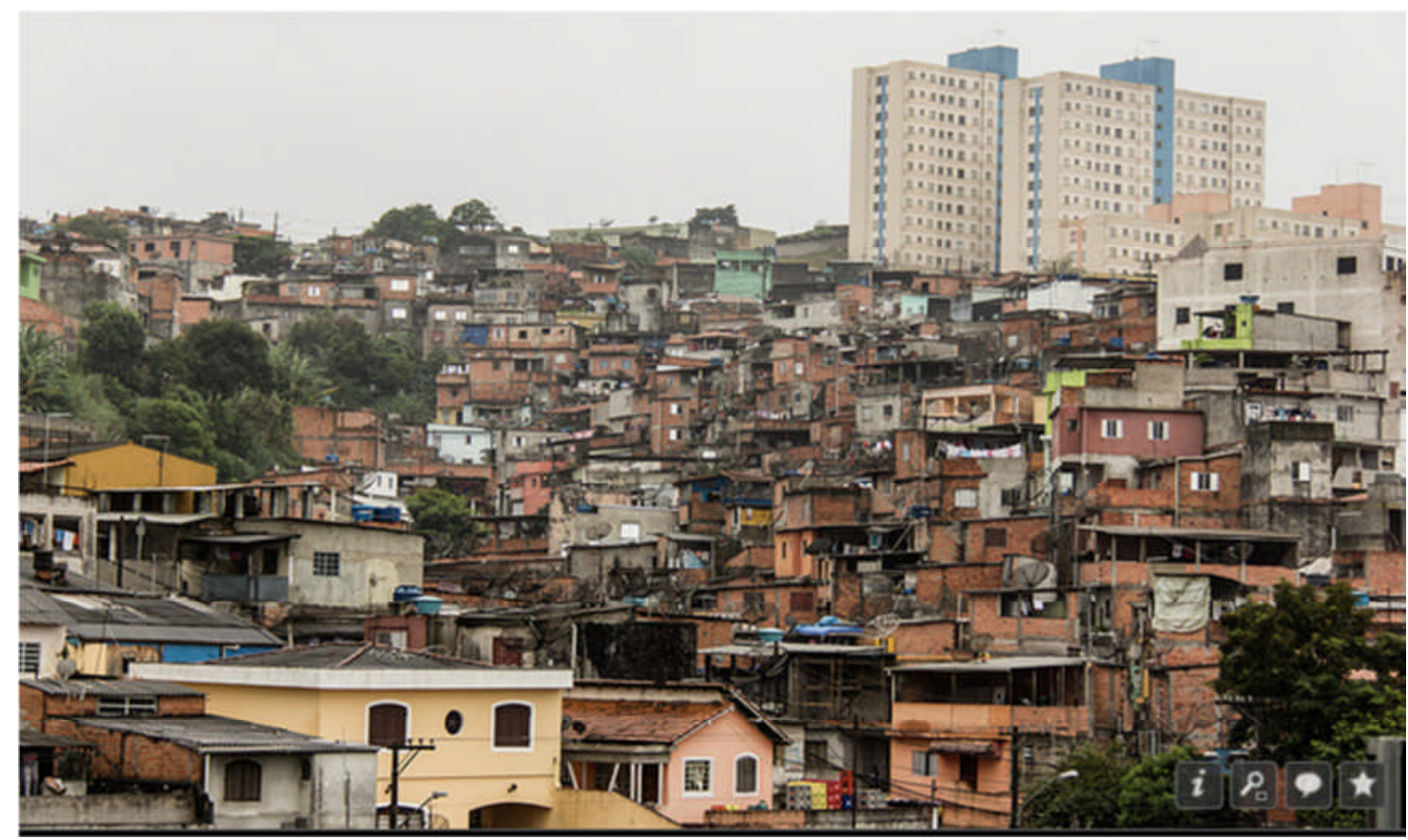

Vila das Belezas, vista do metrô

Subir a av. Giovanni Gronchi sentido zona oeste pode ser uma experiência em que a indignação faz-se queimar um pouco mais forte. Eu mesma, acostumada com as contradições dali, diversas vezes já me senti desorientada. Uma dessas vezes foi quando, buscando caminhos alternativos por dentro do bairro para chegar à Vila das Belezas, seguia por uma rua muito arborizada e cheia de mansões. Então, quando virei uma rua à esquerda, fui surpreendida por uma enorme favela.

A Giovanni é toda preenchida por prédios, condomínios e casas de luxo que se erguem com toda a sua imponência aos transeuntes, sobretudo nos trechos mais altos da avenida. Dá até certa vertigem ao olhar para cima! No entanto, tal imponência não esconde as frestas, os vãos por onde se vê relances de casas de tijolo à vista que, se observadas de perto, dão acesso à paisagem de imensas favelas que se espalham como rizomas pela região. Trata-se das favelas do Jardim Ingá e Jardim São Roque, além da Paraisópolis, com quase 43 mil moradores. 


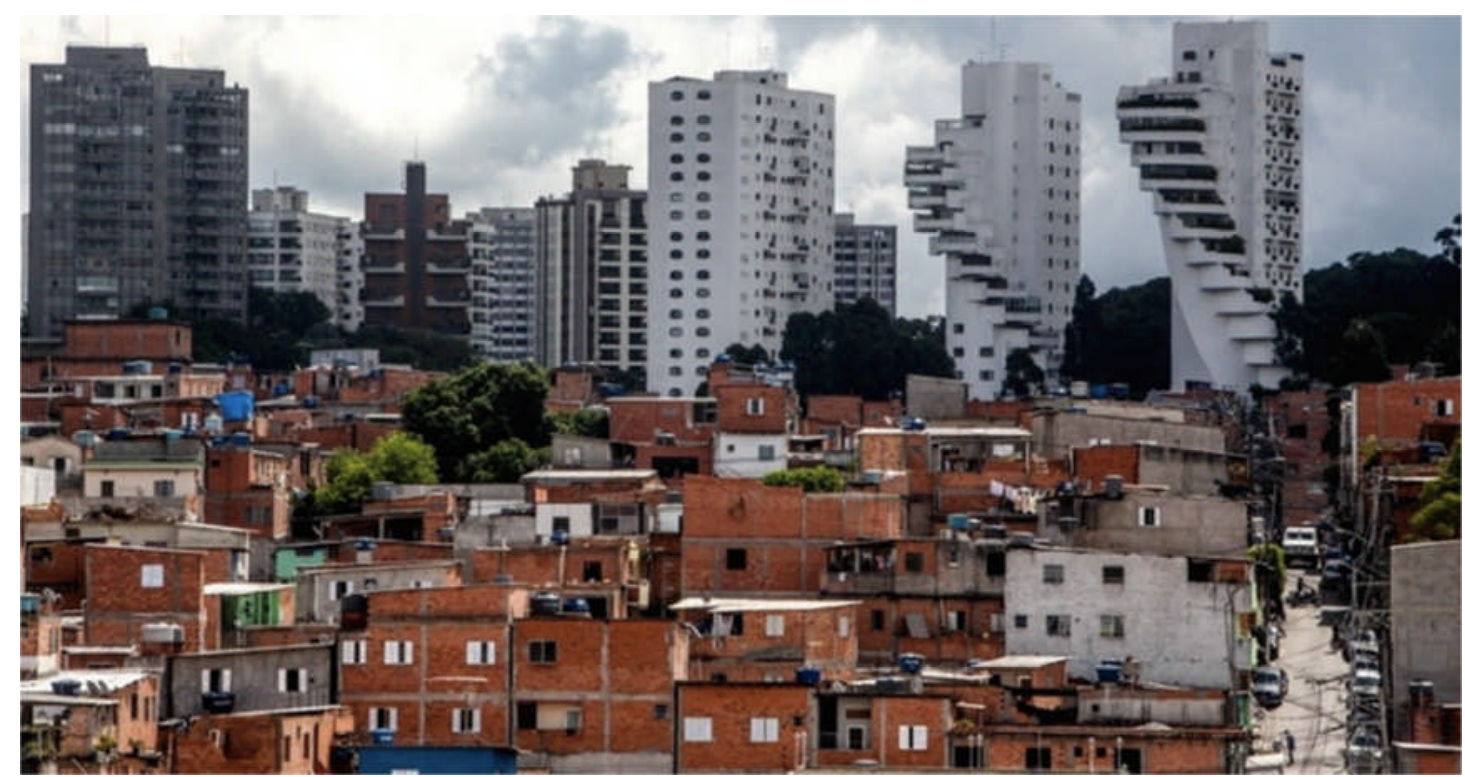

Favela Paraisópolis, com prédios da av. Giovani Gronchi ao fundo.

Estrada do Campo Limpo e Estrada de Itapecerica da Serra também são entradas e saídas. A primeira, ligando o município de Taboão da Serra ao distrito de Campo Limpo, e a segunda, o município de Embu das Artes ao Capão Redondo. Percorrer essas estradas é perceber a paisagem da periferia da cidade nas zonas mais limítrofes da capital. É observar como se constitui a grande São Paulo a partir da periferia. Bairros populosos, casas populares, becos, favelas, muita gente na rua, igrejas, muitos comércios pequenos e grandes, enormes escolas públicas, ONGs e outros serviços públicos, polícia etc. Enfim, uma circulação muito heterogênea e viva.

E, por fim, temos a estrada de M'Boi, que é a via comumente utilizada por quem mora no Jardim Ângela. Ela vai até o final do município, na divisa com Embu-Guaçu. Percorrendoa, percebe-se a precariedade das condições de vida nessa região. Seus 16 quilômetros são tomados por bairros de casas de tijolos à vista ou por favelas. A situação piora depois do terminal de ônibus do Jardim Ângela, rumo ao chamado "Fundão" do Ângela, onde se observa a precarização das condições de infraestrutura urbana, com uma presença bem maior de favelas, esgoto à céu aberto, muito lixo acumulado etc. Dizem que a situação nesse lugar fica pior por se tratar de uma região de mananciais ${ }^{4}$ da represa Guarapiranga, gerando dificuldades na implementação de melhorias de infraestrutura, de acordo com os discursos do governo.

\footnotetext{
${ }^{4}$ São áreas protegidas legalmente por serem fontes de água superficial e subterrânea utilizadas para abastecimento público.
} 
Circulo por essas ruas já há algum tempo e esses caminhos foram e seguem sendo muito significativos para mim. Ainda me surpreendem e me ensinam, pois falam sobre as desigualdades sociais na cidade, sobre a heterogeneidade da periferia, sobre a resistência e sobre as dinâmicas sociais que produzem e reproduzem estas "quebradas".

É por essa razão que inicio a dissertação com um capítulo que apresenta o território da zona sul. Nele apresento paisagens, caminhos, sujeitos, instituições e redes que percorri e que contribuíram para a construção de um olhar sobre a periferia da zona sul: diversa, desigual e resistente.

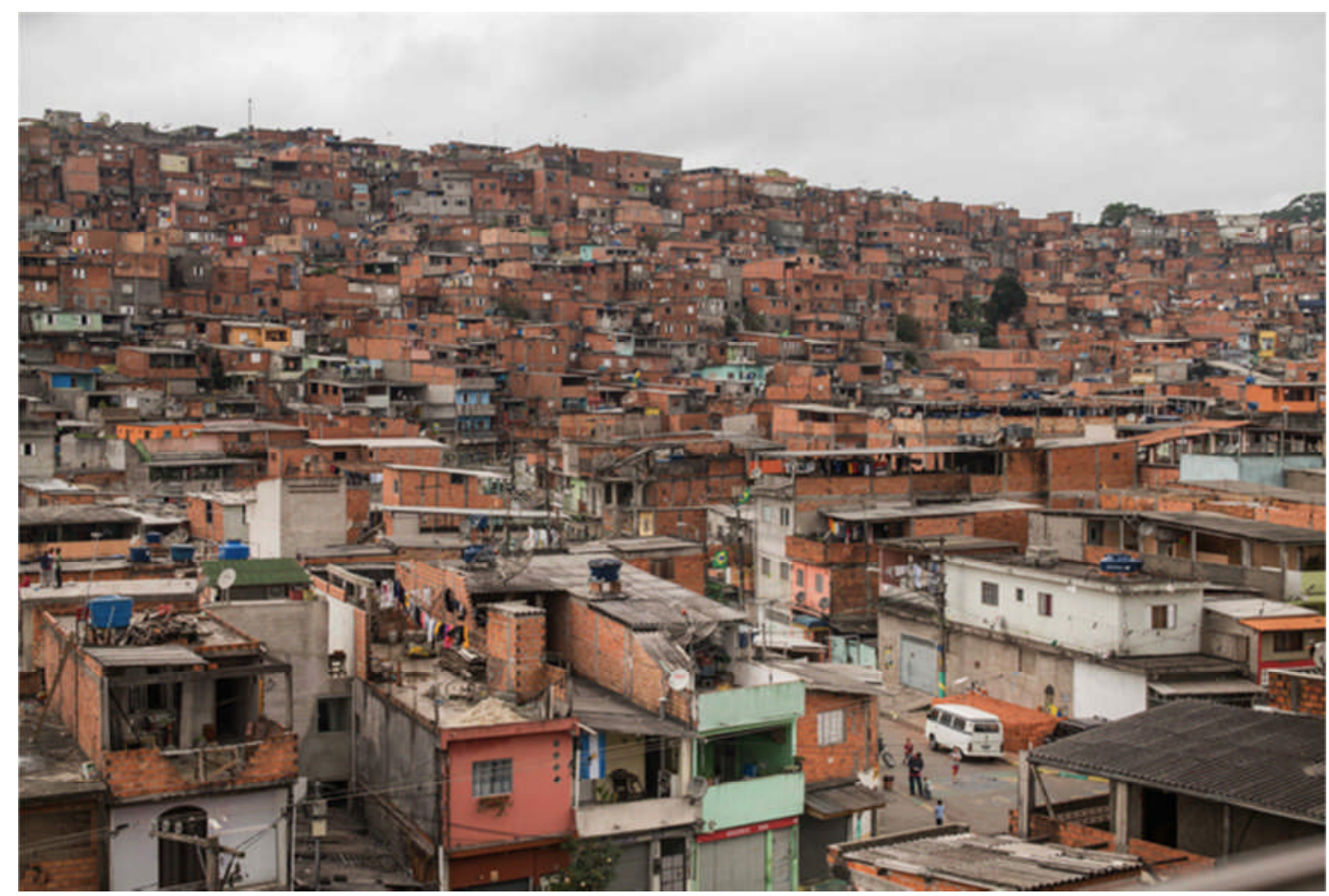

Jardim Ângela, visto da estrada do M’Boi Mirim

\section{Caminhos institucionais}

E assim como são diversos os caminhos e as paisagens, são múltiplas, também, as possibilidades de viver a sul ou pensar sobre ela. Eu cheguei por uma via institucional, trabalhando em organizações não governamentais, as ONGs. Primeiro fui contratada pela Cidade Escola Aprendiz, instituição cuja referência é o jornalista Gilberto Dimenstein, seu fundador e também colunista do jornal Folha de S.Paulo. O Aprendiz, como é chamado, apesar de estar localizado em Pinheiros, bairro nobre da zona oeste, e de focalizar suas ações nas regiões mais centrais da cidade e no âmbito das políticas educacionais, desenvolvia, 
também, algumas atividades nas periferias. $\mathrm{Na}$ ocasião, tratava-se de um projeto de articulação ${ }^{5}$ local no "Fundão" do Ângela, região dos bairros Horizonte Azul, Vila Calu e Vila do Sol, cujo objetivo era implementar uma das metodologias desenvolvidas pela instituição, a "Bairro-escola"6.

O Fundão está localizado em uma região de alta vulnerabilidade social. Os próprios moradores a distinguem do restante do Ângela chamando-a de "Fundão" ou, ainda, "da ponte pra cá”, pois ela é cortada por um riacho que desagua na represa Guarapiranga. Como mencionei anteriormente, trata-se de uma região de mananciais, em que loteamentos clandestinos e irregulares de baixa renda se mesclam com favelas. A reivindicação por melhorias no que se refere à infraestrutura e às políticas sociais muitas vezes conflita com as leis ambientais. Acompanhei diversos debates em torno da implementação de parques lineares e da desocupação das áreas de risco, bem como de problemas com reformas de escolas ou dificuldade na implementação de serviços públicos devido à quase inexistência de imóveis com documentação regular.

O projeto desenvolvia-se em torno da Honório Monteiro, escola estadual situada no bairro Horizonte Azul, com mais de 2 mil estudantes distribuídos nos ensinos fundamental I, II e médio, além de educação de jovens e adultos. Duas vezes por semana frequentava a escola, participando de encontros com professores, alunos, lideranças comunitárias e funcionários de equipamentos públicos locais. Assim, apesar de uma entrada institucional, tive contato com o cotidiano de lutas das pessoas que vivem por lá. Conheci Dona Maria dos Anjos, liderança comunitária da Vila do Sol, que militava nos finais de semana e nas horas de folga de seu trabalho de empregada doméstica no centro na cidade; José Jailson, também liderança local e agente comunitário de saúde da UBS (Unidade Básica de Saúde); Roberto Otaviano, ator e artista plástico, que desenvolvia ações culturais e atividades com jovens da região; Antonio Norberto, diretor da Emei (Escola Municipal de Educação Infantil) do Jardim Horizonte Azul, muito reconhecido pelo Aprendiz por seu "trabalho diferenciado", alinhado com os "princípios inovadores" da Educação Infantil; Deise Chaves e Luis Herculano, professores da Honório Monteiro; dentre outras pessoas que participavam desses encontros.

\footnotetext{
${ }^{5}$ Articulação é um termo muito utilizado no campo da gestão social (ONGs e políticas sociais) para se referir à mobilização de parceiros, sobretudo políticos. Na região, denota o esforço de estabelecer relações horizontais entre sujeitos, visando fortalecer uma causa ou ação.

${ }^{6}$ Bairro-escola é uma proposta de aprendizagem compartilhada que articula e aproxima escolas, comunidades, organizações sociais, empresas e poder público, visando promover condições para o desenvolvimento integral de indivíduos e territórios, com especial atenção às crianças, adolescentes e jovens." (cf. em www.cidadeescolaaprendiz.org.br/bairro-escola/)
} 
Apesar de ter ficado no projeto, assim como no Aprendiz, por apenas um ano, essa entrada na zona sul foi muito importante para entender sua heterogeneidade. Conheci uma região, o Fundão, que enfrentava graves problemas sociais: políticas sociais muito precárias; infraestrutura urbana e habitação ainda como prioridades urgentes; uma atuação violenta da polícia que, em 2011, já começava a se manifestar com mais intensidade; um território com alto controle do tráfico e de representantes do governo com ele envolvidos; lideranças comunitárias atuantes, mas frágeis e com relações muito subordinadas a representantes do governo; bem como a presença de instituições sociais tanto locais, que executavam políticas sociais em condições muito precárias, quanto ONGs com atuação na cidade, que aterrissavam ali com suas "tecnologias sociais" de forma fragmentada e distantes das demandas locais, como é o caso do Aprendiz e do Instituto Sou da Paz, que realizou algumas ações, como as Praças da $\mathrm{Paz}^{7}$, durante alguns anos na década de 2000.

A discussão proposta por Eduardo Marques que relaciona pobreza urbana, segregação e redes sociais fez muito sentido para pensar esta região. Inclusive, o Fundão do Ângela foi uma das regiões estudadas em seu trabalho. Em Redes Sociais, Segregação e Pobreza, Marques buscou ressaltar os efeitos negativos da concentração espacial da pobreza. O autor fala sobre a segregação social no espaço, isto é, a separação de grupos sociais em áreas relativamente homogêneas e distantes no território da cidade. Ele afirma que, nesse caso, as famílias têm de dar conta não apenas de sua própria pobreza, mas também do isolamento social e da privação econômica de outras famílias que vivem perto delas (Marques, 2010, p. 31). Nessas situações de segregação, as redes sociais que poderiam permitir a inserção dos indivíduos em contextos sociais mais amplos e diversos, seriam frágeis e estariam mais isoladas.

A minha impressão é a de que, embora Dona Maria e Jailson participassem de redes mais amplas - como o Fórum em Defesa da Vida, partidos políticos, sindicatos etc. -, a capacidade de atuação local era muito reduzida devido à tamanha precariedade. De fato, espaço e sociabilidade articulavam-se produzindo um maior isolamento que dificultava a superação de contradições, a articulação local, o fortalecimento de redes. E em comparação a outras articulações na região que encontraria mais tarde em distintos bairros da zona sul, no

\footnotetext{
7 O projeto Polos da Paz e Praças da Paz SulAmérica é uma iniciativa do Instituto Sou da Paz, em parceria com a empresa de seguros SulAmérica, que "promove a revitalização de praças públicas da periferia de São Paulo com a participação da comunidade e da juventude local para ocupação de praças" tendo em vista diminuir os índices de violência (cf. http://www.soudapaz.org/upload/pdf/p_los_pra_as_da_paz_sulamerica.pdf).
} 
Fundão as instituições e as redes eram realmente muito mais fragilizadas, somadas a um contexto de segregação e pobreza. Ainda incluiria um aspecto não abordado por Marques, que é a violência.

Durante o ano em que estive na região, ao menos três homicídios ocorreram e permaneceram silenciados. Um deles foi o assassinato de um jovem de 16 anos, acusado pela mãe de uma garota de seis anos de ter "mexido" com a menina. Ela recorreu ao tráfico da região, que "resolveu" o conflito. Ficamos sabendo do homicídio por professores da escola, que contavam a notícia em tom de rumor, falando em voz baixa, como se corrêssemos risco em falar sobre o assunto. Todos sabiam da morte, no entanto, a mãe do menino, que recebeu diversos telefonemas das pessoas que matavam seu filho, durante o ato, não pôde chamar a polícia. A escola, em nenhum momento, assumiu um posicionamento como órgão público frente ao fato. A própria direção temia possíveis retaliações, já que o crime organizado local oferecia a segurança necessária para a realização de eventos e em situações de conflitos.

Ali no "Fundão" do Ângela foi o lugar em que a violência do tráfico era de fato uma questão nas redes em que eu circulava. Conforme fui tendo contato com outras redes, instituições e coletivos com atuação nos bairros menos isolados, a questão passou a ser a da violência da polícia, como será apresentado mais adiante.

Saí então do Aprendiz para trabalhar no CDHEP, Centro de Direitos Humanos do Campo Limpo, que fica em uma região mais central da sul, no Capão Redondo, bem próximo ao metrô. Acreditava que atuando em uma instituição da periferia poderia desenvolver um trabalho menos fragmentado e mais conectado com a vida local, o que de fato aconteceu. Essa instituição tem uma atuação de mais de 35 anos na região. Segundo histórico publicado em seu site:

A raiz do CDHEP está no final dos anos 70 , anos da ditadura militar, quando as Comunidades Eclesiais de Base [CEBs] floresciam na Arquidiocese de São Paulo. As violações dos Direitos Humanos, sobretudo por parte da ordem estabelecida, contra os grupos de oposição que ressurgiam na sociedade civil, eram flagrantes. Como em outras partes do país, na Região Episcopal de Itapecerica da Serra também surgiu uma Comissão Pastoral dos Direitos Humanos. Com a mudança das conjunturas política e eclesial, a Comissão Pastoral virou uma ONG. Ampliou e diversificou suas atividades, sendo a questão da violência uma de suas atividades principais. ${ }^{8}$

\footnotetext{
${ }^{8}$ CDHEP - www.cdhep.org.br
} 
A história do CDHEP está vinculada ao processo vivido por muitos movimentos sociais que emergiram nas décadas de 1970 e 1980 e lutavam pelo fim da ditadura e por direitos sociais nas periferias. A proximidade com segmentos progressistas da igreja católica e com o Partido dos Trabalhadores, a posterior institucionalização, a execução de programas sociais por meio de convênios com o governo a partir da década de 1990 e o engajamento contra a violência são caminhos trilhados por várias instituições que tiveram início nesse período. Na região, dentre outras instituições, possuem trajetórias semelhantes: a Sociedade Santos Mártires, associação fundada a partir da igreja de mesmo nome em 1988, que atuava junto às CEBs da região; o Instituto Padre Josimo Tavares, fundada em 2003 a partir de lideranças que "iniciaram sua militância na década de 1980, ainda nas comunidades eclesiais de base da Igreja Católica, através da atuação nas pastorais da criança, de juventude, saúde e do dízimo"”; e a Associação Jardim Comercial e Adjacências, oriunda dos mutirões da casa própria ${ }^{10}$. Hoje, estas três instituições têm como ação principal a execução de políticas municipais de assistência social.

No entanto, não só na região, mas também em toda a periferia da cidade, se proliferaram organizações não governamentais, muitas delas motivadas justamente pelas demandas de execução de políticas sociais a partir dos anos 2000. Dessa forma, a grande maioria de ONGs na zona sul tem como principal objetivo o "atendimento", sobretudo de crianças e jovens. O CDHEP e a Santos Mártires, principalmente, são instituições que ainda desenvolvem ações de protagonismo político, como articulação e formação de lideranças locais, embora também executem serviços públicos. Ademais, vale citar a presença de algumas instituições que possuem um caráter mais comunitário, com uma organização mais "democrática" e que estão ligadas aos recentes "coletivos" de jovens que se multiplicam na periferia, como é o caso da Associação Cultural Recreativa e Esportiva Bloco do Beco, que tratarei mais à frente.

\footnotetext{
${ }^{9}$ Instituto Padre Josimo Tavares - http://ipjtavares.org.br/historia.php

10 Segundo Edson Miagusko, a bibliografia que trata da questão da autoconstrução traça sua genealogia dividindo-a em três gerações, tomando a cidade de São Paulo como cenário tendo em vista a complexa teia de agentes (movimentos de moradia com força de mobilização e enraizados em suas comunidades, assessorias técnicas criadas a partir da interação de arquitetos e outros profissionais com esses movimentos e um governo de esquerda na cidade): “O primeiro período é embrionário, com experiências pontuais da primeira geração de mutirões, na administração petista (1989-1992), visto como uma fase heróica; o segundo período corresponde às gestões Paulo Maluf (1993-1996) e Celso Pitta (1997-2000), quando os vários convênios firmados anteriormente são questionados judicialmente, as obras são interrompidas e nenhum novo convênio é assinado; e o terceiro período, dos quatro anos de gestão Marta Suplicy (2001-2004), em que os mutirões deixam de ser prioridade para o governo" (Miagusko, 2011, p. 171). Segundo este autor, tal genealogia permite problematizar a "mitologia emancipatória" que rondou não apenas os mutirões, mas também os movimentos populares da década de 1980, trazendo à tona o processo de ampliação das políticas neoliberais e de desresponsabilização do Estado, que se intensifica depois dos anos 1990. Essa discussão será retomada no próximo capítulo.
} 
Esse aglomerado de instituições, embora com atuações e históricos múltiplos, buscam intervir no "social", compondo o campo que é chamado de "gestão social" (Feltran, 2008; Calegare e Silva Junior, 2009). Minha intenção aqui não é, necessariamente, a de me aprofundar na discussão sobre este conceito, entendido também como "terceiro setor", mas sim a de utilizar um termo que seja capaz de se referir a um campo composto por instituições diversas (ligadas a diversas religiões, com origem em movimentos sociais, "braço" social de empresas etc.) que hoje estão presentes na periferia. São instituições que executam serviços públicos a partir de convênio com o governo, sobretudo municipal, e que acabam compondo uma rede local de atendimento à população. Tal rede articula-se por motivos diversos: seja em torno de algum objetivo político comum; em busca de fortalecimento mútuo; porque as instituições devem responder a um mesmo órgão público, uma vez que executam a mesma política social; ou até mesmo por conta dos sujeitos que trabalham ou são atendidos por essas instituições.

Essa discussão é abundante no campo da administração pública e, como mencionei anteriormente, não pretendo deter-me nela. No entanto, tomo de empréstimo a definição de Tânia Fischer (2002) sobre o campo da gestão social, entendendo-o como um "campo do desenvolvimento social, que se constitui como um processo social, a partir de múltiplas origens e interesses, mediados por relações de poder, de conflito e de aprendizagem" (Fischer, 2002, p.23). Foi assim que percebi o campo com minha "entrada institucional" na zona sul, formado por instituições totalmente diversas em seus princípios políticos e suas origens. Contudo, tendem a uniformizar-se a partir da execução das políticas sociais, muitas vezes a única saída para a manutenção financeira das mesmas, funcionando de modo cada vez mais burocratizado e a partir de uma lógica "tecnicista". Começava a ver nessas fronteiras entre sociedade civil e Estado as margens deste.

Neste ponto, recorro à discussão proposta por Venna Das e Deborah Poole no texto "El estado y sus márgenes" (Das; Poole, 2008). As autoras evocam o conceito de margem, propondo um distanciamento da imagem consolidada do Estado enquanto forma administrativa de organização política racionalizada, ou enquanto bloco monolítico, que tende a enfraquecer-se e desarticular-se ao longo de suas margens territoriais e sociais. Inspirandose em Mary Douglas (2012), elas buscam então entender as margens como espaços repletos de criatividade (o que não quer dizer não violentos), em que o Estado é reconfigurado pelos sujeitos envolvidos nas práticas cotidianas.

Entendo o campo da "gestão social" como uma dessas margens do Estado na periferia. Esse campo não se restringe a ações e instituições exclusivamente estatais, senão tende a 
funcionar cada vez mais a partir de uma dinâmica do Estado, entendido aqui não como uma entidade, mas sim como um modo de organização do poder que se estabelece de forma hierárquica, preocupado com estruturas e códigos, com entidades estáveis. Similar ao que Danny Hoffman (2011), fazendo referência a Deleuze e Guattari (1997), chamaria de "espaço estriado" - ou seja, claramente delineado, mapeado e fixado:

Este é o espaço da burocracia obcecado em mapear seu território através da cartografia, conduzindo censos, traçando o curso normal de casos fixados em taxação e protocolos. Estado cava trincheiras e traça linhas retas. Estado são forças reativas; eles "pensam" de acordo com paradigmas e princípios estabelecidos. O Estado limpa os caminhos que permitem ver e controlar o movimento em seu território (...) Estados realizam projetos que distinguem o legal do ilegal, o legítimo do ilegítimo, o lícito do ilícito. Estados territorializam. (Hoffman, 2011, p. 8)

Relatórios, projetos, mapeamentos, cadastros são formas já rotinizadas no funcionamento de instituições e serviços públicos dos quais me aproximei. Além do fato de que todas as pessoas que deles participam são enquadradas em alguma categoria: "atendidos", "técnicos", "gestores", "familiares", "jovens" etc. Para cada uma dessas categorias existe um protocolo. Tais práticas contribuiriam para a reprodução do racismo do Estado e para a estigmatização de jovens "atendidos" e suas famílias. Seria então possível criar nessas margens? Resistir?

Essa literatura ofereceu instrumentais para que eu pudesse interpretar o processo que vivenciei no CDHEP e em todo o campo: sobretudo, o enfraquecimento das "lutas sociais" e uma crescente burocratização das ações e do cotidiano exigida pelas instituições financiadoras, principalmente as governamentais. Mas observei também um grande esforço dos sujeitos em construir relações no cotidiano que tendiam muito mais a uma horizontalidade na produção de discursos, problematizando a imposição vertical absoluta do Estado.

Aqui, considero oportuno retomar o argumento de Veena Das e Deborah Poole que, dialogando com os conceitos de biopolítica, de Foucault, e de homo sacer, de Giorgio Agamben, afirmam que os habitantes das margens não são corpos massivos inertes submetidos ao biopoder, senão que trabalham cotidianamente com as estratégias de controle do Estado, criando maneiras de fugir de tal controle ou mesmo de reivindicar formas de cidadania.

Quando entre no CDHEP, fui lançada a um emaranhado de redes e articulações que ora "reagiam" em contra, ora "reforçavam" as práticas e os discursos estatais - redes estas muito mais fortalecidas do que aquelas com que havia tido contado no "Fundão". Primeiro, 
conheci as articulações mais institucionalizadas, ligadas a ONGs e ao poder público, como o FAS (Fórum de Assistência Social), o Fórum em Defesa da Vida, a Rede Intersetorial do Campo Limpo, as quais tratarei mais adiante. Posteriormente, fui conhecendo uma enorme quantidade de coletivos, sobretudo de jovens ligados a linguagens artísticas, que hoje também produzem um novo discurso sobre periferia e desigualdade, o qual também pretendo tratar neste trabalho. Esses coletivos são formas de organização que tendem a ser mais autônomas com relação a partidos políticos e instituições, tencionando assim estas "margens".

Assim que iniciei meu trabalho, a instituição desenvolvia basicamente duas principais frentes de atuação: o Provita (Programa Estadual de Proteção às Vítimas e Testemunhas), executado em parceria com o governo do Estado; bem como projetos e formações a partir de uma metodologia chamada Justiça Restaurativa ${ }^{11}$, com os quais estava envolvida diretamente. O Provita é um programa que tem a finalidade de proteger "vítimas e/ou testemunhas que estejam sofrendo ameaças em virtude de colaboração em inquérito policial ou processo criminal" ${ }^{\prime 2}$. Em São Paulo, este programa atua desde 1999, vinculado a diferentes secretarias - da Justiça e da Defesa da Cidadania e da Segurança Pública -, fazendo parte do Sistema Nacional de Proteção a Vítimas e Testemunhas, gerenciado pela Secretaria Especial de Direitos Humanos do Governo Federal. Sua implementação se dá por meio de convênios com instituições da sociedade civil. Em São Paulo, desde seu início, é executado pelo CDHEP. É uma ação sigilosa e efetuada distante da sede no Capão Redondo, por isso não tive nenhum contato com seu funcionamento cotidiano.

Já as ações de Justiça Restaurativa eram a principais frentes da instituição na zona sul. Foram inicialmente desenvolvidas pelas missionárias que atuavam na instituição desde 2005:

\footnotetext{
11 Justiça Restaurativa é uma metodologia criada como alternativa à punição de pequenos delitos, sobretudo juvenis. O Canadá foi o precursor, sendo a prática depois disseminada pelos Estados Unidos, pela Nova Zelândia e outras diversas partes do mundo. No final dos anos 1990, foi incorporada pela Organização das Nações Unidas que, em 2001, produziu a Declaração de Princípios Básicos de Justiça Restaurativa. Embora não haja definições rígidas acerca de seus fundamentos e práticas, costuma-se considerar "processo restaurativo": (...) qualquer procedimento em que a vítima e o ofensor, além, quando apropriado, de indivíduos outros como familiares ou membros da comunidade, participam juntos e ativamente, por meio de mecanismos de conciliação, na solução dos problemas suscitados pela prática do crime, dispondo, geralmente, da ajuda de um facilitador. $\mathrm{O}$ "resultado restaurativo", por sua vez, é o acordo alcançado ao fim de um processo restaurativo, abrangendo soluções como a reparação, a restituição e a prestação de serviços à comunidade, destinadas a responder às necessidades e às responsabilidades individuais e coletivas e centradas na reintegração social da vítima e do ofensor (Benetti, 2009, p. 44). No Brasil, a discussão sobre justiça restaurativa se dá quase que completamente no judiciário. Por essa razão, o CDHEP reivindicava uma justiça restaurativa "comunitária". As principais referências da discussão são experiências disciplinares no sistema judiciário ou educacional, sendo o Instituto Internacional de Práticas Restaurativas (http://www.iirp.edu/) uma fonte importante. Curiosamente, experiências como as Comissões de Verdade e Reconciliação da África do Sul ou outros casos paradigmáticos dos processos de reconstituição do tecido nacional e do Estado de direito pós-regimes autoritários (Moutinho, 2012) não são discutidas.

${ }^{12}$ Site secretaria de Justiça do Estado de São Paulo:

http://www.justica.sp.gov.br/portal/site/SJDC/menuitem.8f439e23c6d2bda8e345f391390f8ca0/?vgnextoid=92bd cc533f73e310VgnVCM10000093f0c80aRCRD
} 
Petronella Boonen, ligada à congregação católica missionária internacional Servas do Espírito Santo, e Joana Blaney, missionária leiga do instituto estadunidense Maryknoll Sisters of St. Domenic. As principais ações em Justiça Restaurativa desenvolvidas pela instituição eram formações junto a profissionais de vários setores do Estado (assistência social, educação e setores do judiciário), além de desenvolvimento de projetos, principalmente em parceria com o governo federal (Secretaria Especial de Direitos Humanos (SDH) e Secretaria de Políticas para as Mulheres (SPM) .

Instalado em uma ampla sede no Jardim Maria Helena, nas proximidades do metrô Capão Redondo, o CDHEP possuía poucas funcionárias quando entrei, todas mulheres na faixa etária entre 30 e 50 anos. Fui contratada para trabalhar em um projeto, fruto de convênio $^{13}$ com a SDH, obtido por meio de seleção via edital público. O projeto, chamado Tecendo Redes de Cuidado, tinha por objetivo oferecer formação em Justiça Restaurativa a profissionais de políticas sociais do distrito do Capão Redondo, sobretudo escolas, serviços de assistência social e de saúde, bem como apoiar o fortalecimento de redes, tendo em vista a diminuição de conflitos nesses serviços.

Inicialmente, uma das minhas tarefas era a de mapear as políticas sociais e mobilizar seus profissionais. Com isso levantamos, somente no distrito do Capão Redondo, mais de 150 serviços públicos, dentre os quais 28 eram equipamentos de assistência social, 91 de educação e 36 de saúde. Se considerarmos a região dos quatro distritos, esse número quadruplica. Aqui, não estou afirmando a suficiência - tanto qualitativa quanto quantitativa - das políticas sociais. Muito pelo contrário, minha proximidade com esses serviços só reafirmou a deficiência em ambas as dimensões. No entanto, a presença desses equipamentos públicos sem mencionar os de cultura, esporte, segurança, além de outros que não fazem parte da conta - merece uma atenção no que se refere a uma presença de fato do Estado na periferia. O que busquei entender neste trabalho são os efeitos dessa presença.

No território existem ações dos governos estadual e municipal. Os quatro distritos estão distribuídos na gestão do município em subprefeituras: a do Campo Limpo, que agrega Campo Limpo, Capão Redondo e Vila Andrade; e a do M’Boi Mirim, com o Jardim Ângela e o Jardim São Luís. As políticas sociais municipais são distribuídas de acordo com tal divisão.

\footnotetext{
${ }^{13}$ Convênio é acordo ou ajuste que disciplina a transferência de recursos financeiros de dotações consignadas nos Orçamentos Fiscal e da Seguridade Social da União. Participam desse acordo, de um lado, órgão ou entidade da administração pública federal, direta ou indireta, e, do outro lado, órgão ou entidade da administração pública estadual, distrital ou municipal, direta ou indireta, ou, ainda, entidades privadas sem fins lucrativos, visando à execução de programa de governo, envolvendo a realização de projeto, atividade, serviço, aquisição de bens ou evento de interesse recíproco, em regime de mútua cooperação. Cf. http://www.governoeletronico.gov.br/eixosde-atuacao/integracao/convenios
} 
As secretaria municipais e estaduais são responsáveis pela gestão das escolas das duas subprefeituras por meio das diretorias regionais de educação estadual e municipal. Já a política de assistência possui coordenadorias por subprefeitura: a do M'Boi e a do Campo Limpo, e assim por diante. Os serviços são organizados a partir dessa sobreposição de subdivisões territoriais.

A partir do trabalho de mobilização, isto é, de divulgação do projeto em que atuava no CDHEP, participei de inúmeras reuniões nos equipamentos públicos e serviços sociais. Foi assim que passei a conhecer as muitas faces desse Estado na zona sul. Visitei inúmeras escolas, tanto estaduais quanto municipais, onde tive contato com professores, a maior parte deles moradores da região e, não raro, profissionais que fazem dupla jornada de trabalho sendo contratados pelas redes municipal e estadual de educação. Tive grande contato também com a assistência social e seus profissionais. Um conjunto complexo de serviços diferenciados executados em sua grande maioria em parceria com instituições da sociedade civil. Conheci muitas assistentes sociais, educadoras, psicólogas, majoritariamente mulheres, moradoras da região. A maior parte delas contratada por instituições da sociedade civil para executar tais serviços. Dessa forma, encontravam-se em condições de trabalho mais desfavoráveis, se comparadas a funcionárias públicas dos equipamentos do Estado, que contavam com estabilidade profissional e salários maiores.

Comecei a me familiarizar com um conjunto de siglas que representavam órgãos ou serviços dessas políticas: DRE - Diretoria Regional de Educação ${ }^{14}$-, Cras - Centro de Referência de Assistência Social ${ }^{15}$-, Creas - Centro de Referência Especializado de Assistência Social ${ }^{16}$-, Saica - Serviço de Acolhimento Institucional de Crianças e Adolescentes $^{17}$-, EMEF - Escola Municipal de Ensino Fundamental -, MSE - Serviço de Medida Socioeducativa em Meio Aberto ${ }^{18}-$, CJ - Centro de Juventude ${ }^{19}$-, só para citar alguns.

As formas de execução das políticas variavam de acordo com as secretarias. Em algumas, os serviços eram executados majoritariamente pelo governo, como educação - com

\footnotetext{
14 Órgão da Secretaria Municipal de Educação, responsável pela gestão local das escolas de uma subprefeitura.

${ }^{15}$ Equipamento da Secretaria Municipal de Assistência Social, responsável pela proteção básica. É a "porta de entrada" da população para o acesso a essa política.

${ }^{16}$ Equipamento da Secretaria Municipal de Assistência Social, responsável pela proteção especial, isto é, voltado para pessoas que estejam em situação de ameaça ou violação de direitos.

${ }^{17}$ Abrigo de crianças e adolescentes, ligado à política de assistência social e executado por instituições da sociedade civil.

${ }^{18}$ Serviços ligados à política municipal de assistência social e executados por instituições da sociedade civil, voltados para adolescentes que cometeram algum tipo de infração. Está ligado à proteção especial.

${ }^{19}$ Política de assistência social, voltada para adolescentes entre 14 e 18 anos. Está ligado à proteção básica.
} 
exceção das creches, quase todas executadas por ONGs a partir de convênios com a prefeitura, e da saúde, embora as UBSs fossem todas já geridas pelas OSs (Organizações Sociais). No entanto, os serviços de assistência social eram quase todos oferecidos por ONGs, também a partir de convênios, com exceção dos Cras e dos Creas. Novamente, observa-se aqui uma ampliação e diversificação cada vez maior da "gestão social", promovida, sobretudo, pela "terceirização das políticas" que se inicia nos anos 1990 (Feltran, 2008; Miagusko, 2011).

Neste ponto, talvez seja oportuno ressaltar que as políticas de segurança, em lógica inversa, eram completamente executadas pelo poder público: polícia militar, civil e guarda municipal.

Dessa forma, em antagonismo com a ideia de uma hierarquia cujo vetor de poder único viria de instâncias superiores, por meio de procedimentos burocráticos, em direção às camadas situadas mais às franjas do Estado - ou à chamada "ponta do serviço"-, via um contexto em que as relações de poder e influência eram muito mais complexas. Assim, em conjunto com documentos e estruturas hierárquicas estatais que sustentavam a política, existiam as práticas e os discursos que as instituições executoras carregavam em sua trajetória, ainda que elas tendessem cada vez mais a se enquadrar ao modo de organização e poder do Estado.

Acerca dessa produção local de discursos e práticas, vários eram os espaços de articulação de tais serviços. O primeiro que conheci foi o Fórum em Defesa da Vida, articulação importante, que é realizada na Igreja Santos Mártires, no Jardim Ângela. Hoje, sua principal liderança é o padre Jaime, religioso irlandês que possui grande reconhecimento por sua atuação política na região desde 1987. As pessoas dizem que, para pautar alguma coisa no Fórum, é necessário convencer antes o padre Jaime, tamanha a legitimidade da sua liderança nesse espaço. Essa articulação teve início na década de 1990, com o objetivo de mobilizar a comunidade frente às altas taxas de homicídio na época, que chegaram a 116 mortes por grupo de 100 mil habitantes. Foi nesse período que começaram as Caminhadas pela Paz, que ocorrem todo 2 de novembro, dia de finados. As pautas do Fórum estão sempre ligadas a lutas por direitos, mas, sobretudo, ao binômio violência-segurança. Ele agrega lideranças da região, principalmente as mais institucionalizas, e também representantes do governo e de universidades. A participação de delegados da polícia militar e de representantes da política de segurança pública do governo do Estado incomoda muitos militantes, sobretudo aqueles ligados aos coletivos de jovens, que põem em xeque a representatividade do Fórum, deixando de participar de suas reuniões. 
No Fórum reencontrei não só Dona Maria, liderança do Fundão do Ângela, mas revi rostos conhecidos em minhas andanças na articulação do projeto Tecendo Redes: representantes da educação, algumas pessoas das medidas socioeducativas, gente da assistência social e da saúde. Tais rostos se repetiam em várias outras reuniões das quais participei: as da Rede Intersetorial do Campo $\operatorname{Limpo}^{20}$ e do Fórum de Assistência Social. Esses espaços de articulação possuíam objetivos distintos, uns visando discussão técnica de fluxos e funcionamento das políticas sociais territoriais, outros tendo em vista a especificidade da categoria. Mas todos preocupavam-se com uma atuação no interior do Estado ou em interface a ele. Buscavam influenciar ou pautar a execução de políticas. Enfim, a pauta era o Estado. Polícia comunitária como alternativa para a segurança pública; fluxos adequados de encaminhamento de pessoas atendidas pelas políticas sociais; discussões sobre determinações das secretarias - de assistência social, saúde ou educação -: tais eram as pautas dessas reuniões. Apenas recentemente o "genocídio de jovens indígenas e negros" (ou o "extermínio do povo indígena, negro e pobre", definições ainda em disputa no ativismo) entrou, não sem resistência, como tema no Fórum em Defesa da Vida, trazido por jovens integrantes de coletivos e movimentos sociais, acabando por se constituir como um dos discursos mais importantes, que tenciona o emaranhado dessas margens.

Muitos dos profissionais desses serviços começaram a participar das formações em Justiça Restaurativa oferecidas pelo projeto do CDHEP, que se tornou mais um espaço de articulação. Foi onde passei a ter contato com os relatos do cotidiano, com dificuldades, discursos e práticas dessas pessoas. Histórias que apresentavam diferentes perspectivas no que se refere ao atendimento da população, cuja esmagadora maioria era de jovens, crianças e mulheres. Educadores do MSE que entram em conflito com os Saicas devido a internações indevidas encaminhadas por estes; psicólogos entrando em conflito com policiais por "protegerem" jovens de abordagens violentas; assistentes sociais abrindo difíceis caminhos dentro do judiciário para garantir o atendimento de jovens da Fundação Casa etc.

Tais relatos indicavam a presença de múltiplos discursos e práticas que tornavam muito mais complexo o cotidiano do atendimento de jovens e suas famílias promovido por serviços públicos. E quando digo mais complexo, estou me referindo à grande quantidade de

\footnotetext{
${ }^{20}$ São reuniões mensais propostas pelo Creas. Ocorrem uma vez por mês, normalmente no CEU Campo Limpo, e participam profissionais que atuam diretamente com a população das políticas de assistência social, saúde, educação e judiciário da subprefeitura do Campo Limpo, tendo como foco fortalecer o atendimento de "casos" de forma articulada entre os serviços. Contudo, a esmagadora maioria dos participantes é dos serviços de assistência social. Há alguns gestores da saúde e poucos da educação. Nessas reuniões, são discutidas pautas diversas do interesse das políticas sociais e, também, casos atendidos.
} 
documentos normativos que orientam tais políticas (Estatuto da Criança e do Adolescente, Plano Nacional de Assistência Social, Estatuto da Juventude, Sistema Nacional de Medida Socioeducativa, dentre outros), de órgãos estatais que gerem as políticas e de instituições sociais que as executam.

Embora existisse tal multiplicidade de práticas e discursos, um aspecto que apenas posteriormente pude "desnaturalizar" foi a segmentação, ou classificação, dos sujeitos nesses campos. Havia uma divisão nítida de lugares que se estabeleciam a partir de relações de poder: os "técnicos", por um lado, e "atendidos", por outro. Os técnicos são os profissionais das políticas (assistentes sociais, educadores, psicólogos, professores). Eles possuem a técnica para lidar com questões sociais: a pedagogia, a psicologia, a assistência social, a saúde etc. E, também, detêm o poder de definir acesso a serviços, encaminhamentos de "casos", punições etc. Os atendidos, por sua vez, são famílias pobres, na maioria das vezes mães, irmãs, avós, jovens e crianças.

Os discursos e práticas voltados a essas pessoas podem oscilar entre punição, tolerância e efetivação de direitos. Dois equipamentos da mesma política de assistência social podem operar em uma lógica completamente diversa nos atendimentos. É comum inclusive tais equipamentos entrarem em conflito devido à divergências com relação a encaminhamentos possíveis de uma mesmo "atendido". Nos próximos capítulos, refletirei acerca de algumas situações como estas.

Até este momento, tentei apresentar o campo em que fui inserida a partir da minha entrada na zona sul. Campo composto sobretudo por instituições com origens, princípios e discursos variados. Contudo, quase todas elas são executoras de políticas sociais, principalmente municipais. Assim, têm incorporado práticas cada vez mais burocratizadas, segmentado de maneira crescente seu "público atendido" e estabelecido relações hierárquicas entre "população atendida" e "técnicos". Isto é, trata-se de uma organização de poder estatal que se impõe nestas margens. No entanto, estas margens estão vivas, com seus sujeitos continuamente em movimento.

Assim, além das articulações horizontais que tendiam mais a uma institucionalidade, como o Fórum em Defesa da Vida, comecei a ter contato com outros sujeitos, que tencionavam ainda mais o poder que se impunha verticalizado nestas margens. Um discurso local começava a ser produzido principalmente pelos coletivos de jovens. Uma fala que, de alguma maneira, tencionava as fronteiras entre os lugares de "técnicos" e "atendidos" a partir do reconhecimento de um "nós" periférico e racial: "nossos jovens", "nossas mães", "nossos filhos", "nossos irmãos" e não os "atendidos" ou "usuários" dos serviços sociais. 
Fui conhecendo esses discursos e coletivos a partir de meu contato com Alessandra Tavares, Coordenadora do Centro de Juventude do Instituto Padre Josimo Tavares e professora da Rede Estadual, que posteriormente foi trabalhar no CDHEP; Márcio Bhering, liderança da Vila das Belezas, que trabalhava na ONG Sou da Paz e depois começou também a trabalhar no CDHEP; Sulamita Assunção, técnica do MSE Capão II, equipamento municipal; Elaine Lima, técnica do SME Capão II; dentre outras pessoas. Esses sujeitos e suas vozes estão presentes ao longo dos próximos capítulos.

Tive contato com essas pessoas por vias institucionais e foi a partir delas que conheci uma grande rede composta por coletivos e ativistas locais por meio da qual novos discursos sobre a periferia eram produzidos, pautados na identificação racial e na questão de gênero e sexualidade, além de denunciar a violência e o racismo do Estado. Esses novos discursos começariam então a tencionar o campo da "gestão do social", sobretudo no que se refere à execução das políticas sociais.

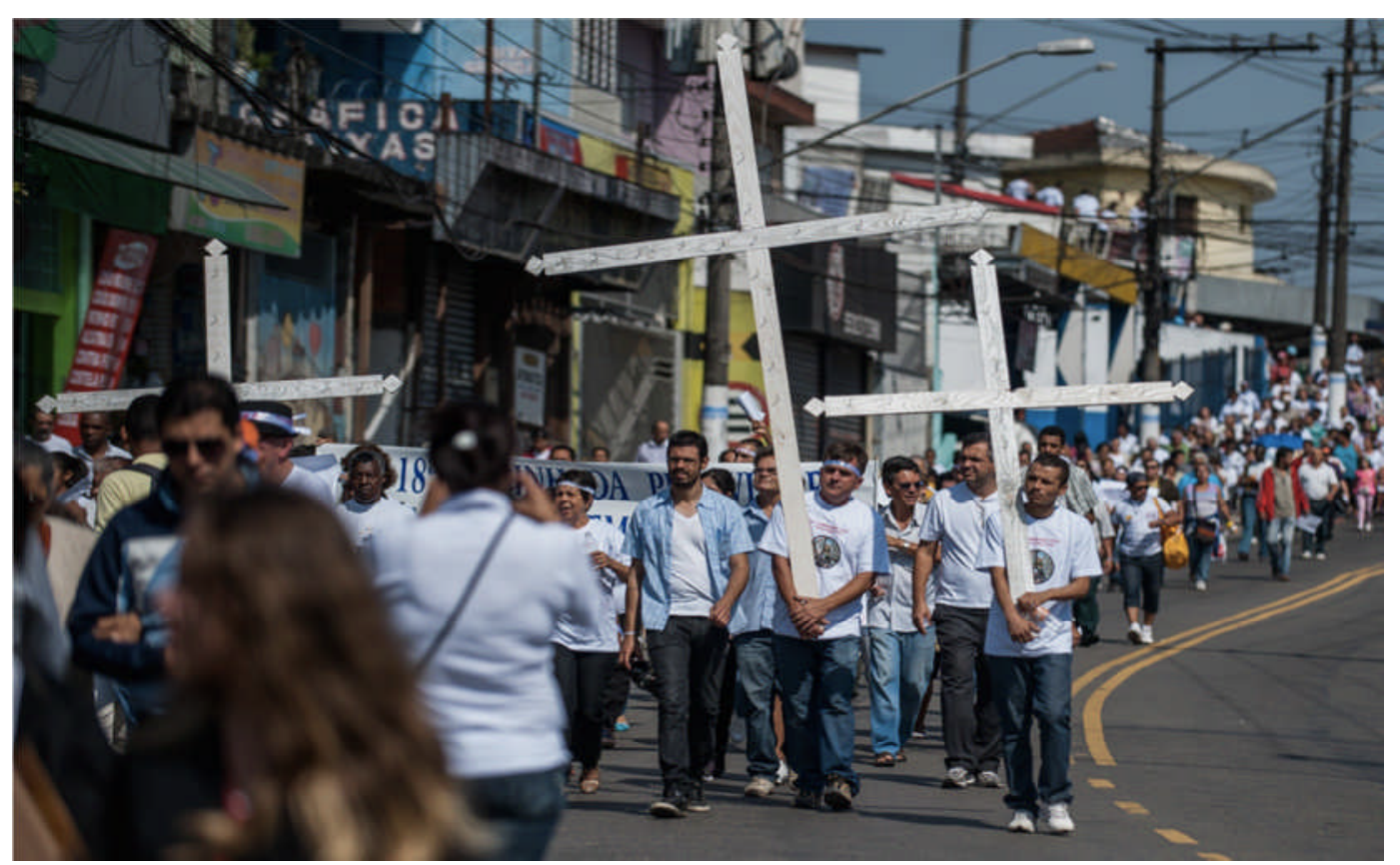

Caminhada pela Vida e pela Paz, organizada pelo Fórum em Defesa da Vida, que acontece todos os anos. Na foto, trata-se da caminhada de 2013, cujo tema foi "Por que o senhor atirou em mim?", em solidariedade à Vila Medeiros, zona norte, devido à morte de Douglas Rodrigues, alvejado por um policial. 


\section{Coletivos, sujeitos e resistências}

Juventude suicida,

Juventude suicida,

Poesia salva a vida

A vida de um moleque

Que mora na favela

Eu vou dizer para você

Pode crer que não é bela

A vida é constante, mas nós segue adiante

na luta pela vida

e pelo amor,

na luta pela paz

que é o que sempre faltou

O governo finge que não vê, porque lucra com isso

Agora quero saber, com quantos pobres se faz um rico?

- Juventude Suicida, Duck Pedro

Esta poesia foi "disparada" por Duck, William e Douglas, integrantes do coletivo Tamo Vivo ${ }^{21}$, durante evento solene para o lançamento do Plano Juventude Viva ${ }^{22}$, que seria implementado na região pela Secretaria Municipal de Direitos Humanos, realizado em outubro de 2013 no teatro do $\mathrm{CEU}^{23}$ Casa Blanca, no Campo Limpo. Na audiência, havia uma plateia composta por ativistas locais, adolescentes "atendidos" e profissionais dos serviços públicos locais. Os três jovens, para surpresa de todas e todos ali presentes, tomaram de assalto o microfone invadindo o palco, causando aparente constrangimento nas autoridades

\footnotetext{
${ }^{21}$ Duck, William e Douglas são três jovens da região que, desde 2012, compõem o coletivo Tamo Vivo, que realiza o sarau "Preto no Branco", no Jardim Ibirapuera, distrito do Jardim São Luis.

${ }^{22}$ Plano criado pelo governo federal a partir da Coordenadoria de Juventude e da Secretaria de Políticas de Promoção da Igualdade Racial, tendo por fim desenvolver ações de "prevenção" de homicídios de jovens negros e pobres. O Plano é muito questionado por ativistas na região sul, como será tratado no capítulo 5 desta dissertação.

${ }^{23}$ Centro Unificado de Educação. Equipamento público municipal que integra ações de educação, cultura e esporte. Há 46 CEUs espalhados pela periferia da cidade.
} 
que compunham a mesa: o então coordenador de juventude, Gabriel Medina; o secretário de direitos humanos Sérgio Sotilli; o vereador Netinho de Paula; dentre outros. A plateia vibrava com a audácia e a provocação dos três, pois muitas lideranças locais, majoritariamente ligadas a coletivos da região, viam a implementação do Plano com muita desconfiança. Entendiam-no como "mais uma ação do governo voltada para interesses próprios em vez das reais demandas dos jovens da quebrada", como muitas ativistas afirmavam. Depois do terceiro poema, o coordenador de juventude, visivelmente irritado, retirou o microfone dos jovens, voltando à programação prevista.

Desde 2012 lideranças da região e a coordenadoria de juventude iniciaram, não sem conflitos, um processo para a implementação de um projeto piloto do Plano na região. $\mathrm{O}$ Juventude Viva é uma iniciativa do governo federal, coordenada pela Secretaria Nacional de Juventude $(\mathrm{SNJ})^{24}$ e pela Secretaria de Políticas de Promoção da Igualdade Racial (Seppir) ${ }^{25}$. Conforme o Guia de implementação para Estado e Municípios (2004), o Plano propõe reunir ações que (...) reduzam a vulnerabilidade de jovens negros prevenindo situações de violência física e simbólica, a partir da criação de oportunidades de inclusão social e autonomia para os jovens entre 15 e 29 anos.

As ações do Plano visam a ampliação dos direitos da juventude, a desconstrução da cultura de violência, a transformação de territórios atingidos por altos índices de homicídios e o enfrentamento ao racismo institucional, com sensibilização de agentes públicos para o problema $^{26}$.

\footnotetext{
${ }^{24}$ Vinculada à Secretaria-Geral da Presidência da República, a Secretaria Nacional de Juventude (SNJ) tem a tarefa de coordenar, integrar e articular as políticas de juventude, além de promover programas de cooperação com organismos nacionais e internacionais, públicos e privados, voltados para o segmento juvenil.

${ }^{25}$ Antes do Impeachmant que destituiu a presidenta Dilma Rousseff da presidência da república, a Seppir era vinculada ao Ministério das Mulheres, Igualdade Racial e Direitos Humanos, com o objetivo de promover a igualdade e a proteção de grupos raciais e étnicos afetados por discriminação e demais formas de intolerância, com ênfase na população negra. Com a extinção deste ministério, permanece na condição de Secretaria Especial de Políticas de Promoção da Igualdade Racial, passando a ser vinculada ao Ministério da Justiça e Cidadania.

${ }^{26} \mathrm{http}: / /$ juventude.gov.br/juventudeviva/o-plano\#.Vcl-YOWYQfo
} 


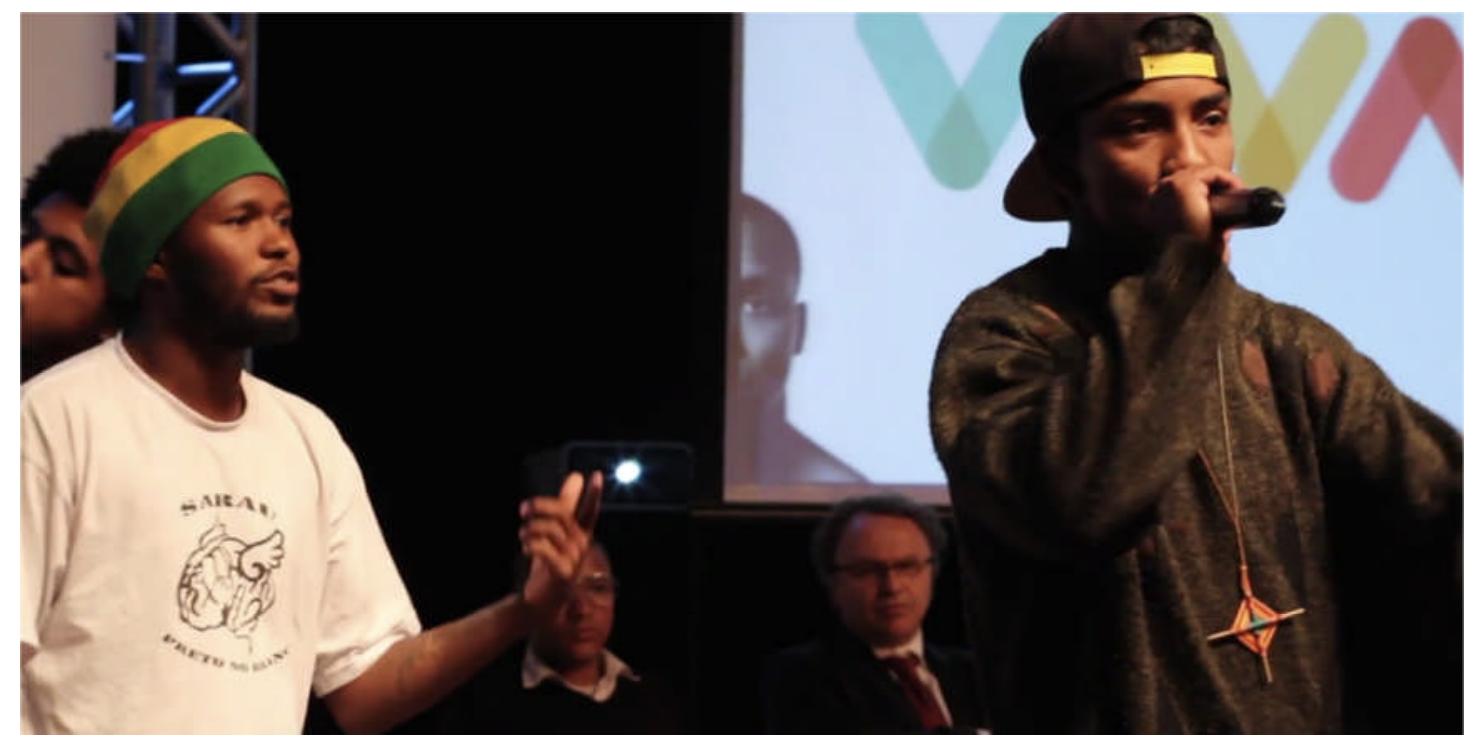

Evento de Lançamento do Plano Juventude Viva

Sua implementação se dá via adesão dos municípios, que são responsáveis também pela gestão. No caso de São Paulo, o Plano é executado pela Secretaria Municipal de Direitos Humanos por meio da coordenadoria de juventude. Ele é destinado a territórios com altos índices de violência. No caso de São Paulo, a partir de dados do Sistema de Informações sobre Mortalidade do Ministério da Saúde (SIM) ${ }^{27}$, Campo Limpo, Capão Redondo, Jardim Ângela e Jardim São Luis estão entre os distritos que apresentam maiores índices ${ }^{28}$. Por esta razão, as subprefeituras de M'Boi Mirim e do Campo Limpo foram selecionadas para a implementação do projeto piloto.

Para a realização do Plano no território, foi criado na região um comitê gestor local, formado por representantes da sociedade civil e do governo (estes, no caso, podem ser divididos em duas categorias: os representantes da coordenadoria de juventude, gestores do Plano ligados à secretaria e distantes da região; e os profissionais das políticas sociais locais de diversas secretarias). Tal instância tinha por fim acompanhar a implementação do Plano.

Formou-se então o comitê regional para a implementação do Plano, do qual participavam na ocasião diversas instituições e coletivos locais (CDHEP, ABanca, Capulanas, Coletivo Katu, Jovens Urbanos, União Popular de Mulheres, dentre outros) e representantes

\footnotetext{
${ }^{27}$ O Sistema de Informação Sobre Mortalidade (SIM), desenvolvido pelo Ministério da Saúde em 1975 e informatizado em 1979, tem como finalidade reunir dados quantitativos e qualitativos sobre óbitos ocorridos no Brasil.

${ }^{28}$ Informações extraídas de matéria realizada pela ONG Ação Educativa sobre a implementação do Plano no Município de São Paulo. http://www.acaoeducativa.org.br/index.php/juventude/37-juventude-eparticipacao/10004836-plano-juventude-viva-chega-ao-municipio-de-sao-paulo-programa-sera-implementadoinicialmente-nos-distritos-de-campo-limpo-e-mboi-mirim
} 
dos serviços públicos da região: educação (pessoas mais ligadas à diretoria de ensino do que pessoas que trabalham diretamente nas escolas, como professores, coordenadores pedagógicos ou diretores), saúde (também pessoas ligadas à gestão regional) e assistência social (estes sim com profissionais dos equipamentos: assistentes sociais, educadores, psicólogos e também gestores locais). Este conselho, apesar não ter um papel definido com clareza, como afirmam os participantes, tinha a função de planejar as ações juntamente com o governo.

Várias reuniões foram realizadas ao longo de mais de dois anos, algumas das quais tive a oportunidade de participar. Logo nos primeiros encontros estabeleceu-se certa tensão entre representantes da sociedade civil e representantes da secretaria de juventude. Para os participantes, havia não só pouca transparência e planejamento nas ações do Plano por parte do governo, mas também pouco apoio às atividades desenvolvidas pela sociedade civil.

Além de dificuldade de entendimento entre representantes do governo e representantes da sociedade civil, desde 2013, ano de implementação do Plano, ocorreram diversas chacinas na região, intensificando ainda mais os conflitos internos ao comitê. Márcio Bhering e Vitor Silva, ativistas e representantes da sociedade civil, produziram um texto sobre o processo de implementação, em que descrevem essas tensões:

2015 já começa com uma notícia triste na região. No início de março acontece a chacina na avenida Fim de Semana, na qual 12 pessoas são mortas numa madrugada. Motoqueiros encapuzados passam atirando nos bares. Um misto de revolta e medo ronda toda comunidade, mas o que mais revolta é a postura da Prefeitura Municipal de São Paulo em relação ao fato. O prefeito não se manifesta, a SMDHC (Secretaria Municipal de Direitos Humanos e Cidadania) não consegue se articular com a comunidade e organizações locais para pensar em ações efetivas e tudo se resume a uma foto do subsecretário com uma moradora que perdeu um filho. Para tornar a violação de direitos ainda mais dramática, no Cemitério São Luiz, onde foram enterrados todos os mortos, as famílias tinham apenas 15 minutos para velar seus mortos. (Bhering; Silva, 2016, p. 40).

O contexto de implementação do Plano e os conflitos que eclodiram durante o processo serão tratados no capítulo 5. Por enquanto, o que pretendo destacar são os distintos posicionamentos que se evidenciavam entre os participantes desse comitê. Um deles era o da equipe da coordenadoria de juventude, que parecia ter pressa com a implementação do Plano, tentando lidar com a burocracia estatal e com os dilemas políticos internos ao governo, pouco transparentes para nós. Davam a impressão de que as reivindicações de lideranças locais, não cabendo entre as prioridades da coordenadoria, ficavam para segundo Plano. Aos poucos, os 
integrantes do comitê foram percebendo que já existia um conjunto de ações previsto para o território planejado em outras instâncias do governo, tais quais: iluminação de alguns locais considerados perigosos, abertura de editais voltados a instituições e coletivos locais para atuação com juventude, diagnóstico local, realização de campanhas contra o racismo, articulação das políticas sociais locais etc. São ações constantemente colocadas em xeque por representantes da sociedade civil, sobretudo por não terem sido planejadas juntamente com o comitê gestor.

Os integrantes que representavam a sociedade civil, por sua vez, possuíam um discurso bem mais "crítico" ao governo. Traziam a urgência dos homicídios e cobravam o tempo todo um posicionamento mais efetivo do município no que se refere à ação da polícia militar e ao enfrentamento junto ao governo do Estado. Quando faziam menção aos jovens mortos, falavam em "nossos jovens", "nós estamos morrendo", diferenciando-se do discurso de representantes do governo, que se referiam a um "público-alvo", a um "eles", ao aludir às vítimas e suas famílias. O discurso dos representantes da sociedade civil correspondia a uma fala dos jovens da periferia falando sobre si e sobre a periferia.

Por fim, compunham também o comitê os representantes das políticas sociais da região: gestores locais das políticas e profissionais dos serviços. Uma parte destes, principalmente os profissionais dos serviços, não se sentia representante nem do governo, nem tão somente da sociedade civil, pois a maioria eram funcionários contratados por ONGs que executam as políticas sociais. Alguns deles eram também ativistas locais. No entanto, naquele lugar, assumiam uma posição mais próxima ao governo por ser "arriscado" se expor demais, como afirmavam os que mais se alinhavam ao discurso dos representantes da sociedade civil. Normalmente, quando o conflito acirrava entre secretaria e lideranças, eles silenciavam ou oscilavam em favor do governo.

Esse discurso do "nós" me chamava a atenção e estabelecia uma diferença significativa com o "eles" a partir do qual a maioria dos "técnicos" das políticas sociais, sobretudo os representantes da coordenadoria de juventude, se referia aos jovens. As ações dessas políticas, e também do Plano, mesmo que ancoradas nos princípios mais progressistas de direitos humanos, voltavam-se para um "público-alvo", para um "eles" pobre, negro e vulnerável - uma vulnerabilidade que estabelecia uma fronteira muito tênue com a periculosidade, como desenvolverei nos capítulos 4 e 5 .

Neste momento, o importante a ressaltar é que a partir deste processo de articulação do Juventude Viva passei a ter maior contato com discursos sobre um "nós" periférico 
produzido por outros coletivos da região, que se multiplicavam nestes anos em que passei a viver a zona sul. Do próprio Comitê Juventude Viva se desprendeu o Comitê Juventude e Resistência, formado por lideranças que, desde então, vêm promovendo atividades relacionadas ao "genocídio da população preta e pobre".

Tamo Vivo ${ }^{29}$, Fala Guerreira ${ }^{30}$, Periferia Segue Sangrando ${ }^{31}$, Núcleo Mulheres Negras $^{32}$ são outros coletivos que conheci posteriormente. E este tipo de organização vem se multiplicando, principalmente entre os jovens. São grupos que se articulam em torno de uma "luta" ou linguagem artística e organizam atividades diversas.

Esses coletivos não são institucionalizados, embora alguns possuam CNPJ (Cadastro Nacional de Pessoa Jurídica). Entre os que eu conheço, não são constituídos a partir de estruturas hierárquicas, inclusive refutam tal possibilidade. Também não há uma tendência de expansão ou fusão de coletivos. Pelo contrário, atuam de forma autônoma. No entanto, eles se conhecem e se apoiam. Seus integrantes participam espontaneamente das atividades uns dos outros. Normalmente, uma mesma pessoa faz parte de mais de um coletivo. Racismo, feminismo, violência do Estado, periferia, sexualidade são pautas que atravessam diversos coletivos, produzindo discursos que se influenciam mutuamente. Mesmo os coletivos artísticos, como os de saraus, teatro, dança, produzem uma arte "engajada", que expressa esses temas em suas produções.

São também diferentes no grau de organização e capacidade de mobilização. O Tamo Vivo, por exemplo, é um coletivo formado por jovens poetas de até 25 anos, responsável pelo Sarau Preto no Branco. Depois do fortalecimento da pauta feminista na região, começou, inclusive, a realizar também o Sarau Preta na Branca, "em que as minas assumem" as atividades. Já foram subsidiados pelo VAI (Programa de Valorização de Iniciativas Culturais) ${ }^{33}$. Já o Comitê Juventude e Resistência é um coletivo que tem como pauta principal “o genocídio da população negra, pobre e periférica", nascendo do desligamento de alguns participantes do Comitê Juventude Viva, como exposto anteriormente. Desenvolve diversas

\footnotetext{
${ }^{29}$ Coletivo de jovens que teve início a partir da organização do Sarau Preto no Branco, no Jardim Ibirapuera. Cf. https://www.facebook.com/coletivotamovivo/?fref=ts

30 Coletiva Feminista formado por jovens mulheres da zona sul. Cf. https://www.facebook.com/falaguerreira/info/?entry_point=page_nav_about_item\&tab=page_info

${ }^{31}$ Coletivo organizado por mulheres na zona sul, tendo em vista propor ações que ressignifiquem o dia da mulher.

${ }^{32}$ Núcleo formado por mulheres negras que, a partir de partilha de histórias sobre si, buscam o enpoderamento, a construção de sororidade e a cura.

${ }^{33}$ Ação do governo municipal que subsidia projetos culturais de jovens ou voltados para a juventude de baixa renda. Possui duas categorias: VAI I, voltado para jovens de até 29 anos; e VAI II, cujo proponente não precisa ser jovem, embora as ações devam ser voltadas para juventude. O acesso ao subsídio é via concurso público, a que os interessados devem submeter suas proposta. Diversos coletivos da região sul já foram contemplados por esta política, que é reconhecida por fortalecer grupos e coletivos culturais na periferia.
} 
ações junto a equipamentos públicos da região. O Fala Guerreira é um coletivo feminista, que também contou com subsídio do VAI e busca dar visibilidade e voz para as mulheres da periferia, fortalecendo ainda um feminismo periférico.

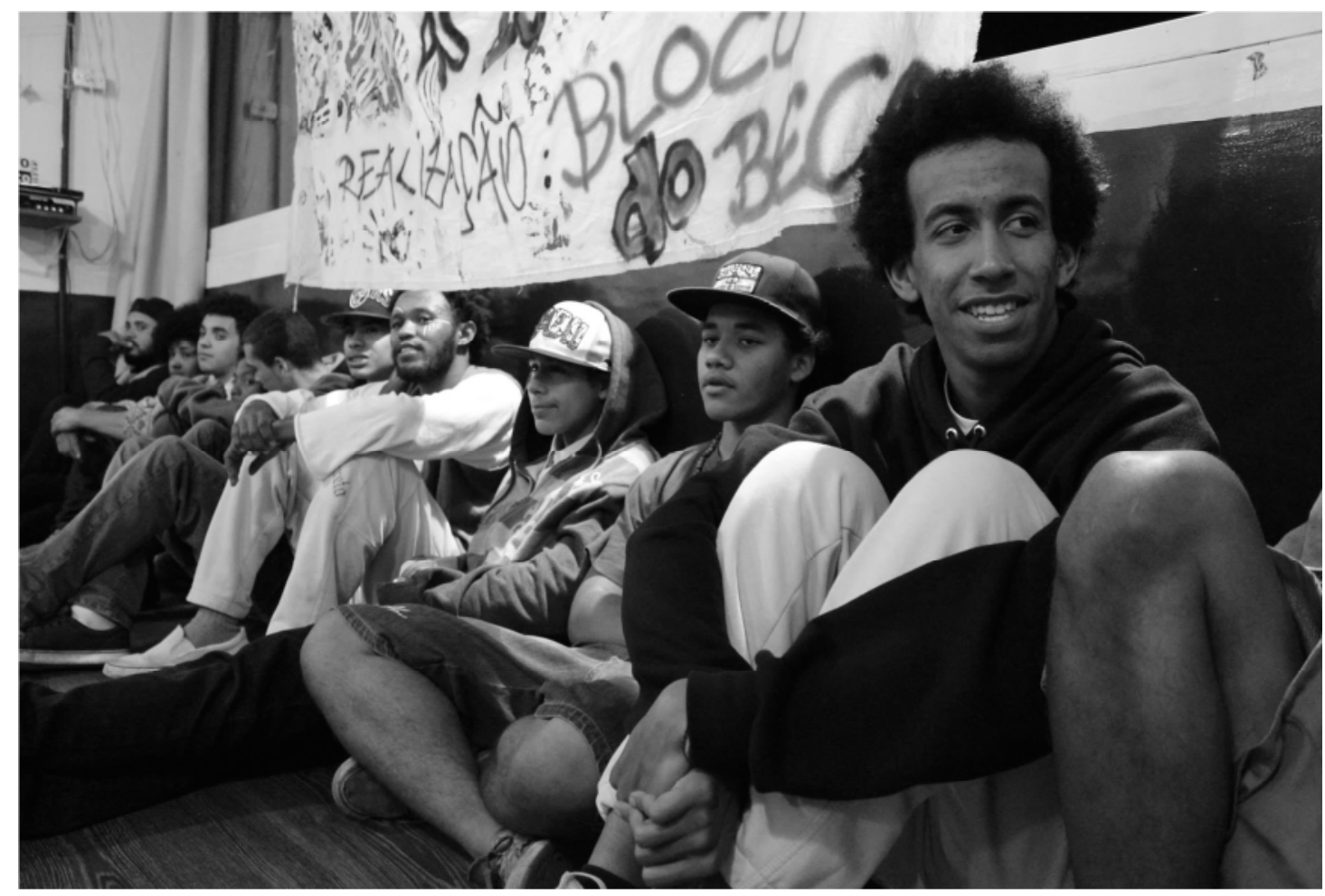

Sarau Preto no Branco, realizado pelo coletivo Tamo Vivo

Embora sejam autônomos, esses coletivos estão cotidianamente fortalecendo discursos de uma forma que entendo como sendo mais "horizontal", se comparados a princípios e políticas que se impõem de forma mais vertical a partir de instituições, suas normativas e protocolos. Além disso, esses coletivos estão a todo momento tencionando as margens do Estado - seja porque seus participantes são constantemente convidados a desenvolver ações em equipamentos e serviços públicos da região; seja a partir de ações de enfrentamento ao Estado, como o apoio de muitos coletivos às "ocupações" de escolas e equipamentos de cultura que tiveram início no final de $2015^{34}$; ou mesmo por seus integrantes trabalharem em algum serviço ou equipamento público.

Tais coletivos, certamente não os únicos da zona sul, são lugares de "empoderamento" de jovens, sobretudo mulheres que constroem discursos de denúncia das

\footnotetext{
${ }^{34}$ As escolas estaduais foram ocupadas por estudantes em protesto contra a reestruturação da rede de ensino iniciada pelo governo de Geraldo Alckmin, que previa o fechamento de escolas e a diminuição de salas de aula. Na região sul, mais de 20 escolas foram fechadas. Em maio de 2016, a Fábrica de Cultura do Capão Redondo, equipamento da Secretaria Estadual de Cultura gerido pela ONG Poiesis, também foi ocupada por jovens devido à redução de atividades e à demissão de educadores.
} 
violências sociais, principalmente acerca dos efeitos - na constituição de si e na vida cotidiana - provocados pelo racismo, pelo machismo e pela desigualdade social.

Periferia segue sangrando e não estanca. Não estanca porque nós mulheres sangramos diariamente espalhadas pelas periferias das cidades. Sangramos em carne viva, sangramos o sangue fértil da nossa menstruação, sangramos os dessabores e o peso do mundo em nossas costas. Mas, se sempre sangramos solitária e silenciosamente, descobrimos que é na nossa união que mora a potência. E veja, não é difícil sangrar quando olhamos para nossas vidas e as das demais mulheres em nossos caminhos, percebendo que quase sempre estamos relegadas a ocupar um sublugar, vistas pelo prisma de uma subinteligência, que nos olham como donas de subvontades, subprazeres, subcriações e, por fim, como seres que nasceram para exercer uma subexistência. (Teixeira e Nascimento, 2016, p. 85)

Este trecho do texto - produzido por Carolina Teixeira e Jenyffer Nascimento, ambas d coletivo Periferia Segue Sangrando - expressa o aspecto de denúncia da violência social e de potencia a partir do reconhecimento de si e do outro. Aqui, então, não me restrinjo apenas a retomar a discussão proposta por Veena Das e Deborah Poole sobre o trabalho cotidiano dos habitantes das margens, que não estão simplesmente submetidos ao biopoder, mas sim em constante movimento, buscando formas de resistência. Quando essas mulheres falam sobre o "peso do mundo em nossas costas", elas estão falando sobre uma violência social que gera sofrimento para as mulheres, principalmente para as que se identificam como negras da periferia. Ou seja, estão operando com uma gramática articulada com os marcadores sociais da diferença (raça, gênero e classe), tendo em vista não só a reivindicação do reconhecimento da vítima, mas também o reconhecimento do machismo como uma violência. Aqui, sinalizo uma discussão que retomarei no capítulo 5, já tratada por outros autores, que é a gramática do sofrimento a fim de se reivindicar direitos (Moutinho, 2012; Sarti, 2011).

É justamente a partir dessa gramática que também se propõem uma saída, por meio do reconhecimento do sofrimento que é partilhado pelas mulheres e pela possibilidade de união: “é na nossa união que mora a potencia”. 


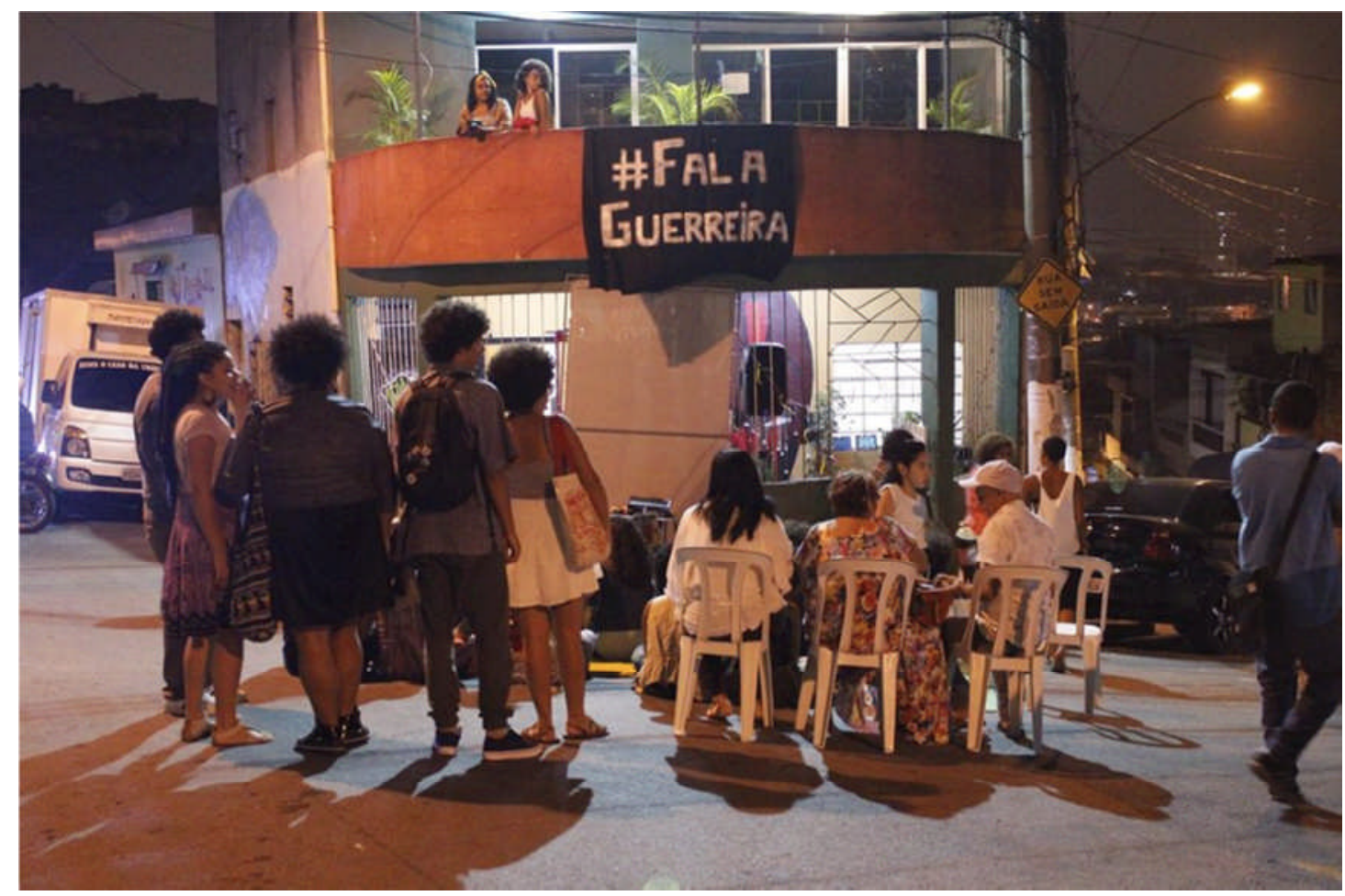

Evento do Coletivo Fala Guerreira, no Jardim Ibirapuera, distrito do Jardim São Luis.

Entendo que o sofrimento social gerado por violências sociais (Kleinman, 2009) sobretudo o racismo e o machismo, bem como as violências de Estado que os reproduzem são as chaves a partir das quais esses coletivos articulam suas "lutas"e constroem identidades, como retomarei nos capítulos 4 e 5 deste trabalho. Aqui, trata-se de denunciar racismo e machismo em uma perspectiva que não é apenas das relações interpessoais - ou dito em outras palavras, na perspectiva da interação (Moutinho, 2004) - , apontando como tais violências também são reproduzidas institucionalmente

Considero a discussão proposta por Judith Butler sobre vidas precárias como fundamental para entender a disputa discursiva que começa a se forjar nestas margens do Estado. Segundo a autora, algumas vidas não são qualificadas enquanto tais Existem normas e condições historicamente articuladas e reforçadas que garantem o reconhecimento de uma vida e, assim, de sua precariedade. Por precariedade Butler entende a necessidade que uma vida tem de que algumas condições econômicas e sociais sejam atendidas para serem mantidas enquanto vida, demandando, assim, proteção e garantias sociais. É reconhecer que uma vida importa e, por conseguinte, seja passível de luto.

Argumenta Butler que o enquadramento fornecido pela norma permite o reconhecimento de que uma vida é vida e, assim, de que sua condição é precária. No entanto, tal enquadramento deixa fora do reconhecimento outras vidas que não correspondem a esta 
norma, vidas que não são reconhecidas como precárias, que não importam e, assim, não são passíveis de luto.

Essa distribuição diferencial da condição de precariedade é, a um só tempo, uma questão material e perceptual, visto que aqueles cujas vidas não são consideradas potencialmente lamentáveis e, por conseguinte, valiosas, são obrigados a suportar a carga da fome, do subemprego, da privação de direitos legais e da exposição diferenciada à violência e à morte. (Butler, 2015, p. 45-46)

O estigma do "perigoso", do "bandido", a ideia de que "bandido bom é bandido morto", a invisibilidade da violência vivida por mulheres, sobretudo negras, da periferia, expressam exatamente essa ideia de vida não é passível de luto. Na prática, vê-se pouca ou nenhuma comoção frente às altas taxas de jovens negros mortos na periferia, ou mesmo às violências vividas pelas mulheres, à insuficiência de políticas sociais, aos efeitos da desigualdade etc. Vulnerabilidade é termo corrente nas ações do Estado na periferia, mas seria este termo realmente correspondente ao reconhecimento da vida precária de seus moradores? Essa questão tentei desenvolver no capítulo 5.

Mas, continuando o argumento de Butler, é possível "enquadrar o enquadramento", isto é, "questionar a moldura mostrando que ela nunca conteve de fato a cena a que se propunha ilustrar"? Ela nos oferece uma forma de interpretar esses discursos que emergem reivindicando o reconhecimento do sofrimento de jovens e mulheres negras e pobres e suas famílias frente à violência social, sobretudo do Estado. Tais discursos rompem os limites a partir dos quais o enquadramento se constitui. Assim, quando estes ativistas falam em “genocídio de jovens negros e pobres", eles estão propondo um enquadramento que rompe com a ideia de bandido, substituindo-a por jovem, além de explicitar as normas a partir das quais o enquadramento do "bandido" é constituído, que é o racismo do Estado (Foucault, 1976).

Os discursos produzidos por esses coletivos e seus ativistas estão construindo e oferecendo novas "matrizes interpretativas", capazes de confrontar interpretações dominantes que não somente atuem sobre a comoção, mas também possam ganhar forma própria de comoção, tornando-se assim efetivas. (Butler, 2015; p. 84). Trata-se, pois, de tentar redefinir uma economia moral em que o sofrimento gerado por violência sociais que normalmente recaem sobre os "perigosos" ou "invisíveis" seja reconhecido.

Tais discursos e matrizes não só tencionam as práticas e os discursos do Estado. Eles também desestabilizam aqueles que talvez possamos chamar de "antigos", que emergiram nos movimentos sociais dos anos 1980 e exerceram influência sobre a ação de muitos ativistas 
que hoje estão à frente de instituições e articulações mais consolidadas na periferia, incluindo aqueles mais próximos ao governo, como os que executam as políticas sociais. Para estes, a "luta" seria por direitos e pela abertura de espaços democráticos no interior do Estado, visando a construção e gestão das políticas sociais, em que assumiriam papel fundamental os conselhos, fóruns, e outras instâncias intersetorias como Conjuve (Conselho Nacional da Juventude), CMDCA (Conselho Municipal dos Direitos da Criança e do Adolescente), Fórum Nacional de Direitos Humanos etc.

Para esses novos coletivos e ativistas, embora não se tenha um posicionamento consolidado, a questão não seria a de almejar uma "parceria" com o Estado, mas sim a de denunciar as múltiplas formas de violência protagonizadas por ele. Do Estado, deve-se proteger. É por esta razão que foi tão difícil pautar no Fórum em Defesa da Vida o "genocídio da juventude negra e periférica" - ou mesmo a "desmilitarização" da polícia, uma vez que o Fórum, desde a década de 1990, reivindicava a implementação de uma polícia (militar) comunitária.

Esses novos discursos começam a penetrar no campo da "gestão social" em que se executam as políticas sociais, influenciando práticas e discursos de profissionais, tencionando ainda mais a relação entre setores do Estado e entre os próprios equipamentos públicos, ou mesmo problematizando o sentido da existência de algumas políticas sociais.

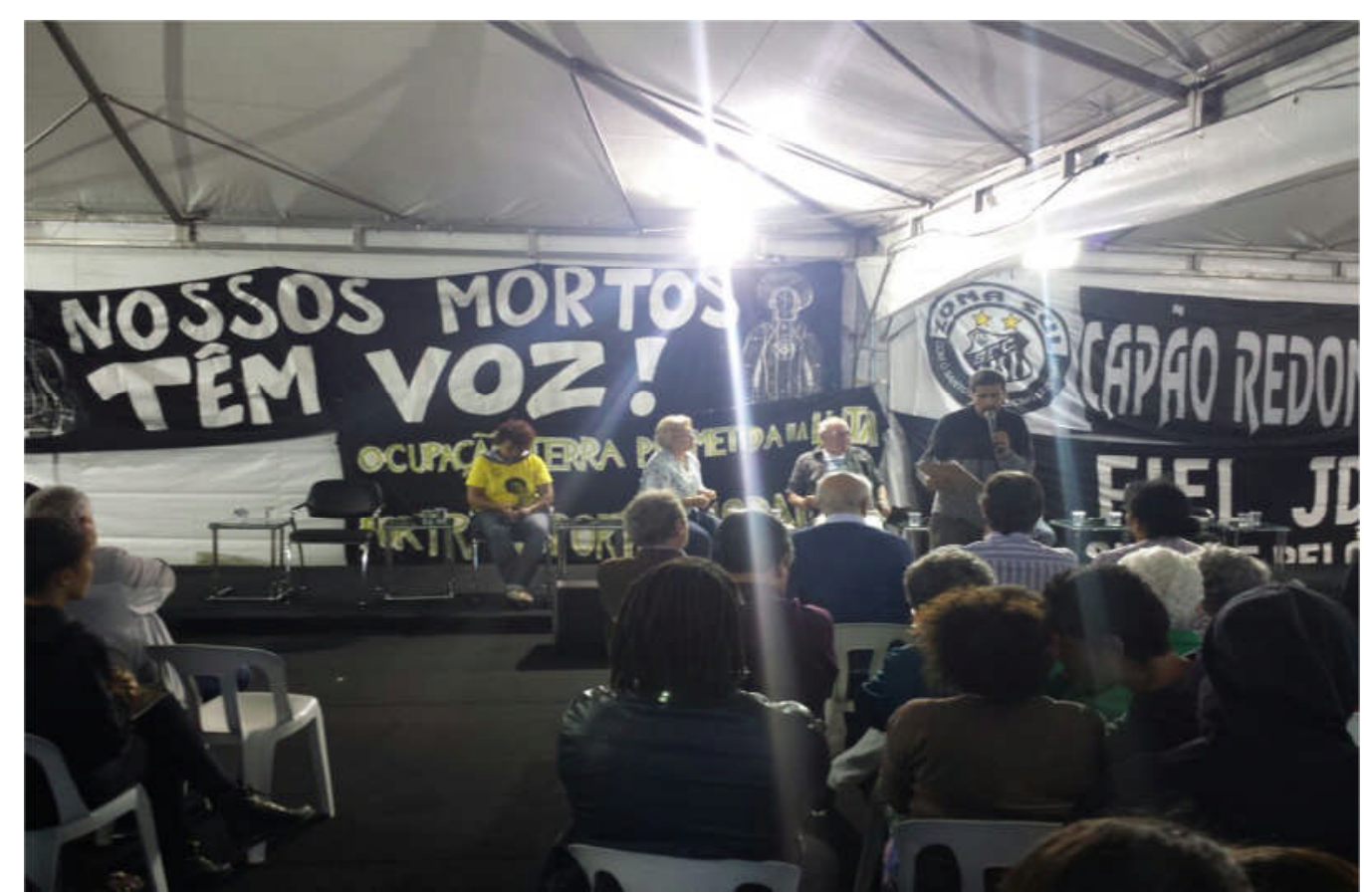

Audiência pública sobre homicídios de jovens na região, promovida pelo Coletivo Juventude e Resistência, Movimento Mães de Maio e Coordenadoria Municipal de Juventude. 
Neste capítulo, busquei apresentar meu campo e a maneira com que nele entrei: instituições, políticas sociais, sujeitos e articulações que compõem o que aqui estou entendendo como uma parte das margens do Estado na zona sul da cidade de São Paulo, assim como discursos, práticas, tensões e resistências que estarão presentes nos demais capítulos deste trabalho.

Enfim, esta é minha entrada na "sul" e a forma como a vejo: diversa, desigual e resistente. Assim como existem várias maneiras de entrar na região, existem também várias formas de observá-la. Esta é a forma como pretendo apresentá-la: a partir da perspectiva dos sujeitos, que não são apenas vítimas do processo de construção dessas margens sociais e políticas, mas também coparticipantes e protagonistas de possibilidades de resistência no cotidiano. 


\section{Capítulo 2 - As vozes sobre a periferia}

(...) Sem pretensão, a gente aqui do Capão nunca ia conseguir chamar a atenção do resto do mundo, porque da ponte João Dias pra cá é outro mundo, tá ligado? Eu nem sei o significado do nome Capão e nem por que seria Redondo.

Eu era bem pivetinho e já ligava o nome Capão Redondo a sofrimento, $80 \%$ dos primeiros moradores, ou quase primeiros, eram nordestinos, analfabetos. Gente muito humilde, sofredora, que gosta da coisa certa. Gente igual à minha mãe.

(...) São Paulo massacra os mais pobres e aqui no extremo sul eu senti na pele o que é ser preto, pobre, filho de mãe solteira negra, que veio da Bahia com doze anos de idade. Aprendi a não gostar de polícia, sei o que é andar muito loko três, quatro dias direto e nem por isso atravessar o caminho de ninguém.

No Capão Redondo é onde a foto não tem inspiração pra cartão-postal. Os turistas não vêm gastar os dólares e os poetas nunca nem sequer ouviram falar, pra citar nos sambas-enredo. Capão Redondo é a pobreza, injustiça, ruas de terra, esgoto a céu aberto, crianças descalças, distritos lotados, veículo do IML subindo e descendo pra lá e pra cá, tensão e cheiro de maconha o tempo todo.

(...)São Paulo não é a cidade maravilhosa, e o Capão Redondo no lado sul do mapa, muito menos. Aqui as histórias de crime não têm romantismo e nem heróis.

Mas, aí! Eu amo essa porra!

- Mano Brown, Testemunho Capão - A número 1 sem troféu

Por que a zona sul de São Paulo é a pior zona? Nós tivemos um processo histórico de ocupação na cidade de São Paulo em meados da década de 1980 que foi muito prejudicial ao desenvolvimento. Por quê? Porque as pessoas invadiram áreas de manancial de forma totalmente desordenada. $O$ poder público não podia chegar lá pra prestar os seus serviços, os seus produtos, enfim, a oferta de serviços públicos: você não podia construir uma creche, não podia construir uma escola. Todo o sistema de transporte público naquela região foi muito prejudicado. A gente brinca que é uma região da cidade onde o ônibus não faz a curva. E por que não faz a curva? Porque são ruas estreitas, ruas apertadas, ocupação totalmente desordenada. E a região sul concentra tudo isso porque o poder público demorou muito tempo pra se convencer de que, ainda que fosse área de manancial já invadida, ele tinha que ter presença sob pena de nós termos lá uma anarquia e um caos social completo.

- Floriano Pesaro, Secretário de Assistência e Desenvolvimento Social,2005-2006. 


\section{Zona sul, uma periferia de São Paulo}

A zona sul de hoje é o resultado de tensões e de sobreposição de múltiplos deslocamentos, acomodações, violências e resistências. Esses processos e experiências estão nas narrativas de seus moradores, ativistas, artistas, pesquisadores e representantes do poder público, em forma de poesia, denúncias, histórias contadas no cotidiano, documentários, estudos etc. Tais narrativas, apesar de muitas vezes não coincidirem, não se excluem mutuamente. Pelo contrário, reforçam-se ou complementam-se, como fragmentos de um mosaico de trajetórias, memórias e discursos. Assim, a história da região, contada com orgulho por um descendente de imigrantes alemães que se instalaram na colônia alemã, uma das primeiras do Brasil, em Santo Amaro, não exclui a narrativa de moradores do Jardim Ângela sobre a partida dos Guaranis das margens da represa Guarapiranga devido à violência entre os grupos criminosos na década de 1980. Da mesma forma que não invalida relatos e estudos que demonstram a presença de pessoas negras desde o início do século XX na região, sendo inclusive o bairro de Santo Amaro reconhecido como um "local de esconderijo e fuga de escravos" (Carril, 2006, p. 111).

Minha intenção, neste capítulo, é apresentar essas múltiplas vozes da e sobre a zona sul. São memórias, dados, estudos que influenciam construções de discursos sobre a região. Discursos estes que podem não só ser mobilizados para justificar a intervenção do Estado no território e na vida de seus moradores, mas também ser agenciados pelos sujeitos que nela habitam para a construção de identidade e suas lutas de resistência. Como este trabalho trata dessas duas dimensões, considero relevante fazer uma breve passagem sobre as distintas interpretações da periferia e, mais especificamente, da zona sul.

De acordo com a historiadora Lourdes Carril, a região, até meados do século XX, era bem pouco povoada. O Capão, por exemplo, era um bairro rural:

$\mathrm{O}$ próprio nome alude à presença de extensa cobertura vegetal, perfazendo mais de 50 quilômetros de circunferência. A exemplo dos arredores de São Paulo, a região era composta por caipiras produzindo gêneros agrícolas e, no caso específico da região de Santo Amaro, também vendiam madeira e carvão para construção e combustível para capital. (Carril, 2006; p. 114-115)

A população total dos distritos do Capão Redondo, Jardim Ângela, Campo Limpo, Jardim São Luis e Vila Andrade era de cerca de 23.000 habitantes na década de 1950. Esse 
número cresceu mais de dez vezes nos 20 anos seguintes, chegando a cerca de 245.000 na década de $1970^{35}$

Nos anos 1950, da Vila das Belezas até o colégio [adventista, no Capão Redondo] - uns 6 quilômetros, mais ou menos -, a gente contava nos dedos das mãos as casas que existiam tanto de um lado, quanto de outro. E a transformação foi muito rápida demais. (Edgardo, morador da região ${ }^{36}$ )

Tal crescimento foi resultado da chegada de milhares de migrantes atraídos pelo intenso processo de industrialização da metrópole. No caso da região sul, pela constituição do polo industrial de Santo Amaro, que passou a receber indústrias a partir da descentralização das fábricas que, antes, estavam concentradas nos bairros Mooca, Brás e Ipiranga.

Do lado de cá tinha muitas empresas metalúrgicas. O parque industrial era muito grande. Era um bairro operário. Não tinha asfalto, não tinha água encanada. Era carente de tudo. É através dessas lutas que as coisas vieram melhorando, com as lutas das associações da região (...) Um bairrodormitório, em que o povo só ia pra lá passar a noite mesmo. E de lá ia pra fábrica. Bairro extremamente carente e, pra vocês terem uma ideia, o primeiro esgoto encanado que entrou na região não só de M'Boi, mas também do Campo Limpo, foi em 1981, 1982... não, 1983! (Nivaldo, morador da região ${ }^{37}$ )

A saga dos migrantes é contada tanto pelos próprios moradores que viveram o processo, quanto também por seus filhos. As condições precárias da chegada, o trabalho árduo e comunitário da construção da moradia, a luta nos movimentos sociais, desemprego, violência etc. E tais histórias estão nos discursos de jovens ativistas ainda hoje. Discursos estes que hoje são elaborados em outros termos, tendo em vista os novos problemas sociais que afetam a periferia, o que pretendo tratar nos próximos capítulos.

A cidade de São Paulo, a partir da década de 1930, passou a ser o polo econômico mais dinâmico do país, atraindo imensos fluxos de migrações internas fortemente motivados pelo pleno emprego industrial promovido pelo milagre econômico. Esse contexto oferecia-se como alternativa às difíceis condições de vida enfrentadas no campo, sobretudo do Nordeste do país, afetado pela seca e pela mecanização da agricultura. A cidade passa então por um crescimento exponencial nos últimos 50 anos do século $\mathrm{XX}$, quando a população cresce em 5

\footnotetext{
35 Dados extraídos da página de informações da prefeitura de São Paulo: http://infocidade.prefeitura.sp.gov.br

36 Depoimento extraído do documentário Capão Redondo, Sintonia da Quebrada

37 Depoimento extraído do documentário História de M’Boi Mirim
} 
vezes, passando de 2 milhões em 1950 para 10 milhões em 2000 (Baeninger, 2011; Marques, 2010).

A acomodação desse novo contingente populacional foi se dando por um movimento de periferização e metropolização, principalmente a partir da década de 1970 (Marques, 2010). Isto é, as pessoas foram ocupando as franjas da cidade, assim como os municípios da região metropolitana de São Paulo, por se tratar de locais mais baratos de moradia. Assim, consolidou-se um padrão de ocupação do espaço da cidade, em que grupos sociais mais favorecidos alojaram-se nas regiões centrais e os grupos mais pobres, sendo compostos majoritariamente pela população negra e de origem migrante, nas áreas periféricas normalmente desassistidas de infraestrutura básica, como é o caso da zona sul.

Os pesquisadores acadêmicos estiveram sempre atentos a este processo. Os primeiros estudos centravam-se em análises estruturais com forte viés marxista, buscando entender a forma como se consolidava o capitalismo nos países periféricos. Trata-se de uma literatura fortemente engajada nas pautas políticas do desenvolvimento da América Latina, sobretudo nas décadas de 1960 e 1970. Grandes exclusões, fluxos migratórios, industrialização, desigualdade, marginalização, urbanização, dentre outras questões, eram o foco de tais análises (Kowarick, 2009).

Falava-se em "capitalismo excludente", isto é, o entendimento de que "mudanças significativas - diversificação e crescimento econômico, migração para as cidades e as oportunidades socioeconômicas e políticas que esses processos abriam - sempre deixavam de incorporar grandes parcelas nos benefícios do desenvolvimento e da modernização" (Kowarick, 2009, p. 68). Assim, combinava-se crescimento e pobreza, sendo a modernização e o desenvolvimento sempre incompletos, inacabados, elitistas e até mesmo "predatórios". No Brasil, então, estariam combinados elementos "arcaicos", "atrasados", "subdesenvolvidos" com as novas engrenagens produtivas que potencializavam a produção de riquezas:

Estas sociedades da periferia do capitalismo teriam leis gerais de acumulação inerentes ao desenvolvimento dependente periférico que reproduz antigas formas, ao mesmo tempo que produz novas modalidades de produção capitalista, estruturadas no pauperismo, desigualdade e marginalização, no subdesenvolvimento social e econômico. (Kowarick, 2009, p. 71)

Assim, a marginalidade não seria resultado do isolamento ou da exclusão de formas arcaicas das dinâmicas básicas da sociedade, mas, antes, "uma modalidade de inclusão intermitente, assessória, ocasional, marginal, porém integrante do processo produtivo" (Kowarick, 2009, p.73). A periferia seria, então, resultado desse processo. 
Aparentemente forjada pela ocupação espacial de forma irregular, espontânea e desordenada - como sugere o depoimento do Secretário de Assistência e Desenvolvimento Social, Floriano Pesaro-, a periferia teria sido produzida, para esta literatura, por uma lógica do Estado repressivo a fim de alicerçar o processo de acumulação de capital "caracterizado por reduzidos investimentos públicos em políticas e serviços básicos para a vida nas cidades, tais como saúde, saneamento, moradia e transporte coletivo, entre outros" (Kowarick; Marques, 2011, p. 10) - argumento que pretendo sustentar neste trabalho.

No entanto, tal literatura, embora ainda seja fundamental para se entender a dinâmica estrutural que continua produzindo a periferia, acabava de certa forma não só homogeneizando as regiões periféricas da metrópole, mas também contribuindo para sua estigmatização enquanto lugar de pobreza, ausência, violência e submissão, desprezando, assim, a enorme capacidade de organização política dos sujeitos que, desde os anos 1960, já estavam na luta por melhores condições de vida.

Essas lutas entram no debate somente a partir da década de 1980, quando os estudos começam a se voltar para as organizações populares que se multiplicam no contexto urbano, reivindicando melhores condições de vida. Como afirma José Gregório no documentário Capão Redondo, Sintonia da Quebrada:

[Há] uma luta de classes e comunitária. Uma luta séria em defesa dos trabalhadores por melhores condições de vida. Mas é luta mesmo, não é conversa fiada não. E o pau cantava na cabeça nossa, nós íamos presos, saía da cadeia e a luta continuava. Nós não desanimávamos não. Eu fui preso muitas vezes. A primeira cadeia minha foi em 1962 na luta pelo 13o salário, que é lei até hoje. E a luta continuou, nunca pode parar, nunca pode desanimar. Por isso é que estou aqui nesta casa há mais de 40 anos e continuo acreditando na luta. Sem luta não se consegue nada. Eu continuo lutando.

Na década de 1980 essas lutas se intensificaram na cidade, ocorrendo a emergência de uma intensa movimentação política, sobretudo por parte dos sindicatos e movimentos populares em regiões periféricas, visando melhorias de infraestrutura e direitos básicos. E na zona sul não foi diferente. A história dessas lutas ainda é viva na memória e narrativa das lideranças forjadas na época, elas sempre vêm à tona em reuniões ou mesmo em conversas informais com essas pessoas. Como o padre Jaime da Sociedade Santos Mártires nas reuniões 
do Fórum em Defesa da Vida no Jardim Ângela ou a Dona Neide, liderança da União Popular de Mulheres ${ }^{38}$, apenas para citar alguns exemplos.

Novamente conectados às pautas políticas, sobretudo a partir da efervescência em torno da abertura democrática, novos estudos emergem buscando entender o fenômeno. A periferia passa a ser considerada como possibilidade vanguardista de um novo projeto político que se expandia para além de suas fronteiras: partidos, eleições, governo, sindicatos etc. Kowarick e Marques observam que a maior parte desses trabalhos:

(...) teve implícita ou explicitamente um caráter apologético e dicotômico $($ Estado $=$ mal versus movimentos $=$ bem $)$, chegando a imputar aos movimentos sociais urbanos um papel político que jamais tiveram, ou seja, como protagonistas da liberação dos oprimidos e, em última instância, protagonistas também da superação das formas capitalistas de produção. (Kowarick; Marques, 2011, p. 12, grifos no original)

Mesmo que tais movimentos não tenham sido capazes de "protagonizar a liberação dos oprimidos", as análises demonstraram os resultados desses movimentos, sobretudo no que se refere à conquista de uma melhoria significativa de direitos básicos e infraestrutura urbana: queda da taxa de mortalidade infantil, aumento na expectativa de vida, diminuição nos índices de analfabetismo, maior proporção de crianças e jovens nas escolas, água, esgoto, coleta de lixo etc. Estas conquistas são contadas e recontadas por militantes que ainda estão por lá. Dona Maria narra orgulhosa como foi trabalhoso o processo de reunir "assinatura por assinatura" dos moradores para conseguir a instalação de uma creche na Vila do Sol. Assim como outras lideranças contam sobre a luta pela implementação do hospital de M'Boi Mirim, ou sobre o processo de desapropriação das terras do colégio adventista para a luta do movimento de moradia etc.

No entanto, afirma Friedman, nem essas lutas, nem as melhorias conquistadas, nem tampouco a abertura do regime democrático foram capazes de romper os padrões de segregação social que isolava grupos mais pobres em territórios segregados:

Depois de uma década de lutas e reivindicações, num contexto em que gradualmente consolida-se um sistema político democrático, deixa de ocorrer um enraizamento organizatório e reivindicativo que consolide um conjunto de direitos básicos. Eles podem estar na Carta de 1988, mas não se traduzem no fortalecimento de um campo institucional de negociação de interesses e na arbitragem de conflitos, nem em políticas sociais de alcance

38 Instituição forjada na década de 1970 a partir da luta de mulheres por direitos. Hoje, o foco são ações voltadas para mulheres, como atendimento de vítimas de violência, Casa do Idoso, Mova (Movimento de Alfabetização de Jovens e Adultos). Todas essas atividades são vinculadas à prefeitura por meio de convênios. 
massivo: não ocorreram processos que levassem à consolidação de uma condição de empowerment de grupos e categorias da sociedade civil. .(Friedman, 1992)

Em vez de ocorrer um "enraizamento organizatório" ou um fortalecimento de mecanismos democráticos para a efetivação de direitos, sucede não só um enfraquecimento de tais lutas, como também uma inserção subalterna desses atores sociais da periferia na política institucional, como demonstra Gabriel Feltran. $\mathrm{O}$ autor demonstra como, a partir da década de 1980 e, mais intensamente, na década de 1990, esses movimentos vão sendo absorvidos pela execução de serviços públicos das políticas sociais que foram ampliadas durante o período. Articulações locais e movimentos sociais começam a se institucionalizar, criando estruturas burocráticas internas e assumindo "convênios" com diversas instâncias do governo (Feltran, 2008).

Uma grande quantidade de serviços sociais, prestados sobretudo por instituições sociais que se multiplicam nesse contexto, passa a compor a presença do Estado na periferia, como tratado no capítulo anterior, constituindo o que começou a ser denominado como "gestão social" - isto é, organizações privadas atuando com ações de interesse público e, na maioria das vezes, com recursos públicos, inaugurando, assim, uma nova configuração entre Estado e sociedade:

Na virada do século, a corda estica. De um lado, tenta-se afrouxá-la pela ampliação das políticas compensatórias e de gestão da segurança, dos territórios e das populações, em geral na forma de convênios entre governos e organizações civis de base - muitas vezes antigos movimentos sociais para a implementação de "projetos sociais": profissionalização, apoio familiar, atividades culturais etc. De outro, amplia-se a repressão nas fronteiras, tensionando as margens de filiação social e política e fazendo emergirem nelas mais e mais "suspeitos". O encarceramento de jovens adultos das periferias de São Paulo cresceu quatro vezes desde meados dos anos 199039. (Feltran, 2010)

Vê-se assim a multiplicação de entidades sociais executando serviços públicos, sobretudo os de assistência social e creches, estabelecendo uma relação predominantemente hierarquizada e burocrática entre Estado e sociedade civil em vez da garantia de uma participação democrática de fato nas políticas, não apenas na execução, como também na elaboração destas. É o que Tiaraju D’Andrea chama de descenso das massas, ou o “fim de uma era de protagonismo para as classes populares baseada em organizações coletivas clássicas como os movimentos sociais, os partidos políticos de esquerda e os sindicatos"

39 A população carcerária do estado de São Paulo passou de cerca de 40 mil, em 1996, para mais de 150 mil, em 2008. Sobre a associação dos dispositivos assistencial e repressivo, ver Almeida, De Lucca e D’ Andrea (2009). 
(D'Andrea, 2013, p. 50).

No âmbito econômico também se agravavam mais as consequências das medidas neoliberais, como desemprego, privatizações, aumento da informalidade no emprego, queda nos salários:

Como síntese deste período, pode-se afirmar que à falta de representatividade política e ao descrédito nas instituições somaram-se os baixos salários e o desemprego em massa, que por sua vez se mesclaram ao individualismo utilitarista cada vez mais em voga e à privatização da vida e dos espaços públicos. Por sua vez, estas novidades, ao se incrustarem em bases assentadas em nossa sociedade e cuja origem são a escravidão e o autoritarismo, fizeram da década de 1990 um caldeirão explosivo no plano social. (D’Andrea, 2013, p. 54).

Esse "caldeirão explosivo" na zona sul é cada vez mais inflamado conforme a desigualdade se acentua. Algumas regiões dos distritos do Campo Limpo e Vila Andrade, que estão mais próximos ao Morumbi, passam a ser lugares de grande especulação imobiliária, onde começam a surgir condomínios de luxo e moradores com nível superior e em condições econômicas mais privilegiadas.

Isso ocorre devido ao surgimento de outro tipo de oferta de trabalho oferecido ali nesse período, não mais na indústria, mas sim no comércio. É justamente nessa época que se consolida o polo comercial da Berrini, em referência à avenida Engenheiro Luís Carlos Berrini, localizada do outro lado da marginal Pinheiros e que foi projetada no final da década de 1970 como uma alternativa de região empresarial, devido aos altos preços de aluguel nas proximidades da avenida Paulista. O que antes era barato, hoje é considerado o principal polo comercial de alto padrão da cidade. Talvez não seja por acaso que o distrito de Vila Andrade tenha tido um acréscimo populacional de $200 \%$ entre a década de 1990 e a década de 2010. Hoje, é uma das regiões que apresenta maior disparidade socioeconômica na cidade, concentrando o bairro nobre Panamby e a maior favela da cidade, Paraisópolis.

Isso sem mencionar as desapropriações e os incêndios que acontecem periodicamente nessas regiões, principalmente depois dos anos 2000. Conforme o site colaborativo Fogo no Barraco, que busca fazer levantamentos de incêndios na cidade, na região sul houve, entre 2005 e 2015, mais de 31 incêndios em favelas. Destes, 20 estão concentrados em regiões que sofreram valorização imobiliária, principalmente a partir de 2009: no Campo Limpo, cujo metro quadrado aumentou de $\mathrm{R} \$ 1.500$ para mais de $\mathrm{R} \$ 4.500,6$ incêndios foram registrados; e no distrito de Vila Andrade, em que o metro quadro chega a custar $\mathrm{R} \$ 7.000$, foram 
registrados 14 incêndios, quase todos na favela Paraisópolis, conforme mapa extraído do site 40

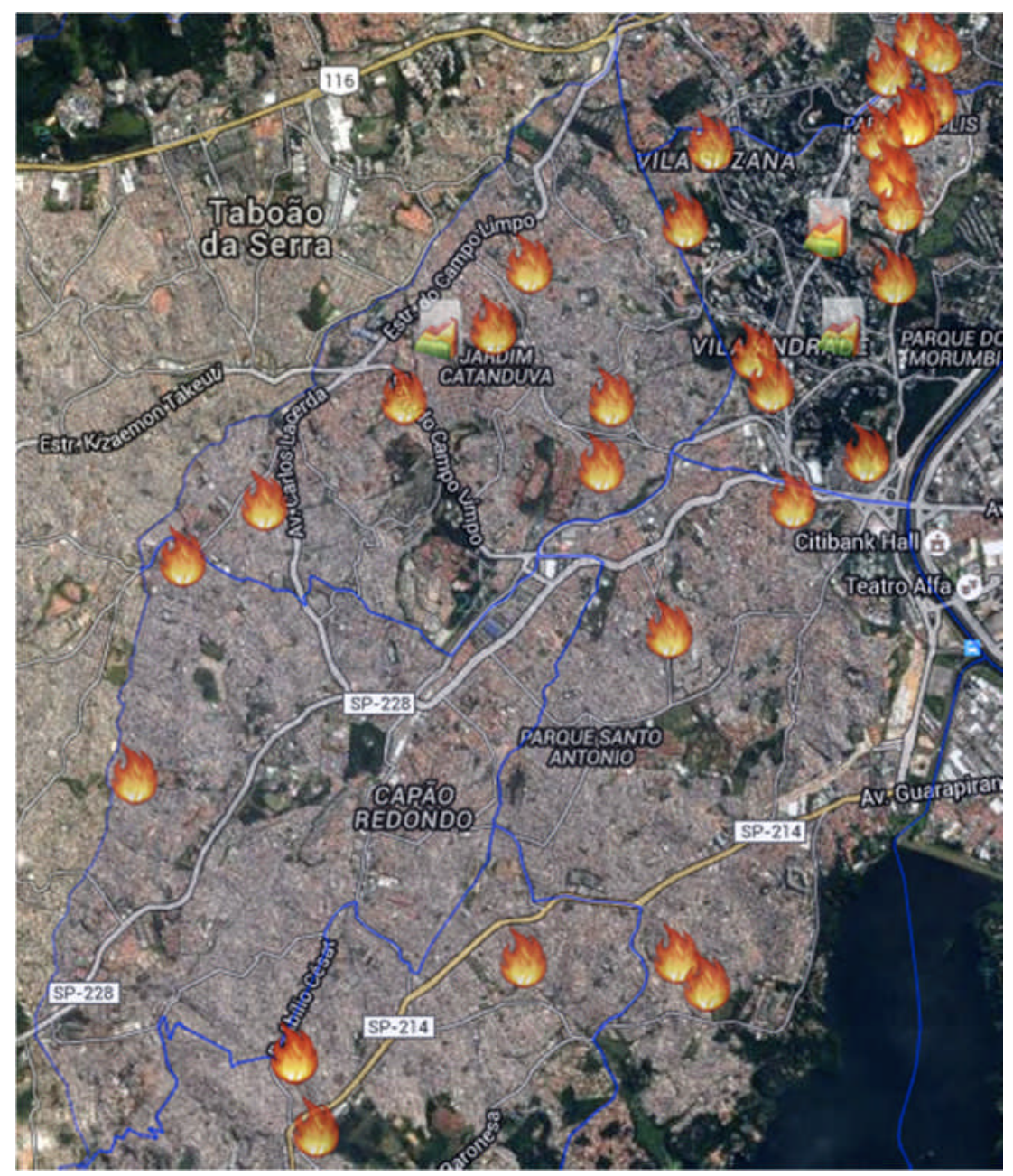

Ocorrências de incêndios em distritos: Vila Andrade, Campo Limpo, Capão Redondo, Jardim São Luís e Jardim Ângela (site - fogo no barraco)

De acordo com entrevista para a revista Carta Capital em junho de 2014, o jornalista Conrado Ferrado, produtor do documentário Limpam com Fogo, que trata de especulação imobiliária, incêndios e urbanização na cidade de São Paulo, fala sobre a "sutil" dinâmica dos incêndios nas regiões que passaram a ser valorizadas. Afirma que as construtoras e incorporadoras não "ascendem o fósforo" - pelo contrário, deixam queimar com o apoio do Estado:

Pense que um bairro que vem se valorizando está passando por muitas obras, que atraem mais interesses para essa região. Esses interesses envolvem coisas como melhorias de mobilidade, lazer e segurança - essa última quase sempre se traduz em uma vigilância sobre as favelas da região. Essa

40 http://fogonobarraco.laboratorio.us/ 
vigilância impede a consolidação dessas comunidades, que mantêm um caráter construtivo precário, com paredes de papelão e madeira e alta densidade de moradias, todos os fatores que contribuem para um grande incêndio. Não se trata de tacar fogo, mas de deixar queimar. (Ferrado, 2014, cf em www.cartacapital.com.br/blogs/speriferia/documentario-expoe-o-queesta-por-tras-de-incendios-nas-favelas-de-sao-paulo-7454.html41

Assim, a especulação imobiliária avança com uma aparente "ausência" do Estado no que se refere tanto à garantia de infraestrutura urbana adequada aos moradores das favelas, quanto à investigação dos incêndios. Continua Ferrado:

Quando começamos nosso trabalho já acontecia na Câmara dos Vereadores uma CPI sobre o assunto. Assim, acompanhamos as reuniões esperando que uma resposta do poder público surgisse dessa comissão. Porém, os primeiros meses de existência a CPI teve a maioria de suas reuniões postergadas por falta de quórum, o que lesou em muito as investigações. Os movimentos sociais pressionaram os vereadores participantes, mas mesmo assim os trabalhos não foram feitos à altura da importância do tema. O relatório final da CPI é extremamente vago e inconclusivo, dando como principal fator para o grande numero de incêndios o clima seco da cidade e sugerindo o fortalecimento de programas de combate aos incêndios nas comunidades programas que já existiam. (Ferrado, 2014, cf em www.cartacapital.com.br/blogs/speriferia/documentario-expoe-o-que-estapor-tras-de-incendios-nas-favelas-de-sao-paulo-7454.html 42

Como um dos nossos entrevistados diz, "foi pra inglês ver". Em nenhum momento os membros da CPI mostraram o interesse necessário para um tema tão importante - vale lembrar que estamos falando de um fenômeno que envolve mortes e deixa pessoas em condições de mendicância. Ao mesmo tempo, é interessante ver que todos os vereadores da CPI tiveram entre os patrocinadores de suas campanhas eleitorais empresas do setor imobiliário. Existe uma bancada do concreto em São Paulo, e ela não tem o menor interesse de que se investiguem temas como esse.

Quando Ferrado fala sobre vigilância, refere-se à polícia militarizada com uma atuação extremamente violenta na região, bem conhecida por seus moradores, sobretudo por ser responsável por grande parte dos homicídios de jovens.

Desde os anos 1990 esses distritos começaram a vivenciar a violência de forma mais dramática. Em meados desta década, os bairros da zona sul de São Paulo possuíam índices de assassinatos equiparáveis às regiões mais violentas da Colômbia ou de países em guerra civil. O Jardim Ângela chegou a ser considerado o mais violento do mundo pela ONU e, em conjunto com os bairros do Jardim São Luís e do Capão Redondo, conformou-se o que foi

\footnotetext{
${ }^{41}$ Cf. www.cartacapital.com.br/blogs/speriferia/documentario-expoe-o-que-esta-por-tras-de-incendios-nasfavelas-de-sao-paulo-7454.html

42 Ibdem
} 
denominado de "triângulo da morte", onde qualquer desavença corriqueira resultava em morte, para além dos conflitos entre traficantes e a polícia. Essa lembrança é trazida constantemente por aqueles de têm mais de 25 anos, como a familiaridade com os cadáveres nas ruas ou os relatos de familiares e amigos mortos.

Nos últimos dez anos, essas taxas têm diminuído de forma evidente. Segundo dados do SIM (Sistema de Informações sobre Mortalidade do Ministério da Saúde), houve uma queda de 82,2\% nos índices de homicídios entre 2000 e 2011, baixando de 51,1 para 9 mortes por 100 mil habitantes.

No entanto, em relação aos últimos cinco anos, se observarmos de perto, essa taxa é relativa. Entre jovens negros e em territórios periféricos a violência voltou a subir. Tais índices não são igualmente distribuídos pelos distritos da capital, nem por faixa etária e sexo. O distrito do Campo Limpo assume o 1o lugar na taxa de óbitos de jovens do sexo masculino com idade entre 15 e 29 anos - 82,37 por 100 mil habitantes nessa mesma faixa etária. $\mathrm{O}$ distrito do Jardim Ângela ocupa a 2a posição - 71,68 -, o distrito do Jardim São Luís, a 5a 50,36 -; o distrito de Capão Redondo, a 9a - 47,12 - e o distrito da Vila Andrade, a 7a $49,44^{43}$. Esses distritos fazem parte da mesma região, embora pertençam a subprefeituras diferentes. Isso significa que se trata de uma região em que se encontram 4 dos 10 distritos com maior taxa de homicídio de jovens do município.

Paula Miráglia, analisando os homicídios ocorridos no ano de 2003, constata que $85,5 \%$ das vítimas conhecia seus executores e em quase todos os casos morava ou frequentava os mesmos lugares, chegando à conclusão de que os crimes faziam parte de histórias do cotidiano de seus autores e vítimas:

Cometer um homicídio, além de evidente privatização dos meios de resolução de conflitos, pode ser lido também como parte de um processo de interação entre pessoas. Nesse caso, porém, como se trata de um crime cujo resultado é a morte, há um processo dramático de interação entre um autor de um lado e uma vítima de outro. Matar ou praticar a violência parece então se converter numa forma de sociabilidade. (Miráglia, 2007, p. 96)

No entanto, se observarmos os dados atuais, os homicídios parecem indicar mais do que uma forma de resolução de conflitos ou de sociabilidade local. Várias são as denúncias e indicadores que confirmam um significativo aumento dos homicídios cometidos pela polícia, principalmente a militar, cujas as vítimas são sobretudo jovens negros e moradores das periferias da cidade. Os dados exatos das mortes e dos responsáveis são ainda muito controversos. Mas, periodicamente, surgem levantamentos que demonstram essa tendência.

\footnotetext{
43 Fonte: www.nossasaopaulo.org.br
} 
O telejornal SPTV da TV Globo, considerado "aliado" ao governo do Estado, produziu uma matéria que foi ao ar em março de 2016 demonstrando que uma em cada quatro pessoas assassinadas no município foi morta pela polícia. Os dados foram coletados a partir do acesso que o programa teve a mais de quatro mil boletins de ocorrência via Lei de Acesso à Informação $^{44}$. O levantamento demonstrou que $26 \%$ dos 1.591 assassinatos ocorridos na cidade foi cometido pela polícia. O mapa a seguir indica os assassinatos ocorridos na cidade diferenciando homicídios, latrocínios e violência policial.

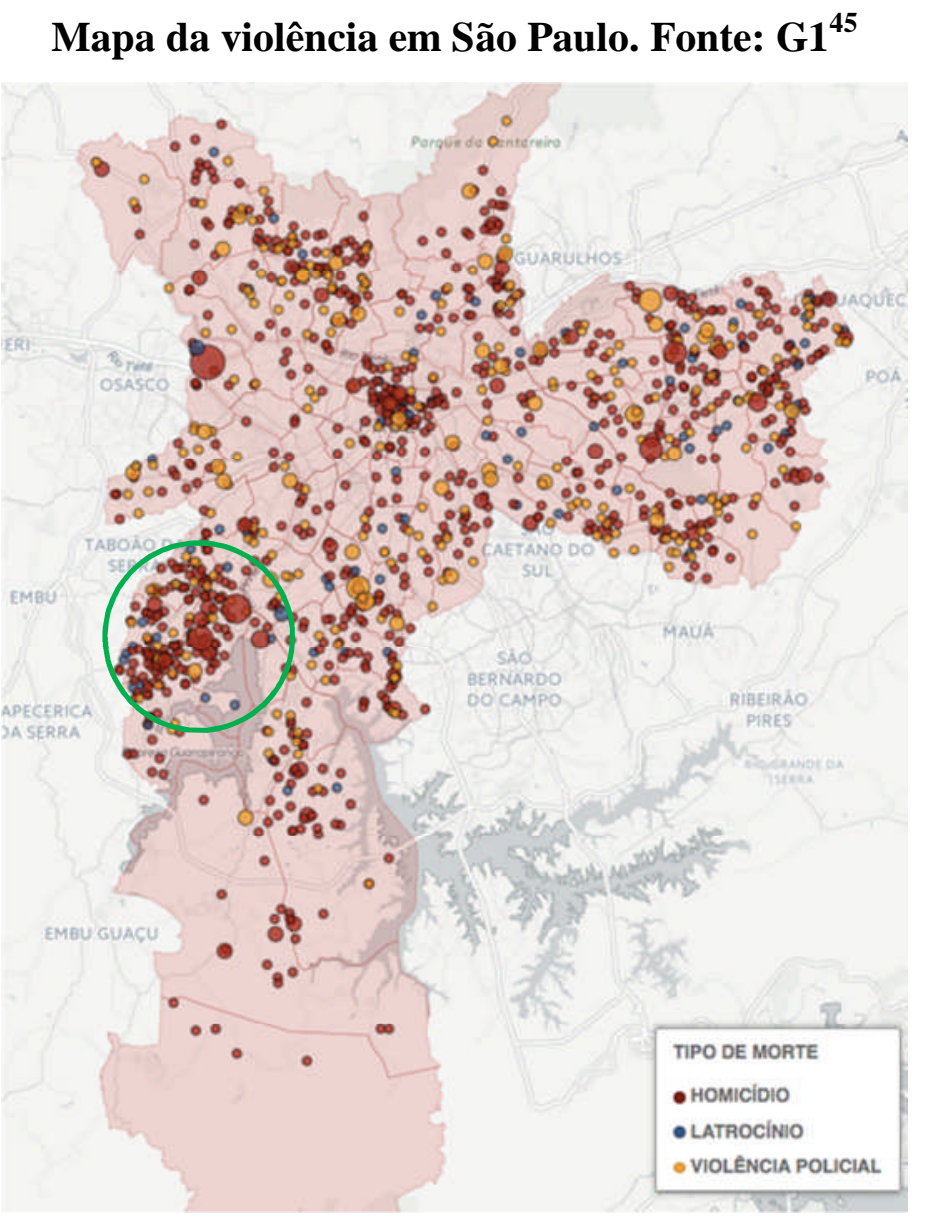

É importante observar no mapa como se destaca a concentração de mortes na região em que estão os distritos da zona sul (destacados pelo círculo verde) em comparação ao restante do município. Não pretendo me aprofundar na discussão sobre os homicídios: minha

\footnotetext{
${ }^{44} \mathrm{~A}$ lei $\mathrm{n}^{\circ}$ 12.527/2011 regulamenta o direito constitucional de acesso às informações públicas. Essa norma entrou em vigor em 16 de maio de 2012 e criou mecanismos que possibilitam a qualquer pessoa, física ou jurídica, sem necessidade de apresentar motivo, o recebimento de informações públicas dos órgãos e entidades

45 http://g1.globo.com/sao-paulo/noticia/2016/04/uma-em-cada-4-pessoas-assassinadas-em-sp-foi-morta-pelapolicia.html
} 
intenção é a de evidenciar a existência dessa problemática em torno da qual cada vez mais ativistas e movimentos sociais têm se articulado, denominando-a como "extermínio" ou "genocídio" de jovens ou "do povo negro, pobre e periférico", de que tratarei no capítulo 5.

A violência do Estado também se constitui como um questão importante para quem estuda a periferia, tornando-se, afirma Vera Telles, uma "evidência incontornável" para quem pesquisa tais territórios. Assim, endurecimento penal, violência policial, extermínios, encarceramento em massa passaram a significar não apenas tópicos interessantes de pesquisas, mas sobretudo o cerne da produção das margens, nas circunstâncias concretas de vida e trabalho dos que habitam a periferia (Telles, 2013).

Dessa forma, percorrendo a bibliografia analisada, percebe-se que a partir dos anos 1990 vai sendo consolidada uma nova forma de gestão da violência e da pobreza, tendo em vista garantir a sustentação e o desenvolvimento do capitalismo no meio urbano. Segregação espacial da pobreza e ação efetiva do Estado nesses territórios - a partir da polícia e da gestão social, no sentido de reprimir e normatizar seus moradores - são ingredientes do processo de produção das periferias. Isso gera, assim, o que Kowarick chama de condição de subcidadania urbana:

[A condição de subcidadania urbana] é importante para fundamentar uma
forma de controle social pela vistoria da vida privada das pessoas: o mundo
da desordem, potencialmente delinquente, é jovem (...) de preferência não
porta ou não tem carteira de trabalho e mora nos cortiços das áreas centrais
ou nas favelas das periferias. Sobre esta modalidade de moradia, o
imaginário social constrói um discurso que esquadrinha a mistura de sexos e
idades, a desorganização familiar, a moradia duvidosa, os hábitos
perniciosos, olhando estes locais como focos que fermentam os germes da
degenerescência e da vadiagem e daí o passo para a criminalidade. Ou seja: a
condição de subcidadão como morador das cidades constitui forte matriz que
serve para construir o diagnóstico da periculosidade. (Kowarick, 2000, p. 54)

A construção do diagnóstico da periculosidade justifica uma ação violenta do Estado que, inclusive, ultrapassa os limites legais. Como é o caso da quase "ausente comoção social" frente às altas taxas de homicídios de jovens, frequentemente justificadas como "confronto policial" mas que se tratam, evidentemente, de execução.

No entanto, os moradores da periferia não estão passivos sob a imposição violenta do Estado. Como já tratado neste capítulo, os agenciamentos e as resistências de seus sujeitos são tão antigas quanto sua própria constituição. Assim, se, por um lado, durante os anos 1990 aqueles movimentos sociais que foram fundamentais nas lutas por direitos nas décadas de 1970 e 1980 acabaram por se institucionalizar e assumir uma condição marginal na política (Feltran, 2010; D’Andrea, 2013), foi também nesta mesma década, por outro lado, que 
começaram a surgir novas vozes não só denunciando as condições de vida na periferia, mas também começando a forjar um novo discurso a fim de reelaborar uma "identidade periférica" (Peçanha, 2012; D’Andrea, 2013).

Nisso o movimento hip hop foi fundamental. Na zona sul surge o Racionais MC's, considerado o mais importante grupo de rap da cidade, como mencionado no capítulo anterior. Mas podemos citar muitos outros grupos e artistas que, ao longo destes mais de 25 anos, surgiram na região com linguagens diversificadas, tentando reelaborar identidades e expor injustiças sociais.

Buscando observar esse novo fenômeno, surge um conjunto de estudos que procura focalizar nessas novas manifestações de resistência, ligadas predominantemente a linguagens culturais. Essas manifestações emergem na década de 1990, multiplicando-se e diferenciandose com o passar do tempo, como o movimento hip hop, seguido pelo surgimento de saraus e, posteriormente, de coletivos de jovens de teatro, dança, comunicação etc., todos compartilhando e fortalecendo uma identidade racial e de pertencimento à periferia.

Ocorre não só a apropriação do termo periferia para designar uma identidade positivada, mas também uma multiplicação dos atores sociais, sobretudo coletivos artísticos juvenis que passam a se firmar como um distinto campo discursivo, lançando outras referências e outras figurações da cidade de São Paulo (D’Andrea, 2013, p. 43). Campo discursivo esse que segundo Tiaraju Pablo D'Andrea contribui para elaborar uma nova subjetividade destes sujeitos periféricos oferecendo referências para explicar seu lugar no mundo e fundamentar sua existência, diz o autor:

A narrativa criada por essa população foi aquela expressa por um movimento cultural que soube condensar expectativas e sentimentos da população periférica. A principal expressão desse movimento é o grupo de rap Racionais $\mathrm{MC}^{\prime}$ s. Por outro lado, surgiu uma nova subjetividade por meio de uma intensa luta para se colocar no mundo e se perceber por meio do orgulho, e não do estigma. Quando o indivíduo portador dessa nova subjetividade age politicamente é denominado neste trabalho como sujeito periférico. (D’Andrea, 2011, p. 16).

Érica Peçanha Nascimento já sinalizava em seu estudo sobre a Cooperifa, um importante sarau realizado no Jardim São Luís que influenciou diversos escritores da região, para essa construção positivada de identidade "periférica". Assevera:

A afirmação territorial e identitária da periferia permite que os moradores desse tipo de espaço social, na posição de artistas e ativistas, agenciem novos lugares para si, para além das relações habituais com a vitimização, pobreza e violência. Dessa forma, as noções de periferia construídas por 
esses sujeitos, mesmo que passíveis de disputa, produzem mudanças não apenas no modo como seus moradores são rotulados, mas também na maneira como esses moradores - na posição de poetas, artistas e ativistas pensam a si mesmos e se relacionam com o contexto mais amplo. (Peçanha, 2011)

Assim, a periferia foi e continua sendo produzida a partir do avanço da acumulação de riquezas na metrópole sustentada pela ação do Estado - seja a partir de sua omissão no que se refere à promoção de direitos e à proteção da população pobre, seja por protagonizar ações violentas no sentido de reprimir, normatizar e controlar esta população. No entanto, ela também não deixa de ser produzida pelos sujeitos que a constituem, os quais, a partir da experiência da opressão e da agência no cotidiano, produzem identidades e lutas sociais.

\section{A zona sul em dados e taxas}

As estatísticas oficiais referentes à zona sul reafirmam a condição de desigualdade com relação às regiões mais centrais da cidade - os dados ficam mais compreensíveis se apresentados sempre em relação a este centro. Começando pela densidade populacional, hoje as duas subprefeituras, a do Campo Limpo e a do M'Boi Mirim, concentram 1.186.829 habitantes, $10 \%$ do total da população do município, em uma extensão territorial que representa 5,7\% da cidade, o que faz desta uma das regiões mais populosas de São Paulo. Jardim Ângela, Capão Redondo e Jardim São Luís estão entre os dez distritos mais populosos da cidade: 3a, 5a e 6a posições, respectivamente - o Campo Limpo não fica muito abaixo, assumindo o 12 o lugar.

Tal densidade populacional vem acompanhada pela concentração de moradores de baixa renda e pela a presença de muitas favelas. Esses distritos apresentam as maiores porcentagens de domicílios em favelas: Capão Redondo, com a 5a maior porcentagem 26,74\% -; Jardim São Luís, com a 6a - 25,59\% -; Campo Limpo, em 9o lugar - 23,87\% - e Jardim Ângela, na 17a posição - 17,35\%. O município de São Paulo tem porcentagem média de 10,8\% de domicílios em favelas e, em distritos como Moema, Itaim Bibi ou Santo Amaro, tal porcentagem não chega a $1 \%$.

Com relação à renda, do total de 314.502 pessoas responsáveis por domicílios, 57.359 não possuem rendimentos mensais e 53.558 possuem rendimentos mensais de até 1 salário mínimo. Isso significa que 35,26\% dos responsáveis, ou seja, quase 111 mil famílias, são

46 Fonte: www.nossasaopaulo.org.br 
chefiadas por pessoas sem rendimento ou com até 1 salário mínimo (IBGE: Censo 2010). Grande parte dos domicílios é chefiado por mulheres. E, além disso, a região oferece apenas 2,21\% do total de empregos formais da cidade de São Paulo, submetendo uma grande parte de trabalhadores da região a exaustivas viagens ao centro da cidade em transportes coletivos lotados. O tempo gasto do Fundão do Ângela para o centro da cidade pode chegar a 3 horas em horários de pico.

Nesses distritos, assim como em toda a periferia de São Paulo, está concentrada a grande maioria da população negra. As subprefeituras de M'Boi Mirim e Campo Limpo têm, respectivamente, $56 \%$ e $49,7 \%$ (a 2a e a 10a posições no ranking do município) de pessoas autodeclaradas negras dentre o total de moradores. Em comparação, os bairros de áreas centrais, como Pinheiros e Vila Madalena, possuem ,respectivamente, 7,3\% e 7,9\% de moradores autodeclarados negros.

Esses dados expressam um padrão de concentração da população pobre e predominantemente negra nas áreas periféricas que se consolidou nos últimos 30 anos, em grande contraste com o centro, onde estão as famílias em condições mais privilegiadas que se autodeclaram brancas. Não que a periferia seja homogênea em termos socioeconômicos - de fato, existem cada vez mais bairros de classe média e até zonas mais nobres nessa região. No entanto, a exceção explica cada vez mais a regra.

Isso fica evidente com o Mapa da Vulnerabilidade Social. Os distritos enfocados neste trabalho, assim como quase toda a periferia, apresentam índices de média e alta vulnerabilidade. Este mapa, produzido pela Secretaria Municipal de Desenvolvimento Social em parceria com o Centro de Estudos da Metrópole (CEM), tem por fim:

[Ser uma] bússola social que se vale das técnicas de georreferenciamento e permitir ressignificar o chão da cidade para orientar a instalação de programas sociais de enfrentamento da vulnerabilidade, da exclusão e da miséria, ampliando a acertada escolha de prioridades para as políticas sociais e econômicas direcionadas para a justiça social e a inclusão social. (Prefeitura da Cidade de São Paulo. Cf. em http://www9.prefeitura.sp.gov.br/sempla/mm/mapas/intro_vs.pdf)

Em sua produção foram consideradas algumas variáveis tidas como relevantes na caracterização de múltiplas dimensões da privação e da pobreza, tais como condições de habitação, renda, escolaridade, gênero, idade e estrutura familiar. 


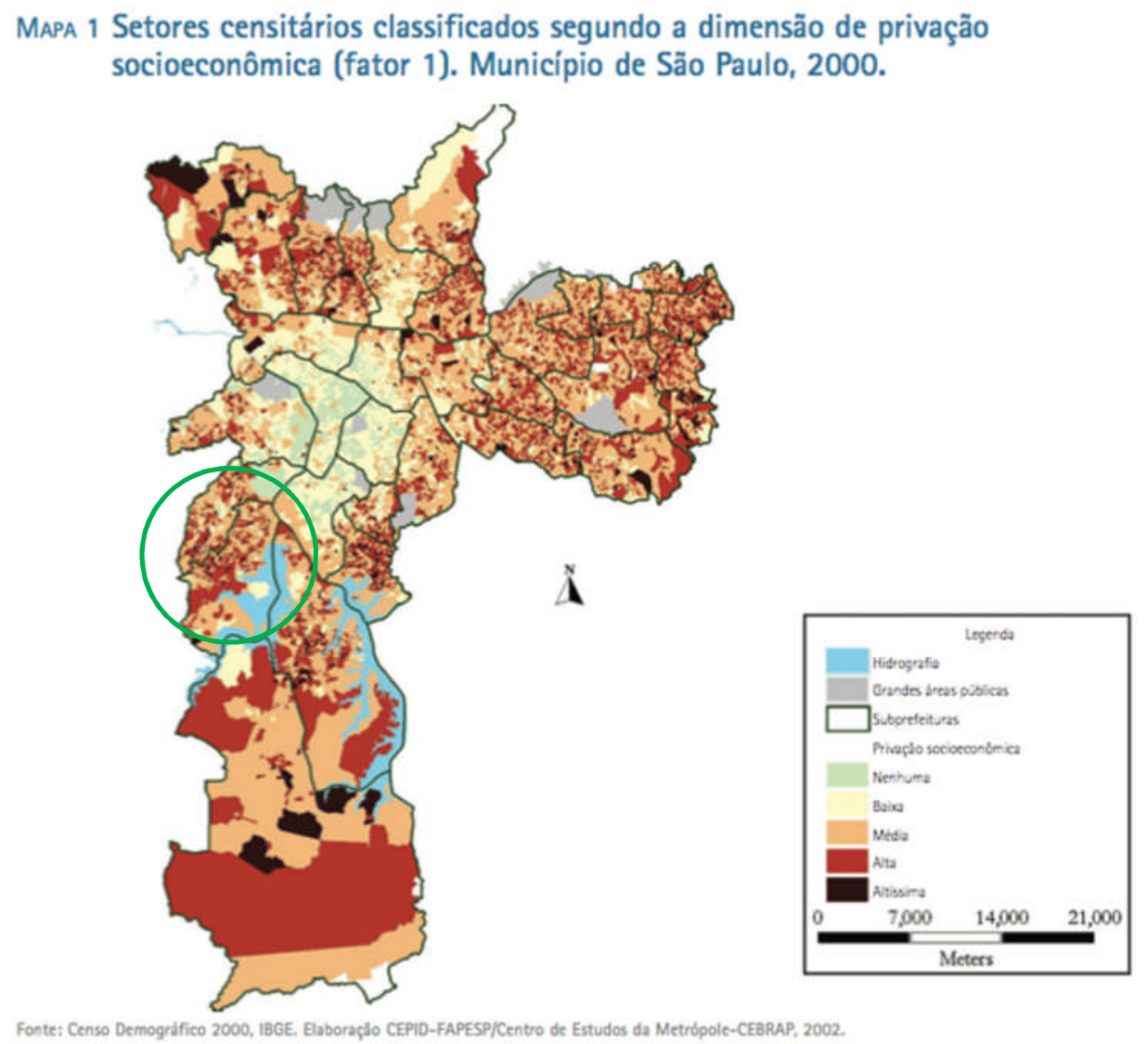

Embora o mapa demonstre uma heterogeneidade de taxas de vulnerabilidade na periferia, tal heterogeneidade oscila entre os níveis médio e alto, com pontos de altíssima e baixa vulnerabilidade. Este padrão de heterogeneidade não está presente em todo o município - ao contrário, a região central concentra as áreas com nenhuma ou baixa vulnerabilidade, circunscritas por regiões mais vulneráveis. Este mapa é mais uma expressão da discussão sobre o padrão de periferização e segregação que produz a cidade.

Talvez aqui seja oportuno retomar o argumento de Eduardo Marques sobre segregação. Para este autor, verifica-se na periferia uma grande heterogeneidade social, produzida sobretudo pela melhoria de condições sociais médias, mas combinadas com a manutenção de locais muito precários. Marques considera então mais coerente, hoje, falar em "periferias" ao tratar de territórios afetados pela pobreza urbana. Pobreza entendida aqui como um fenômeno multidimensional gerado por diversos processos sociais, os quais estão ligados à inserção econômica e social dos indivíduos. Tais processos, que são "supraindividuais" e "extraeconômicos", estão relacionados a enquadramentos culturais e a patamares de justiça aceitos socialmente que conformam os limites mínimos de bem-estar:

Compreender a pobreza de forma multidimensional nos permite enquadrar com maior plasticidade aqueles indivíduos que, apesar de conseguirem 
sobreviver, não têm acesso aos mais importantes benefícios das sociedades urbanas modernas. (Marques, 2010, p. 30)

Não utilizo estes dados para apresentar "uma realidade" da zona sul. Eles são completamente parciais e incapazes de expressar a dinâmica cotidiana tanto da desigualdade, quanto também da agência e das resistências de seus moradores. A própria seleção de quais dados deverão ou não ser captados pelas instituições de pesquisas deixa de fora uma quantidade infinita de recortes que poderiam construir outras interpretações da periferia. E elas não dizem nada em si mesmas, a quantidade de enquadramentos também pode ser múltipla.

Minha intenção, neste capítulo, foi a de organizar e expor algumas produções discursivas que sustentam a ideia de periferia: depoimentos de moradores que buscam resgatar a história da região a partir de suas próprias histórias; fragmentos da volumosa produção acadêmica que sempre esteve engajada com os processos políticos e sociais vividos pela periferia; e estudos estatísticos e indicadores sociais interessados em revelar condições econômicas e de vida na cidade, ressaltando os efeitos da desigualdade que recaem sobre as regiões periféricas.

Com isso, não procurei aqui definir a periferia, mas sim argumentar que tais produções discursas são interpretações possíveis que influenciaram a maneira como vejo a zona sul. 


\section{Capítulo 3 - Estado, violência e resistência}

A condição precária designa a condição politicamente induzida na qual certas populações sofrem com redes sociais e econômicas de apoio deficientes e ficam expostas de forma diferenciada à violações, à violência e à morte. Essas populações estão mais expostas a doenças, pobreza, fome, deslocamentos e violência sem nenhuma proteção. A condição precária também caracteriza a condição politicamente induzida de maximização da precariedade para populações expostas à violência arbitrária do Estado que com frequência não têm opção a não ser recorrer ao próprio Estado contra o qual precisam de proteção. Em outras palavras, elas recorrem ao Estado em busca de proteção, mas o Estado é precisamente aquilo do que elas precisam ser protegidas. Estar protegido da violência do Estado-Nação é estar exposto à violência exercida pelo Estado-Nação; assim, depender do Estado-Nação para a proteção contra a violência significa precisamente trocar uma violência potencial por outra. Deve haver, de fato, poucas alternativas. É claro que nem todas as violências advém do Estado-Nação, mas são muito raros os casos contemporâneos de violência que não tenham nenhuma relação com essa forma política.

- Judith Butler, Quadros de Guerra

A presença do Estado na periferia é múltipla, complexa e profundamente ligada aos processos sociais que a constituíram. Essa presença se dá muito mais na forma de omissões e repressão do que em efetiva e ampla promoção de direitos sociais. Por omissão podemos entender uma ausência intencional de ações que garantam a proteção dos seus moradores, como nos casos de incêndios vinculados ao avanço da especulação imobiliária, tal qual sugere o documentário Limpam com Fogo, mencionado no capítulo anterior; ou mesmo no que se refere ao atendimento a vítimas de violências, como familiares de jovens mortos, de que tratarei no quinto capítulo. Já a repressão está tanto na atuação violenta da polícia, quanto na prática cotidiana burocrática, normatizadora e punitiva de muitas políticas sociais.

Minha intenção neste trabalho não foi a de focar nas políticas de segurança, tampouco nas ações da polícia na periferia. No entanto, elas estão presentes ao longo do texto, pois fazem parte das trajetórias dos sujeitos desta pesquisa. Aqui, a preocupação é com as políticas sociais: seus sujeitos, instituições, documentos normativos, discursos e práticas. Pretendo demonstrar como tais políticas são orientadas por documentos normativos e leis altamente progressistas alinhados a compromissos internacionais, tais como: Organização das Nações Unidas (ONU), Comissão Interamericana de Direitos Humanos (OEA), Pacto Internacional 
sobre Direitos Civis e Políticos, dentro outros (Silva e Andrade, 2009). No entanto, os discursos e as práticas do cotidiano impõem o controle e a produção de estigmas, contribuindo assim para a reprodução de violências sociais (Kleimman, 2000).

Nestes mais de dez anos de ativismo e trabalho no campo da "gestão do social", observei diversas situações, trajetórias e casos que reafirmam meu argumento acima: muitos adolescentes em condições de abrigamento institucional - isto é, sob a tutela uma política que tem por fim proteger menores de 18 anos que estejam em condições de violência familiar, abandono ou pobreza extrema - que, uma vez institucionalizados, acabam sendo internados na Fundação Casa; ou, ainda, as inúmeras vezes em que a polícia é acionada para resolver conflitos em equipamentos públicos, tais como escolas e abrigos; apenas para apontar alguns exemplos.

Este capítulo, então, tem por objetivo apresentar algumas dimensões dessa presença estatal na periferia em forma de políticas sociais, bem como seus efeitos. Os quais estão relacionados não apenas à violência social que reproduzem, mas também às possibilidades de inserção profissional e institucional que oferecem aos moradores da periferia. Categorizando sujeitos, colocando-os em posições desiguais de poder, esta capilarização estatal passa a regular relações estabelecidas nos termos da burocracia das políticas sociais.

Vale ressaltar que a perspectiva teórica a partir da qual entendo o Estado não está necessariamente ligada aos cânones da ciência política ou da sociologia, que oscilam entre tratá-lo como um dado ou um instrumento de dominação e opressão de classes pelo capital isto é, como um reflexo da burguesia (Marx) -, por um lado, e como um aparato administrativo e político com o monopólio legítimo do exercício da violência (Weber), por outro lado, apenas para citar dois exemplos. Nesta dissertação, vejo o Estado como um modo de organização do poder e não uma instituição ou um bloco monolítico uniforme e impermeável. Tal modo de organização estabelece-se de forma hierárquica e preocupa-se com estruturas, códigos, protocolos, classificações, princípios e paradigmas. O Estado busca, assim, territorializar (Hoffman, 2011).

A forma de organização estatal do poder se impõe no sentido de normatizar a vida. Neste ponto, é importante retomar o argumento de Michel Foucault sobre biopoder e racismo de Estado. Segundo este autor, o Estado que "faz viver", que é responsável pela proteção e pela regulação da viva da população, também "deixa morrer". No entanto, o biopoder só pode “matar" em nome da proteção da população. Assim a morte, não somente física, mas também social, é apenas permitida a partir do racismo de Estado, que classifica aquele que poderá 
representar o "perigo biológico", levando ao "fortalecimento, diretamente ligado a essa eliminação, da própria espécie ou da raça” (Foucault, 2002, p. 306).

Aqui voltamos ao trecho do livro Quadros de Guerra, de Judith Butler, que abre este capítulo:

\begin{abstract}
A condição precária também caracteriza a condição politicamente induzida de maximização da precariedade para populações expostas à violência arbitrária do Estado que com frequência não têm opção a não ser recorrer ao próprio Estado contra o qual precisam de proteção. (Butler, 2015, p. 47)
\end{abstract}

Para Butler, todas as vidas são precárias, podendo ser eliminadas a qualquer momento de modo acidental ou proposital. No entanto, certas populações não têm sua precariedade reconhecida, não são reconhecidas necessariamente como vidas:

Essas populações são "perdíveis", ou seja, podem ser sacrificadas, precisamente porque foram enquadradas como já tendo sido perdidas ou sacrificadas; são consideradas como ameaça à vida humana como a conhecemos, e não como populações vivas que necessitam de proteção contra a violência ilegítima do Estado, a fome e as pandemias. (Butler, 2015, p. 53)

Aparentemente seria um contrassenso recorrer a essa discussão sobre o racismo de Estado em Foucault e sobre o "não reconhecimento de certas vidas como vida" em Butler quando nos referimos às políticas sociais. No entanto, o que observei e observo no cotidiano dessas políticas é não somente uma tentativa de controle e normatização dos sujeitos submetidos a elas, mas também a reprodução de práticas que "deixam morrer". E como isso se dá no cotidiano? Como as relações estabelecidas pela hierarquização e pela burocratização do Estado se impõem entre sujeitos que muitas vezes compartilham trajetórias semelhantes, diferenciando-os e estabelecendo relações de poder? E quais as possibilidades de resistência a essa imposição?

Neste capítulo, pretendo refletir sobre estas questões - sobre como o Estado se "territorializa" na periferia: expandindo-se e impondo-se como forma de organização do poder, redefinindo as relações, segmentando e classificando a população, reproduzindo a violência social. E, contudo, também promovendo direitos sociais, mesmo que de forma parcial e precária. Embora o poder se estabeleça de forma vertical, estas margens no cotidiano estão em constante movimento, a partir da tensão permanentemente provocada pela resistência e pela agência de seus sujeitos. 


\section{Ações do Estado na periferia}

A presença do Estado na periferia sempre foi uma reivindicação dos movimentos sociais, sobretudo a partir da década de 1980, em que lutava-se por melhores condições de vida: moradia, educação, saúde etc. Desde então, o que se tem observado são significativos avanços no que se refere à ampliação de direitos no campo normativo, principalmente após a constituição de 1988: o Estatuto da Criança e do Adolescente (ECA, 1990), a Lei de Diretrizes e Bases da Educação Nacional (LDB, 1996), a consolidação das políticas de assistência social, de saúde, bem como o relevo que vão ganhando as políticas de direitos humanos, apenas para citar alguns exemplos (Ribeiro e Castro, 2009).

No entanto, se considerarmos a efetivação concreta desses direitos recém-adquiridos, o processo é bem mais fragmentado, ambíguo e irregular, repleto de permanências de antigas formas de violação e até de mesmo retrocessos. Por exemplo, a universalização do ensino básico e a superação do analfabetismo foram acompanhadas pela ainda crescente precarização da educação pública (Ipea, 2009). Ou, ainda, por mais que a política de assistência social tenha se estruturado enquanto um sistema de proteção que tem como protagonista principal o Estado, sua execução é muito precária, repleta de práticas e discursos assistencialistas e até mesmo violentos no cotidiano. Isso sem contar os significativos progressos nas políticas de crianças e adolescentes e, mais recentemente, de juventude, acompanhados pela elevação das taxas de homicídio, encarceramento e internação de jovens.

Neste trabalho, não tenho a intenção de desprezar os avanços na efetivação de direitos sociais com a implementação dessas políticas na periferia. A luta pela ampliação e pela melhoria dos serviços ainda é constante. No entanto, tenho a intenção, neste capítulo, de ressaltar os efeitos dessa presença do Estado na periferia: não no sentido de uma avaliação da eficácia dos resultados das políticas, tendo em vista seus objetivos descritos em documentos normativos, mas sim observando os efeitos não previstos na consecução desses objetivos ou, dito de outro modo, os efeitos "secundários".

Além disso, pretendo demonstrar como essas políticas sociais, a partir dos casos que analisei da Medida Socioeducativa em Meio Aberto ${ }^{47}$ e do Plano Juventude Viva ${ }^{48}$, não tratam dos "problemas sociais" como questões que tenham causas sociais, de maneira a

\footnotetext{
${ }^{47}$ Serviço oferecido pela Secretaria de Assistência Social e prevista no ECA que tem por fim desenvolver atividades socioeducativas a adolescentes que cometeram ato infracional e estejam cumprindo Liberdade Assistida e Prestação de Serviços à Comunidade.

${ }^{48}$ Plano criado pelo governo federal - pela Secretaria de Juventude e pela Secretaria de Políticas de Promoção da Igualdade Racial - que visa a "prevenção" de homicídios de jovens.
} 
conduzir à reflexão e propostas de ações que possam intervir nas causas desses problemas. Pelo contrário, tais políticas tendem a voltar suas ações para um "público-alvo" e suas famílias, visando a inserção social precária desses sujeitos e não questionando as possibilidades reais de inserção. Sendo assim, atos infracionais ou homicídios de jovens seriam problemas de inadequação dos sujeitos na "inserção social", o que requereria a normatização dos mesmos, sobretudo de suas famílias. Vale ressaltar a tendência atual das políticas sociais em tomar a família, e não o indivíduo isoladamente, como unidade de atendimento (Sarti, 2004). Tais processos de normatização estão saturados de práticas violentas e punitivas.

Além disso, conforme afirma Cyntia Sarti, há uma tendência em se desqualificar os discursos dessas famílias por parte dos profissionais quanto mais elas pertencem a estratos sociais mais baixos, "reproduzindo os mecanismos que instituem a desigualdade social" (Sarti, 2008, p. 46).

Essa solução pela normatização e pelo controle de populações pobres tem como consequência a ampliação da institucionalização dos sujeitos: crianças e jovens abrigados durante anos, internações na Fundação Casa, cumprimento de medidas socioeducativas em meio aberto, acompanhamento da família por assistentes sociais, prisões, escolas em período integral etc. Com isso, esparrama-se pela periferia uma extensa malha de instituições governamentais e não governamentais que oferecem um espaço em que a relação entre sujeitos começa a se estabelecer em termos de "técnicos" e "atendidos". Tal malha institucional constitui-se como um significativo mercado de trabalho e meio de construção de carreiras profissionais para os próprios moradores da periferia.

Essas questões começaram a surgir a partir do momento em que fui capaz de olhar para o meu campo de trabalho e ativismo, e até mesmo para a minha própria trajetória, com o olhar de antropóloga. Isto é, comecei a perceber como trajetórias de diversas pessoas, inclusive a minha, foram forjadas a partir dessa relação/interface com setores do Estado. Quase todas as pessoas com quem convivo em lugares de trabalho e ativismo na periferia completaram sua educação básica em escolas públicas. Muitas delas, inclusive, tornaram-se docentes da rede pública ou profissionais dos equipamentos públicos e ONGs locais.

Assim vão se formando professores, psicólogos, assistentes sociais, educadores, arteeducadores etc., que vão encontrando, com sua formação acadêmica, lugar nos equipamentos públicos e nas instituições sociais presentes no território. A presença cada vez maior de institucionalização dos movimentos sociais e da implementação das políticas vai promovendo 
crescente hierarquização e segmentação de papéis, definindo novas bases de relação com a população local.

Se nos movimentos sociais as relações eram estabelecidas a partir de uma relativa igualdade, a institucionalização desses movimentos estabelece conselhos, diretorias, coordenações. O avanço das políticas sociais com técnicas cada vez mais elaboradas vai criando um novo vocabulário com o qual essas instituições devem lidar (Feltran, 2008), sem contar as especificidades de serviços e de públicos atendidos: políticas de crianças e adolescentes, de jovens, dos idosos, de pessoas com deficiência, voltadas à população negra, LGBTT, da mulher etc., as quais se desdobram em múltiplos equipamentos públicos por meio dos quais tal público é "atendido": Cras, Creas, escolas, abrigos, UBSs. Estabelece-se com a "população local" relações de "público atendido", reguladas por uma quantidade gigantesca de documentos normativos, legislações e burocracias que estabelece o início e o fim da relação, isto é, "atendimento" ou "vínculo" (Feltran, 2008).

Os sujeitos, no entanto, também começam a se articular em torno das lutas desses segmentos: núcleos de mulheres, movimentos LGBTT, coletivos de jovens etc. Se, por um lado, os movimentos sociais reivindicam políticas para suas demandas, tais políticas acabam também por forjar novos movimentos sociais, que se reinventam com novas demandas a partir dos efeitos dessa própria política - é o caso do Plano Juventude Viva, tratado no capítulo 5.

Minha intenção aqui não é a de construir uma crítica às políticas sociais, mas sim expor o que venho observando no cotidiano dessas políticas, mais especificamente nas Medidas Socioeducativas em Meio Aberto, nas de assistência social e no Plano Juventude Viva. Esse interesse surgiu a partir da desnaturalização desses lugares e dessas relações (público atendido, técnicos, gestores das políticas etc.) frente a meu contato com coletivos de jovens que operam em uma lógica mais horizontal e menos segmentada e que denunciam as violências ocorridas por meio dessas políticas sociais com as quais estão em permanente interface. Constroem um outro discurso, o de se "proteger do Estado", a ideia de "nós por nós".

Contrariando, então, a ideia de ausência do Estado, minha hipótese é a de que as ações públicas estão muito mais presentes - ou, ao menos, presentes de forma diversa - na paisagem e no cotidiano da periferia do que nas regiões centrais. Se, por um lado, os equipamentos públicos de cultura - como centros culturais, museus e teatros - estão 
concentrados nas regiões centrais, nas regiões periféricas, por outro lado, encontramos as maiores taxas de homicídios atribuídos à polícia militar ${ }^{49}$.

Uma comparação pode ser feita a partir dos equipamentos de educação. Enquanto os índices de matrículas em Ensino Fundamental e Médio oferecido por escolas públicas é de 90\% em M'Boi e 79\% em Campo Limpo, em Pinheiros, distrito em que se localizam bairros nobres da cidade, a porcentagem é de $31 \%$, frente a $69 \%$ de matrículas na rede privada. Devese levar em consideração que muitas das matrículas em escolas públicas neste distrito são de filhos de trabalhadores que estão empregados na região, mas moram em bairros mais afastados. O gráfico abaixo ilustra estes dados.

Número de matrículas (rede pública e privada) em escolas públicas e privadas nas subprefeituras de M'Boi Mirim, Campo Limpo e Pinheiros ${ }^{50}$

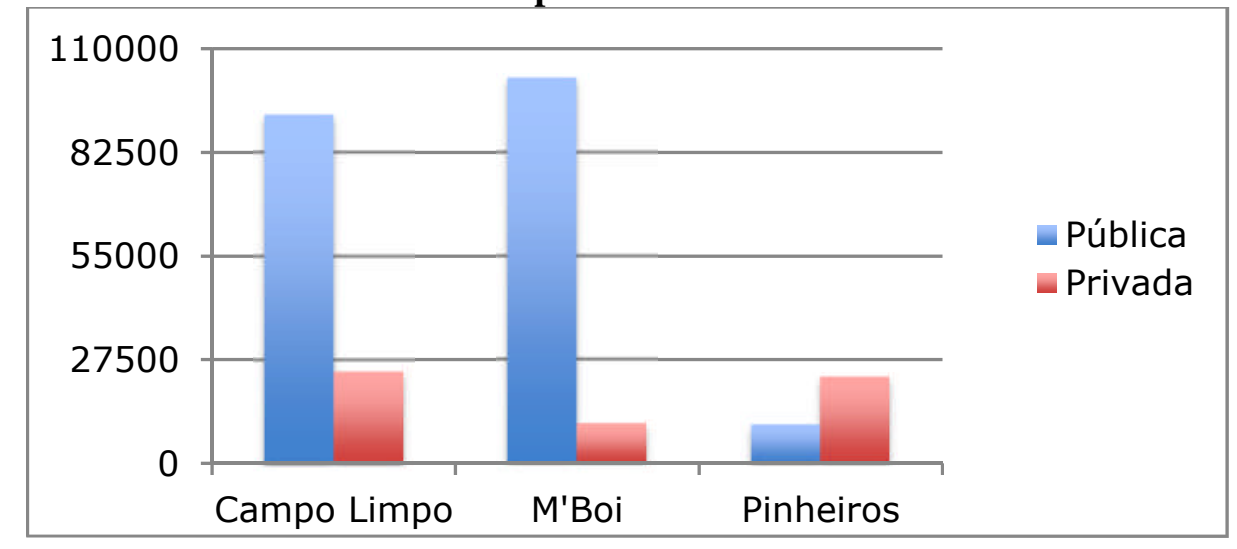

Considerando os serviços das políticas de saúde, assistência social e educação, tanto de execução direta (serviços prestados por funcionários públicos em equipamentos e com recursos públicos) quanto de execução indireta (executados ou geridos por instituições da sociedade civil contratadas pelo governo), somam-se mais de 400 unidades nas subprefeituras de M’Boi e Campo Limpo. Não pretendo afirmar com isso que o atendimento público das políticas sociais seja suficiente tanto em quantidade como em qualidade. Os depoimentos dos moradores indicam exatamente o contrário: filas de espera nas creches por mais de dois anos; salas escolares superlotadas; episódios de violência em todos os equipamentos; maus tratos em hospitais; horas intermináveis em espera nos prontos-socorros etc.

\footnotetext{
${ }^{49} \mathrm{Cf}$. http://g1.globo.com/sao-paulo/noticia/2016/04/uma-em-cada-4-pessoas-assassinadas-em-sp-foi-mortapela-policia.html

${ }^{50}$ Dados extraídos do site da prefeitura de São Paulo: http://infocidade.prefeitura.sp.gov.br/
} 
O que pretendo é afirmar que existe de fato uma presença do Estado na periferia, seja a partir das políticas sociais, precárias e insuficientes, seja a partir da violência ou pela própria omissão. Seus moradores, sobretudo aqueles nascidos depois da década de 1980 com a universalização de diversas políticas, têm suas trajetórias marcadas por essa presença. Não é raro observar pessoas que concluíram o ensino básico em escolas públicas e tornaram-se professoras - às vezes, da mesma escola em que estudaram. Ou, ainda, ver jovens que percorrem todo o "sistema de garantia de crianças e adolescentes": abrigos, Fundação Casa, Medidas Socioeducativas, Escolas Públicas, Centro de Juventude etc. É frequente encontrar jovens moradores da periferia que acessam políticas culturais, que são beneficiados pelo Prouni $^{51}$ ou, inclusive, estudam em universidades públicas.

A grande maioria das pessoas que conheci em meio a "gestão social" na zona sul possui trajetória semelhante: origem em famílias pobres, escolarização em instituições públicas, inserção profissional em políticas sociais locais e, não raro, algum ativismo em movimentos sociais ou coletivos. Essa também é a minha trajetória. Mesmo não tendo nascendo na periferia da cidade, venho de Mauá, cidade da região metropolitana com características bem semelhantes à zona sul.

Mauá é conhecida como cidade-dormitório. Suas poucas ofertas de emprego obrigam a maior parte da população a se deslocar para cidades do ABC (Santo André, São Bernardo e São Caetano) e para a capital. O trajeto é feito de trem, por meio da linha que liga Rio Grande da Serra à estação da Luz. Minha mãe veio do interior do estado para São Paulo ainda garota. Já meu pai nasceu na capital, filho mais velho de dez irmãos, que assumiu a família aos 18 anos, quando seu pai morreu. Era funcionário público de um hospital próximo à nossa casa, o Hospital Nardine, mais reconhecido como "açougue", devido à qualidade do atendimento oferecido. Minha mãe, operária de fábrica durante toda a vida de solteira, foi predominantemente "do lar" após o casamento, trabalhando apenas durante um período como "servente" na escola em que eu estudava, a Escola Estadual de Primeiro e Segundo Grau Walt Disney, umas das primeiras palavras que aprendi a escrever.

Concluí a educação básica em escolas públicas, inclusive o ensino médio profissionalizante em magistério. A partir dessa experiência, construí uma noção de que "não se deveria pagar por educação, esta deveria ser pública". Tanto que, quando fazia cursinho

\footnotetext{
${ }^{51}$ O Programa Universidade para Todos (Prouni) do Ministério da Educação, criado pelo governo federal em 2004, oferece bolsas de estudo, integrais e parciais (50\%), em instituições particulares de educação superior, em cursos de graduação e sequenciais de formação específica, a estudantes brasileiros sem diploma de nível superior que tenham estudado em escolas públicas ou em escolas particulares como bolsistas.
} 
pré-vestibular, pagar a mensalidade era muito incômodo para mim - não apenas por minha falta de dinheiro, mas também porque não achava aquilo "justo". A universidade pública era então minha única possibilidade, não só porque não teria condições de pagar por uma privada - pois na época ainda não existiam as políticas de acesso à universidade como o Prouni e o Fies $^{52}$-, mas também porque tinha uma forte convicção de que a educação era "dever do Estado".

Esta mesma convicção de dever do Estado também sempre me convocou para uma "responsabilidade social" que, no meu caso, se expressou através do ativismo. Desde que entrei na universidade, no curso de ciências sociais da USP, comecei a me engajar em movimentos sociais e a trabalhar com a "questão social”, começando, assim, minha atuação em ONGs e no Estado.

E foi compartilhando minha história em um encontro com técnicos do serviço de medida socioeducativa na zona sul, o Capão II, de que tratarei no próximo capítulo, que possuíamos trajetórias muito semelhantes e começamos a refletir sobre os "efeitos" da presença do Estado em nossas trajetórias. Estávamos eu, Andrea Arruda, ativista da região que trabalhou comigo no CDHEP, Sulamita Assunção, Elaine Lima e Fernando Silva, os três "técnicos" do serviço, que apresentarei mais detidamente no próximo capítulo. Aqui, pretendo destacar pontos desta conversa, em que pudemos refletir sobre a similaridade das trajetórias: ensino básico em escolas públicas, inserção precoce e precária no mercado de trabalho, interesse em atuar na "gestão social", escolha do curso de ensino superior vinculado a esta atuação mais "engajada" e ao ativismo.

Refletimos sobre como a presença de equipamentos públicos e esse campo de "gestão social" foram as condições concretas para a construção de nossas trajetórias: desde as questões mais objetivas, como oferta de emprego e possibilidades de construção de carreiras profissionais na periferia, até as mais "subjetivas", como uma noção de "espaço público", de “direitos e deveres" e possibilidades de engajamento.

Assim, pode-se dizer que a presença de uma de rede de equipamentos públicos e ONGs favorece uma promoção parcial de direitos e também a ampliação de oferta de trabalho para uma parcela dos moradores da periferia, sobretudo aqueles que concluíram a educação básica e alcançaram o ensino superior. No entanto, os efeitos podem ser outros para a população em "situação de maior vulnerabilidade", "público alvo" das políticas de assistência

\footnotetext{
${ }^{52}$ Programa do governo federal criado em 1999 e reformulado em 2010 para substituir o Programa de Crédito Educativo (PCE/CREDUC), que financia a graduação no ensino superior de estudantes que não possuem condições de arcar com os custos de sua formação.
} 
social, que acaba experimentando uma maior institucionalização de suas vidas, um maior controle e violência por parte do Estado.

A história de Bruno talvez nos ajude a refletir sobre essa condição. Desde os 9 anos de idade Bruno passou a viver em abrigos ${ }^{53}$. Foi deixado pelos pais, a quem nunca conheceu, com uma amiga da mãe, com quem viveu até ser entregue a uma tia, aos 6 anos, com quem morou até os 9 anos. Foi parar pela primeira vez em um abrigo (os atuais Saicas) pois a tia havia sido denunciada pelos vizinhos ao Conselho Tutelar por "beber demais". Até seus 17 anos, idade que tinha na data da entrevista, já havia morado em mais de cinco abrigos e sido uma vez internado na Fundação Casa ${ }^{54}$.

Conheci o Bruno quando ele era o foco de um "atendimento" do CDHEP. O objetivo desse atendimento era realizar um processo de Justiça Restaurativa junto a dois serviços públicos - o abrigo em que ele morava e o MSE Capão II - em que ele era atendido. Tais instituições estavam em conflito frente aos encaminhamentos que deveriam ser dados em seu caso. O abrigo avaliava o comportamento de Bruno como agressivo e aplicava sobre ele algumas punições, além de discordar dos relatórios do MSE, que descreviam que o adolescente estava "evoluindo" na medida socioeducativa. Frente a essa discordância, o MSE Capão II chamou o CDHEP para ajudar na resolução do conflito por meio da Justiça Restaurativa, pois esta instituição desenvolve projetos com tal metodologia visando apoiar os casos de "atendimentos" nos serviços públicos da região.

O processo de Justiça Restaurativa tem por fim construir espaços de diálogo, tendo em vista lidar com conflitos no sentido de restaurar os danos e as relações, prescindindo assim de instâncias superiores e de punição. Dessa forma, envolve os sujeitos implicados diretamente no conflito - no caso, Bruno e os educadores e técnicos de ambos os serviços. Com eles, são realizados diversos "círculos" de diálogo com o objetivo de entender o conflito, em que todos poderão "falar" a partir de suas perspectivas. O CDHEP acredita que as "práticas restaurativas" são ferramentas valiosas para reduzir as distâncias hierárquicas nos atendimentos das políticas sociais, bem como diminuir os casos de conflito com desfechos punitivos ou violentos nos atendimentos.

\footnotetext{
${ }^{53}$ Hoje denominados Saica (Serviço de Acolhimento Institucional para Crianças e Adolescentes em Situação de Vulnerabilidade e Risco Social), são serviços públicos da Secretaria de Assistência Social que, no município, são executados por instituições da sociedade civil a partir de convênios com o governo.

${ }^{54}$ A Fundação Centro de Atendimento Socioeducativo ao Adolescente (Fundação Casa/SP), anteriormente chamada Fundação Estadual para o Bem Estar do Menor (Febem), é uma autarquia fundacional (pessoa jurídica de direito público) criada pelo governo do Estado de São Paulo e vinculada à Secretaria de Estado da Justiça e da Defesa da Cidadania. Sua função é executar as medidas socioeducativas aplicadas pelo poder judiciário aos adolescentes autores de atos infracionais com idade de 12 a 21 anos incompletos, conforme determina o Estatuto da Criança e do Adolescente (ECA).
} 
Embora eu não pudesse participar dos círculos restaurativos, pois era vetada a participação de pessoas que não estivessem envolvidas no conflito, via a circulação das pessoas que dele faziam parte. E o que chamava a atenção era a ausência de qualquer pessoa que não fosse as dos serviços que atendiam Bruno. Os processos de Justiça Restaurativa contam com a participação de "pessoas de confiança" das pessoas envolvidas no conflito, vítima ou agressor, normalmente familiares ou amigos. No caso de Bruno, a pessoa de confiança era sua técnica de medida socioeducativa, indicando a construção de relações entre ela e o adolescente que ultrapassaria um "vínculo" padrão caracterizado por um relativo e cuidadoso distanciamente entre técnico e atendido. Nesse processo, Bruno também conheceu Marta, diretora do Cieja (Centro Integrado de Educação de Jovens e Adultos) ${ }^{55}$, já reconhecido por "acolher" jovens em liberdade assistida que normalmente são evitados pelas escolas. Marta também o apoiou durante os últimos anos, em que deixava o abrigo. Hoje, Bruno não está mais em medida nem no abrigo. Ele trabalha junto com a Marta no Cieja.

Mas a trajetória de Bruno não é marcada apenas por relações de apoio e "amizade" com os profissionais das políticas sociais. Sua história contada acima apresenta uma extensa institucionalização, controle e punição por parte de representantes de setores do Estado: aspectos presentes também no episódio de sua internação, desde o conflito desencadeador até o fim do cumprimento de sua "medida socioeducativa em meio fechado" :

Foi uma briga que teve no abrigo. Eu tive uma briga com um adolescente lá. A história foi que ele chegou bêbado, ele estava dormindo no quarto das crianças e não no dos adolescentes. A criança gritou à noite e eu fui no quarto para ver. Quando eu vi a cena estava a criança com as calças abaixadas e ele do lado, bêbado. Na hora eu fui para cima dele e machuquei ele. Aí chamaram a polícia. O policial perguntou porque eu fiz aquilo e eu expliquei para o policial. O policial disse que eu estava errado. Que a criança estava assustada porque eu tinha batido nele e não porque ele fez aquilo. E que era mentira minha. A educadora fez o boletim e depois de um mês tive a audiência e fui convocado.

Eu pensava que eles iriam me ouvir, não a meu favor, mas pela criança, porque naquele momento era a criança que estava passando por dificuldades ali. Só que eles não entenderam, entenderam que eu fui a pessoa errada, que eu fui o violento. Sim, errei, não era para eu ter ido lá e feito o que eu fiz com o moleque, mas para mim aquilo ali na hora era a coisa mais certa, não tinha mais o que fazer ali. Para mim foi péssimo, porque eu pensei que eles iam me ajudar, porque eles estavam ali para me ajudar, não para prejudicar, mas acabaram prejudicando. Até no dia da audiência eu perguntei para a diretora se ela iria falar alguma coisa de que eu estava certo e ela disse que

${ }^{55}$ Os Ciejas são equipamentos públicos municipais voltados para a educação de jovens adultos no ensino fundamental. Foram criados em 2003 a partir da reformulação do antigo supletivo, tendo em vista adequar o ensino fundamental às "necessidades de jovens e adultos." 
não poderia falar mais nada. $\mathrm{O}$ juiz não me ouviu, né? Ele entrou na sala, perguntou meu nome e tudo, perguntou porque eu fiz aquilo. Ele falou que eu estava errado, me julgou. Ele não deu nenhum minuto para eu falar, mandou eu assinar o papel e ficar na sala de espera. Na hora em que eu ia explicar por que tinha feito aquilo, ele falou: pode sair da sala! As 3 horas tinha acabado a audiência, quando eram 6 horas eu desci para a Fundação [Casa]. O advogado não falou nada na audiência, ele ficou calado, eu nem sabia quem era o advogado na audiência. Fiquei sabendo quando recebi minha LA [liberdade assistida] que era uma mulher. Para mim, eu não sabia quem era o promotor, quem era o advogado. Depois que eu recebi a LA é que eu fui saber, porque eu perguntei para a moça porque ela estava com uns papéis lá e ela falou assim: você ganhou sua LA. Aí eu olhei assim e perguntei: A senhora é o quê? Aí ela falou: - Eu sou sua advogada. (Entrevista concedida por Bruno para o CDHEP).

Em seu relato, Bruno chama a atenção por demonstrar certa continuidade entre a prática do abrigo, a da polícia e a do judiciário. Segundo a sua narrativa, ele foi pouco ouvido e a tônica dos procedimentos adotados foi a da punição - começando pela coordenadora do abrigo, que recorreu à polícia para a resolução de um conflito entre os jovens, prática que, embora condenada por diversas lideranças e profissionais que atuam na defesa dos direitos de crianças e adolescentes na região, é muito comum também em escolas.

A vida de Bruno é marcada pela presença de instituições e de profissionais do judiciário e das políticas sociais: abrigos, conselhos tutelares, advogados, psicólogos, serviços de medidas socioeducativas. E também pela reprodução da violência de Estado. É possível recuperar o trecho de sua fala em que ele espera a proteção do Estado: "Para mim foi péssimo, porque eu pensei que eles iam me ajudar, porque eles estavam ali para me ajudar, não para prejudicar, mas acabaram prejudicando". No entanto, o que recebe é a punição. Um tratamento que se repete nas instituições públicas, que tratam jovens majoritariamente negros e pobres como perigo em potencial.

No entanto, num determinado momento da conversa que tive com ele, Bruno fala sobre quando as coisas mudaram, isto é, quando ele foi para a MSE Capão II. Lá, foi atendido pela técnica Fernanda que, segundo a sua fala, "nem parecia psicóloga". Esta última expressão me chamou muito a atenção justamente pela percepção que ele tinha sobre as muitas "psicólogas" que teria encontrado em sua trajetória. Tais psicólogas são denominadas pela política de assistência social e de criança e adolescente, bem como pelo judiciário, de "técnicas", que estabelecem um determinado "vínculo padrão", como veremos no próximo capítulo. Mas com Fernanda a relação foi diferente - se a relação entre "técnico" e "atendido" não foi desconstruída, foi ao menos desestabilizada. 
O trabalho de Bruno no Cieja também é o de deslocar os lugares previstos. Assim, apesar de ter sido "atendido", Bruno também construiu sua trajetória e suas relações, que o levaram novamente para a rede de serviços, mas agora como profissional - embora como um cargo de auxiliar, pois não possui ensino superior e , assim, não se enquadra nos cargos té

Não é tão incomum que jovens "atendidos" em serviços públicos e projetos sociais tornem-se posteriormente profissionais dos mesmos. Quando isso ocorre, inclusive, é motivo de "orgulho" da instituição: como se demonstrasse um resultado do projeto ou da política em garantir o "desenvolvimento" da criança ou do jovem a ponto de conseguirem assumir um cargo entre "nós".

Nesse sentido, a política de assistência social são lugares fundamentais de observação para se entender os efeitos da presença do Estado na periferia. Primeiro, porque foi um dos principais veículos a partir dos quais o Estado se capilarizou por instituições e movimentos sociais, impondo sua forma de organização de poder por meio de convênios estabelecidos entre os movimentos e a prefeitura para a execução de políticas sociais. Segundo, porque são ações estatais que buscam normatização e o controle a partir da intervenção em trajetórias e comportamentos das famílias. Terceiro, porque oferecem uma rede de trabalho para moradores da periferia, contribuindo assim para a construção de trajetórias profissionais de assistentes sociais, educadores, psicólogos, etc. E, por fim, é uma das margens do Estado, que não deixa de apresentar resistências e tensões exercidas pelos sujeitos que nelas estão.

\section{As políticas sociais e a assistência social}

O debate sobre periferia e, no mesmo bojo, sobre vulnerabilidade, pobreza e exclusão esteve vinculado à problematização do lugar do Estado não só como causa desses problemas sociais, mas também como possibilidade de resolução e prevenção a partir de sua função de intervenção no sentido de promover direitos. Esse debate, bem como as lutas que sustentaram a abertura do regime e a formulação da Constituição de 1988 (demandas por igualdade e proteção), convergem para o reconhecimento de Estados de bem-estar, definidos como organizadores de sistemas de garantias legais que têm por objetivo realizar, fora da esfera privada, o acesso a bens e serviços que assegurem a proteção social do indivíduo em face de alguns riscos e vulnerabilidades sociais. Incluem-se aqui ações no sentido da proteção contra riscos sociais (doença, velhice, morte, desemprego), contra a pobreza (programas de mínimos sociais) e de garantia de acesso aos serviços de educação e saúde (Cardoso e Jaccoud, 2005). 
A questão da intervenção social em "prol dos pobres" teve início em ações e instituições de caráter assistencial não estatal, movidas por ideias de caridade e solidariedade ou, ainda, pela promessa da inclusão no mundo corporativo e dos direitos trabalhistas a ele vinculados durante o Milagre Econômico. Esses valores filantrópicos e de "melhoria de vida" pelo trabalho articulam-se com a consolidação do sistema brasileiro de proteção social, que é um "conjunto de políticas e programas governamentais destinados à prestação de bens e serviços e à transferência de renda, com o objetivo de cobertura de riscos sociais, garantia de direitos sociais, equalização de oportunidades e enfrentamento das condições de destituição e pobreza" (Cardoso e Jaccoud, 2005, p. 194). Tal consolidação ocorre somente após a Constituição de 1988 com a inclusão da noção de direitos, lançando assim as bases para uma expressiva alteração da intervenção social do Estado, alargando o arco dos direitos sociais e o campo da proteção social sob responsabilidade estatal, com impactos relevantes no que diz respeito ao desenho das políticas e à definição dos beneficiários (Cardoso e Jaccoud, 2005, p. 194).

Entre os avanços da Constituição de 1988 na determinação da responsabilidade estatal em função da necessidade de proteção social dos cidadãos, pode-se destacar: i) a instituição da Seguridade Social como sistema básico de proteção social, articulando e integrando as políticas de seguro social, assistência social e saúde; ii) o reconhecimento da obrigação do Estado em prestar, de forma universal, pública e gratuita, atendimento na área de saúde em todos os níveis de complexidade; para tanto, o texto constitucional prevê a instituição do Sistema Único de Saúde (SUS), sob gestão descentralizada e participativa; iii) o reconhecimento da assistência social como política pública, garantindo direito de acesso a serviços por parte de populações necessitadas, e direito a uma renda de solidariedade por parte de idosos e portadores de deficiência em situação de extrema pobreza; iv) o reconhecimento do direito à aposentadoria não integralmente contributiva (ou seja, parcialmente ancorada em uma transferência de solidariedade) dos trabalhadores rurais em regime de economia familiar; e v) o reconhecimento do seguro-desemprego como direito social do trabalhador a uma provisão temporária de renda em situação de perda circunstancial de emprego (Cardoso e Jaccoud, 2005, p. 182).

Pode-se observar a existência de quatro diferentes grupos de políticas sociais: i) políticas que se agrupam em torno do Eixo do Emprego e do Trabalho; ii) políticas que se agrupam em torno do Eixo da Assistência Social e do Combate à Pobreza; iii) políticas que se 
agrupam em torno do Eixo dos Direitos Incondicionais de Cidadania Social; e iv) políticas que se agrupam em torno do Eixo da Infraestrutura Social.

\section{Brasil: abrangência da ação social do Estado em âmbito federal ${ }^{56}$}

\begin{tabular}{|l|l|}
\hline \multicolumn{1}{|c|}{ Eixos estruturantes } & \multicolumn{1}{|c|}{ Principais politicas sociais, por área de atuação do GSF } \\
\hline Emprego e & 1. Previdência Social Básica (RGPS urbano e rural) \\
Trabalho & 2. Previdência e benefícios a servidores da União (militares e estatutários) \\
& 3. Políticas de apoio ao trabalhador \\
& 4. Organização agrária e política fundiária \\
Assistência Social e & 5. Assistência Social \\
Combate à Pobreza & 6. Alimentação e nutrição \\
& 7. Ações de Combate à Pobreza/transferência de renda \\
Direitos Incondicionais de & 8. Saúde \\
Cidadania Social & 9. Ensino Fundamental \\
Infra-Estrutura Social & 10. Habitação \\
& 11. Saneamento \\
\hline
\end{tabular}

No bojo da ampliação de vários direitos, outras determinações complementares foram surgindo, sobretudo na década de 1990 e no decênio de 2000, como a Lei Orgânica de Assistência Social (Loas, 1993), o Estatuto da Criança e Adolescente (ECA, 1996) e o Estatuto da Juventude (2012), só para citar alguns que estão mais relacionados a este trabalho.

No sistema brasileiro de proteção, de acordo com o artigo primeiro da Loas, está indicado:

A assistência social, direito do cidadão e dever do Estado, é a Política de Seguridade Social não contributiva, que provê os mínimos sociais, realizada através de um conjunto integrado de iniciativas pública e da sociedade, para garantir o atendimento às necessidades básicas. (Lei 8742, 1993, art.1)

Segundo a Norma Operacional Básica NOB/Suas da Política Nacional de Assistência Social PNAS/2004, afirma-se:

A Política Pública de Assistência Social realiza-se de forma integrada às

\footnotetext{
${ }^{\mathbf{5 6}}$ Fonte: Disoc/Ipea. Elaboração dos autores.

Notas: 1 Ano de Referência: 2002. Segue critério de organização do Gasto Social Federal (GSF), por área de atuação, segundo metodologia desenvolvida e utilizada na Disoc/Ipea. A respeito, ver Castro et alii (2004).

2 Diz respeito ao conjunto de políticas que definem, tradicionalmente, um sistema público de emprego.

3 Considera-se aqui o ensino fundamental como a única política de educação plenamente inserida no Eixo dos Direitos Incondicionais de Cidadania Social. Com relação ao ensino médio, superior e profissional, nos quais se concentra a maior parte dos gastos federais em educação, a rigor, estes não atendem aos critérios usados para classificar as políticas neste Eixo da Cidadania Social (pea , , p. 197).
} 
políticas setoriais, considerando as desigualdades socioterritoriais, visando ao seu enfrentamento, à garantia dos mínimos sociais, ao provimento de condições para atender contingências sociais e à universalização dos direitos sociais. Sob essa perspectiva, objetiva: prover serviços, programas, projetos e benefícios de proteção social básica e/ou especial para famílias, indivíduos e grupos que deles necessitarem; contribuir com a inclusão e a equidade dos usuários e grupos específicos, ampliando o acesso aos bens e serviços socioassistenciais básicos e especiais, em áreas urbana e rural; assegurar que as ações no âmbito da assistência social tenham centralidade na família, e que garantam a convivência familiar e comunitária. (PNAS, 2004, p. 33)

Os serviços de assistência social no Brasil estão organizados a partir do Sistema Único de Assistência Social (Suas), que articula esforços e recursos dos três níveis de governo, isto é, municípios, estados e União, para a execução e o financiamento da Política Nacional de Assistência Social (PNAS), envolvendo diretamente estruturas e marcos regulatórios nacionais, estaduais, municipais e do Distrito Federal ${ }^{57}$.

O sistema é coordenado pelo governo federal via Ministério do Desenvolvimento Social, enquanto a grande maioria dos serviços é executada pela gestão municipal - no caso de São Paulo, pela Secretaria Municipal de Assistência e Desenvolvimento Social (Smads). Seguindo então a hierarquia, ligadas à Smads existem as 31 Supervisões de Assistência Social (SAS), uma por subprefeitura, as quais gerem os serviços que estão na "ponta" do sistema, ou seja, os que atendem diretamente a população.

${ }^{57} \mathrm{Cf}$. http://mds.gov.br/assuntos/assistencia-social/o-que-e 


\section{Secretaria Municipal de Assistência e Desenvolvimento Social - Estrutura ${ }^{58}$}

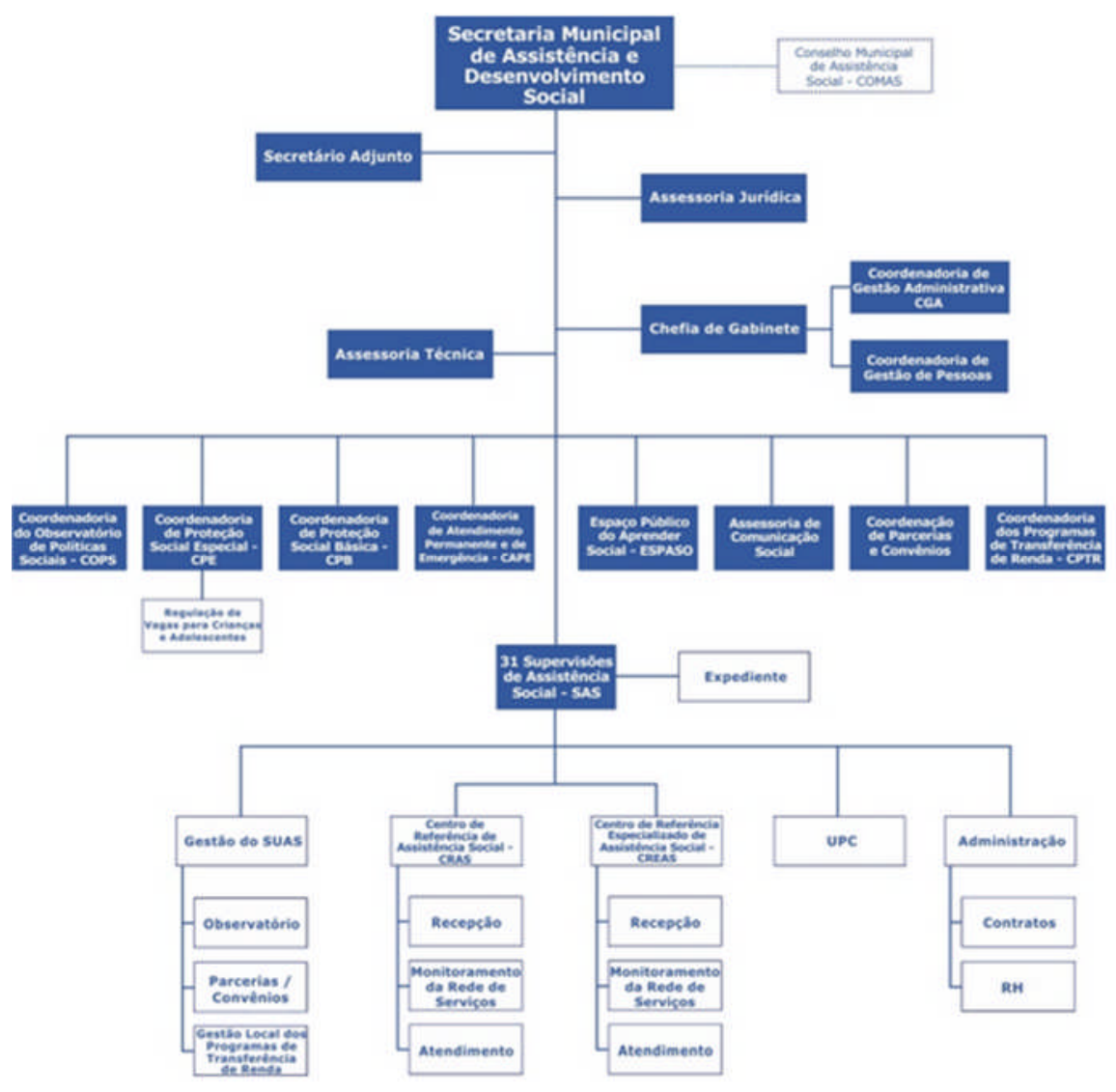

Nesta estrutura burocrática, o Cras e o Creas concentram o atendimento direto à população, isto é, formam a "ponta" da política. Cada um destina-se a um tipo de proteção, conforme a divisão do sistema: a básica e a especial.

De acordo com o PNAS, os serviços de proteção social básica tem como objetivo prevenir situações de risco por meio do desenvolvimento de potencialidades e aquisições e do fortalecimento de vínculos familiares e comunitários. Destina-se à população que vive em situação de vulnerabilidade social decorrente de pobreza, privação e/ou fragilização de vínculos afetivos-relacionais e de pertencimento social (discriminações etárias, étnicas, de gênero ou por deficiências, dentre outras). Já a proteção social especial é uma modalidade de atendimento assistencial destinada a famílias e indivíduos que se encontram em situação de

\footnotetext{
${ }^{58}$ Secretaria Municipal de Assistência e Desenvolvimento Social. Cf. http://www.prefeitura.sp.gov.br/cidade/secretarias/assistencia_social/secretaria/estrutura/index.php?p=1781
} 
risco pessoal e social por ocorrência de abandono, maus tratos físicos e/ou psíquicos, abuso sexual, uso de substâncias psicoativas, cumprimento de medidas socioeducativas, situação de rua, situação de trabalho infantil, entre outras.

Tanto o Cras quanto o Creas são equipamentos estatais cujos funcionários são servidores públicos. Eles são lugares de atendimento, encaminhamento e supervisão de outros serviços. O Cras é a principal "porta de entrada dos usuários à rede de proteção social do Suas”. Ele também coordenada a rede de serviços socioassistenciais locais da política de assistência social: CCAs (Centro de Crianças e Adolescentes, entre 6 e 13 anos e 11 meses) e CJs (Centros de Juventude, entre 14 e 17 anos e 11 meses), serviços que "visam promover o fortalecimento de vínculos sociais e familiares por meio de atividades de convivência ${ }^{59}$; bem como o SASF (Serviço de Assistência à Família), tendo em vista desenvolver proteção social básica no domicílio junto a famílias em situação de risco e de vulnerabilidade social, idosos e pessoas com deficiência, buscando a convivência e o fortalecimento de vínculos familiares e comunitários por meio de ações socioeducativas.

Já o Creas é o equipamento responsável pelo atendimento de proteção especial e ele coordena os Saicas (que acolhe crianças e adolescentes até 17 anos "cujas famílias ou responsáveis encontram-se temporariamente impossibilitados de cumprir sua função de cuidado e proteção, respeitando os princípios legais de brevidade e excepcionalidade"60); os MSEs (Medida Socioeducativa em Meio Aberto), que tem por fim prover atenção socioassistencial a adolescentes que estão em liberdade assistida determinada judicialmente, devendo contribuir para o acesso a direitos e ressignificação de valores na vida pessoal e social; o NPJ (Núcleo de Proteção Jurídico Social e Apoio Psicológico), que tem por finalidade orientar e acompanhar famílias com um ou mais de seus membros em situação de ameaça ou violação de direitos, compreendendo ações para promoção de direitos, preservação e fortalecimento de vínculos familiares, comunitários e sociais, fortalecendo, assim, a função protetiva das famílias diante de um conjunto de condições que as vulnerabilizam.

Dessa forma, a estrutura da política presente no território é a seguinte:

\footnotetext{
${ }^{59}$ Tecendo Redes de Cuidado: Fortalecimento do Sistema de Garantia de Direitos da Criança e do Adolescente e Práticas de Justiça Restaurativa

${ }^{60}$ Ibdem
} 


\section{Supervisão de Assistência Social por Subprefeitura - Estrutura}

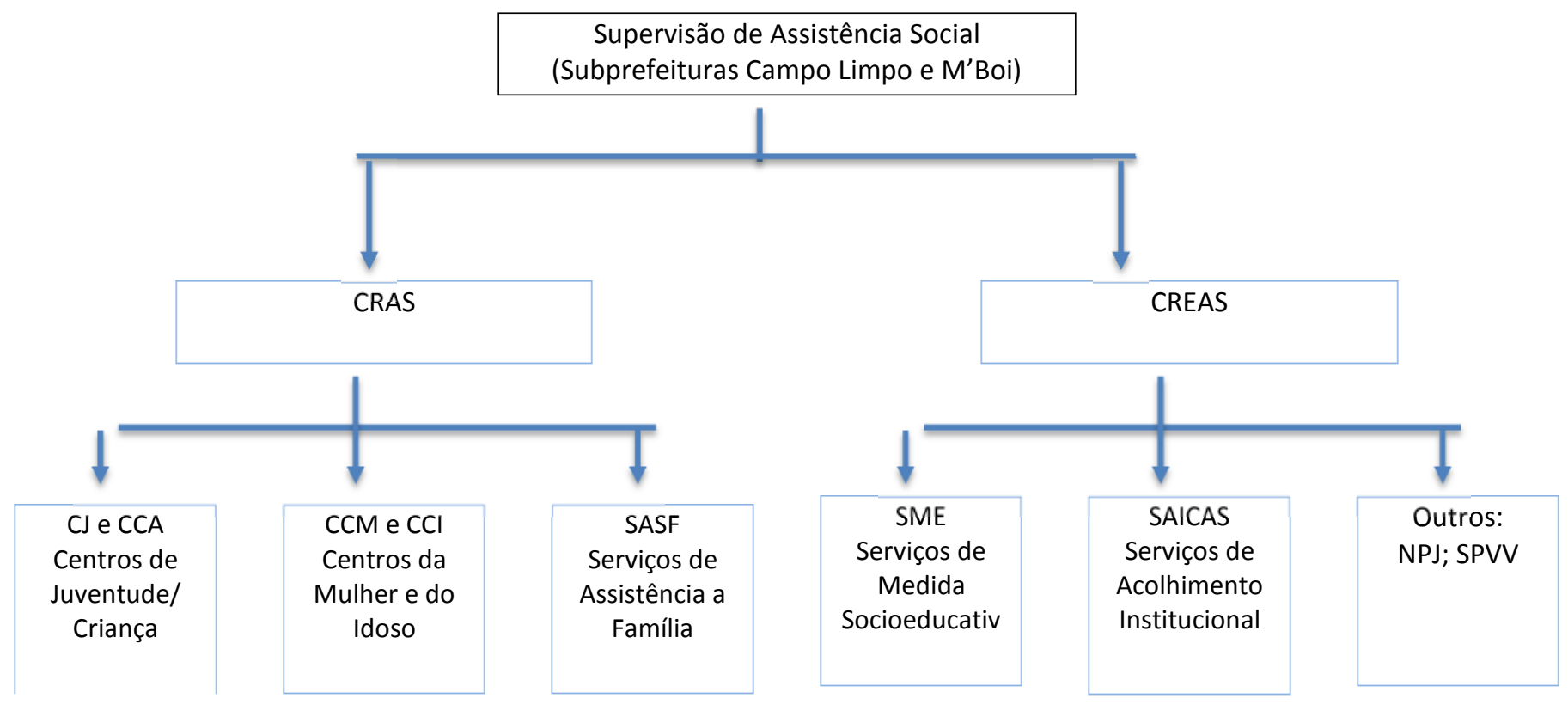

O fluxo de atendimento padrão é então pela "porta de entrada" do Cras, que encaminha para a rede socioassistencial, no caso de proteção básica, de acordo com a demanda; ou do Creas, que também encaminhará para os serviços específicos. Vale ressaltar que a maioria das demandas para o Creas vem de encaminhamentos de outros serviços tanto da assistência social quanto do judiciário, que encaminham vítimas de violência, crianças em situação de "abrigamento" ou jovens em "conflito com a lei" para atendimento específico. Observar a prática cotidiana desses serviços revela a grande proximidade entre judiciário, assistência social e órgãos repressivos como a polícia militar, a Fundação Casa e os presídios, como indicam os relatos descritos acima, compondo de fato uma rede, mas que atua muito mais numa perspectiva punitiva (e burocrática) do que na dinâmica dos direitos preconizada nos inúmeros documentos normativos, como pretendo desenvolver mais a frente.

Com exceção do Cras e do Creas, todos os outros serviços a eles "referenciados" são executados por instituições da sociedade civil, isto é, aquelas que desenvolvem atividades diretamente com o "público alvo". Muitas são oriundas de movimentos sociais históricos da região, outras surgiram mais recentemente a partir da possibilidade de execução de serviços, em parte ligadas a segmentos religiosos, sobretudo o católico e o evangélico. Os funcionários são contratados pela instituição executora, não passando pelo crivo da Secretaria de Assistência Social. As condições de trabalho desses serviços, se comparadas às dos funcionários públicos do Cras e do Creas, são mais precárias, sem estabilidade e com baixos 
salários, o que gera grande rotatividade de profissionais.

No entanto, observa-se uma quantidade muito maior de moradores na região trabalhando nesses serviços executados por instituições da sociedade civil, do que nos Cras ou Creas, justamente por prescindir de concurso público, exigidas pela contratação direta do Estado. Nos serviços executados indiretamente existe também uma maior "autonomia" de trabalho, como afirmam os próprios funcionários.

Aqui é oportuno retomar o argumento de Gabriel Feltran sobre como muitos dos movimentos sociais da década de 1980 da periferia foram incorporados de uma maneira marginal na política, executando serviços das políticas sociais a partir dos anos 1990 (Feltran, 2010). O que defendo aqui é que, a partir da execução dessas políticas e de convênios com o poder público, a lógica de organização estatal se impõe na periferia segmentando a população em "públicos-alvo", absorvendo sujeitos em sua estrutura e redefinindo relações em instituições que antes faziam parte da luta. Assim, não se trata mais de "companheiros de luta" e de "relações de solidariedade". Agora, a relação seria intermediada por relatórios, documentos normativos, protocolos de atendimentos entre "públicos-alvo" e instituições em que os sujeitos se encontram em relações hierárquicas de poder.

Segundo Andrea Arruda, moradora da região há quase de 40 anos com uma longa e consolidada trajetória de ativismo e trabalho nas políticas sociais e em ONGs da região:

\footnotetext{
A maioria das organizações aqui da região, Bom Jesus, Associação do Vila Remo, Santos Mártires, Jardim Comercial, surgiram de movimentos sociais. Panela vazia, movimento de mães, luta por creche, muita questão de moradia. E muitas dessas organizações começam a estabelecer relações com os moradores não mais de militância, mas de trabalho, muitas vezes de exploração, de relações trabalhistas. Não tendo diferenças de uma empresa, você acaba sendo um colaborador do sistema. (Andrea Arruda, ativista)
}

Essa afirmação, carregada de frustração por ter vivido também diversos episódios de conflitos com algumas instituições, recoloca o argumento de Gabriel Feltran a fim de observar os efeitos dessa inserção marginal na política nas relações cotidianas na periferia. Isto é, as consequências foram não só o esvaziamento político das ações de movimentos que ficaram submetidos ao Estado, mas também a redefinição das relações destas instituições com a população local. Não são mais relações horizontais, de "luta" e solidariedade, mas sim de trabalho, muitas vezes precário. Tal precariedade é derivada não só dos reduzidos recursos repassados, mas também da dificuldade de gestão financeira e burocrática de muitas dessas instituições, boa parte delas endividada, principalmente - mas não apenas - por direitos 
trabalhistas.

A execução dessas políticas prevê um planejamento de execução que exige alto domínio burocrático, sobretudo em relação aos programas do governo federal, todos geridos via $\mathrm{SICONV}^{61}$. Esse sistema é altamente burocratizado e muito pouco flexível no que se refere a alterações e mudanças nos termos inicialmente previstos dos projetos. Sendo assim, muitas instituições que estavam acostumadas a gerir recursos de forma muito mais espontânea, como por meio de fundos criados a partir de festas comunitárias, rifas e formações locais, são obrigadas a se habituar com a complexidade e rigidez da burocracia estatal. Resultado: ou as instituições se burocratizavam ou não teriam acesso aos recursos disponíveis.

Outro tipo de relação que surge com a execução dessas políticas sociais é a que ocorre no interior dos serviços a partir da emergência de duas novas categorias: o "usuário" ou "atendido" ou "beneficiário" da política; e o "técnico do serviço", nomenclatura forjada na relação entre Estado e população no oferecimento das políticas sociais. Aqui não se perde a noção da cidadania como possibilidade de participação política, mas se fortalece a ideia de cidadão enquanto "usuário" do Estado. E essa relação está repleta de representações, hierarquias, estigmas. Na hierarquia estabelecida pela implementação de tais políticas, consolida-se uma estrutura piramidal de poder a partir da qual são estabelecidas relações desiguais: diretoria/conselhos/coordenações das instituições e as supervisões das secretarias; trabalhadores, técnicos, colaboradores dos serviços; e, por fim, os usuários, beneficiários. Estabelecem-se relações de trabalho entre instituições e profissionais; relações de controle, muitas vezes encobertas por discursos de cuidado e proteção. Participei de inúmeras reuniões de profissionais dessas políticas, que tratam desde questões técnicas até disputas políticas em torno da assistência social e seus serviços, bem como encaminhamentos de caso e raramente presenciei a participação de algum "usuário" - com exceção de pequenas iniciativas que estão começando a ser forjadas em alguns serviços com o apoio de coletivos locais, as quais tratarei no próximo capítulo.

Poderíamos talvez afirmar que os movimentos sociais que foram incorporados à hierarquia do Estado perderam, assim, a força política. Enfrentar o Estado pode significar um real risco à possibilidade de manutenção do convênio. Ou, ainda, o recurso destinado à execução das políticas é tão reduzido que a equipe institucional acaba sendo totalmente

\footnotetext{
${ }^{61}$ O SICONV (Sistema de Gestão de Convênios e Contratos de Repasse) é uma ferramenta eletrônica que reúne e processa informações sobre as transferências de recursos do governo federal para órgãos públicos e privados sem fins lucrativos. Esse repasse acontece por meio de contratos, convênios e termos de parceria destinados à execução de programas, projetos e ações de interesse comum.
} 
absorvida pelas demandas burocráticas. Por fim, devido a especificidade dos serviços, o "perfil" profissional que vai sendo agregado à instituição é o de "técnico" e não o de "ativista", como observado por Gabriel Feltran em seu trabalho sobre o Cedeca ${ }^{62}$ Sapopemba, em que ele acompanha todo esse processo de "tecnização" da instituição e os conflitos gerados internamente a partir desse esvaziamento político (Feltran, 2008).

Durante minha trajetória profissional e de ativismo, a maioria dos profissionais que encontrei tinha de fato um posicionamento que pouco problematizava as políticas e suas burocracias. No entanto, conheci alguns que buscavam tencionar os discursos e as práticas naturalizadas das políticas, como é o caso dos funcionário do MSE Capão II, de que tratarei no próximo capítulo. Como eles, encontrei profissionais que, diferente das instituições, que não assumiam uma atuação política nas articulações locais como responsabilidade institucional, incumbiam-se dessa participação política individualmente.

Retomo, aqui, o argumento de que o Estado se impõe como uma forma de organização do poder que se ordena de maneira hierárquica, classificando, segmentando. Assim, as políticas sociais que se expandiram nos últimos 30 anos, sobretudo as de assistência social, além de sustentar práticas e discursos normativos e de controle, tiveram efeitos "secundários", contribuindo para a ampliação e a burocratização do campo da "gestão social" na periferia e, assim, foram capazes de influenciar nas trajetórias de seus moradores. Entendo tal gestão como as margens do Estado na periferia, intermediando as relações entre "população" e políticas. No entanto, essa intermediação se dá em bases hierárquicas entre "técnicos" e "público-alvo", reforçando processos de estigmatização.

Neste capítulo, tentei levantar elementos desse processo. No próximo, busco me aprofundar um pouco mais nessa dinâmica cotidiana a partir do Serviço de Medida Socioeducativa Capão II, em que ressalto resistências frente a essa imposição do Estado.

\footnotetext{
62 "Os Cedecas são organizações da sociedade civil, sem fins lucrativos, com autonomia formal de gestão, mas com a função de articular as dimensões social e jurídica da proteção dos direitos de crianças e adolescentes. São, portanto, entidades que têm como função executar a mediação entre os direitos formais e sua garantia no tecido social" (Feltran, 2008, p. 209, grifos no original).
} 


\section{Capítulo 4 - Os Serviços de Medidas Socioeducativas em Meio}

\section{Aberto}

\section{A política}

Dos profissionais de assistência social, os que mais encontro nas reuniões de articulação e nas atividades de coletivos da região são os "técnicos" de medida socioeducativa. São pessoas com quem, inclusive, estabeleci relações muito próximas de trabalho e militância. Em sua maioria, são jovens moradores da região, quase todos com formação nas áreas de psicologia, pedagogia, história, assistência social e ciências sociais. Muitos deles também são ativistas de algum coletivo e, não raro, têm uma carreira profissional já consolidada no campo de "gestão social" a partir da experiência de trabalho em outros serviços da assistência, ONGs e educação.

Minha intenção neste capítulo é a de apresentar os documentos que orientam a medida socioeducativa, problematizando seus pressupostos, que tendem a individualizar as causas da “exclusão social” e da infração cometidas por adolescentes, gerando, assim, projetos normatizadores voltados para jovens pobres e suas famílias. Busquei também demonstrar como tais documentos estão distantes da "realidade" desses serviços, de sua execução cotidiana, ou seja, de suas "pontas". E, finalmente, procurei entender como os sujeitos neles envolvidos são influenciados por discursos e práticas que circulam horizontalmente pelo território a fim de resistir à imposição dessas políticas, criando espaços de "luta" e resistência.

Os Serviços de Medida Socioeducativa de Liberdade Assistida e Prestação de Serviços à Comunidade (MSE) são responsáveis por executar medidas socioeducativas para jovens que estão cumprindo liberdade assistida (LA) ou prestação de serviços à comunidade (PSC). Essas medidas, previstas no Estatuto da Criança e do Adolescente (ECA), são aplicadas a crianças e jovens que cometeram ato infracional, isto é, conduta descrita como crime ou contravenção penal (art. 103 do ECA). Outras medidas incluem: advertência, obrigação de reparar o dano, inserção de regime em semiliberdade, internação em estabelecimento educacional (art. 112 do ECA), uma vez que menores de 18 anos são penalmente inimputáveis (art.104 do ECA). Dentre essas medidas, apenas a de liberdade assistida e de prestação de serviços à comunidade são executadas pela secretaria de assistência social.

Aqui talvez seja oportuno deter-se um pouco mais no ECA, sendo ele um instrumento normativo muito mobilizado no cotidiano, tanto em discursos de ativistas quanto nas práticas 
do Estado. Todos conhecem o ECA: técnicos das políticas sociais, professores, jovens e suas famílias, ativistas. Talvez esta seja a lei mais presente nos discursos na periferia, juntamente com a Lei Maria da Penha ${ }^{63}\left(n^{\circ} 11.340,2006\right)$. Mas isso não significa que esteja de fato internalizada nas práticas e nas relações entre adultos, crianças e adolescentes. Ao contrário, é instrumento de disputa e alvo de críticas por "tirar a autonomia das famílias em educar seus filhos" ou mesmo "proteger em demasia infratores". Publicações desse estatuto são frequentemente distribuídas em escolas e serviços públicos que trabalham com crianças e adolescentes. Constantemente, também se oferecem as polêmicas "formações sobre o ECA". Digo polêmicas, pois muitas vezes são consideradas enfadonhas e "pouco atrativas". Mas, enfim, o que pretendo dizer aqui é que o ECA é popular na "quebrada" 64 - não profundamente conhecido, mas popular.

O Estatuto da criança e do adolescente é considerado o principal avanço normativo no campo das crianças e adolescentes. Lei Federal n 8.069, aprovada em 13 de julho de 1990, o ECA substitui o Código do Menor, que se baseava no paradigma da "situação irregular" que designava os “desviantes": crianças e adolescentes vítimas de violência doméstica e maus tratos, situação de pobreza, órfãos, situação de rua, vítimas de exploração sexual ou autores de atos infracionais que deveriam ser tutelados pelo Estado.

O surgimento do ECA significou então uma ruptura normativa com tal paradigma estabelecendo um outro, a da "proteção integral":

\begin{abstract}
Muda-se com isso o quadro de montagem institucional e normativa da questão: aquelas crianças e adolescentes, ao invés de figuradas como "desviantes", passariam a ser compreendidas como sujeitos cujos direitos estão ameaçados ou violados, e que, portanto, devem ser restituídos. A ação estatal se deslocaria, em teoria, da repressão para a proteção especial. Não haveria mais uma sociedade da qual eles estariam excluídos, mas uma comunidade política formal de cidadãos, integrada de todo modo por eles, e que assim teria a responsabilidade de zelar pela garantia de seus direitos. As políticas públicas seriam formas de concretizar esta garantia, e por isso deveriam ser intersetoriais: cria-se neste momento todo um sistema de participação social nestas políticas, voltado para garantir a presença capilar de diversos atores do que se convencionou chamar "rede de proteção" dos direitos de crianças e adolescentes. (Feltran, 2008, p. 206, grifos no original)
\end{abstract}

Constituiu-se, assim, o Sistema de Garantia de Direitos da Criança e do Adolescente,

\footnotetext{
${ }^{63}$ Dispositivo legal que visa aumentar o rigor das punições sobre crimes domésticos. É normalmente aplicada aos homens que agridem fisicamente ou psicologicamente a uma mulher ou à esposa, o que é mais recorrente.

${ }^{64}$ Termo utilizado por grande parte dos moradores da periferia para se referir a bairros ou lugares íntimos ou familiares na periferia. "Chega mais tarde lá na minha quebrada”, para se referir à própria rua, casa ou bairro.
} 
composto por: segmentos do Judiciário - Varas da Infância e Juventude -; rede das políticas sociais; e participação da sociedade civil - a partir de conselhos municipais, estaduais e nacionais, bem como de conselhos tutelares. Assim, família, sociedade e Estado estariam agindo em rede para garantir os direitos de crianças e adolescentes, os quais passaram a ser vistos como pessoas em situação peculiar, tendo em vista seu desenvolvimento. No campo das políticas sociais, amplia-se então todo um conjunto de serviços, visando "proteger crianças e adolescentes da violência e educar os infratores": Centros de Crianças e Adolescentes (CCA), Centros de Juventude (CJ), Serviço de Acolhimento Institucional para Crianças e Adolescentes (Saicas), Serviços de Medida Socioeducativa em Meio Aberto (MSEs), SPVV (Serviço de proteção a Vítimas de Violência), dentre outros.

Os Serviços de Medida Socioeducativa compõem então essa rede, sendo a "ponta" do atendimento de jovens em liberdade assistida. E o fluxo de atendimento parte do Judiciário, por meio das Varas da Infância e Juventude, encaminhando os "autores de ato infracional" para o Creas que, por sua vez, encaminha para os serviços de medida socioeducativa onde os adolescentes terão atendimento. Os parâmetros das medidas socioeducativas são definidos principalmente por dois documentos normativos: a resolução 113 do Conselho Nacional dos Direitos da Criança e do Adolescente (Conanda), que determina o Sistema de Direitos da Criança e do Adolescente ${ }^{65}$, e pelo Sistema Nacional de Atendimento Socioeducativo $(\text { Sinase })^{66}$.

\footnotetext{
${ }^{65}$ O Sistema de Garantia de Direitos da Criança e do Adolescente constitui-se na articulação e integração das instâncias públicas governamentais e da sociedade civil na aplicação de instrumentos normativos e no funcionamento dos mecanismos de promoção, defesa e controle para a efetivação dos direitos da criança e do adolescente, nos níveis federal, estadual, distrital e municipal. Compreendem este Sistema, prioritariamente, os seguintes eixos: Defesa dos Direitos Humanos: os órgãos públicos judiciais; o ministério público, especialmente as promotorias de justiça, as procuradorias gerais de justiça; defensorias públicas; advocacia geral da união e as procuradorias gerais dos estados; polícias; conselhos tutelares; ouvidorias e entidades de defesa de direitos humanos incumbidas de prestar proteção jurídico-social. Promoção dos Direitos: A política de atendimento dos direitos humanos de crianças e adolescentes operacionaliza-se por meio de três tipos de programas, serviços e ações públicas: 1) serviços e programas das políticas públicas, especialmente das políticas sociais, afetos aos fins da política de atendimento dos direitos humanos de crianças e adolescentes; 2) serviços e programas de execução de medidas de proteção de direitos humanos e; 3) serviços e programas de execução de medidas socioeducativas e assemelhadas. Controle e Efetivação dos Direitos: realizado por meio de instâncias públicas colegiadas próprias, tais como: conselhos dos direitos de crianças e adolescentes; conselhos setoriais de formulação e controle de políticas públicas; e os órgãos e os poderes de controle interno e externo definidos na Constituição Federal. Além disso, de forma geral, o controle social é exercido soberanamente pela sociedade civil, por meio das suas organizações e articulações representativas. Cf. http://www.sdh.gov.br/assuntos/criancas-e-adolescentes/programas/fortalecimento-de-conselhos/garantia-dedireitos-da-crianca-e-do-adolescente

${ }^{66}$ O Sinase é o conjunto ordenado de princípios, regras e critérios de caráter jurídico, político, pedagógico, financeiro e administrativo, que envolve desde o processo de apuração de ato infracional até a execução de medida socioeducativa. Esse sistema nacional inclui os sistemas estaduais, distrital e municipais, bem como todos as políticas, planos e programas específicos de atenção a esse público. Sistema Nacional De Atendimento Socioeducativo -Sinase/ Secretaria Especial dos Direitos Humanos - Brasília, DF: Conanda, 2006.
} 
Voltando às medidas, a PSC, prestação de serviços à comunidade, consiste na realização de tarefas gratuitas de "interesse geral" por período que não exceda seis meses. Segundo as normativas da política, tais tarefas devem ser atribuídas conforme as aptidões dos adolescentes e cumpridas em jornada máxima de oito horas semanais aos sábados, domingos e feriados, ou em dias úteis, de modo a não prejudicar a frequência à escola ou à jornada de trabalho.

Já a medida de LA, liberdade assistida, ocorre da seguinte forma:

Tem como objetivo estabelecer um processo de acompanhamento, auxílio e orientação ao adolescente. Sua intervenção e ação socioeducativa deve estar estruturada com ênfase na vida social do adolescente (família, escola, trabalho, profissionalização e comunidade) possibilitando, assim, o estabelecimento de relações positivas, base de sustentação do processo de inclusão social a qual se objetiva. Desta forma, o programa deve ser o catalisador da integração e inclusão social desse adolescente e sua família.(Sinase, 2006, p. 44)

O ECA estabelece o prazo mínimo de seis meses, podendo ser prorrogada, revogada ou substituída por outra medida em qualquer tempo, ouvindo o orientador designado pela autoridade judiciária competente, o coordenador ou os técnicos do programa de execução das medidas, o Ministério Público e o defensor público (§ 2o do artigo 118 ECA).

O Sinase prescreve minuciosamente parâmetros para o atendimento socioeducativo tendo em vista o "respeito aos interesses do adolescente", o "diálogo" e, sobretudo, o "acompanhamento" contínuo da medida realizado pelos técnicos. Além disso, as instituições executoras da medida realizam as atividades com os adolescentes tendo em vista um conjunto de diretrizes: prevalência da ação socioeducativa sobre os aspectos meramente sancionatórios; projeto pedagógico como ordenador de ação e gestão do atendimento socioeducativo; participação dos adolescentes na construção, no monitoramento e na avaliação das ações socioeducativas; respeito à singularidade do adolescente, presença educativa e exemplaridade como condições necessárias na ação socioeducativa; exigência e compreensão, enquanto elementos primordiais de reconhecimento e respeito ao adolescente durante o atendimento socioeducativo; diretividade no processo socioeducativo (autoridade e não autoritarismo); dinâmica institucional garantindo a horizontalidade na socialização das informações e dos saberes em equipe multiprofissional; organização espacial e funcional das unidades de atendimento socioeducativo que garantam possibilidades de desenvolvimento pessoal e social para o adolescente; diversidade étnico-racial, de gênero e de orientação sexual norteadora da 
prática pedagógica; família e comunidade participando ativamente da experiência socioeducativa; formação continuada dos atores sociais (Sinase, 2006, p. 47).

O Sinase ainda orienta acerca da equipe mínima necessária, do espaço satisfatório para realização de atividades e da necessidade de articulações com conselhos e redes locais a fim de potencializar a eficácia da medida.

Há muito a percorrer nos documentos normativos relacionados aos direitos da criança e do adolescente, mais especificamente no que se refere à questão do adolescente que cometeu "ato infracional", pois deparamo-nos com uma infinidade de leis, publicações, órgãos, em que um conduz ao outro: ECA, Sinase, PNAS etc. Todos propõem um conjunto de serviços, diretrizes e planos muito bem articulados no sentido de "proteger" este "sujeitos de direitos", tendo em vista sua condição peculiar de desenvolvimento.

No entanto, todos esses documentos - por mais progressistas que sejam em suas diretrizes no sentido de garantir um processo educativo e não meramente punitivo, preservando a singularidade e a participação do adolescente nesse processo - não questionam a "infração" e seu contexto. Isto é, o adolescente é julgado e "encaminhado" para a medida que, por sua vez, tem como pressuposto que o autor de um ato infracional de fato necessita de um processo educativo para que não volte a "errar". E tal "erro" estaria relacionado à sua inserção social "precária" e ao pouco apoio familiar, já que as atividades da medida são propostas no sentido de suprir tais precariedades e ausências. Somos levados então a supor que esses documentos reforçam a ideia de que adolescentes em situação de vulnerabilidade social estariam mais propensos a cometer atos infracionais - ideia esta presente em diversas atividades voltadas a crianças e adolescentes pobres que visam desenvolver atividades socioeducativas. Também individualizam a responsabilidade da precariedade da "inserção social", sem questionar a construção dos enquadramentos produzidos pelo próprio Estado sobre o que é infração ou crime.

Trata-se assim de uma medida que dá continuidade ao processo de enquadramento punitivo e normativo desses sujeitos como "infratores", o qual se inicia nos órgãos repressores do Estado que, nas margens, atuam a partir da polícia e da delegacia, seguindo para instâncias do judiciário e retornando para a "ponta" como medida socioeducativa.

Até no dia da audiência eu perguntei para a diretora se ela iria falar alguma coisa de que eu estava certo e ela disse que não poderia falar mais nada. $\mathrm{O}$ juiz não me ouviu, né? Ele entrou na sala, perguntou meu nome e tudo, perguntou porque eu fiz aquilo. Ele falou que eu estava errado, me julgou. Ele não deu nenhum minuto para eu falar, mandou eu assinar o papel e ficar 
na sala de espera. Na hora em que eu ia explicar o porque tinha feito aquilo ele falou: pode sair da sala! Às 3 horas tinha acabado a audiência, quando eram 6 horas eu desci para a Fundação [Casa]. O advogado não falou nada na audiência, ele ficou calado, eu nem sabia quem era o advogado na audiência. Fiquei sabendo quando recebi minha LA. (Bruno)

Repetindo o trecho do depoimento de Bruno do capítulo anterior, observa-se um processo que sobrepõe silenciamentos, punição e normatização. A medida socioeducativa torna-se portanto o fim - ou não, caso seja descumprida, o adolescente pode ser levado à internação - da institucionalização destes jovens.

Além disso, o Sinase propõe um processo ideal de desenvolvimento da medida socioeducativa desconsiderando as condições das políticas sociais disponíveis nas regiões em que é executada, sobretudo nas regiões da periferia da cidade. Vejamos o que diz uma técnica:

Quando o menino entra na medida socioeducativa, parece que ele entra num mundo paralelo. Agora vocês vão ter todos os direitos garantidos, vão acessar a escola, cursos, porque tem o PIA ${ }^{67}$, né? Curso, trabalho, escola, saúde, documentação. Tudo isso está lá no Sinase. Temos que garantir os direitos desses meninos. Mas ele volta para a mesma sociedade em que ele estava só que agora com o carimbo de LA. Agora, além de preto, pobre e favelado, ele é preto, pobre, favelado e bandido. É uma hipocrisia no relatório. Como se o menino em medida viesse para um mundo perfeito. (Sulamita)

Sulamita Assunção é "técnica" do serviço de medida socioeducativa do MSE Capão II. Sua fala ironizando o Sinase é bem comum entre as pessoas que vivenciam a "ponta" ao se referir aos documentos normativos. A experiência da precarização do serviço, de falta de apoio institucional, do estigma que recai sobre os adolescentes atendidos e as consequências desse estigma para a esperada "inserção social", o mundo do crime e da violência policial são realidades muito amargas. Realidades estas derivadas de processos sociais bem distintos e distantes das soluções propostas por esses documentos normativos. Estes, como mencionado anteriormente, pressupõem uma exclusão social individualizada do adolescente e de sua família - isto é, as atividades de apoio para estes sujeitos seriam a solução para o problema, pois facilitariam o caminho para a inserção social, não alcançada anteriormente pela incapacidade das famílias em acessarem as oportunidades disponíveis no território. Assim, uma vez o jovem inserido socialmente e consciente de seu erro, não haveria reincidência da

\footnotetext{
${ }^{67}$ Plano de Atendimento Individual previsto no Sinase. Nele é registrado todo o processo da medida e as avaliações de seus técnicos. A partir desses relatórios, os "casos" são encaminhados dos MSEs para o judiciário.
} 
infração.

Sentimento de impotência e medo, enfrentamento com a polícia, limites institucionais são as reclamações que ouço desses técnicos ao longo de minha trajetória nesse campo. Sobretudo daqueles que possuem uma perspectiva mais crítica, pois de fato existe um grande quantidade de profissionais que assumem uma postura ainda mais punitiva do que aquela prevista nos documentos normativos.

Sulamita, é o oposto deste estereótipo de "técnico burocrático" presente no discurso de profissionais mais engajados. Muito entusiasta e atuante, busca respostas e caminhos para aproximar o serviço da "realidade dos jovens". E mesmo considerando o Sinase "distante desta realidade", ela o utiliza como instrumento de luta. Foi nessas conversas com Sulamita que me aproximei do MSE Capão II e o restante da equipe.

\section{O MSE Capão II}

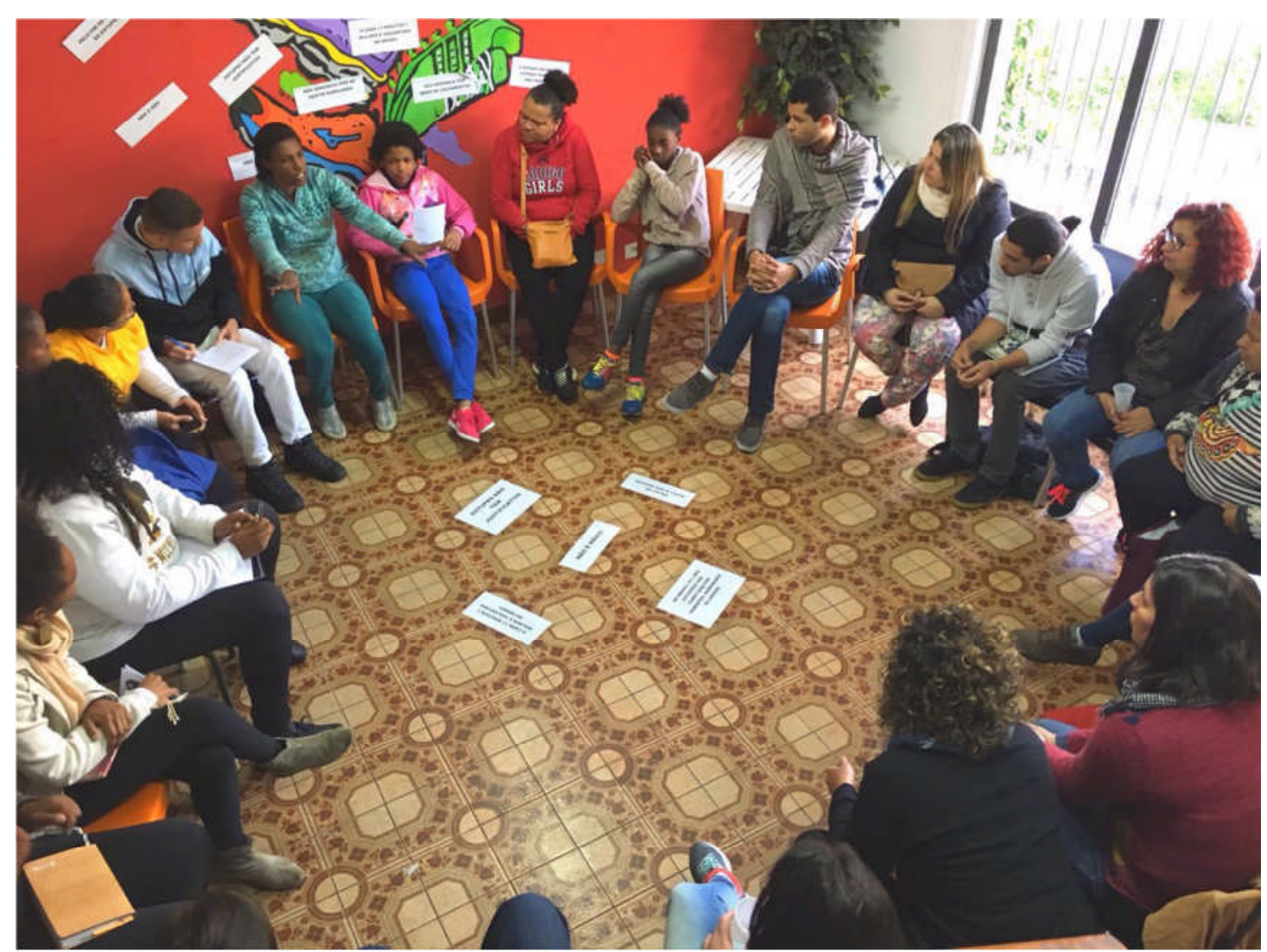

Reunião técnicos do MSE Capão II, famílias atendidas e Comitê Juventude e Resistência

O MSE Capão II está ligado ao Creas da subprefeitura do Campo Limpo e é coordenado pela Associação dos Moradores do Jardim Comercial e Adjacências, com sede no bairro de mesmo nome situado no distrito do Capão Redondo. Como mencionado em capítulos 
anteriores, esta instituição surgiu dos movimentos sociais por moradia que atuavam na região a partir da década de 1970 e, hoje, tem seus esforços voltados para os serviços das políticas de assistência social por meio de convênios com a prefeitura. Além do MSE, executa também o CCA e o CJ.

O MSE Capão II chamou a minha atenção já há algum tempo devido ao engajamento de seus funcionários. Por mais que houvesse mudança de funcionários desse serviço, sempre encontrava seus "técnicos" nas atividades do CDHEP, em reuniões de articulação na região, atividades culturais ou de coletivos locais, com posicionamentos que se diferenciavam de outros profissionais das políticas sociais por seu "engajamento".

A equipe do MSE Capão II é formada por 12 pessoas, dentre as quais 8 são mulheres e 4 homens. Estão na faixa dos 30 anos de idade e a maioria é moradora da região e com formação em pedagogia, psicologia e artes, cursos muito frequentes entre as pessoas que atuam no campo da "gestão social". Suas trajetórias também coincidem com o perfil dos trabalhadores desse campo: são pessoas que completaram a educação básica na rede pública de ensino, a maior parte com educação superior cursada em instituições particulares, pois muitos tiveram acesso ao Prouni. Grande parcela deles possui também um acúmulo de experiências de trabalho na área social e, não raro, engajamento em coletivos ou movimentos sociais.

Minha interlocução maior foi com Sulamita Assunção e Elaine Lima, ambas técnicas do MSE Capão II. Sulamita se autodeclara mulher negra, lésbica e feminista. Sua identidade é componente que faz parte do seu trabalho. Sempre comenta como é difícil pautar a "questão de gênero" com os "meninos". Meninos é uma forma frequente por meio da qual os técnicos se referem aos adolescentes atendidos. Não é moradora da região, embora tenha nascido no Vaz de Lima, Jardim São Luís.

Sulamita é formada em psicologia e hoje faz pós-graduação em ciências sociais na PUC São Paulo. Já trabalhou com teatro do oprimido, atuou também em uma penitenciária feminina e agora completa dois anos no MSE Capão II. Segundo a fala de seus colegas de trabalho, mesmo não sendo coordenadora, Sula, como gosta de ser chamada, exerce grande influência no serviço, trazendo grandes mudanças "políticas" e, consequentemente, nas atividades de atendimento, para o MSE.

Inclusive, num dos dias em que fui ao MSE, acontecia uma atividade junto aos adolescentes, o Ocupa Quinta, criado para a discussão de temas diversos, em que coletivos e ativistas da região são convidados para realizar ações junto aos adolescentes. No dia da minha visita o coletivo Juventude e Resistência fazia uma conversa sobre "genocídio do povo 
negro".

Neste dia tive uma conversa com alguns dos técnicos do serviço com a participação de Andrea, ativista da região com muitos anos de experiência em medida socioeducativa. Da conversa participaram, além de Sulamita, Elaine e Luis Fernando, também técnico do serviço. Elaine é moradora da região. É considerada a pessoa mais importante no que se refere ao “conhecimento local”. "Ela conhece tudo por aqui!", dizem. Mãe de um adolescente de 14 anos, Elaine também se autodeclara negra. E, assim como Sulamita, a questão de sua identidade é fundamental para a sua postura no trabalho, identificando-se com as famílias dos adolescentes atendidos. Formada em pedagogia, ela já foi agente comunitária de saúde e educadora no SPVV (Serviço de Proteção a Vítimas de Violência), mas foi apenas no MSE que ela começou a se questionar sobre o seu lugar e a sua relação com esse "público atendido", bem como sobre as divisões e categorias estabelecidas pela política:

Quando eu passei no processo seletivo daqui eu tomei um soco na cara para saber o que é a vida. Para mim foi uma coisa muito real, foi colocar o pé no chão. Isso é vida real! Eu sempre ficava pensando: eu poderia estar aqui, eu poderia estar do outro lado! Porque meu filho é adolescente, porque meu filho fica na rua, anda com todo mundo. Meu filho cresceu no Capão Redondo. Meu filho é negro, é pobre, é periférico! Nos outros serviços eu tinha essa identificação, mas nunca falei para ninguém. Não tinha essa abertura. Porque sempre me foi dito que a gente tinha que fazer um vínculo, mas não abraçar. Eu tinha que fazer um vínculo com o trampo, atender para fazer o encaminhamento, sei lá. Nunca me foi dito como fazer esse vínculo. Mas aqui [no MSE] sempre se falou em vínculos. Até de a família se vincular ao serviço, ao menino. Como eu crio esse vínculo pensando no que eu estou pensando? Que eu também poderia estar do outro lado? Agora é que estamos começando a falar sobre essas coisas. Este momento está sendo libertador. (Elaine)

Nesta fala, Elaine traz o desconforto em ter de "desconsiderar" ou "disfarçar" a identificação que estabelecia com os sujeitos que ela atendia em outros serviços. Tal identificação se dava a partir de sua condição racial, econômica e da experiência compartilhada pelo lugar de moradia, sugerindo a proximidade e não o distanciamento proposto pelo "vínculo" institucional - a ideia de que "eu poderia estar no lugar dessa pessoa".

Luis Fernando, também técnico do MSE, começou a falar sobre sua trajetória identificando-se com os adolescentes que atende e contanto sobre sua inserção no campo da "gestão social": 
Sempre morei na região do Jardim Ângela, no Alto do Riviera, Nakamura. Eu ficava muito na rua, inclusive dormia na rua. Se fosse hoje, eu seria um "LA" também. Minha trajetória na área social e em movimentos começou quando meu irmão era zelador em um condomínio e conseguiu uma vaga para eu trabalhar como auxiliar de limpeza nesse condomínio. Eu fui, fiz a ficha, passei, fui num dia e no outro dia eu não fui, desisti. Daí fui muito criticado pela minha família, apedrejado legal. Nessa época, eu dançava dança de rua e minha mãe me perguntou:

- O que você vai fazer da sua vida? Surgiu um emprego para você, você não quer...Vai ficar aí com esse monte de vagabundo? Está usando droga já? Está pensando em roubar?

Aí eu falei que ia dar aula de dança, trabalhar com dança de rua. Eu menti uns dois meses dizendo que tinha arrumado um trabalho, mas só ia ensaiar com o grupo. Até que um dia fui fazer um show com o grupo e o presidente da Santos Mártires me convidou para dar aula de dança de rua. Daí comecei, agora era oficial. (Luis Fernando)

Uma vez contratado como arte-educador - função muito comum em ONGs e serviços sociais - pela Santos Mártires, Fernando desenvolveu também a habilidade em desenho e o interesse no grafite, assumindo também essas aulas na instituição. A partir dessas atividades, fez graduação na Faculdade Belas Artes. E é técnico do serviço de medida há 6 anos.

Depois de um tempo, entrei no MSE em 2010. Sem saber nada de medida socioeducativa, chegava lá, fazia uns grafites com os moleques. Quando eu cheguei aqui ninguém me ensinou nada, me explicou nada. Tô aprendendo de verdade agora. Eu trabalhava com medida, mas tinha a visão muito engessada, a de como encaixar o menino no relatório. Tem muita coisa para ser trabalhada. Quando eu comecei a entender isso, eu comecei a entender o meu passado. Eu comecei a entender que eu poderia ser um menor infrator. Que eu infracionei diversas vezes, só não fui pego. Quando eu comecei a me compreender, eu comecei a entender o ser humano que entra aqui. Eu não era um sujeito de militância, eu fazia um relatório engessado invisibilizando novamente esse menino, eu era colaborador do sistema. (Luis Fernando)

As trajetórias de Sulamita, Elaine e Luis Fernando contam muito sobre os processos sociais vividos na periferia e a constituição dos sujeitos a partir desses processos. Todos eles nascidos depois da década de 1980, tiveram acesso à educação básica e, na juventude, a uma rede de ONGs e serviços públicos, que se consolidava em meados da década de 1990. Se não chegaram a usufruir desses equipamentos como "atendidos", deparavam-se com um campo de trabalho que não só oferecia um emprego, mas também a possibilidade de construção de trajetórias profissionais coerentes com interesses ou tendências políticas. Aqui, não pretendo 
afirmar que se tratem de trabalhos estáveis e bem remunerados. Muitos são os casos de profissionais que acumulam dois trabalhos - professores de escolas públicas em um período, técnicos de serviço de medida em outro, por exemplo. Mas, conversando com muitas dessas pessoas, sobretudo aquelas presentes nesta pesquisa, o trabalho "é mais que um emprego": nele, os sujeitos se constituem a si mesmos. Existe um sentido, mesmo frente à precariedade, mesmo frente ao sentimento de impotência e isolamento. Existe uma identificação de classe, raça e gênero muito forte com aqueles que são "atendidos", tensionando, muitas vezes, categorias, lugares, divisões e papéis atribuídos pelas políticas.

\section{O PIA, plano de atendimento individual}

O PIA (Plano Individual de Atendimento) tem de 5 a 6 páginas, pra quê? Para burocratizar mesmo a relação! Perguntando um monte de coisas para o moleque. O psicólogo nem vê essa possibilidade de fazer clínica. É só assinar mesmo. Assinar o LA. E aí, senhora, vim assinar o LA! Você abre a porta para o mano e o mano: E aí, tudo bem? Tudo bem! Conseguiu emprego? Tá indo para a escola? E pronto. Muitas vezes é isso, o atendimento se resume a isso. Aí a família vem e participa de uma oficina assim: "A importância do vínculo familiar para o jovem". E daí se dá uma lavada na família. Que a família não acompanha o menino, culpabilizando mais ainda a família. Principalmente as mães, porque são elas e as avós que estão lá. Não tendo outra pegada sobre qual é o problema mesmo, o que tá faltando na vida do adolescente e da família. E foi piorando quando se troca o nome de educador, com a mudança na portaria, para técnico. Quando você põe este nome, "técnico", a distância fica maior ainda (Andrea)

Embora o Sinase indique as diretrizes de atendimento para os serviços de medida socioeducativa e exista o Creas, que seria, na hierarquia do Estado, o responsável em apoiar e supervisionar as práticas para que estas fossem seguidas, vários técnicos com quem eu conversei afirmaram que há uma enorme diversidade na forma em que esses atendimentos são feitos. "Cada um faz o que quer" afirmou Sulamita. E muitos detêm-se apenas na exigência burocrática de preencher os relatórios, como expresso na fala de Andrea acerca de assinar a "LA".

Mas algumas "orientações" são básicas para que a medida seja considerada como cumprida. São elas: comparecimento ao MSE, frequência escolar e formação ou inserção no trabalho. São o que os técnicos do Capão II chamam de "caixinhas" do relatório - isto é, os campos para cada uma destas dimensões que são padronizados no relatório. Caso o adolescente não esteja indo à escola ou procurando trabalho, tampouco comparecendo ao 
serviço, a medida é considerada descumprida e ele pode voltar ou ser encaminhado para a internação.

De acordo com Andrea, que já trabalhou em um SME por mais de 5 anos, e Sulamita, referindo-se às práticas de atendimento que encontrou quando chegou ao MSE Capão II, grande parte dos serviços de medida resume suas práticas ao atendimento individual no sentido de aplicar o PIA, Plano Individual de Atendimento. O PIA é um instrumento previsto no Sinase, constituindo-se, conforme este documento, numa "importante ferramenta no acompanhamento da evolução pessoal e social do adolescente e na conquista de metas e compromissos pactuados com esse adolescente e sua família durante o cumprimento da medida socioeducativa” (Sinase, 2006). A elaboração do PIA se inicia na acolhida do adolescente no programa de atendimento. O requisito básico para a sua elaboração é a realização do diagnóstico "polidimensional," por meio de intervenções técnicas junto ao adolescente e sua família, nas áreas:

a) jurídica: situação processual e providências necessárias; b) saúde: física e mental; c)psicológica (afetivo-sexual): dificuldades, necessidades, potencialidades, avanços e retrocessos; d) social: relações sociais, familiares e comunitárias, aspectos dificultadores e facilitadores da inclusão social, necessidades, avanços e retrocessos; e) pedagógica: escolarização, profissionalização, cultura, lazer e esporte, oficinas e autocuidado. Enfoca, assim, interesses, potencialidades, dificuldades, necessidades, avanços e retrocessos. Registra as alterações (avanços e retrocessos) que orientarão na pactuação de novas metas. A evolução ou crescimento pessoal e social do adolescente deve ser acompanhada diuturnamente, no intuito de fazê-lo compreender onde está e aonde quer chegar, e seu registro deve se dar no PIA (Sinase, 2006, p. 52).

Para alguns estudiosos desse campo, oriundos de áreas diversas, a aplicação do PIA é considerada um avanço nas medidas socioeducativas no sentido de individualização da medida, visando, ao mesmo tempo, garantir os direitos dos adolescentes e considerar a sua singularidade. Favorece, assim, o "processo de tomada de responsabilidade pelo ato infracional cometido" (Moreira e col., 2015, p. 344).

Essas interpretações, bem como os instrumentos da medida socioeducativa, reforçam a ideia de responsabilização individual tanto do adolescente quanto de sua família. Responsabilizando-os não apenas pela infração, mas também por certa incapacidade em acessar uma rede de políticas e instituições que já estaria presente no território. A medida socioeducativa seria, então, o mecanismo de "fortalecimento" dos vínculos familiares e 
acesso a essa rede, além de permitir a promoção de uma "autorreflexão" do adolescente, isto é, uma "tomada de consciência" a cerca do ato cometido.

Assim, para os técnicos do Capão II, o preenchimento do PIA é, na prática, muito mais um mecanismo burocrático de atendimento do que de fato um documento que possibilite o acompanhamento da "evolução pessoal" - sobretudo porque esta evolução, no documento, deve dar-se a partir das "caixinhas", como dizem. Trata-se de um procedimento "quase mecânico de atender o menino, fazer o relatório se sair", afirma Sulamita.

O roteiro do PIA utilizado no MSE Capão II é o que segue:

- Avaliação interdisciplinar: refere-se à relação que os adolescentes estabelecem com as políticas de educação, saúde e assistência social;

- Objetivos do adolescente: remete aos planos que o adolescente tem para o seu futuro mais imediato, em torno do qual as atividades irão se desenvolver (aqui, vale ressaltar que tais planos devem estar relacionados à escolarização, à formação profissional e à inserção no mercado de trabalho);

- Atividades de integração e capacitação: participação em cursos e atividades oferecidas pela rede local (ONGs, serviços das políticas sociais, lazer etc.);

- Atividades de integração, apoio e participação das famílias

- Responsabilização quanto ao ato infracional: como o jovem atendido se coloca frente ao ato cometido;

- Encaminhamentos: refere-se aos encaminhamentos do caso propostos pelo técnico para a rede das políticas sociais locais;

- Parecer de atendimento: avaliação final do cumprimento da medida.

A tônica de todos os documentos que orientam essa política e a organização PIA expressam o esforço de normatização dos adolescentes que cometeram ato infracional: escolarização, inserção no mercado de trabalho, reforço dos vínculos familiares, arrependimento pelo ato cometido.

Para Sulamita, mesmo engessado, esse relatório também pode ser um "espaço de luta", em que é possível fazer denúncias e tornar explícitas as contradições, como problematizar a exigência da empregabilidade na medida mesmo havendo poucos empregos disponíveis para jovens negros e pobres, sobretudo aqueles com o estigma do "LA", afirma a técnica.

Mas tais denúncias no relatório não serão necessariamente consideradas em um parecer 
favorável ao adolescente. De acordo com Andrea, se o serviço e seus técnicos começarem a "aparecer demais", sendo muito "permissivos" ou questionando em demasia os princípios que orientam a medida, podem haver consequências não só para os técnicos, mas também para a instituição executora.

O PIA não teria espaço, dessa forma, para expressar as condições em que o serviço de medida socioeducativa é executado, nem as várias dimensões e possibilidades de vínculos construídos no atendimento, tampouco a presença da violência do Estado, sobretudo a policial. Vamos observar o parecer de um PIA:

"A partir da Constituição Federal de 1988 e do ECA, as crianças e adolescentes brasileiros passaram a ser vistos como cidadãos, aos quais se deve garantir direitos fundamentais (vida, educação, saúde, escola, respeito, dentre outros)."

No entanto, está claro que Jorge, em situação peculiar de desenvolvimento, não possui esses direitos garantidos, conforme rege a nossa legislação.

O adolescente em questão tem dificuldades para acessar a educação, conforme já exposto, com isso, enfrenta oportunidades desiguais frente ao mercado de trabalho, além das diferenças sociais e econômicas que atravessam a vida pessoal e familiar.

Sabemos que é de responsabilidade do Estado, sociedade e família o cuidado com a criança e o adolescente, então, o fato é que Jorge, sozinho, terá mais dificuldade em superar toda a adversidade em meio a dificuldades que permeiam o meio em que vive.

O curso profissionalizante estava contribuindo efetivamente com a reflexão sobre seu futuro. No entanto, foi necessário se ausentar, devido ao acidente com o seu braço e a falta de uma data de agendamento próxima para que seu tratamento fisioterápico fosse mais rápido e efetivo. $\mathrm{O}$ adolescente conseguiu, no posto de referência de sua residência, agendamento para ser atendido somente em fevereiro de 2016, sendo que o acidente ocorreu no final de novembro.

O adolescente relatou que gostava bastante dos temas abordados e da dinâmica do professor. Nos atendimentos, relatava de maneira empolgada sobre as suas notas na prova e o que tem aprendido. Cabe ressaltar que esse curso estava sendo de extrema importância para que o adolescente tivesse um espaço para exercitar o seu intelecto e ocupar o seu tempo de maneira útil, já que não havíamos conseguido a matrícula na escola. Em conversa com a Sheila da coordenação do curso na $\mathrm{AEB}$, não havia nenhuma queixa quanto à participação do adolescente. Durante esse período, Jorge sempre abordou a questão da matrícula da escola, interessado em sua reinserção e conclusão do ensino médio.

Sabemos que não há um único fator que leva os adolescentes a cometerem atos infracionais, no entanto, o fato é que o adolescente fora da escola e exposto a situações de risco que a região oferece está mais 
vulnerável a cometer atos antissociais. $\mathrm{O}$ adolescente está tentando superar a fase difícil em que se encontra; perda do pai, dificuldade financeira, diferenças econômicas, sociais e, além disso, pertencimento a outro grupo de adolescentes, que não seja o dos amigos "que levem para o mal caminho" (sic). No entanto, devido a sua fase de desenvolvimento, certamente terá mais dificuldade se estiver sozinho, por isso, é fundamental que a família, a sociedade e o Estado, em parceria com as instituições, facilitem o acesso à educação, saúde, trabalho e lazer que lhe é de direito.

Aos poucos, estamos buscando aproximá-los de temas pertinentes às necessidades expressadas, bem como inseri-los na rede de serviços, para que tenham válidas contribuições no enfrentamento da realidade apresentada. Entretanto, esbarramos na falta de políticas públicas adequadas e suficientes para atingir os objetivos do Plano Individual de Atendimento.

Por esse motivo, o adolescente continuará sendo acompanhando na Medida Socioeducativa de Liberdade Assistida. (PIA - Jorge, Parecer de atendimento)

A técnica que elaborou este PIA inicia o texto mobilizando as contradições entre as leis e a realidade dos jovens. Reafirma a dificuldade que o mesmo encontrará em enfrentar tais contradições sozinho, reforçando a necessidade do apoio do Estado, da família e da sociedade. Chama a atenção a importância que o acesso às instituições, aos equipamentos públicos e ao trabalho assume neste relatório, como nos documentos normativos em geral das políticas sociais, enquanto lugar privilegiado de proteção e efetivação de direitos. Contudo, ao mesmo tempo ressalta-se que tais instituições, equipamentos e trabalho são precários, sendo os "LA", como são chamados os adolescentes cumprindo medida, muitas vezes "indesejáveis" nesses lugares. Mesmo argumentando sobre o contexto institucional desfavorável para a "inclusão social" do adolescente, o relatório propõe a continuidade da medida, entendendo o serviço como o apoio necessário para o acesso aos direitos.

Alguns autores têm se detido no aspecto normativo das medidas socioeducativas. De acordo com Maurício Gonçalves Saliba:

O caráter educativo proposto pelo Estatuto da Criança e do Adolescente, que se expressa por meio de suas medidas socioeducativas, tem por objetivo camuflar e dissimular uma estratégia historicamente elaborada de vigilância e controle coercitivo do comportamento das crianças e adolescentes em conflito com a lei. Para isso, deve-se desvendar a estratégia, comandada pelo Poder Judiciário, de controle e vigilância sobre o adolescente infrator em liberdade que recebeu como pena a medida de liberdade assistida. (Saliba, 2016, p. 20)

Em seu livro, O Olho do Poder, busca demonstrar como a intervenção judicial pretende normatizar o comportamento do infrator e de sua família sob o véu da educação. Isto é, 
examiná-los e provocá-los a uma mudança comportamental. Caso esse projeto normatizador não seja concluído, o adolescente, e consequentemente a sua família, serão alvo de vigilância e - eu incluiria - de violência do Estado, até a maioridade.

Saliba nos oferece uma interpretação para não apenas observar os documentos normativos das medidas socioeducativas, mas também analisar as práticas e os discursos no cotidiano. Esse projeto normatizador tem por fim delimitar as fronteiras entre o "jovem trabalhador" e o "bandido" (Feltran, 2010). Assim, o adolescente que passasse a frequentar a escola e a trabalhar teria um parecer favorável na medida - mas apenas nela, pois as condições sociais que o levaram à infração permanecem. Além disso, esse sujeito possui agora uma "passagem", aumentando seus riscos de sofrer com a violência policial.

No entanto, tendo a problematizar um pouco mais o cotidiano na "ponta" da medida socioeducativa em meio a esse enfrentamento cotidiano em torno das medidas. Neste contexto, a produção do "sujeito perigoso" é bem mais complexa e a vigilância do Judiciário se desfaz de certa forma devido à precariedade da execução. Mas isso não significa uma diminuição da violência do Estado - ao contrário, a polícia, mais do que o Judiciário, está na periferia fazendo "justiça” a partir de seus critérios e com suas próprias mãos. Ativistas e alguns profissionais das políticas sociais agem no sentido de resistir a esse processo, embora também sejam alvo de desqualificação e violência.

\section{Sujeitos perigosos, serviços perigosos}

Existe uma vasta bibliografia sobre as ações do Estado voltadas para a infância e a adolescência pobres apontando o caráter higienista, punitivo e estigmatizador dessas práticas (Rizzini, 1997; Sales, 2006; Teixeira, 2012; Vianna, 2001). Assim, ao longo do século XX termos como infância degenerada, delinquência, menor, bandido foram empregados para designar o sujeito que passou a ser reconhecido como perigoso: jovens, sobretudo do sexo masculino, negros e pobres. E ações de violência arbitrária seriam justificadas pelo risco que tais sujeitos ofereceriam à sociedade.

No período de produção desta dissertação, Ítalo, um menino de 10 anos, foi assassinado por policiais quando furtava um automóvel no Morumbi. Ítalo era morador do distrito da Vila Andrade, uma das regiões mais constrangedoramente desiguais do país, conforme apresentado nos capítulos 1 e 2. Os argumentos utilizados pelos policiais militares envolvidos no caso eram de que o garoto, no momento da fuga, disparara contra a viatura enquanto dirigia, 
caracterizando "morte por confronto com a polícia". Esse argumento foi rapidamente refutado pela perícia, tendo em vista o tamanho e a habilidade de uma criança com tal idade de realizar esse feito. O processo continua em andamento, mas o que pretendo destacar aqui são as reações geradas pelo episódio. Por um lado, a indignação de ativistas, sobretudo aqueles que atuam em movimentos sociais que denunciam o "genocídio dos jovens negros", por outro lado, moradores da região que, cansados de tantos assaltos, apoiaram a ação da polícia.

Sem a menor comoção por se tratar de uma criança, um grupo de moradores se organizou para ir até o palácio do governo, em uma manhã de sábado, a fim de agradecer e parabenizar a ação da polícia. Movimentos sociais também estiveram presentes no dia para se opor à manifestação desse grupo de moradores. Com fotografias de jovens assassinados pela polícia, exibiam faixas acusando a polícia e o governo estadual de racistas e assassinos.

Este episódio ilustra bem a polarização de discursos e práticas que estão em jogo nesse campo das ações do Estado voltadas para jovens na periferia, dentre elas os serviços de medida socioeducativa. Assim, além dos documentos normativos que orientam os serviços, como apresentado acima, seus profissionais são também influenciados por esse campo discursivo dinâmico e conflituoso. O fato de o adolescente não estar frequentando a escola pode gerar ou um parecer negativo, que poderá contribuir para a internação do mesmo, ou um parecer positivo, justificando a não frequência a partir da precariedade e da insuficiência das políticas sociais, como no caso de Jorge. Isso dependerá do técnico.

A experiência de marginalização e violência policial vivida pelos jovens pode também ser vivenciada pelos técnicos, dependendo do posicionamento dos mesmos frente às abordagens que, inclusive, são frequentes próximo a esses serviços, uma vez que são ostensivamente vigiados. Ouvi vários relatos de profissionais que correram o risco de "enfrentar" a polícia para proteger os adolescentes.

Eu passei por uma situação quando estava grávida da Sofia. Os moleques estavam saindo da aula com um cavaquinho na mão. Não deu nem dois minutos e a educadora que trabalhava comigo veio me avisar que a Rota tinha parado os moleques. Eu disse: - A Rota? Quase que eu não conseguia andar com o barrigão. Daí fomos eu, o Claudinei, mais a educadora e três ou quatro pessoas. Quando eu abri o portão, o policial soltou o menino. Aí ele pegou e a falou: - O que é que foi, senhora? Aí eu falei assim, que queria saber o que é que estava acontecendo, pois os meninos tinham acabado de sair aqui do curso. Só queria saber se fizeram alguma coisa. O policial respondeu que era apenas rotina. Então eu quero acompanhar a rotina, respondi. Aí ele começou a dizer que os moleques eram muito folgados. A boca do cara espumava. Aí ele olhou para o Claudinei e disse: - E você, é 
quem? O Claudinei respondeu: - Eu sou educador. O policial respondeu que ele deveria ter no mínimo umas três, quatro passagens pela cara de educador. Porque o Claudinei era negro. E o Claudinei respondeu que tinha três ensinos superiores. Aí ele falou um monte e disse: - Vamos levar todo mundo para o DP! Eu falei: - Vamos para o DP! Aí eu falei: - Néia, traz minha bolsa aí que nós estamos sendo presos. Eu pensei que fosse parir naquele carro. (Andrea)

Esta situação fica ainda mais dramática quando esses técnicos não contam com o apoio da "rede de proteção" prevista no ECA - nem para os adolescentes, nem para eles mesmos. Andrea e seus colegas de trabalho não contaram com o apoio nem da instituição, nem do Creas. No momento em que interferiram no trabalho da polícia, praticaram uma ação que não estava prevista nos fluxos e protocolos burocráticos da política. Eles agiram nas fissuras do Estado (Deleuze e Guattari, 1997), subvertendo os procedimentos previstos e arcando, individualmente, com as consequências.

Mas não é apenas a violência policial que os técnicos experimentam trabalhando com os adolescentes em medida socioeducativa. Grande parte dos equipamentos das políticas sociais apresenta resistência em atender a esses adolescentes. Escolas, ou mesmo equipamentos da assistência, estigmatizam ou excluem os jovens das atividades. Os profissionais de medida afirmam que é necessário se esforçar para sensibilizar os equipamentos, muitas vezes os da própria assistência social. Provar que o jovem não é agressivo, que não roubará, que não causará problemas. Sulamita fala sobre o caso de uma adolescente:

Quando você vai inserir o adolescente em um curso que é da assistência, a coordenadora começa a fazer entrevista com o adolescente, perguntando: Qual foi seu ato infracional? Isso é real gente! Começa a entrevistar a família: - Qual foi o ato infracional? Por que ele cometeu? Tem uma adolescente que eu coloquei num curso. Aí a adolescente saiu do espaço e falou: - Eu não vou ir para o curso pra todo mundo ficar me olhando, não vou ir para o professor ficar me olhando, não falar comigo, ninguém fala comigo. E é uma adolescente supercrítica, pra frente, a gente conversa sobre várias coisas. Ela tem uma consciência. Então que direito tem uma coordenadora de fazer uma entrevista com a mãe perguntando do ato infracional?. Aí a adolescente faltou porque ela tem uma irmã pequena que estava doente e não pode ir para o CCA. A mãe ligou para avisar. No dia seguinte ela faltou de novo e a coordenadora ligou para a mãe falando que a adolescente tinha que ir para o curso, senão mandaria prender ela. Tomo mundo pode prender este adolescente! (Sulamita)

Fernando, técnico também do serviço, afirma que muitos desses adolescentes em 
medida já eram usuários do CCA (Centro de Crianças e Adolescentes) ou do CJ (Centro de Juventude) antes do ato infracional. Mas, até então, passavam invisivelmente pelo sistema, na sua condição de vítima. Quando há mudança de vítima para agressor, esse sujeito começa a ser visto como "bandido", não mais "desejável” no equipamento:

\begin{abstract}
Nesses serviços, em relação ao próprio Saica [Serviço de Acolhimento Institucional de Crianças e Adolescentes] e ao SPVV [Serviço de Proteção a Vítimas de Violência], que trabalha a vítima, se você for ver, o adolescente que está no LA é até mesmo muito mais vítima do que aquele que está sendo atendido no SPVV, mas, por conta do ato infracional, é como se acabasse tudo. Vamos desconsiderar todo o contexto histórico daquele adolescente e de sua família e vamos considerar só o ato infracional. Quando ele passa a violar o sistema, passa de violentado à violador, a própria instituição faz o trabalho de exclusão dele. (Fernando)
\end{abstract}

A fala de Fernando chama a atenção para um aspecto importante, que é essa passagem do "atendido" de vítima para agressor. Vítima invisível, que passa a ser vista somente após o ato infracional, quando se torna "perigosa" e, assim, não desejável. A partir de então, o adolescente, assim como a sua família, passam a ser estigmatizados. Essas contradições ficam explícitas nas situações-limite de atendimento envolvendo outros equipamentos:

Recentemente, a gente foi em uma reunião com o abrigo. Uma mãe está sendo atendida aqui porque dois filhos dela estão em medida socioeducativa. O filho dela foi abrigado também. E a mãe, quando entrou no serviço, estava num movimento mesmo de negligência. Mas, agora, ela está retomando isso aqui. E ela não adere ao Saica. Não é porque aqui é melhor, é porque as pessoas aderem a um serviço e não a outro. E os serviços não são articulados para saber o que os outros serviços fazem. Aí ficam numa disputa egoica, em que a gente teria de afirmar que a mãe é realmente negligente, trabalha com prostituição etc. (Sulamita)

O que estes episódios sugerem é que, embora existam serviços sociais referenciados a uma política, coordenados por um mesmo equipamento e executados por instituições sociais que muitas vezes possuem trajetórias de "luta" na região, não há um trabalho coordenado de rede, como preconizado pelos documentos normativos, tampouco orientado pelos mesmos princípios. Assim, a rede não é um pressuposto normativo - ao contrário, ela é tecida espontaneamente, seja pelos sujeitos atendidos, seja por afinidades políticas e técnicas entre sujeitos e instituições, e não a partir de um fluxo institucional estável.

Os funcionários do Capão II reclamam do isolamento, referindo-se não somente à 
dificuldade da relação cotidiana com os adolescentes atendidos. Eles falam de questões sociais mais amplas que não só levaram o sujeito à infração, mas também contribuíram para a produção da infração, além dos processos de construção do estigma. Estigma esse que se estende para as famílias dos jovens e, também, para os próprios serviços.

Eu percebo que, em relação a alguns lugares em que eu trabalhei e alguns lugares que eu visitei, este serviço é um serviço marginalizado nas instituições também. Por exemplo, eu fui em uma instituição do Jabaquara e quando cheguei a instituição era linda, parecia que você estava chegando em outro lugar, um casa de campo. Eu falei: - Gente, que lugar lindo! Eu fiquei deslumbrada. Aí eu perguntei: - Gente, onde é o serviço de medida socioeducativa? O cara falou para mim: - Você pega essa rua aqui, aí quando chegar no final tem uma escada, você vai descer. Quando eu cheguei no lugar, parecia um porão! Era um chão com carpete, uma forração, um cheiro de mofo! Eu não aguentei ficar lá dentro. Imagina, o povo chega, os meninos chegam, a família chega naquele lugar lindo. Mas isso aqui não é pra vocês. Vocês vão tudo para o inferno, para o calabouço. (Andrea)

É muito curioso tal isolamento mesmo existindo duas instâncias de coordenação: a instituição executora e o Creas. Segundo Sulamita, a relação com o Jardim Comercial é completamente distante: "A gente faz o que quer, não existe nenhum direcionamento. Se a gente quiser fazer uma palestra sobre como a polícia é uma boa, a gente pode. Se a gente quiser fazer uma palestra sobre a legalização da maconha, também pode".

Quanto ao Creas, a supervisão é apenas burocrática. Segundo os técnicos do Capão II, deve-se apenas entregar os relatórios, atendendo aos requisitos estipulados - "preencher as caixinhas" -, mas discussão sobre conteúdos e encaminhamentos são inexistentes, afirmam.

Para Sulamita, essa falta de direcionamento e isolamento é um grande problema, sobretudo em termos "políticos". Para ela, existem diversas instâncias de "luta" para a melhoria do serviço, para a ampliação do repertório de técnicas e as possibilidades de atendimento, assim como o monitoramento da implementação da própria política, pressão de outros órgãos do Estado, como o FAS (Fórum de Assistência Social, regional e municipal) e a Rede de Articulação dos Serviços de Medida Socioeducativa. Estas instâncias, afirma, foram e são fundamentais para a mudança de seu entendimento sobre as medidas socioeducativas e para o aprofundamento no Sinase. No entanto, a participação é voluntária, sendo decisão do técnico participar ou não. Além disso, não existem mecanismos internos para partilhar discussões e decisões tomadas nesses lugares. Não se trata da representação do serviço, mas sim de uma participação individual, afirma. 
No entanto, foi participando dessas atividades "de fora" do serviço que muitos técnicos começaram a perceber as possibilidades de transformar o atendimento. E recorrer "para fora" é uma maneira de lidar com essa sensação de isolamento expressa pelos técnicos do MSE Capão II. Sobretudo a partir da identificação política entre tais segmentos e os profissionais: participação na rede de articulação dos MSEs, no GT de Violência, no CDHEP e, mais recentemente, nos coletivos de jovens da região.

\section{Tensões, resistências e horizontalidade}

Com o intuito de realizar novas formas de "atendimento" que escapassem da burocracia do relatório, saindo das "caixinhas", como eles dizem, a equipe do MSE Capão II buscou uma aproximação entre os adolescentes "atendidos" e as práticas e os discursos produzidos por coletivos locais. Criaram para isso o Ocupa Quinta, nome que faz alusão às ocupações que estão ocorrendo nas escolas públicas e equipamentos de cultura na cidade. O objetivo do Ocupa Quinta é aproximar os jovens que estão cumprindo medida socioeducativa de outros jovens da região que estivessem engajados em coletivos. Fazem, inclusive, uso do Sinase para justificar essa atividade nos relatórios dos adolescentes - isto é, para que a atividade seja considerada quando for avaliado o cumprimento da medida.

Nas tentativas de aproximação entre coletivos, jovens atendidos e técnicos, parece acontecer certa flexibilidade na relação técnico e atendido, surgindo outra figura, que é a do ativista. Parece uma tentativa de (re)estabelecer relações mais próximas, que buscam outros pressupostos para se constituir: a experiência de morar na periferia, a identidade racial, de gênero e sexualidade. Identificações que já existiam, mas eram silenciadas.

Quando Elaine, técnica do MSE Capão II, fala sobre a sua identificação com as mães e os adolescentes que estão sendo atendidos no serviço, ela está desestabilizando os lugares impostos pela política, que definem o tipo de relação a ser construída e seu lugar nela - uma relação hierarquicamente desigual, em que ela possui não apenas o saber técnico, mas também o poder de influenciar na decisão sobre a continuidade ou não da medida e, até mesmo, sobre uma possível internação. Sua condição racial, autodeclarada negra e "periférica", permite essa identificação. Contudo, esse processo não é espontâneo, senão emerge a partir de um campo discursivo de valorização dessas identidades. Elaine fala de como, antes, quando entrou no MSE, ela sentia essa identificação, "pensava sobre muitas coisas", mas ficava tão constrangida com o coordenador anterior, o qual "falava com tanta 
autoridade, sabia tanto", que ela se calava - ainda que ele fosse uma pessoa que não "conhecia nada da realidade local", por ser um homem branco de classe média que não morava na "quebrada". Ela fala sobre o seu processo de "empoderamento":

Se você ficar muito aqui, você fica aqui. Você não consegue pensar fora da caixinha. Daí eu começo a ter um outro movimento quando começo a sair. Primeiro eu começo fazendo um curso na USP sobre mulheres negras em São Paulo. Daí consegui entender quem eu sou e qual a minha trajetória. Eu sabia que eu era negra, sempre soube que eu era negra, mas qual era a importância? Qual era a minha história? Eu não conhecia a minha história. E, a partir do momento em que eu começo a conhecer minha história, minha identidade, de onde eu vim, você vai ficando empoderada, você vai tendo conhecimento e conseguindo falar as coisas. Eu não tinha espaço, mas agora dá licença, que eu quero falar! (Elaine)

Estes discursos de valorização da identidade "negra" e "periférica" vão sendo reforçados por coletivos, movimentos sociais e articulações na periferia. Quando cheguei à zona sul, há 5 anos, tinha a impressão de que se tratavam de dois campos diversos: de um lado, os coletivos, sobretudo os saraus, na época em maior evidência, que produziam esse discurso valorizado da periferia; e, do outro, as políticas sociais, seus técnicos e suas articulações. Nos últimos anos, além da multiplicação de coletivos que articulam as discussões sobre raça e gênero, minha impressão é a de que esses sujeitos começam a se aproximar e a se influenciar mutuamente. Evidentemente, não é uma regra geral, mas um processo visível.

E essa identificação, esse empoderamento têm impacto direto na construção do "vínculo" com os "atendidos" e na transformação dessa relação. Aqui, há talvez uma tendência em flexibilizar os papéis rígidos estabelecidos pela política, aproximando-se das relações mais horizontais que constituem os coletivos e os movimentos sociais.

Assim, o "vínculo" estabelecido entre "técnico" e "atendido" é um lugar perigoso. É o lugar de encontro entre esses sujeitos, que pode reforçar hierarquias ou subvertê-las. É o que sugere a fala de Elaine sobre o seu desconforto por não conseguir se adequar a seu papel técnico, que pressupõe um tipo de "vínculo" com o "atendido" não tão definido, mas de certa forma "distante" - mais distante do que o tipo de vínculo que ela estabelece com seu filho, sua vizinhança, seus parentes. Esse lugar confuso e perigoso é onde os limites do Estado podem se reproduzir, se perder ou se desfazer. Vários foram os episódios que presenciei nos 
quais técnicos, não suportando as restritas possibilidades de atendimento oferecidas pelo Estado frente às demandas "reais" de crianças, jovens e suas famílias, rompiam o limite da "vida privada" e do "trabalho": educadoras que levavam jovens para casa; adoções feitas por técnicos; relações que permanecem por anos, tornando-se amizades entre "atendidos" e "técnicos". Isso era muitas vezes visto como um "erro técnico" ou um "escândalo" reforçando o vínculo como lugar sempre perigoso que precisa de controle e vigilância.

Mas não é apenas por meio dos vínculos que se dão as formas e os lugares de rompimento com as categorias e as hierarquias estabelecidas pelo Estado. As articulações horizontais também podem ser um caminho. O lugar de Sulamita também é desconfortável, não no sentido apenas de identidade, mas sobretudo porque ela não consegue se adequar ao tipo de "atendimento padrão" oferecido pelo serviço: atendimento individual e produção de relatórios. E ela só pode dar forma a esse desconforto saindo do serviço, buscando "fora" as referências. Referências estas que estariam ligadas a uma crítica social mais ampla, situando os sujeitos em um contexto marcado por raça, classe, sexualidade e gênero a partir do qual a articulação destes marcadores revelaria a exposição dos jovens a mais ou menos violência, inclusive a que é protagonizada por setores do próprio Estado, seja por meio de violência direta ou por omissão.

Assim, a hipótese que sustento neste trabalho é a de que o Estado se organiza verticalmente, estabelecendo limites e criando categorias que constroem relações entre quem está "fora" e quem está "dentro" de sua estrutura, além de estabelecer múltiplas divisões internas e hierarquias a partir de papéis assumidos e diferenças de poder. A gramática dessa comunicação é a burocracia, a escrita e a autoridade. Produzindo categorias que organizam os sujeitos no espaço social, reforça lugares de poder, de submissão. No entanto esses limites não são fixos e impermeáveis, mas estão sempre em tensão, pois os sujeitos estão em constante movimento.

Os documentos normativos e legais definem uma política alinhada com os mais progressistas princípios dos direitos humanos que circulam em dimensões globais. No entanto, se observarmos a fundo seus pressupostos, há um projeto normatizador, além de uma individualização dos problemas sociais, que recai sobre os sujeitos pobres e suas famílias, sendo a burocracia o mecanismo que permite a reprodução dessas práticas. Além disso, observamos na "ponta" serviço, ou seja, na prática do cotidiano, a precarização, a punição e o descaso com essa população, o que faz com que a política social, que deveria reparar direitos, seja, ela mesma, vetor da violência social.

No entanto essas "pontas", que considero aqui como margens do Estado, são 
permanentemente tensionadas, tanto por "dentro", como por "fora". Existem sujeitos "dentro" da estrutura do Estado, como técnicos das políticas sociais, que constantemente problematizam e subvertem diretrizes a partir de referências de práticas e discursos que estão "fora" do estrutura burocrática.

Chego a esta conclusão a partir do que venho observando no MSE Capão II. A aproximação do Comitê Juventude e Resistência ${ }^{68}$ vem fortalecendo esses lugares de produção de discursos e práticas que tensionam a imposição burocrática da política. Diversas reuniões foram feitas entre os "técnicos" dos serviços e os ativistas do coletivo buscando construir ações coletivas que pudessem aproximar os adolescentes em medida socioeducativa e suas famílias da "luta" contra o "genocídio da população negra, indígena e periférica" - luta esta que será tratada no próximo capítulo. Aqui, a importância é a de ressaltar o processo de articulação envolvendo os "atendidos" dos serviços que, na "luta", juntamente com os técnicos, passam para outra categoria, tornando-se também ativistas.

Nos meses em que finalizava este texto, participei de ao menos quatro desses encontros. A cada reunião, pude observar que as desconfianças entre técnicos do MSE Capão II e ativistas eram minimizadas. Por um lado, os ativistas tendem a desconfiar dos profissionais das políticas por eles agirem de acordo com o "Estado", tendo como preocupação principal a manutenção de seu emprego, e, por outro, os profissionais consideram os ativistas muito "radicais" e "fechados", portanto pouco abertos ao diálogo com quem está "fora" de seu posicionamento político ou coletivo. No entanto, condição "racial", de "gênero" e de morador da "periferia" talvez seja um aspecto de reconhecimento que superariam as diferença nesse contexto de "luta", como será tratado no próximo capítulo.

Além disso, a participação dos "atendidos" era cada vez maior e mais propositiva, com destaque para a participação das mães e das avós dos adolescentes em medida socioeducativa.

$\mathrm{Na}$ última reunião de que participei, o objetivo era o de construir propostas para o enfrentamento de um caso de racismo ocorrido em uma escola municipal da região, cuja vítima era uma menina de 12 anos, sobrinha de uma dessas mães, a Vera. Ela denunciou o caso em uma outra reunião e os participantes propuseram planejar ações para enfrentá-lo. No dia do encontro, apareceram mais mães e adolescentes com mais casos de racismo e, desta reunião, resultaram diversas proposições.

O que pretendo reforçar aqui é que, mesmo que o MSE não tenha conseguido mudanças

${ }^{68}$ Coletivo de jovens que se originou a partir do Plano Juventude Viva - política do governo federal com vistas à prevenção de homicídio de jovens - e que atua na região na "luta" contra o "genocídio da população negra e pobre", tratado com mais profundidade nos capítulos 1 e 5 desta dissertação. 
significativas nos casos de "atendimento" tal qual previstos na política - ou seja, preenchimento de relatórios, enquadramento do jovem nas "caixinhas" de educação e trabalho -, seus técnicos foram tecendo relações e desenvolvendo outras ações e discursos de forma horizontal, junto com ativistas e coletivos locais. Tornou-se um lugar de realização de reuniões, em que as relações entre "técnicos e atendidos" começaram a ser transformadas no sentido de um ativismo fora da hierarquia da política. Uma "luta" que, inclusive, busca enfrentar o próprio Estado.

Neste capítulo, tive a intenção de me aproximar ainda mais das margens do Estado, observando o cotidiano dos sujeitos envolvidos em um serviço público específico, a medida socioeducativa. Busquei perceber como o Estado se impõe a partir de documentos normativos e procedimentos burocráticos que tendem a normatizar sujeitos pobres e suas famílias, responsabilizando-os pela "exclusão social" e, ainda, reproduzindo punição e estigmas. Tal imposição também segmenta, categoriza, classifica e hierarquiza relações. No entanto, mesmo sob essa imposição os sujeitos estão permanentemente resistindo a partir da produção local de discursos e práticas relacionada ao reconhecimento mútuo da experiência compartilhada de violências sociais como racismo, gênero e violência do Estado na periferia. Tencionam-se, assim, constantemente estas margens, como é o caso dos sujeitos envolvidos no MSE Capão II.

No próximo capítulo, acompanho mais de perto a produção desses discursos locais forjados também nestas margens, tendo por fim enfrentar e se proteger da violência do Estado. Observo o processo de surgimento do Comitê Juventude e Resistência a partir do Plano Juventude Viva, política federal implementada pelo município que tem por fim a "prevenção" de homicídios de jovens negros. 


\section{Capítulo 5 - Ações do Estado e ativismo na zona sul}

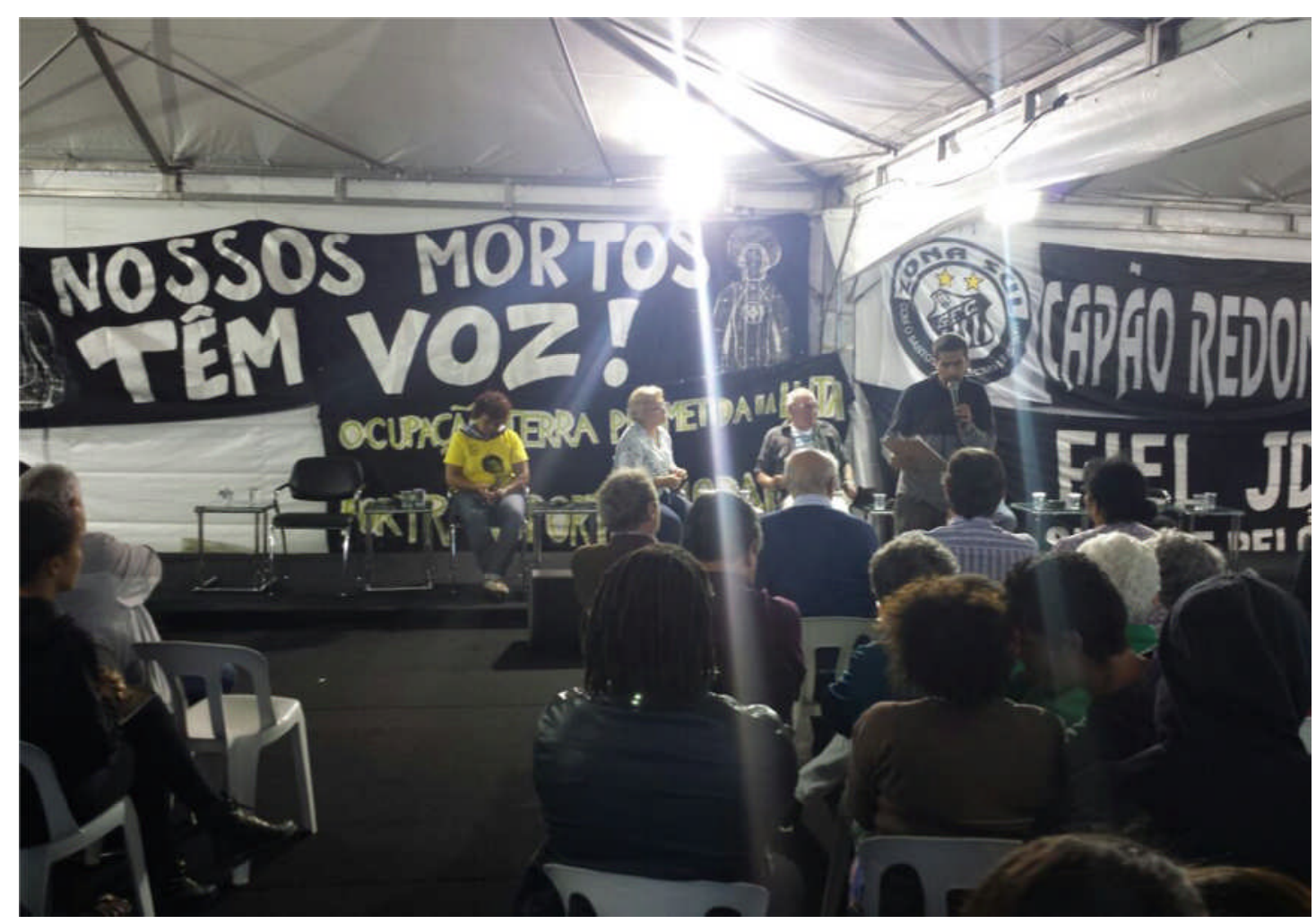

A união da juventude pobre que luta contra o sistema está se construindo. É uma união internacional que junta favelas e quebradas, de ponta a ponta neste mundo, para um combate do qual só podemos sair vencedores, caso contrário é a própria possibilidade da alegria e do futuro que sucumbirão. Não tenho dúvidas de que seremos vencedores, até porque, do Cabula a Ayotzinapa, do Jardim São Luís a El Alto, na Bolívia, do Santa Marta a Cuartel Quinto, na Argentina, escorre pelo chão o mesmo sangue que vibra resistência nas veias abertas dessa nossa América Latina.

- Helena Silvestre, ativista da região sul

Era 30 de maio de 2015. Dia frio na zona sul. Uma grande tenda havia sido montada na área livre do cemitério São Luís. E ali, onde é enterrada a maior parte das vítimas de homicídio da zona sul, realizou-se a primeira audiência pública da região para se discutir e reivindicar do poder público ações contra o chamado "genocídio dos jovens negros, pobres e periféricos”. Essa audiência foi fruto da reivindicação de ativistas locais que buscavam do governo municipal um posicionamento mais efetivo frente ao aumento das chacinas no início de 2015, cujas vítimas eram majoritariamente jovens do sexo masculino, sobretudo porque o 
município executava ali, há mais de dois anos, o Juventude Viva, plano que tinha por objetivo a "prevenção" de homicídio de jovens negros e pobres da periferia.

O público era de cerca de 300 pessoas, formado majoritariamente por ativistas locais, movimentos sociais, torcidas organizadas e familiares de jovens vítimas de homicídios. Contou também com representantes do governo municipal: o prefeito Fernando Haddad e o Secretário de Direitos Humanos, na época, Eduardo Suplicy.

A organização das falas, assim como a composição das mesas, foi planejada de modo que as vozes prioritárias fossem as de ativistas locais e as das famílias das vítimas, afirmou Marcio, do Comitê Juventude e Resistência. O Comitê e a Comissão da Verdade e da Democracia "Mães de Maio"69 foram os responsáveis pela organização da audiência. "O prefeito estará lá para ouvir" e não para "fazer palanque", diziam os organizadores. Por essa razão, as autoridades sentaram-se na plenária, juntamente com o público.

O clima da audiência era de tensão. Dois meses antes, na região, uma sequência de chacinas resultaram na morte de mais de 20 pessoas, a esmagadora maioria jovens, do sexo masculino e negros. Cheguei a acompanhar essas ocorrências por mensagens via celular que recebia de amigos:

- "Três moleques assassinados agora na frente da minha casa, três moleques, meu Deus!";

- “Vivemos isso no final da década de 1980, morreu gente pra cacete, vocês lembram?”;

- "Aí, essa tarde mataram um cara ao lado da padaria do Monte Azul, dois caras numa moto passaram e atiraram";

- "Na segunda mataram um na Guarapiranga. Rolou manifestação depois e queimaram um ônibus";

- “Gente, não sei o que dizer dessa imensa dor e sofrimento que estamos passando, isso está acompanhado de medo e impotência. Vocês sabem o que está acontecendo?;

- "Tá complicado, em todas as quebradas o povo fala a mesma coisa, somos alvo e estamos com medo!"

Nos sentíamos paralisados, perdidos e impotentes. Poucas eram as possibilidades de ação: acompanhar o enterro, conversar com as famílias, buscar maneiras de proteger quem estava sendo ameaçado. Não se sabia ao certo quem eram os responsáveis, por isso não se sabia ao certo nem de quem se proteger. Embora os rumores, quase unânimes, recaissem

69 Instalada na Assembleia Legislativa do Estado de São Paulo (Alesp), a Comissão da Verdade e da Democracia "Mães de Maio" (CVDMM) tem por fim esclarecer casos de violações cometidas pelo Estado brasileiro no período posterior à ditadura militar. 
sobre a polícia militar ou sobre "pés de pato"70 e "grupos de extermínio" que, na opinião dos ativistas, a ela estavam relacionados.

E a quem recorrer? No que se refere aos órgãos públicos, nenhum caminho era seguro: denunciar à polícia, risco de morte; Judiciário, distante e inacessível; políticas sociais, nenhuma preparada para amparar as famílias que haviam acabado de perder seus entes; políticas de proteção, insuficientes e também distantes; movimentos e coletivos locais, frágeis e tão confusos quanto as próprias famílias frente à violência.

Essa "onda de violência" coincide então com o início da implementação do Plano Juventude Viva, no final de 2012. Trata-se de uma ação do governo federal executada pelo município de São Paulo, que tinha por fim a "prevenção" dos homicídios de jovens negros e pobres. Uma política frágil, que se propunha a "prevenir" homicídios em uma região onde familiares das vítimas de homicídio e ativistas estavam tomados por dor, medo, raiva, impotência. Este era o contexto da realização da audiência, que ocorria justamente no cemitério São Luís, lugar em que, conforme dito, sempre foram enterrados os jovens vítimas de violência na região, chegando, na década de 1990, a realizar de 800 a mil sepultamentos por mês, $90 \%$ resultados de mortes violentas ${ }^{71}$.

O dia 30 de maio de 2015 vai ficar marcado na história da zona sul da cidade de São Paulo. Foi quando se realizou, no cemitério do Jardim São Luís símbolo da morte de nossos jovens assassinados pela violência de Estado (que segue até hoje) nos tenebrosos anos da década de 1990 -, uma audiência pública contra o genocídio da juventude pobre, preta e periférica levado a cabo há 500 anos e hoje continuado pelas nossas polícias, que mantêm a estrutura de funcionamento da época de nossos lamentáveis anos de ditadura militar. (Helena Silvestre)

As falas durante a audiência oscilavam em pressionar também o município, e não apenas o governo do estado, para que as autoridades assumissem responsabilidades frente às mortes e criassem ações de reparação e apoio às vítimas e seus familiares. A tal demanda, os representantes do governo respondiam que estariam à disposição, embora houvesse limites, pois eles não teriam governabilidade sobre as ações do governo estadual. A animosidade contra o prefeito era explícita, embora houvesse também muitas falas de apoio à gestão municipal.

\footnotetext{
70 Conhecidos como "matadores de aluguel” ou "justiceiros”, que agiram muito na década de 1990, mas não deixaram de existir na região.

71 Cf. www.eca.usp.br/babel/antes/index3.php?tema=Espera\&id=17
} 
Mesmo com tensão, as pautas propostas pela organização da audiência, que estavam organizadas em uma carta, foram aprovadas e um termo de compromisso foi assinado, em que a prefeitura se comprometia, "por meio da Secretaria de Direitos Humanos, a atuar na pressão e na intermediação com o governo estadual sempre que houver alguma ocorrência de violência policial" ${ }^{72}$. Nesse termo, os ativistas denunciavam não apenas a fragilidade das ações municipais frente aos homicídios, mas também a reprodução da violência do Estado para além das mortes, tais como: impossibilidade de velar os mortos, como ocorrido no cemitério São Luís durante as últimas chacinas, em que os familiares tiveram apenas 15 minutos de velório; violência hospitalar; falta de acesso ao judiciário etc.

Essa audiência foi, na realidade, a culminância dos conflitos gerados no processo de implementação do Plano Juventude Viva, que envolveu a criação de um comitê intersetorial formado por representantes do governo e por lideranças locais. Nesse comitê, foram travados debates e propostas de ações que intensificaram as contradições e os limites das ações do Estado buscando minimizar a "violência perpetrada pelo próprio Estado".

O evento foi, assim, a publicização dos conflitos que aconteciam nas reuniões do comitê, sobretudo no que se refere à explicitação das contradições e dos limites de uma política frágil que buscava a "prevenção" de "homicídios de jovens, negros e pobres" frente a uma crescente militarização e violência policial.

Não busco, neste texto, apresentar o processo de constituição da política, nem as disputas em âmbitos mais amplos do Plano Juventude Viva, como o federal e o municipal. Tampouco procuro avaliar seus impactos ou resultados. Meu objetivo, neste trabalho, é refletir sobre o processo que pude acompanhar no cotidiano da zona sul e, novamente, tentar captar, nestas margens do Estado, as (re)produções de violência e ações de resistência. A tentativa de implementação, os conflitos do comitê, as lideranças e as instituições envolvidas, o recuo da implementação e o surgimento do Comitê Juventude e Resistência. Aqui, novamente, entendendo esses lugares como as "margens" do Estado.

\section{Juventude, uma categoria}

Há mais de dez anos tenho trabalhado em instituições ou me envolvido com grupos e movimentos sociais que se articulam em torno da categoria juventude. Esses segmentos não estão necessariamente ligados entre si, mas possuem, ou possuíam, no mínimo, alguma

\footnotetext{
72 http://ponte.org/movimentos-exigem-do-estado-medidas-contra-genocidio-na-periferia/
} 
conexão: pessoas, ideias, trabalhos conjuntos etc. Inicialmente, fui ativista do Mova Movimento de Alfabetização de Jovens e Adultos -, um programa municipal concebido durante a gestão de Paulo Freire na Secretaria de Educação Municipal, em 1989. Esta ação promovia a participação, com base em convênios entre governo municipal e instituições da sociedade civil, para o enfrentamento dos altos índices de analfabetismo na cidade. Em 1993, Paulo Maluf, ao assumir a prefeitura, acaba com esses convênios. No entanto, muitas instituições continuaram com o trabalho de alfabetização sem abrir mão do nome Mova, organizando, inclusive, um movimento municipal, o Fórum Mova. O Ceop - Centro de Educação e Organização Popular -, instituição comunitária situada na favela São Remo, zona oeste de São Paulo, engajou-se nesse movimento. Minha atuação no Ceop teve inicio em 2001, que coincidiu com o retorno do PT à gestão municipal, impulsionando também o retomada dos convênios depois de quase dez anos. Isso garantiu recursos e formações para as instituições.

O Mova da cidade de São Paulo estava articulado com movimentos de outras cidades pelo país. A partir da ascensão do PT ao governo federal em 2003, com Luís Inácio Lula da Silva na presidência, fortaleceu-se uma articulação nacional dos Movas por meio da promoção de diversos encontros nacionais. Foi quando comecei a ter contato com alguns atores importantes nesse campo, como é o caso da Ação Educativa ${ }^{73}$, organização de referência na produção de estudos e materiais pedagógicos em educação de jovens e adultos, em que passei a trabalhar, a partir de 2006, justamente por minha "experiência" no Mova.

$\mathrm{Na}$ Ação Educativa, comecei a trabalhar em um programa chamado Educação de Jovens e Adultos (EJA), que prestava assessorias às Secretarias Municipais e Estaduais de Educação no sentido de qualificar os professores de EJA, produzindo materiais didáticos e atuando em articulações nacionais em torno dessa questão. "Juventude" não era uma pauta específica na EJA. No entanto, começou a surgir uma interface entre a Educação de Jovens e Adultos e o "campo" da "Juventude" com o lançamento do Projovem em 2005, programa do governo federal que tinha por objetivo elevar a escolaridade de jovens entre 18 e 24 anos que não tivessem concluído o ensino fundamental, qualificando profissionalmente e propondo atividades comunitárias. Os participantes recebiam na época uma bolsa de R\$ 100 e concluíam o curso em dois anos. O programa foi reformulado em 2007, ampliando a idade dos participantes para 29 anos e mudando o nome para Projovem Urbano, já que outras

73 Cf. http://www.acaoeducativa.org.br/ 
modalidades de Projovem foram incorporadas à política: Projovem Rural ${ }^{74}$, Projovem Adolescente $^{75}$, Projovem Trabalhador ${ }^{76}$, os quais possuíam atividades, recursos e gestões distintas.

A Ação Educativa foi uma protagonista importante nas políticas de juventude, sobretudo pelo acúmulo nas áreas de EJA e Juventude, exercendo grande influência na elaboração das políticas sociais em âmbito federal. Não só o Projovem Urbano contou com a colaboração institucional, como também a ideia de que a juventude é uma fase de vida que demanda políticas específicas foi fortalecida pela "Ação". A instituição realizou seminários e publicações reunindo pesquisadores, movimentos sociais e partidos políticos, acompanhou a constituição do Conjuve - Conselho Nacional de Juventude -, entre outras ações. Foi lá que comecei a ter contato com ideias como: juventude enquanto "sujeito de direitos", autonomia, emancipação, participação, “juventudes”, dentre outras que envolvem, hoje, a política nacional de juventude.

A partir das relações que estabeleci na Ação Educativa, e por conta de minha "experiência em juventude", fui indicada a assumir o cargo de gestora da política de juventude no município de Embu das Artes, na grande São Paulo. Lá, me deparei com um quadro completamente diferente do que via na Ação Educativa e nos debates que ocorriam em nível federal. A cidade já era reconhecida por um "relativo avanço" no que se refere à implementação de uma política específica para a juventude tendo em vista não apenas a execução das políticas setoriais focadas em juventude, mas também o desenvolvimento do "protagonismo" juvenil e da participação política. Além disso, existia o esforço em "transversalizar" a política para o restante do governo, com a finalidade de "construir" a ideia de juventude não só como um segmento da população com "necessidades específicas", mas também como protagonista da política que deveria ter representação em espaços de gestão democrática, sobretudo nos conselhos.

Na prática, essa tarefa tinha seus limites, não só pela disputa da execução da própria política de juventude, alocada na Secretaria de Participação Cidadã, mas sobretudo pelas divergências sobre os sentidos e valores que deveria assumir essa política no interior do governo. Declaradamente, existia um conflito entre setores da Secretaria de Participação Cidadã, da Secretaria de Assistência Social e parte da Secretaria da Saúde acerca de práticas,

\footnotetext{
74 Possuía o mesmo formato do Projovem Urbano, mas buscava atender as especificidades dos jovens no campo.

75 Projovem Adolescente é uma política de assistência social que visa a "inclusão" de jovens entre 15 e 18 anos. É gerido pelo Ministério do Desenvolvimento Social.

76 Política de qualificação profissional e inserção no mercado de trabalho voltada para jovens entre 18 e 29 anos, gerida pelo Ministério do Trabalho e Emprego
} 
discursos e procedimentos que deveriam orientar o Estado no tratamento de adolescentes e jovens. Essa experiência no interior de um governo municipal de médio porte me proporcionou uma aproximação à dinâmica do Estado: a separação entre as secretarias, os interesses e os conflitos políticos, as burocracias, as hierarquias, as políticas sociais e as possibilidades de criação e flexibilidade.

Finalmente, então, aterrissei na zona sul, de início no "Fundão" do Ângela. Mas foi no CDHEP que pude ter um contato maior com a dinâmica política local envolvendo Estado e ativistas. Lá, a categoria juventude não era mobilizada pelo governo ou por profissionais das políticas sociais. Ela estava no discurso de ativistas, nos seus coletivos juvenis e ações culturais. A política de juventude, com o Plano Juventude Viva, chegou apenas posteriormente. Os profissionais das políticas sociais, apesar de usarem a categoria jovem, tinham práticas muito mais relacionadas à ideia de proteção do ECA e às políticas de assistência social do que aos princípios das políticas de juventude. Tanto que os termos "menino" e "menina" eram comuns no vocabulário dos profissionais ao se referirem aos adolescentes.

Mas todos esses usos da categoria "juventude" estavam ligados a uma noção de reivindicação de sujeitos de direitos e de construção de identidades a partir da especificidade dessa fase da vida. A categoria juventude encontra-se nessa interface com o Estado, sendo as políticas sociais não só produto de reivindicações, como elas mesmas produtoras de articulações e movimentos sociais. Um conjunto dessas políticas estão presentes na periferia e contribuem para a ideia de juventude como uma categoria em torno da qual identidades e coletivos se constituem. São elas: Prouni ${ }^{77}$, Fies $^{78}$, Pronatec ${ }^{79}$, Juventude Viva, VAI ${ }^{80}$, Pontos de Cultura ${ }^{81}$, Projovem, Fábrica de Cultura ${ }^{82}$ etc. Finalmente estava na "ponta do serviço",

77 O Programa Universidade para Todos (Prouni), do Ministério da Educação, criado pelo governo federal em 2004, oferece bolsas de estudos, integrais e parciais (50\%), em instituições particulares de educação superior, em cursos de graduação e sequenciais de formação específica, a estudantes brasileiros sem diploma de nível superior que tenham estudado em escolas públicas ou em escolas particulares como bolsistas.

78 Programa do governo federal, criado em 1999 e reformulado em 2010 para substituir o Programa de Crédito Educativo (PCE/Creduc), que financia a graduação no Ensino Superior de estudantes que não possuem condições de arcar com os custos de sua formação

79 O Programa Nacional de Acesso ao Ensino Técnico e Emprego (Pronatec) foi criado pelo governo federal em 2011 com o objetivo de oferecer cursos de educação profissional e tecnológica para jovens e beneficiários de programas de transferência de renda.

80 Ação do governo municipal, que subsidia projetos culturais de jovens ou voltados para a juventude de baixa renda

81 Pontos de Cultura são grupos, coletivos e entidades de natureza ou finalidade cultural que desenvolvem e articulam atividades culturais em suas comunidades e em redes, reconhecidos e certificados pelo Ministério da Cultura.

82 Equipamento de cultura do governo do estado de São Paulo gerido por instituições da sociedade civil 
expressão que usávamos nos âmbitos de articulação nacional ou de elaboração das políticas no governo federal.

Este trânsito entre o âmbito nacional de articulação e execução da política em nível federal, o âmbito municipal de implementação de uma política municipal e a observação do cotidiano da política, na "ponta" dos serviços, me proporcionou um olhar muito mais amplo sobre fluxos, contradições e limites dessas políticas. Por isso é que pretendo continuar detendo meu olhar no âmbito do cotidiano.

Juventude é uma categoria que, desde os anos 1990, vem se fortalecendo no Brasil, servindo de eixo em torno do qual movimentos sociais, instituições da sociedade civil e ações governamentais começaram a se articular. Segundo bibliografia sobre o tema, juventude se inscreve como questão social no mundo contemporâneo a partir de duas abordagens principais: como etapa problemática, marcada pela rebeldia, ou como fase de transição para vida adulta. Por um lado, haveria a via dos "problemas", comumente associados aos jovens delinquência, comportamento de risco, drogadição, entre outros -, que demandaria enfrentamento por parte do Estado. Por outro, haveria o entendimento de juventude como fase transitória para vida adulta, uma espécie de moratória social ou de um crédito de tempo concedido ao indivíduo, que protela sua entrada na vida adulta e possibilita experimentações que favorecerão seu desenvolvimento, sobretudo em termos de formação educacional e treinamento. Tal fase esta exigiria esforço coletivo, sobretudo por parte da família e da escola, a fim de preparar o jovem para ser um adulto socialmente ajustado e produtivo (Aquino, 2009; Castro, 2012; Sposito, 2008). Essa abordagem sugere uma transição demarcada por etapas que se sucedem na incorporação de papéis típicos do mundo adulto ao longo do tempo: estudante, trabalhador, chefe de família, pai/mãe. Ao fim desse processo, então, o jovem adentra o mundo adulto, cuja marca é a estabilidade. Sob este enfoque, os "problemas" do comportamento juvenil foram redefinidos, passando a ser compreendidos como desvios ou disfunções do processo de socialização.

Essa ideia de juventude parece estar expressa nas políticas, como tratado no capítulo anterior. "Jovens infratores" poderiam ser "reinseridos" no mundo social pelo processo de normatização: trabalho, educação e, por fim, a estabilidade de constituição de uma família.

Com o aumento demográfico de jovens, outro enfoque começa a compor os discursos sobre juventude, difundido sobretudo por organismos multilaterais e agências internacionais a partir da década de 1990, quando os sujeitos passam a ser vistos como atores estratégicos do desenvolvimento. No entanto, tal bônus demográfico tem sido ameaçado por outro fenômeno, o do desemprego, sobretudo a partir das décadas de 1980 e 1990, dificultando a entrada de 
grande parte dos jovens que saíram da escola no mercado de trabalho. Isso resulta num prolongamento da colocação profissional e da formação educacional de jovens, especialmente aqueles oriundos de famílias privilegiadas, implicando uma ampliação da moratória para alguns e a submissão de jovens de outras classes a empregos de baixa qualificação e remuneração:

Embora ganhe tonalidades diferentes segundo as possibilidades que o nível de renda familiar permite, o bloqueio à emancipação econômica dos jovens, em ambos os casos, além de frustrar suas expectativas de mobilidade social, posterga a ruptura com a identidade fundada no registro filho/a, adiando a conclusão da passagem para a vida adulta e ensejando uma tendência de prolongamento da juventude. (Aquino, 2009, p. 27)

Juntamente com a ideia de prolongamento da fase juvenil está a ideia de dessincronização das passagens. Novos padrões no exercício da sexualidade, da nupcialidade e a conformação dos diversos arranjos sociais, não apenas o formato de família nuclear, colocam em xeque a centralidade do mercado de trabalho como marco necessário e definitivo para a passagem à vida adulta, obscurecendo a noção de juventude enquanto fase transitória.

Com isso, o foco em um ponto de chegada que se projeta no futuro transferese para o momento presente, para a juventude em si, que ganha importância como etapa genuína do ciclo da vida. A mobilização social e política de jovens, que se consolida ao longo da década de 1990, tem papel decisivo na conformação deste novo contexto ideológico, em que emerge a compreensão dos jovens como sujeitos de direitos, definidos não mais "por suas incompletudes e desvios", mas por suas especificidades e necessidades, que passam a ser reconhecidas no espaço público como demandas cidadãs legítimas. (Aquino, 2009, p. 28.)

Assim, surge a noção de juventude como sujeito de direitos, juntamente com outras noções - "juventudes" -, tentando destacar a diversidade e os aspectos da desigualdade que fazem com que jovens passem por essa etapa de forma diversa. É sobre essas noções que se constituem as políticas de juventude:

Diante do desafio de inovar esta concepção, o Governo Federal passou a reconhecer que a juventude não é única, mas sim heterogênea, com características distintas que variam de acordo com aspectos sociais, culturais, econômicos e territoriais. Este novo olhar inaugurou uma nova concepção de política pública, que considera a juventude como um segmento social portador de direitos e protagonista do desenvolvimento nacional. (Guia da Juventude, 2006, p. 6) 
Vale ressaltar, ainda, a distinção defendida por vários autores (Corte e Souza, 2004; Abramo, 2009) entre juventude e adolescência, mesmo que essas categorias sejam normalmente empregadas como sinônimos. Para esses autores, juventude deve ser entendida como uma categoria social representada pelo vínculo entre os indivíduos de uma mesma geração formando um segmento social específico, enquanto adolescência traduziria um processo mais individual e subjetivo ligado às transformações físicas e psíquicas dos indivíduos (Corte e Souza, 2004, p. 12).

Esta discussão sobre a formulação do conceito de juventude e seus usos importa aqui porque elementos dessa concepção são articulados cotidianamente nos discursos de representantes do governo, profissionais das políticas sociais e ativistas de movimentos sociais que figuram em meu campo de pesquisa. Estes últimos, inclusive, mobilizam o conceito tendo em vista a denúncia do "genocídio da juventude negra, pobre e periférica". Na minha hipótese, há uma disputa de enquadramentos possíveis em torno da questão dos homicídios de jovens, muitas vezes justificados e legitimados pela ideia do "bandido" categoria que surge com a emergência do mundo do crime (Feltran, 2010), mas que também está ligada às ideias de delinquente, do menor ou do marginal que sustentaram, ao longo do século XX, as ações repressivas e punitivas do Estado voltadas para a infância e a adolescência pobre.

\section{A política de juventude}

No Brasil, as políticas sociais são definidas a partir de ações do Estado que visam atender aos direitos sociais e cobrir riscos ou contingências que estejam afetando condições básicas de vida da população (Castro, 2009). Para isso, dividem-se em dois tipos, de acordo com o objetivo: o de proteção social, que visa uma resposta direta a necessidades de indivíduos e grupos geradas pelo que se convencionou a chamar de situação de "vulnerabilidade"; e o de promoção social, que visa a geração e fruição da capacidade de indivíduos e grupos sociais. Tais ações se realizam a partir das políticas setoriais, de saúde, de educação, da cultura, de assistência social etc., bem como a partir das políticas transversais, que recentemente foram ganhando espaço na estrutura da políticas sociais no Brasil, sobretudo a partir da pressão dos movimentos sociais: de mulheres, LGBTT, criança e adolescência, raça, juventude etc. Essas políticas têm a função de definir diretrizes do governo 
frente a necessidades de segmentos populacionais específicos e garantir que tais necessidades e especificidades sejam consideradas na execução das políticas sociais (Reinach, 2013).

De acordo com essa lógica, então, a política de juventude tem a função de garantir que as especificidades e as necessidades de jovens sejam consideradas na formulação e na execução das políticas sociais setoriais. Legalmente, a juventude é definida pelo segmento populacional composto por pessoas de 15 a 29 anos (Lei 11.129/2005 ${ }^{83}$ ). A partir da década de 1990, o debate em torno do Estatuto da Criança e do Adolescente (ECA) e das discussões que surgiam sobre juventude, como sinalizado no item anterior, ampliaram a concepção de juventude para além da adolescência formalmente concebida entre 12 e 18 anos e que tinha como instrumento legal principal o ECA.

Enquanto a política de crianças e adolescentes tem como paradigma a proteção de crianças e adolescentes como "sujeitos de direitos" em desenvolvimento, a de juventude tem por fim destacar a autonomia, a diversidade desse segmento e a participação política, mas sempre reforçando a ideia de juventude como sujeitos de direitos. Segundo seus documentos normativos, dentre as maiores preocupações dessa política estão: demarcar as especificidades das necessidades de "jovens"; voltar-se para jovens com mais de 18 anos e problematizar a violência, a delinquência e o comportamento de risco como foco primordial das ações do Estado; promover a autonomia e a emancipação; e ressaltar o direito de participação política e social. Como marco legal, conta com o Estatuto da Juventude, promulgado pela Lei 12.852/2013, que considera jovens pessoas com idade entre 15 e 29 anos, com a ressalva de que aos adolescentes com idade entre 15 e 18 anos aplica-se o ECA e, excepcionalmente, o Estatuto da Juventude, quando este não conflita com as normas de proteção integral do adolescente. Dispõem sobre os princípios que devem reger as políticas de juventude:

Art. 20 $\mathrm{O}$ disposto nesta Lei e as políticas públicas de juventude são regidos pelos seguintes princípios:

I - promoção da autonomia e emancipação dos jovens;

II - valorização e promoção da participação social e política, de forma direta e por meio de suas representações;

III - promoção da criatividade e da participação no desenvolvimento do País;

83 Institui o Programa Nacional de Inclusão de Jovens - Projovem -; cria o Conselho Nacional da Juventude CNJ - e a Secretaria Nacional de Juventude; altera a Lei no 10.683, de 28 de maio de 2003, e a Lei no 10.429 , de 24 de abril de 2002; além de outras providências. 
IV - reconhecimento do jovem como sujeito de direitos universais, geracionais e singulares;

V - promoção do bem-estar, da experimentação e do desenvolvimento integral do jovem;

VI - respeito à identidade e à diversidade individual e coletiva da juventude;

VII - promoção da vida segura, da cultura da paz, da solidariedade e da não discriminação; e

VIII - valorização do diálogo e convívio do jovem com as demais gerações.

Desde 1997, no âmbito do governo federal, diversas ações voltadas para jovens começaram a surgir. Entretanto, é apenas em 2004 que se inicia um processo de consolidação de uma política de juventude, fortemente inspirada nos debates e compromissos internacionais (ONU, Organização Ibero-Americana de Juventude). Segundo Silva e Andrade (2009), tal política não se inspira nos desvios, mas sim na ideia de juventude como sujeito de direitos, definida por suas especificidades e necessidades e como estas devem ser reconhecidas no espaço público enquanto demandas cidadãs e legítimas. Tratam-se de políticas que ampliam a questão de enfrentamento dos problemas de vulnerabilidade social, buscando também oferecer oportunidades de experimentação e inserção social múltiplas que favoresçam a integração dos jovens nas várias esferas sociais.

A Secretaria Nacional de Juventude (SNJ), Vinculada à Secretaria-Geral da Presidência da República, de acordo com sua própria definiç̧ão, tem a tarefa de coordenar, integrar e articular as políticas de juventude, além de promover programas de cooperação com organismos nacionais e internacionais, públicos e privados, voltados para o segmento juvenil.

Entre um conjunto de programas e ações da SNJ, assume-se como principais: o Plano de Prevenção à Violência contra a Juventude Negra, denominado Juventude Viva, que visa prevenir a violência e combater sua banalização por meio de políticas de inclusão e ampliação de oportunidades para os jovens negros; o Programa Estação Juventude, que tem por objetivo promover a inclusão e a emancipação dos jovens, com a ampliação do acesso às políticas públicas por meio de equipamentos públicos; o Participatório, que se caracteriza como um espaço de produção do conhecimento e divulgação de conteúdos, focado nos temas ligados às políticas de juventude; e o Programa Juventude Rural, de Inclusão Produtiva, Formação Cidadã e Capacitação para Geração de Renda, para os jovens rurais e, em especial, 
populações ribeirinhas, indígenas e quilombolas; além do apoio ao fortalecimento institucional dos órgãos gestores estaduais e municipais de juventude ${ }^{84}$.

Neste trecho do capítulo, procurei trazer alguns elementos que compõem a política de juventude no cenário nacional: conceitos, diretrizes, estruturas, documentos normativos, leis e funcionamento. Seu foco na participação política e na autonomia dos jovens propõe enquadramentos diferentes daqueles das políticas que estão mais preocupadas com a normatização de adolescentes potencialmente "perigosos" ou a punição dos já considerados "perigosos", como tratado no capítulo anterior.

Nas margens do Estado, observamos os desdobramentos dessas políticas de juventude, e o interesse deste capítulo é focar em uma delas, o Plano Juventude Viva, mais especificamente, no processo de implementação desse Plano e os conflitos, sujeitos, discursos e instituições nele envolvidos.

\section{O Plano Juventude Viva na zona sul}

O lançamento do Plano Juventude Viva aconteceu em outubro de 2013 no CEU Casa Blanca. Teatro lotado, com a presença de lideranças e artistas locais, jovens "atendidos" em ONGs e equipamentos públicos, profissionais das políticas sociais e representantes do governo. No palco, a mesa era composta por Gilberto Carvalho, então chefe da SecretariaGeral da Presidência da República; Luiza Bairros, chefe da Secretaria de Políticas de Promoção da Igualdade Racial (Seppir); o prefeito Fernando Haddad; o secretário municipal de Promoção da Igualdade Racial, Netinho de Paula; o secretário de Direitos Humanos, Rogério Sotille; o então coordenador municipal de Juventude, Gabriel Medina; e Issac de Souza Faria, do Núcleo de Jovens Políticos do Jardim Ângela, ligado ao Partido dos Trabalhadores (PT).

Antes mesmo de começar a cerimônia, três jovens negros sobem repentinamente no palco e pegam o microfone de assalto "disparando poesias para todos os lados", como eles mesmos escreveram nas redes sociais posteriormente. Eram eles William, Pedro e Douglas, integrantes do coletivo Tamo Vivo, que realiza mensalmente o sarau "Preto no Branco", no Jardim Ibirapuera. "Juventude suicida, poesia salva a vida": com estes dizeres os três se revezavam nas rimas, tomando conta de todo o palco.

\footnotetext{
84 http://juventude.gov.br/
} 
Está quase na hora de partir Caminho com passos rápidos

Mas cautelosos, né?

Periferia, você sabe

Não se pode vacilar

A chuva fina que cai do céu

$\mathrm{O}$ vento frio que bate no meu rosto

Com eles vêem a notícia

Que já foram quatro mortos pela polícia

Uns dizem

Estava na hora errada, no lugar errado

Outros dizem

Foi o motoqueiro fantasma, mano

Mas a certeza é

Mais um nas estatísticas

Mais um arquivo fechado

Mais um preto morto

Nessa porra dessa ditadura

Nós aqui, ó

Somos apenas sobreviventes

Do campo de extermínio, tá ligado?

Não apenas a ousadia do ato, que desestabilizou os protocolos da solenidade que contava com autoridades do governo, mas também o conteúdo das poesias, que escancaravam a "realidade" e o sofrimento gerados pelos numerosos casos de homicídios, causaram um misto de euforia e desconforto. Principalmente porque foram declamadas por jovens que seriam considerados o "público-alvo" do plano. Esse episódio já explicitava as divergências de posicionamentos que acompanhariam todo o processo de implementação do Juventude Viva na zona sul. São conflitos que permanecem até hoje.

Com a polarização do conflito, haviam dois posicionamentos que mais se sobressaíam. Por um lado, representantes do governo municipal, junto a instituições e ativistas que os apoiavam e, consequentemente, viam a implementação do Plano sem maiores críticas. Por outro, discursos mais radicais, que constantemente confrontavam o governo, repletos de críticas e desconfianças com relação às ações da gestão municipal. Os primeiros estão mais alinhados a uma esperança de que a aproximação entre Estado e sociedade civil possa “transformar as políticas", readequando procedimentos técnicos, minimizando a precarização, enfim, ajustando as ações aos interesses e às necessidades da população. Os segundos são movidos pela crítica à violência do Estado, à ideia de que seus representantes agem por interesses vinculados à disputa de poder, sendo a população "negra e periférica" sempre "esquecida ou vitimizada". 
Obviamente, esses posicionamentos não estão tão consolidados assim, mas é possível perceber, em quase todas as reuniões em que participo na região, eles presentes. E não foi diferente na implementação do Juventude Viva.

O Plano Juventude Viva é uma iniciativa do governo federal, coordenada pela Secretaria Nacional de Juventude (SNJ) e pela Secretaria de Políticas de Promoção da Igualdade Racial (Seppir). O Plano tem por objetivo a "prevenção" de homicídios de jovens, negros e pobres. Para isso, busca desenvolver ações que reduzam a vulnerabilidade de "jovens negros" a situações de violência física e simbólica, a partir da criação de oportunidades de inclusão social e autonomia para os jovens entre 15 e 29 anos, conforme reza a sua cartilha.

As ações do Plano visam a ampliação dos direitos da juventude, a desconstrução da cultura de violência, a transformação de territórios atingidos por altos índices de homicídios e o enfrentamento ao racismo institucional, com sensibilização de agentes públicos para o problema85. Uma árdua tarefa, sobretudo uma vez confrontada com altas taxas de homicídio, criminalidade e encarceramento presentes na periferia, bem como quando observados os limites orçamentários da política e a sua fragilidade institucional frente às questões estruturais relacionadas aos homicídios de jovens, principalmente o racismo institucional, a violência policial e o mundo do crime. Na época, a coordenadoria municipal de juventude, responsável, entre outras ações, pela execução do plano, contava com uma equipe de menos de dez pessoas, não exclusivamente dedicadas do Plano Juventude Viva.

No entanto, meu interesse, neste capítulo, não é o de discutir sobre a eficácia ou não do programa, mas sim o de trazer à tona os conflitos, discursos e desdobramentos de seu processo de implementação, na aposta de que, durante seu desenvolvimento, tenham emergido as contradições das ações do Estado, bem como as possibilidades de resistências.

O Juventude Viva é executado pela Secretaria Municipal de Direitos Humanos, por meio da coordenadoria de juventude. No município o Plano assume como ações prioritárias: o apoio financeiro à projetos da sociedade civil via convênios, a articulação dos serviços públicos já existentes e campanhas que busquem incidir sobre as altas taxas de homicídio de jovens na cidade.

As subprefeituras do Campo Limpo e M'Boi, que compreendem os distritos Capão Redondo, Campo Limpo, Jardim São Luís, Jardim Ângela e Vila Andrade, foram escolhidas para a implementação piloto no município devido às altas taxas de homicídio. Tal implementação implicou a constituição de um comitê gestor local intersetorial, isto é, um

85 Cf. http://juventude.gov.br/juventudeviva/o-plano\#.Vcl-YOWYQfo 
grupo formado por representantes da sociedade civil, da coordenadoria de juventude e das políticas sociais locais que acompanhariam o processo.

A primeira vez em que tive contato com o Plano foi em uma reunião organizada por ativistas da região, no final de 2012, que visava reunir instituições e lideranças que tivessem interesse em compor o segmento da sociedade civil no comitê. Já nesta reunião posições contrárias emergiam. Algumas pessoas mantinham certa desconfiança frente à eficácia dessa política. Outras acreditavam que ocupar tal espaço, entendido naquele momento como de "gestão democrática" de uma política, faria a diferença em sua execução. Essas posições só viriam a se intensificar e polarizar ainda mais ao longo do processo de implementação.

As reuniões do segmento da sociedade civil eram intercaladas com as gerais do Comitê Juventude Viva, em que representantes da coordenadoria de juventude e das políticas sociais locais também estavam presentes. As expectativas, sobretudo por parte de ativistas, era a de que o processo seria de construção coletiva e de planejamento conjunto com relação ao orçamento e às ações.

Mas, conforme as propostas do plano eram apresentadas, ficava cada vez mais explícito que as ações já tinham sido planejadas pelos gestores do Plano, ficando para o comitê um papel secundário de acompanhamento e monitoramento do plano.

Quatro ações me pareciam prioritárias e objeto de disputa no comitê. Eram elas: articulação das políticas sociais presentes no território; serviços de reparação psicossocial para vítimas de violência (que, até o final da escrita desta dissertação, não havia sido implementada); contratação de articuladores locais (dois por território); e disponibilização de editais que subsidiariam projetos propostos pela sociedade civil que buscassem prevenir a mortalidade. Além disso, o plano dispunha de orçamento para campanhas contra a mortalidade do Juventude Viva.

Com um planejamento já elaborado pela coordenadoria de juventude e recursos já "empenhados" para cada ação, as possibilidades de intervenção do comitê eram de fato muito limitadas. Além disso, a coordenadoria de juventude apresentava todas as ações de outras secretarias voltadas para a juventude como se fossem do Plano. As ações da educação, cultura, assistência social, esporte não estavam sendo capazes de interferir nas taxas de homicídio. Pelo contrário, ativistas denunciavam a reprodução da violência e do racismo institucional também nesses equipamentos, como tratado no capítulo anterior: 
Eles colocaram como Plano o processo que já existia nas pastas. Por exemplo, o VAI. Mas, espera aí, o VAI já existe, meu amigo! Iluminação, a iluminação já é da Secretaria de Serviços. Lembra da audiência aqui no CDHEP? Aqui na audiência a gente desmascarou o Plano. Porque esse comitê sempre pautou a transparência do orçamento e a origem do Plano. O que é esse Plano? Onde é o Plano? E eles não conseguiram explicar aqui o que era o Plano. (Fernando, ex-integrante do Comitê Juventude Viva, atualmente participa do Comitê Juventude e Resistência)

O segmento da sociedade civil do comitê reivindicou uma audiência pública para esclarecimento sobre o orçamento e sobre as ações de outras secretarias voltadas para a juventude, realizada em 15 março de 2014. Lideranças locais - tanto jovens, quanto não jovens - e profissionais das políticas sociais estiveram presentes. Foi quando tais questões ficaram mais dramáticas, pois foram feitas diversas denúncias às políticas sociais locais. E o público reivindicava mudanças estruturais: não somente a efetivação de direitos, mas também o enfrentamento às mortes.

O desconforto do coordenador de juventude e de sua equipe era visível -desconforto este que acompanhou todas as reuniões posteriores do comitê. O conflito era polarizado entre os ativistas da sociedade civil e os representantes da coordenadoria de juventude. Os profissionais das políticas sociais pouco se colocavam nas discussões.

Era também explícita uma incompatibilidade de interesses. Por um lado, a coordenadoria de juventude tinha "pressa" em dar prosseguimento às ações do governo. Para isso, necessitava de respostas rápidas do comitê, que ainda não compreendia completamente o Plano. Em uma das reuniões, a coordenadoria de juventude trouxe um grande mapa da região para que o comitê pudesse identificar locais que necessitavam de iluminação pública, pois "lugares escuros seriam lugares mais perigosos". Em meio à grande tensão e à "pouca produtividade" da reunião, um dos ativistas da sociedade civil se exaltou, batendo bruscamente no mapa afirmando que o "perigo na quebrada é a polícia e não os lugares escuros".

Por meio da ideia de "prevenção" dos homicídios, o Juventude Viva de certa maneira reforçava a responsabilização dos sujeitos, de suas famílias e do território pela violência. Lugares perigosos deveriam ser iluminados e jovens e suas famílias em situação de vulnerabilidade deveriam ser supervisionados e tutelados pelo Estado. Propunha a articulação dos serviços públicos em torno da questão, sem problematizar suas práticas e seus discursos, no que se refere à estigmatização do "público atendido", nem seus procedimentos "punitivos". Além disso, a violência do Estado não era colocada como pauta, tampouco qualquer outro 
compromisso do município ou do governo federal frente às políticas de segurança e ao papel da polícia militar na periferia.

As contradições do Plano emergiam em conflitos que eram ainda mais acentuados por diferenças raciais e sociais entre os representantes do governo e os ativistas locais. A equipe da coordenadoria da juventude era composta por pessoas brancas e, aparentemente, de classes mais privilegiadas, o que gerava desconfianças e rumores, uma tensão permanente. Tal tensão veio a ser minimizada quando Claudinho, jovem negro morador da "quebrada", assumiu a coordenação de juventude. A relação entre ativistas e coordenadoria se modificou: "agora a gente fala com os nossos". No entanto, não demorou muito para que as divergências e os interesses políticos novamente viessem à tona, ainda que a "cumplicidade" pelo fato de o coordenador ser negro e da "quebrada" sempre garantisse maior possibilidade de interlocução.

De acordo com Fernando, no começo as "coisas mudaram”, pois esse coordenador esteve mais ao lado das reivindicações dos ativistas locais e começou a dar mais apoio às ações. No entanto, em momentos em que era preciso "pressionar o Estado", o coordenador colocava seu limite. A audiência pública no cemitério São Luís foi um desses momentos, cujas reivindicações dos ativistas de não priorizar a fala do prefeito e não seguir os protocolos de cerimoniais oficiais causaram novamente um desgaste entre o Comitê e a coordenação de juventude.

Os profissionais das políticas sociais que participavam das reuniões não se expunham abertamente nos conflitos. Embora alguns compartilhassem dos posicionamentos dos ativistas da sociedade civil, eles "não poderiam se expor muito", pois também eram governo e poderia haver algum "problema caso falassem demais". No entanto, alguns ativistas da sociedade civil também não concordavam com a radicalidade dos "mais barulhentos". Não obstante, era a polarização do conflito que dava o tom das reuniões.

O que observo neste processo é mais uma vez o Estado tentando se impor hierarquicamente no território. E, diferente das políticas de assistência social e das medidas socioeducativas, que tendem a uma maior normatização e controle de adolescentes, os princípios que orientam as políticas de Juventude estão pautados em uma ideia de mais "participação" e "autonomia" dos sujeitos. Talvez seja por essa razão que a implementação do Plano tenha sido proposta numa perspectiva aparentemente mais "democrática", por meio da criação do Comitê Intersetorial. No entanto, na prática, observou-se uma incerteza acerca do papel deste comitê, justamente porque todas as ações previstas pelo Plano já estariam definidas e seus orçamentos ajustados. 
Além disso, outro aspecto que deve ser ressaltado é a fragilidade do Plano. Diferente de muitas políticas sociais, o Juventude Viva é uma ação governamental amplamente divulgada como uma ação efetiva para lidar com o grande problema social que é a mortalidade de jovens. No entanto, quando se observa a sua execução, nota-se que as propostas vão se dissolvendo conforme se chega às "pontas" dos serviços. Dessa forma, sem equipe, recursos ou equipamentos que significassem uma presença efetiva na região, o Plano não foi capaz nem de sensibilizar as políticas sociais municipais já existentes em torno da questão dos homicídios, uma de suas principais propostas.

Pouco se evoluiu com relação às ações previstas. Alguns editais foram abertos para a sociedade civil e articuladores locais foram contratados. As chacinas continuavam ocorrendo. Os ativistas permaneciam atônitos e impotentes a cada notícia, a cada nova demanda das famílias das vítimas ou de instituições. Em uma das reuniões em que se discutia a criação de uma rede de proteção por parte da sociedade civil, falava-se sobre uma dessas chacinas. Tratava-se da morte de três jovens em frente à casa de um dos ativistas do Comitê Juventude Viva. Havia um quarto jovem, que conseguira fugir e estava precisando de ajuda para sair da região, pois corria risco de vida. Uma das representantes da secretaria de juventude, com uma verdadeira boa vontade, disse que quando ficou sabendo a respeito "ligou para um amigo que era assistente social para ver no que ele poderia ajudar":

Quando eu e os demais presentes na reunião ouvimos aquela fala, tivemos a consciência do total despreparo e, talvez, desinteresse, tanto da Secretaria de Direitos Humanos quanto do Plano Juventude Viva, em consolidar políticas efetivas de enfrentamento dos casos de homicídio de jovens na região. Outra manifestação dessas foi a do então secretário de direitos humanos Eduardo Suplicy que, também em uma manifestação de solidariedade, deu R $\$ 200$ para a irmã de uma das vítimas das chacinas de 2015. (trecho do diário de campo)

Tais atitudes de representantes do governo frente ao desespero e à dor de familiares e ativistas foi despertando cada vez mais desconfiança e distanciamento destes com relação à Secretaria Municipal de Direitos Humanos, além de expressar a total ausência de mecanismos institucionalizados aos quais recorrer em caso de necessidade de proteção e denúncia, reforçando, assim, a tendência muito mais à violência do que à efetivação de direitos por parte do Estado.

No entanto, pretendo aqui observar os efeitos da implementação do Plano que não estavam necessariamente previstos. Um desses efeitos, talvez o mais evidente para os 
envolvidos, foi o fato de ele ter impulsionado alguns sujeitos para uma articulação em torno da temática juventude, mais especificamente em torno da questão dos homicídios de jovens. Como afirma Fernando:

Tudo começou com a vinda do Juventude Viva para o território. Porque foi a partir do JV que nós resolvemos se encontrar. O Juventude Viva veio como uma desculpa para nós, para voltarmos a discutir juventude. Estávamos isolados, cada um fazendo o seu. Criamos o primeiro comitê da sociedade civil Juventude Vive [formado apenas pelo segmento da sociedade civil do comitê para diferenciar do Juventude Viva]. E depois rompemos com o Juventude Viva e construímos o Comitê Juventude e Resistência, nos libertando das pautas do Estado. (Fernando, ex-integrante do Comitê Juventude Viva, integrante do Comitê Juventude e Resistência)

O Comitê Juventude Viva teve uma atuação de mais de três anos. Durante esse período, houve uma significativa aproximação entre ativistas e equipamentos públicos locais, que rendeu diversas atividades voltadas para os moradores, envolvendo a discussão sobre o homicídio de jovens e fortalecendo um discurso sobre "violência do Estado" e "genocídio da juventude negra e pobre" na região:

\begin{abstract}
Uma intensa atuação no território tendo em vista ampliar o discurso sobre a desnaturalização do racismo em todas as suas formas, sobretudo o homicídio. No entanto, durante todo o processo, os representantes da sociedade civil começaram a perceber que a gestão do plano junto à secretaria de direitos humanos e coordenação de políticas para juventude pouco apoio oferecia para a realização destas atividades. Na prática, elas foram realizadas pela sociedade civil com apoio de alguns gestores locais, acirrando posicionamentos entre governo e sociedade civil. (Bhering e Silva, 2010, p. 16)
\end{abstract}

De acordo com a avaliação dos ativistas integrantes do Comitê, os representantes da coordenadoria de juventude foram ficando cada vez mais distantes das atividades que ocorriam na região, tanto junto a equipamentos e serviços públicos, quanto também a partir da ampliação da articulação que os ativistas foram estabelecendo com outros movimentos e coletivos da cidade e do país: Mães de Maio; Quilombaque, na zona norte; Amparar, na zona leste; Terça Afro, na Noroeste; o Comitê contra o Genocídio Reaja, ou Será Morto, na Bahia; Mães que Lutam, no Rio. Segundo os ativistas, este "amadurecimento da luta" permitiu um fortalecimento da crítica ao racismo do Estado e seus mecanismos. Vejamos essa fala:

Fiquei muito feliz por ter entrado no processo do Plano [Juventude Viva], mas também me iludi muito. Talvez por eu ser novato de luta e conhecer 
pouco sobre essa luta do racismo institucional. Conhecer pouco também do genocídio de nosso povo de uma maneira elaborada. Mas era perceptível, no Juventude Viva, como eles viam os jovens como problema, e daí trabalhar com oficinas e atividades para controlar o problema. Isso nada mais é do que o fortalecimento da supremacia branca. Porque a partir desse controle do jovem que o Juventude Viva faz é para você proporcionar o bem-estar social na sociedade onde as pessoas que dominam os espaços e que têm dinheiro possam viver com menos crime e menos violência. Era notável. O Juventude Viva vinha a fortalecer a população branca, a elite. E não a população preta. E fui percebendo isso ao longo do processo. O quanto as pessoas que estão na coordenação de juventude, de direitos humanos e outras secretarias estão preocupadas com a manutenção do poder. Estão preocupadas com o partido. Elas estão preocupadas com estrelismo, consigo mesmas e com seus coletivos. Fazendo política pública de bancada. E a gente foi percebendo isso aos poucos. Eles diziam que estavam preocupados com a luta antirracista, mas queriam o controle da juventude negra, até de nós do comitê. (Vitor, ex-integrante do Comitê Juventude Viva, integrante do Comitê Juventude e Resistência)

Além da fragilidade do Plano, a implementação do Juventude Viva também deixara expostos interesses partidários de grupos e pessoas envolvidas no processo. Tais tipos de interesse são desprezados pelos ativistas que, hoje, se organizam em torno de coletivos e "lutam" numa perspectiva desvinculada de partidos políticos, intensificando ainda mais os conflitos.

Assim, depois de três anos de existência do Comitê Juventude Viva, um grupo de ativistas locais rompe, criando o Comitê Juventude e Resistência. Marcio Bhering e Vitor Silva, ambos participantes do Juventude Viva, escreveram posteriormente um artigo para uma revista produzida pelo CDHEP sobre o processo do Plano e a posterior criação do Comitê Juventude e Resistência.

Depois de uma avaliação na qual percebemos que o território não precisa de um plano que trate as pessoas como possíveis eleitores de uma gestão preocupada com a manutenção do poder, percebemos que não precisávamos do poder público para viabilizar nada, que já tínhamos construído muito. Decidimos então mudar a parceria com PJV, abandonar o comitê da sociedade civil e montarmos o comitê Juventude e Resistência, que nasce para combater o racismo institucional, fortalecendo os direitos da juventude negra, indígena, pobre e periférica com iniciativas voltadas para trabalhos em rede tentando minimamente dar visibilidade ao genocídio da juventude negra e às causas e consequências de um projeto histórico que visa exterminar o povo negro e indígena da dita nação brasileira. (Bhering e Silva, 2016, p. 40) 
O Plano Juventude Viva, apesar de tentar se impor de maneira vertical como outras ações do Estado, talvez por sua fragilidade institucional, talvez por seus princípios mais democráticos, favoreceu a eclosão de diversos conflitos em seu processo de implementação. São conflitos que, por um lado, expuseram as débeis políticas que buscam enfrentar a violência do Estado - a qual, por sua vez, é cada vez mais pungente. Por outro lado, gestaram a formação de ativistas que tiveram o Plano Juventude Viva e o Comitê como uma alavanca para a construção e o fortalecimento de luta contra a "violência do Estado", "contra o racismo" e contra "o genocídio de jovens negros da periferia". Assim, nasce o Comitê Juventude e Resistência.

\section{O Comitê Juventude e Resistência e a luta contra o genocídio de jovens negros e pobres da periferia”}

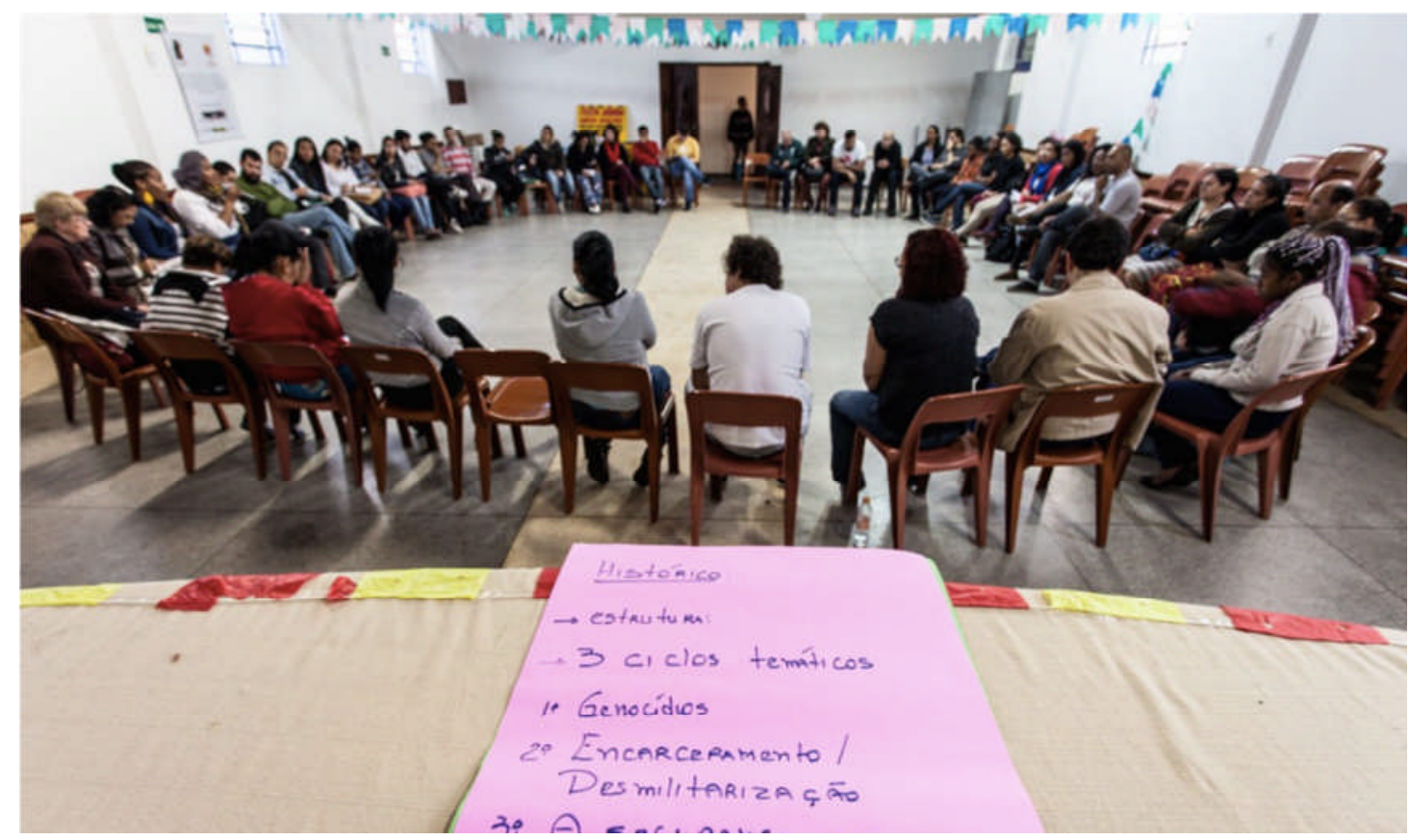

Foto: Wladimir Raeder/Democratize

Vitor tem 21 anos. Nasceu em Embu das Artes, no bairro Santa Tereza. Seus pais, como a grande maioria dos moradores da região, são migrantes. Vieram do Ceará no final dos anos 1980, buscando melhores condições de vida. Vitor começou a trabalhar cedo, aos 12 anos de idade, como ajudante de pedreiro, depois entregador de panfleto e pacoteiro de supermercado. Empregos mal remunerados que caracterizam a inserção precária no mercado de trabalho vivida por grande parte de jovens pobres. E, assim, intercalando horas de estudo 
com trabalho, Vitor completou o ensino fundamental na rede municipal de educação em Embu. Já o ensino médio concluiu no colégio particular São Luís, na av. Paulista, por meio de um projeto que a instituição oferecia para estudantes da periferia da cidade no período noturno. Vitor reconhece que teve acesso a um ensino de melhor qualidade se comparado às escolas estaduais. No entanto, ressalta que vivia no São Luís um contexto "cheio de racismo e preconceito, além de valores judaico-cristãos que interferiam no relacionamento entre os jovens", o que pôde elaborar somente depois de seu envolvimento com as "lutas".

Em 2012, entrou na UFRJ (Universidade Federal do Rio de Janeiro), no curso ciências sociais, a partir de sua nota no Enem ${ }^{86}$, o que atribui a ter estudado no colégio São Luís. Nesta universidade, conviveu com outros estudantes negros e pobres com quem começou a construir sua "identidade racial". Em 2013 prestou transferência para a USP, onde está concluindo a graduação. Vitor avalia que voltar para São Paulo, por um lado, representou a possibilidade de se envolver em "lutas" de coletivos e movimentos da periferia, mas, por outro lado, a experiência na universidade tornou-se muito mais "branca e elitizada" do que no Rio de Janeiro, fazendo com que sua atuação política se desse fora de seus "muros ".

Foi então que se aproximou do Plano Juventude Viva, sendo contratado como articulador local. Assim, apesar de todas as contradições do Plano, participar do processo proporcionou a aproximação de várias experiências de coletivos e organizações da cidade inteira. E, a partir daí, começou a perceber o que queria fazer. Vejamos as suas palavras:

Comecei a fazer a luta, né, que é muito mais que militância, pois sou sobrevivente dessa estrutura racista que mata milhões dos nossos no mundo inteiro, mas no Brasil é demais. Comecei a partir destas experiências com meus iguais, comecei me percebendo. Várias pessoas diziam que eu não era nada de pardo, eu era negro. Mas também a experiência de morar no Rio de Janeiro me fez refletir muitas coisas, pois eu morava na zona norte, região de favelas. Daí eu via ali o quanto que aquilo ali não era diferente do que acontecia em São Paulo, na Bahia e outros lugares do Brasil, o genocídio do povo preto, povo indígena. Daí comecei a pensar várias coisas, ainda não tinha nada de muito definido na cabeça, mas foi muito bom como experiência de vida. (Vitor)

A trajetória de Vitor é semelhante a de quase todos os ativistas com quem me relacionei ao longo destes anos. Seu acesso à universidade pública é um pouco diferente da maioria, embora não seja exclusivo. Trabalho precário, formação em escola pública, atuação

86 Exame Nacional de Ensino Médio, que permite que estudantes entrem em algumas universidades públicas sem prestar vestibular, contando apenas com a nota do Enem. 
política se misturam na constituição desses sujeitos. Mas o que chama a atenção aqui é novamente o processo de construção de identidade, sobretudo racial, mas também de sujeito periférico (D'Andrea, 2013), como elemento fundamental para o reconhecimento de si, do outro, e da possibilidade do engajamento em "lutas sociais".

A partir dessa construção de uma identidade racial e periférica, começa-se a forjar uma ideia do "nós" que fundamenta os discursos contra o "genocídio da juventude negra, indígena, pobre e periférica". Os termos que compõem a expressão dessa "luta" ainda estão em disputa: genocídio ou extermínio; juventude ou população; e a discussão sobre a inclusão ou não do termo "indígena”. No entanto, o que esta expressão visa é expor o problema social das altas taxas de mortes de jovens moradores da periferia, predominantemente negros, como um genocídio, isto é, a eliminação da existência física de um grupo racial protagonizada pelo Estado.

Aqui não pretendo me aprofundar na discussão sobre tal fenômeno. O que é importante registrar é como a maior parte de coletivos e ativistas da região vêm se articulando em torno dessa "luta", sobretudo a partir da experiência concreta vivida e/ou observada de violência policial. Além disso, a construção de uma identidade racial e "periférica" permite um reconhecimento de um "nós" submetido à violência do Estado. E é contra essa violência institucionalizada que este "nós" deve se proteger. Daí a desconfiança de tudo o que a ele esteja relacionado: partidos, instituições, serviços públicos. Forja-se, assim, a ideia de "nós por nós", como se não adiantasse mais nada recorrer ao Estado.

O Comitê Juventude e Resistência é forjado, então, nesse contexto. Formado por cerca de 15 pessoas, organiza-se da mesma maneira que muitos outros coletivos da região: estabelecendo relações horizontais entre seus membros, articulando-se autonomamente em relação à qualquer instituição ou partido político e não sendo institucionalizado, isto é, não possuindo um CNPJ (Cadastro Nacional de Pessoa Jurídica). Apesar do nome "juventude", nem todos os seus membros são jovens conforme os limites etários estabelecidos pelo governo federal, entre 15 e 29 anos. A maioria dos integrantes está na faixa dos 30 anos, embora tenham pessoas mais jovens e mais velhas.

Esse comitê está ligado a muitos outros coletivos existentes na região - inclusive, alguns são membros ou participam de outros movimentos ou instituições. Maria Edjane faz parte também do Núcleo de Mulheres negras ${ }^{87}$; Fernando Ferrari, do Movimento de Fomento

87 Núcleo formado exclusivamente por mulheres negras que tem por fim o "autocuidado" e o fortalecimento dessas mulheres 
às Periferias ${ }^{88}$; Sulamita, assim como Elaine, trabalham no MSE Capão II; Márcio faz parte da Comunidade Samba da Vila ${ }^{89}$; Andrea é atuante no Fórum em Defesa da Vida e professora universitária, entre outras pessoas.

Esta rede tecida por meio dos ativistas vai permitindo a circulação e a produção de discursos entre diferentes pontos. Não constituída a partir de documentos normativos ou de projetos de alguma instituição, a rede se forma pela atuação do cotidiano dos sujeitos que constroem suas trajetórias de vida a partir do ativismo. É a partir deles que esses novos discursos acabam penetrando, mesmo que de forma tímida, em espaços constituídos a partir de outros princípios e práticas das políticas sociais, como escolas, serviços de medidas socioeducativas - como o caso de MSE Capão II -, abrigos etc. Esses princípios e práticas impostos verticalmente tendem a produzir a normatização e a punição, mesmo quando ligados aos direitos humanos.

O Comitê Juventude e Resistência vem se articulando com movimentos sociais e coletivos de outras regiões da cidade, como as Mães de Maio ${ }^{90}$, para denunciar a violência do Estado, sobretudo a ação da polícia militar. No entanto, sua atuação ainda é muito frágil frente a uma questão tão complexa e devastadora quanto o homicídio. Muitas vezes, frente aos casos reais, seus integrantes ainda continuam com poucas alternativas de ação, principalmente no que se refere à proteção de pessoas, segurança em situação de denúncias etc., uma vez que tais casos, tanto de mortes quanto de ameaças, são quase que exclusivamente provocados por policiais.

É exatamente pela natureza desse problema social que busca enfrentar - a violência do Estado - que o Comitê se mantém em permanente interface com ele. Além disso, seus integrantes são constantemente convidados a realizar alguma atividade em equipamentos públicos, como no caso do MSE Capão II, já mencionado no capítulo anterior, mas também na DRE Campo Limpo, com a qual estão elaborando uma cartilha sobre abordagem policial. Também estão na constituição de um Tribunal Popular para “julgar” o Estado pelos seus "crimes".

\footnotetext{
88 Movimento que se articula em torno na construção da Lei de Fomento às Periferias, que destinará recursos exclusivos para manifestações culturais periféricas.

89 Comunidade de Samba do Parque Regina, que realiza rodas semanalmente e compõe sambas autorais. Foi contemplado pelo VAI neste ano, permitindo à comunidade oferecer oficinas de samba para moradores.

90 O Movimento Independente de Mães de Maio é formado por mães e familiares das 564 vítimas da ação de retaliação da polícia aos ataques do PCC em 2006. Busca hoje não só justiça para esses crimes, mas também se constituiu em uma frente de luta contra a violência do Estado, inspirando diversos movimentos sociais atualmente.
} 
Contudo, essa relação com o Estado ainda suscita muitas dúvidas e discussões no grupo. Há um consenso de que "não se pode esperar nada do Estado e dos governos". No entanto, não se pode abrir mão dessa relação, seja para se proteger do Estado, seja para buscar o mínimo de direitos. Assim, a saída encontrada, neste momento, é a atuação nas "pontas dos serviços", a convite de profissionais que se identificam com as reivindicações desses ativistas.

Foi a partir da aproximação com as pontas que começou a se construir uma relação mais próxima entre o Comitê e alguns técnicos do MSE Capão II. Passaram a ser realizadas algumas reuniões com a participação de familiares, sobretudo mães e avós, dos jovens "atendidos" pelo serviço, o que permitiu também maior engajamento não apenas dos "técnicos" na "luta contra o genocídio dos jovens negros, pobres e periféricos", mas também dos jovens "atendidos" e de suas famílias, como eles mesmo avaliam.

Nas reuniões, comecei a observar não apenas a presença das pessoas que são "atendidas" nos serviços, mas também a sua participação. Existe uma preocupação em estimular e priorizar a fala dessas pessoas. Nos encontros, as pessoas sempre estão sentadas em círculo. Neste ponto, talvez seja oportuno ressaltar essa forma de organizar encontros, tamanha é a frequência da prática em reuniões entre ativistas ou mesmo profissionais das políticas sociais.

Em quase todas as reuniões de que participo junto a esses coletivos, as pessoas estão sempre sentadas em roda. E existe uma grande preocupação na organização desses círculos: ele deve ser preparado para que todas as pessoas possam se observar, além de muitas vezes existir um centro cuidadosamente preparado com objetos significativos para a reunião e os participantes. A ideia é a de que o círculo favoreça o diálogo, que a circulação da fala se dê de forma mais horizontal e minimize as diferenças hierárquicas de poder.

Essa forma de organização é inspirada nos princípios da educação popular de Paulo Freire, fortemente disseminada entre os movimentos populares da década de 1980. Além disso, foi reforçada pelas práticas restaurativas difundidas pelo CDHEP, cuja base é o "círculo".

Nessas reuniões, presenciei também um fenômeno bem distinto do comum silenciamento e desqualificação das pessoas "atendidas" pelas políticas. Justamente porque as falas dessas pessoas são tão valorizadas e estimuladas que elas acabam emergindo com toda a força em forma de depoimentos sobre as violências sofridas, cujos protagonistas são, sobretudo, agentes do Estado: polícia e "técnicos" das políticas sociais e do Judiciário.

Nas reuniões, ouvi dessas pessoas falas como: “eu não sabia que existiam pessoas assim, que quisessem proteger a gente [referindo-se aos ativistas]”; “aqui foi a primeira vez 
em que pude falar sobre as mortes dos meus filhos"; ou, ainda, "antes eu queria que a medida [socioeducativa] do meu filho acabasse logo, mas agora eu não quero mais, porque quero continuar participando dessas reuniões" 91 .

E uma das reuniões mais importantes envolvendo pessoas "atendidas" em serviços, ativistas e "técnicos" foi uma atividade realizada na Sociedade Santos Mártires, organizada pelo Fórum em Defesa da Vida, cujo objetivo era discutir sobre o "genocídio das juventudes negra, indígena, pobre e periférica”. Considero oportuno expor um trecho do meu caderno de campo sobre essa atividade:

Era uma manhã de sábado do mês de julho de 2016. Mais de 50 pessoas se reuniam no salão da Sociedade Santos Mártires para conversar sobre violência do Estado. Tratava-se de uma ação preparatória para o "Tribunal Popular pelo Fim do Genocídio das Juventudes Negras, Indígenas, Pobres e Periféricas”, que tem por fim “condenar” o Estado como responsável por este "genocídio". Dentre os participantes, estavam ativistas da região, representantes do governo e profissionais das políticas sociais locais. Os integrantes do Comitê Juventude e Resistência, os "técnicos" do MSE Capão II e as famílias convidadas por estes, juntos, contabilizavam mais que a maioria dos presentes. Isso porque o comitê e o MSE se organizaram para "ocupar” o espaço, buscando incorporar na "luta contra o genocídio" as famílias dos jovens atendidos pelo serviço, além de reforçar essa pauta junto ao Fórum em Defesa da Vida. De todas as reuniões em que participei na região, esta foi a primeira que contava com a presença e a fala dos "usuários" das políticas sociais.

As pessoas estavam sentadas em um grande círculo, que tomava toda o sala. Foi exibido um vídeo com entrevista de Débora, fundadora do Movimento Mães de Maio, para iniciar o debate. As falas se alternavam entre denúncias mais elaboradas dos ativistas e os relatos de episódios vividos pelas famílias, majoritariamente mães, irmãs e avós de jovens que estão cumprindo medida socioeducativa. São trajetórias marcadas por mortes, prisões, ameaças, espancamentos vividos pelas famílias, sendo sempre a polícia militar a protagonista. As falas das mães eram priorizadas. Assim, na ordem das inscrições das falas elas eram colocadas sempre na frente de ativistas ou técnicos.

Beth, 64 anos, teve dois filhos mortos, um pela polícia e outro em um assalto. Ainda não consegue falar sobre suas perdas em público, prefere nos chamar ao canto para falar depois da reunião, para desabafar. Hoje acompanha seu neto, que cumpre medida

91 Neste momento, um dos ativistas respondeu que seu filho não precisaria estar em medida socioeducativa para ela continuar no processo, pois ela já fazia parte da luta 
socioeducativa no SME Capão II. Já Sônia perdeu seu irmão nas chacinas de 2015. Um policial atirou nele pelas costas e até hoje não sabe como anda o processo. Marina é mãe de Gabriel, que cumpre medida socioeducativa. Atualmente o adolescente já voltou à escola e está trabalhando. Mas isso não o protegeu da violência policial. Recentemente, o jovem foi pego em um escadão perto de sua casa e, segundo sua mãe, só não foi morto porque ela chegou a tempo. Marina falou para os presentes que a polícia entrou na sua casa e ameaçou sua família. Hoje todos estão com medo, não sabendo a quem recorrer.

Episódios de violência se repetiam nos relatos, narrados sobretudo por mulheres. E, ao mesmo tempo em que elas os contavam, expressavam também uma grande surpresa por conhecer um lugar em que podiam falar sobre essas violências vividas. Saímos da reunião com o coração apertado por ouvir as vozes de quem carrega tanto sofrimento gerado por violências sociais que se repetem. A morte de um filho não é apenas uma fatalidade da vida, o risco de repetição da violência está a espreita e, a qualquer momento, ela pode se repetir com outro membro da família ou consigo mesmo, simplesmente porque estas populações são o "alvo". As pessoas têm muita consciência disso. Muita consciência da desigualdade social, de seu lugar no mundo e das poucas possibilidades que este mundo lhes oferece.

Mas também saímos com uma esperança de que é possível lutar e com uma agenda repleta de ações que serão desenvolvidas entre nós: técnicos, atendidos e ativistas, que aqui nada mais são que todas as pessoas que estão "na luta”. (Registro de caderno de campo )

O que venho observando nesses encontros é, então, a desestabilização das hierarquias e das categorias impostas pela forma como se organizam as políticas sociais, além da partilha e do fortalecimento de discursos que começam a estabelecer uma relação mais metonímica entre estes técnicos, ativistas e pessoas atendidas. Nesses lugares, faz-se um esforço para que tais categorias "desapareçam", para que seja possível construir uma ideia de "nós". Um "nós" forjado no reconhecimento a partir da identidade racial, de classe e de gênero, bem como do sofrimento gerado por violências sociais - cujo maior protagonista é o Estado - que recaem sobre a população periférica. Isto é, uma gramática do sofrimento mobilizada para produzir reconhecimento e lutas.

Neste capítulo, busquei apresentar o processo de implementação do Plano Juventude Viva na zona sul. Para isso, expus alguns elementos que estruturam a política de juventude documentos normativos, leis, instâncias burocráticas, categorias - sobre os quais se sustentam 
o Plano. Tais elementos propõem uma ação do Estado que procura fundamentar-se na participação democrática e no fortalecimento da ideia de juventude como "sujeito de direitos". Além disso, outro aspecto importante foi o de ressaltar o quanto o Plano Juventude Viva se constitui, ao menos em partes, na ideia de que o Estado reproduz um violência institucional pautada no racismo. E, se não se propõe a enfrentar essa violência, ao menos visa "preveni-la".

No entanto, quando se observa a sua implementação, esses princípios se esvaem na maneira como o Estado se apresenta na periferia: impondo-se de forma hierarquizada a partir de omissões ou de práticas normativas e violentas. Retorna-se ao pressuposto de que a exclusão e a violência são responsabilidades individuais e, assim, seriam necessárias políticas que acompanhem os sujeitos e suas famílias rumo à "inclusão social", disponível a partir do acesso a instituições e serviços públicos que constituem o campo da "gestão social".

No entanto, a proposta de constituição de um comitê para a implementação democrática do Plano, mesmo que não tenha sido eficaz ao que inicialmente se propunha, gerou um efeito talvez não esperado. Permitiu a articulação dos sujeitos, deste território já fértil em atuação política, que nas últimas décadas começavam a forjar um discurso sobre identidade racial e sobre a condição "periférica". Tal articulação sugere uma desestabilização da forma como o Estado se organiza nestas margens.

O Plano Juventude Viva teve como um de seus principais efeitos, ou talvez reações, a contribuição para o surgimento de novos ativistas e para o fortalecimento de discursos e práticas locais que começam a romper com hierarquias, categorias e segmentações impostas pela própria forma de organização estatal. Enfim, esta ação do Estado serviu para fortalecer uma luta que volta-se contra ele mesmo. 


\section{Considerações Finais}

Chego ao final deste trabalho provavelmente com mais perguntas do que iniciei. Do emaranhado destas margens busquei me desenrolar, pois dele faço parte e seus nós me constituem. Mais do que grandes conclusões, creio que tenha conseguido puxar alguns fios que me permitiram olhar com outros olhos e compreender melhor "minha casa", para usar os termos de Marylin Strathern (Strathern, 2014) sobre se fazer antropologia a partir do que lhe é familiar.

Um destes fios, foi exatamente problematizar a ideia, por mim tantas vezes também reproduzida, de que o Estado não está presente de forma suficiente na periferia. Certamente não está como nós, ativistas e acadêmicos comprometidos com uma sociedade mais justa e democrática, desejaríamos que estivesse. Isto é, um poder público capaz de garantir direitos sociais e proteção da população a partir de práticas e discursos verdadeiramente democráticos.

De fato, se observarmos a paisagem destes territórios veremos grandes escolas públicas que se destacam, por seu tamanho e arquitetura, das pequenas casas ao seu redor nos bairros mais afastados, diversos conjuntos habitacionais com grandes placas do governo, inúmeros equipamentos de assistência social e saúde, além da presença ostensiva da polícia.

Mas além deste aspecto observável a olho nu de sua presença, o que tentei sustentar neste trabalho é a presença não tão evidente assim, a forma transparente deste poder. Ou seja, a forma de organização do poder que rege normas e relações no interior destes equipamentos, transbordando, inclusive, para além de seus limites.

Assim busquei mobilizar referencias teóricas que definissem o Estado não como uma entidade ou bloco monolítico com limites bem delineados e impermeáveis funcionando pela lógica racional burocrática, mas sim que o entendessem como uma forma de poder que se impõem hierarquicamente, esquadrinhando territórios, segmentando, categorizando, normatizando e controlando sujeitos e relações (Hoffman, 2011).

Minha intensão foi afirmar que tal forma de poder se capilarizou pela periferia incorporando à sua estrutura movimentos sociais, instituições e sujeitos. Sobretudo a partir da década de 90 com a "entrada subalterna" da periferia à política a partir da execução de políticas sociais (Feltran, 2010).

Seguindo a argumentação de diversos autores, afirmo que a ampliação das políticas sociais a partir de "convênios" com a sociedade civil, motivou uma multiplicação de instituições sociais compondo o que muitos autores denominam de "gestão social". Minha 
pesquisa foi olhar para este campo, onde também me constituí como profissional e ativista, e que aqui chamo de margens do Estado (Das e Poole, 2004), pois defendi que se trata da "ponta" das políticas sociais, forjadas em outros setores e âmbitos governamentais envolvendo uma infinidade de documentos normativos, legislações, instâncias de gestão e protocolos de execução. Defendi que são nestas margens onde o Estado produz e reproduz gerando uma multiplicidade de efeitos, dentre eles violências sociais, mas também resistências.

E um dos efeitos desta ampliação do campo da gestão social que tentei demonstrar foi não apenas o de enfraquecer e institucionalizar os movimentos sociais, mas criar uma rede de ofertas de trabalho e de construção de carreiras profissionais que absorveu uma grande quantidade de moradores da periferia. Sobretudo aqueles que tiveram acesso à ampliação da educação e à programas de acesso à universidade.

Surgem então os técnicos das políticas sociais: psicólogos, assistentes sociais, educadores, etc. Nestas instituições e serviços sociais, tais técnicos estabelecem relações hierarquicamente e burocraticamente definidas com outros moradores da periferia que são categorizados como: "usuários", "público-alvo", "atendidos", etc. Categorias estas que são acompanhadas de desqualificação ou estigma, como sujeitos "vulneráveis", "perigosos" ou “incapazes” de dar conta de sua própria vida e relações (Sarti, 2008).

Procurei demonstrar como estas políticas sociais, apesar de se constituírem a partir de princípios ligados aos direitos humanos, tinham como propostas ações que responsabilizariam os sujeitos com relação aos problemas sociais, no caso a "exclusão social" (Saliba, 2006). Assim, segundo tais políticas, a partir de ações que normatizassem estes sujeitos e suas famílias, consequentemente, haveria a “inclusão social”. Inclusão social esta entendida como a inserção na malha de serviços públicos e no mercado de trabalho. E aqui vale ressaltar, todos precários.

As políticas sociais, e no caso das medidas socioeducativas, seriam elaboradas em outras instâncias do Estado e aterrizariam na periferia a partir destas instituições executoras (ONGs) com um conjunto de protocolos e diretrizes que orientariam a "inclusão destes jovens" em uma rede social que estaria de "portar abertas" para recebe-los. Mas o contexto de exclusão social que "os levou à infração" continua se reproduzindo fazendo com que nem equipamentos públicos, nem mercado de trabalho queiram estes sujeitos marcados pela raça, pobreza e agora, mais ainda, pelo estigma do "bandido" (Feltran, 2010). Assim, jovens e técnicos encontrariam uma contradição na execução desta política na "ponta" por falta de um contexto que, de fato, favorecesse a "inclusão". E frente à tal contradição alguns técnicos, 
para não restringir suas ações a procedimentos meramente burocrático, no cotidiano realizam um malabarismo criativo buscando formas alternativas de atendimento mais significativas e conectadas com suas visões de mundo.

A partir do MSE Capão II procurei expor tais agenciamentos criativos. Alternativas estas que foram sendo construídas a partir de um campo discursivo local e mobilizado por sujeitos que estão em interface com este campo institucional, mas não necessariamente institucionalizados. Sujeito, discursos e práticas ligadas à coletivos da região que vão se constituindo a partir dos marcadores sociais da diferença, sobretudo raça, classe e gênero. Tentei argumentar que trata-se de um processo de construção de identidade que permite o reconhecimento dos sujeitos marcados pela experiência do racismo, da pobreza e da violência de gênero no contexto "periférico". Violências sociais (Kleinman, 2000) estas cuja reprodução não se restringiria às relações interpessoais, mas contaria com dispositivos institucionais que garantem sua constante atualização. As políticas sociais constituiriam também tais dispositivos.

Assim o sofrimento gerado por violências sociais forjaria uma gramática moral (Moutinho, 2012; Sarti, 2011) que permite o reconhecimento, a construção de uma noção de um "nós". Reconhecimento este que começa a sustentar lutas que buscam explicitar e enfrentar estas violências institucionalizadas, como a denominada luta contra o "genocídio da população negra e pobre" que envolve cada vez mais ativistas e coletivos da região buscando denunciar o racismo de Estado (Foucault, 2002).

Minha intenção foi apresentar este processo da forma que eu compreendo e de como o campo se apresentou para mim na pesquisa, ou seja, a partir do surgimento e ações do Comitê Juventude e Resistência. Bem como os discursos por ele disseminados - discursos estes, por sua vez, influenciados por outros ativistas e coletivos - por meio de relações estabelecidas horizontalmente na região que passaram a influenciar alguns profissionais das políticas sociais, sobretudo os técnicos de medida socioeducativa do MSE Capão II.

Desta articulação, que não apenas observei, mas da qual faço parte, vem surgindo ações que desestabilizam a hierarquia das relações e categorias que enquadram os sujeitos e por meio das quais a política se realiza: "ténicos", "usuários", "atendimento", "relatórios", etc. Permitindo espaços de encontro e fala onde os sujeitos deslocam tais categorias construindo relações mais horizontais. Espaços estes onde "usuários" e "técnicos" se reconhecem por sua condição racial e de gênero, de pertencimento à periferia e de sim vulnerabilidade, mas esta relacionada à violência do Estado. Assim a ideia de que "somos 
todos negros e pobres submetidos ao racismo de Estado" construiria solidariedades e possibilidades de luta.

É isso que percebo na aproximação entre Comitê Juventude Resistência e MSE Capão II, isto é, ativistas, técnicos e "atendidos" construindo novas práticas, relação e discursos que visam uma auto-organização para enfrentamento do "racismo de Estado". Organização esta ainda muito frágil e com reduzidas propostas estratégicas.

São novas práticas, relações e discursos que embora não sejam capazes de influenciar outras dimensões hierárquicas - instituições, coordenadorias, documentos normativos, judiciário, etc - apresentam-se como experiências a partir das quais os sujeitos passam a dar sentido ao seu próprio sofrimento, reconhecendo-se como vítima, e percebendo que não estão sozinhos. 


\section{Referências Bibliográficas}

BAENINGER, Rosana. Crescimento da População na Região Metropolitana de São Paulo: desconstruindo mitos do século XX. In São Paulo: novos percursos e atores (sociedade, cultura e política)/ org. Lúcio Kowarick e Eduardo Marques. São Paulo: Ed. 34, 2011.

BEVILAQUA, Ciméia e Leirner, Piero C. Notas sobre a análise antropológica de setores do Estado brasileiro. Revista de Antropologia, São Paulo, USP, 2000, V. 43 no 2.

ButLER, Judith. Quadros de Guerra. Civilização Brasileira, 2015.

CALDEIRA, Teresa P. do R. O rap e a cidade: reconfigurando a cidade em São Paulo. In São Paulo: novos percursos e atores (sociedade, cultura e política)/ org. Lúcio Kowarick e Eduardo Marques, São Paulo: Ed. 34, 2011.

CARRIL, Lourdes. Quilombo, Favela e Senzala. Annablume, 2006

CASTRO, João Paulo M e. A construção de políticas públicas para a juventude: novas moralidades de gestão de segmentos sociais. In Revista de Antropologia, São Paulo, 2012, vol. 55(2).

CASTRO, Jorge A. de; AQUINO, Luseni M. C; ANDRADE, Carla C. de. Juventude e Políticas Sociais no Brasil. Brasília: IPEA, 2009

COELHO, Maria N. G. O Movimento Sindical Metalúrgico na Zona Sul de São Paulo: 1974 a 2000. Tese apresentada ao Departamento de História da Faculdade de Filosofia, Letras e Ciências Humanas da Universidade de São Paulo, 2007

CORTI, Ana Paula; Souza, Raquel. Diálogos com o mundo juvenil: subsídios para educadores. São Paulo: Ação Educativa, 2003

\section{D'ANDREA, Tiaraju P. A Formação dos Sujeitos Periféricos: Cultura e Política na}

Periferia de São Paulo. Tese apresentada ao Departamento de Sociologia da Universidade de São Paulo, 2013

DAS, Veena. O ato de testemunhar: violência, gênero e subjetividade. Cadernos Pagu, n.37, pp.9-41, 2011

Life and Words: Violence and the descent into the ordinary. Berkeley/Los Angeles: University of California Press, 2007. Fronteiras, violência e o trabalho do tempo: alguns temas wittgensteinianos. Revista Brasileira de Ciências Sociais, v.14, n.40, pp. 3142, 1999.

DAS, Veena; POOLE, Deborah. El estado y sus márgenes. Etnografías comparadas in Cuadernos de Antropología Social No 27, pp. 19-52, 2008. 
DELEUZE, Gilles; GUATTARI, Félix. Mil platôs - capitalismo c esquizofrenia, vol. 5, São Paulo: Ed. 34, 1997

DOUGLAS, Mary. Pureza e Perigo. 2.ed. - São Paulo: Perspectiva, 2012

FASSIN, Didier. Compassion and Repression: The Moral Economy of Immigration Policies in France in Cultural Anthropology, University of Paris North-Ecole des Hautes E'tudes en Sciences Sociales, 2005.

FELTRAN, Gabriel de S. "Jovens em conflito com a lei" in Revista de Antropologia Social dos Alunos do PPGAS-UFSCar, v.3, n.1, jan.-jun., p.259-267, 2011.

Fronteiras de tensão: um estudo sobre política e violência nas

periferias de São Paulo. Tese de Doutorado. Instituto de Filosofia e Ciências Humanas Universidade Estadual de Campinas. Campinas: 2008.

- "Periferia, direito e diferenças nota de uma etnografia urbana" in

Revista de Antropologia - USP. v. 53(2), 2010.

FOUCAULT, Michel. Aula de 17 de Março de 1976 in Em Defesa da Sociedade. São Paulo: Martim Fontes, 2002.

GREGORI, Maria Filomena. Viração: experiências de meninos nas ruas. São Paulo: Companhia das Letras, 2000

HOFFMAN, Danny. The War Machines: Young Men and Violence in Sierra Leone and Liberia. Durham, NC: Duke University Press, 2011.

KLEINMAN, Arthur. The Violences of everyday life: the multiple forms and dinamics of social violence in DAS, Veena; KLEINMAN, Arthur; RAMPHELE, Mamphela;

REYNOLDS, Pamela. Violence and Subjectivity. University of California Press, 2000

KOWARICK, Lúcio. Vive rem risco: sobre a vulnerabilidade socioeconomica e civil. São Paulo: E. 34, 2009

LEIRNER, Piero C. A Formação do Estado em uma Perspectiva Antropológica. Estudos Históricos, Rio de Janeiro, n.32, 2003.

LEITE, Vanessa. Sexualidade adolescente como direito? A visão de formuladores de políticas públicas. Rio de Janeiro: EdUERJ, 2013.

LIMA, Antonio C. de Souza. Sobre Gestar e Gerir a Desigualdade: pontos de investigação e diálogo in Gestar e Gerir: Estudos para uma antropologia da administração pública no Brasil. Antonio Carlos de Souza Lima (org.). Rio de Janeiro: Relume Dumará. Núcleo de 
Antropologia Política, UFRJ. 2002

MARQUES, Eduardo. Redes sociais, segregação e pobreza em São Paulo. São Paulo Editora Unesp; Centro de Estudos da Metrópole - 2010

MIAGUSKO, Edson Mutirão aotogestionário e o contexto da experiência democrática revisitado. Caderno CRH, Salvador, v.24, n. 61, Jan./Abr 2011

MIRÁGLIA, Paula. Cosmologia da Violência: entre a regra e a excessão - uma etnografia da cidade de São Paulo. Série Produção Acadêmica Premiada. São Paulo, 2010.

Rituais da Violência: a Febem como espaço do medo em São Paulo. Dissertação de Mestrado defendida no Departamento de Antropologia Social da Universidade de São Paulo, 2001.

MOUTINHO, Laura . Sobre danos, dores e reparações: The Moral Regenaration Movement controvérsias morais e tensões religiosas na ordem democrática sul-africana. In: Wilson Trajano Filho. (Org.). Travessias antropológicas: estudos em contextos africanos. Brasília: ABA, 2012, pp, $275 \backslash 296$.

MOUTINHO, Laura. Razão, “cor”e desejo: uma análise comparative sobre relacionamentos afetivos-sexuais “inter-raciais” no Brasil e na África do Sul. São Paulo: Unesp, 2004

MOREIRA, Jacqueline de O. M.; ALBUQUERQUE, Bruna S. de; ROCHA, Bianca, F.; ROCHA, Paula M; VASCONCELOS. Plano Individual de Atendimento (PIA) na perspectiva dos técnicos da semiliberdade in Serviço Social e Saúde, São Paulo, n. 122, p. 341-356, abr./jun. 2015

NASCIMENTO, Érica P. É tudo nosso! Produção cultural na periferia paulistana. Tese apresentada ao Programa de Pós-Graduação em Antropologia Social da Faculdade de Filosofia, Letras e Ciências Humanas da Universidade de São Paulo, 2011.

PAULA, Liana de. Liberdade Assistida: Punição e Cidadania na Cidade de São Paulo. Tese apresentada ao Programa de Pós-Graduação em Sociologia do Departamento de Sociologia da Faculdade de Filosofia, Letras e Ciências Humanas da Universidade de São Paulo, São Paulo: 2011.

RIZZINI, Irene. O Século Perdido: Raízes Históricas das Políticas Públicas para Infância no Brasil. Rio de Janeiro: Petrobrás-BR. Ministério da Cultura. USU Ed. Universitária. Amais, 1997

SALES, Mione Apolinário. (In) Visibilidade Perversa: adolescentes infratores como metáfora da violência. Tese apresentada ao Programa de pós-graduação em Sociologia do 
Departamento de Sociologia da Faculdade de Filosofia, Letras e Ciências Humanas da Universidade de São Paulo. São Paulo: 2006

SARTI, Cynthia A. A vítima como figura contemporânea. Caderno CRH. Salvador, v. 24, n. 61, p. 51-61, 2011.

SARTI, Cynthia A. A Família como espelho. Campinas, Editora Autores Associados, 1996.

SARTI, Cyntia A. Famílias enredadas in Famílias: redes, laços e políticas públicas.

ACOSTA, Ana Rojas; VITALE, Maria Amália Faller (Org.). São Paulo: Cortez/Instituto de Estudos Especiais/PUC-SP, 2008

SALIBA, Maurício G. O olho do poder: Análise crítica da proposta educativa do estatuto da criança e do adolescente. Editora Unesp: 2006

SECRETARIA-GERAL DA PRESIDÊNCIA DA REPÚBLICA, Guia de Políticas Públicas de Juventude Brasília: 2006.

SILVA, Enid R. A.; ANDRADE, Carla C. A Política Nacional de Juventude: avanços e dificuldades. In Juventude e Políticas Sociais no Brasil. Orgs: Castro, Jorge A.; Aquino, Luseni M. C. de; Andrade, Carla C. de - Brasília: IPEA 2009.

SPOSITO, M. P. . Juventude e Educação: interações entre educação escolar e a educação nãoformal. Educação e Realidade, v. 33, p. 83-97, 2008.

STRATHERN, Marilyn. Os Limites da autoantropolia, in Efeito Etnográfico, 2014 Cosac Naify

TEIXEIRA, Alessandra. Construir a Delinquência, Articular a Criminalidade: um estudo sobre a gestão dos ilegalismos na cidade de São Paulo. Tese apresentada ao Programa de pós-graduação em Sociologia do Departamento de Sociologia da Faculdade de Filosofia, Letras e Ciências Humanas da Universidade de São Paulo. São Paulo, 2012

TELLES, Vera da S. Prospectando a cidade a partir de suas margens: notas inconclusas sobre uma experiência etnográfica in Contemporânea, v. 3, n. 2, Dez. 2013

TELLES, Vera da S.; CABANES, Robert (org). Nas tramas da cidade : trajetórias urbanas e seus territórios / São Paulo : Associação Editorial Humanitas, 2006.

VIANNA, Adriana de R. B. Direitos, moralidades e desigualdades: considerações a partir de processos de guarda de crianças in Antropologia e Direitos Humanos 3, Prêmio ABA/FORD/ Roberto Kant de Lima (Organizador) — Niterói : EdUFF, 2001.

O mal que se adivinha: Polícia e Menoridade no Rio de Janeiro (1910-1920). Rio de Janeiro: Arquivo Nacional. 1999

WACQUANT, Loïc J.D. Corpo e Alma: Notas Etnográficas de um Aprendiz de Boxe. Rio de Janeiro: Relume Dumará, 2002 
A "reforma" da assistência social para vigiar e punir. In Punir os pobres: a nova gestão da miséria nos Estados Unidos. Rio de Janeiro: F. Bastos, 2001, Revan, 2003.

WOORTMANN, K \& WOORTMANN, E. Monoparentalidade e chefia feminina. Conceitos, contextos e circunstâncias. Apresentado no pré-evento Mulheres Chefes de Família: crescimento, diversidade e políticas. Ouro Preto, MG, 2002 